UNIVERSIDADE DE SÃO PAULO

FACULDADE DE FILOSOFIA, LETRAS E CIÊNCIAS HUMANAS

DEPARTAMENTO DE GEOGRAFIA

PROGRAMA DE PÓS-GRADUAÇÃO EM GEOGRAFIA HUMANA

O USO DO TERRITÓRIO CEARENSE PELA EDUCAÇÃO TÉCNICA PROFISSIONAL DE NÍVEL MÉDIO INTEGRADO E AS NOVAS DEMANDAS TERRITORIAIS

\author{
Versão Corrigida
}

São Paulo

2018 
JACQUELINE RODRIGUES MORAES

\title{
O USO DO TERRITÓRIO CEARENSE PELA EDUCAÇÃO TÉCNICA PROFISSIONAL DE NÍVEL MÉDIO INTEGRADO E AS NOVAS DEMANDAS TERRITORIAIS
}

\author{
Tese apresentada junto ao Programa de \\ Pós-Graduação em Geografia Humana \\ da Faculdade de Filosofia, Letras \\ Ciências Humanas da Universidade de \\ São Paulo. \\ Área de Concentração: Geografia \\ Humana
}

Orientadora: Profa. Dra. Amalia Inés Geraiges de Lemos

\section{São Paulo}

2018 
Autorizo a reprodução parcial ou total desta obra, para fins acadêmicos, desde que citada a fonte.

Catalogação na Publicação

Serviço de Biblioteca e Documentação

Faculdade de Filosofia, Letras e Ciências Humanas da Universidade de São Paulo

M827 Moraes, Jacqueline PROFISSIONAL DE NÍVEL MÉDIO INTEGRADO E AS NOVAS

Moru DEMANDAS TERRITORIAIS / Jacqueline Moraes; orientador Amalia Inés Geraiges Lemos. - são Paulo, 2017.

$264 \mathrm{f}$.

Tese (Doutorado) - Faculdade de Filosofia, Letras e Ciências Humanas da Universidade de São Paulo. Departamento de Geografia. Área de concentração: Geografia Humana.

1. Espaço Geográfico. 2. Território. 3. Bducação. I Lemos, Amalia Inés Geraiges, orient. II. Título. 


\section{ENTREGA DO EXEMPLAR CORRIGIDO DA DISSERTACC̃̃O/TESE}

Termo de Ciência e Concordância do (a) orientador (a)

Nome do (a) aluno (a): JACQUELINE RODRIGUES MORAES

Data da defesa: 15/12/2017

Nome do Prof. (a) orientador (a): AMALIA INÉS GERAIGES LEMOS

Nos termos da legislação vigente, declaro ESTAR CIENTE do conteúdo deste EXEMPLAR CORRIGIDO elaborado em atenção às sugestões dos membros da comissão Julgadora na sessão de defesa do trabalho, manifestando-me plenamente favorável ao seu encaminhamento e publicação no Portal Digital de Teses da USP.

São Paulo, 09/05/2019

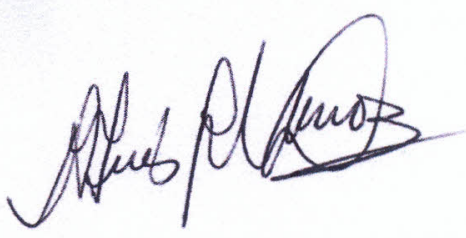

(Assinatura do (a) orientador (a)

Departamento de Geografia da USP FFLCH-Faculdade de Filosofia, Letras e Ciências Humanas Av. Prof Lineu Prestes, 338 - Cidade Universitária São Paulo - SP CEP: 05508-000 
MORAES, Jacqueline Rodrigues. O USO DO TERRITÓRIO CEARENSE PELA EDUCAÇÃOO TÉCNICA PROFISSIONAL DE NÍVEL MÉDIO INTEGRADO E AS NOVAS DEMANDAS TERRITORIAIS. Tese apresentada à Faculdade de Faculdade de Filosofia, Letras Ciências Humanas da Universidade de São Paulo para obtenção do título de Doutora em Geografia Humana.

Aprovada em:

Banca Examinadora:

Profa. Dra. Instituição:

Julgamento: Assinatura:

Profa. Dra. Instituição:

Julgamento: Assinatura:

Prof. Dr. Instituição:

Julgamento: Assinatura:

Prof. Dr. Instituição:

Julgamento: Assinatura:

Prof. Dr. Instituição:

Julgamento: Assinatura: 
À Sarah, Douglas, David e Luiza. Vocês me ensinaram e me fizeram vivenciar os verdadeiros sentidos do amor. 
"A educação corrente e formal, simplificadora das realidades do mundo, subordinada à lógica dos negócios, subserviente às noções de sucesso, ensina um humanismo sem coragem, mais destinado a ser um corpo de doutrina independente do mundo real que nos cerca, condenado a ser um humanismo silente, ultrapassado, incapaz de atingir uma visão sintética das coisas que existem, quando o humanismo verdadeiro tem de ser constantemente renovado, para não ser conformista e poder dar resposta às aspirações efetivas da sociedade, necessárias ao trabalho permanente de recomposição do homem livre, para que ele se ponha à altura do seu tempo histórico"

Milton Santos. 


\section{Agradecimentos}

Os encontros fazem parte da vida, o entrelaçar de pessoas e sentimentos se fazem sempre presente em nós em diferentes momentos e espaços dessa aventura que é viver, pois esta é um aprender e ensinar a cada dia. Nesse processo nos deparamos com muitas pessoas que, sem dúvida, nos dão suporte para nos tornarmos quem somos.

São essas pessoas que nos ajudam a trilhar caminhos, fazer escolhas e contribuem para a realização de sonhos e objetivos.

Cada um com sua forma de ver o mundo e nele viver, cada um a seu modo e sua maneira ajudaram-me a compreender coisas que hoje considero muito mais edificantes e importantes: perpassando o pessoal, até o profissional.

Agradecer é uma forma de expressar reconhecimento. E, antes de começalo já quero me desculpar com aquelas pessoas que involuntariamente, possam passar despercebidos e não serem mencionadas nessa seção.

Assim, estendo os meus mais sinceros agradecimentos:

Aos meus pais, David Moraes e Luiza Moraes que me dedicaram todo amor e cuidado para que eu pudesse caminhar e seguir meus sonhos.

Ao meu companheiro, amigo, esposo Francisco de Assis Sampaio (Douglas) que sempre me apoio com todo amor e me ajudou a atravessar mais essa etapa tão cara e importante para mim.

À minha filha Sarah Moraes, que deu outro sentido a minha vida, me ensinando o sentido do amor de mãe.

À minha irmã amada Ana Marta Moraes, meu cunhado Valdeci Alves e minha sobrinha Vanessa Moraes pela acolhida calorosa, pelo carinho, dedicação, risos e companhia tão gratificante.

Aos meus irmãos Renê, Ernesto, Raniere, Elano, Reginaldo, Fernando e minhas cunhadas Joana, Tarciane, Camila, Rose, Maria de Jesus e Socorro, obrigado pelo carinho e pelas palavras de incentivo que sempre dirigem a mim.

À todos os meus sobrinhos e sobrinhas que me transmitem alegria e crença num futuro bom. 
Ao Allan, Joveline, July e Emanuel por me proporcionar a alegria de ter Isabela, Anabela e Ingrid sempre por perto, alegrando minha vida.

A Samila e Cauan pela companhia e cuidado para comigo.

Agradeço imensamente e especialmente as minhas duas professoras e orientadoras, dádivas preciosas do destino, Maria Adélia Aparecida de Souza e Amalia Inés Geraiges Lemos, mestras e intelectuais que me proporcionaram enxergar o espaço geográfico a partir de uma nova geografia, por meio das orientações, críticas, sugestões e leitura dos meus textos. Instigando-me a avançar sempre na direção de um conhecimento mais humano, pertinente e inovador sobre as possibilidades do mundo. Vocês sempre terão meu carinho, minha admiração e minha eterna gratidão.

À amiga Carminha, uma irmã que a vida me deu, obrigada por sempre estar do meu lado durante o doutorado e pelas inúmeras vezes que me ajudou na da feitura da tese, que me ouviu nas horas de desânimo e, sobretudo, pela amizade sincera.

Às queridas amigas Luzia, Flavia, Gil, Teté, Daiane Silva, Dayane Paiva, Carin, Mait, Camila, Larisse, Carmem Lúcia, Livinha e Fran pela presença amiga e companhia sempre leve. Obrigada pela amizade de longa data e por serem grandes incentivadoras dos meus projetos.

À amiga Gil Rodrigues pela grande amizade e interesse em ajudar-me nas pesquisas geográficas.

À amiga Leidiane pelo apoio e carinho que sempre me dedicou na minha estadia em São Paulo.

À amiga e colega de doutorado Alessandra, um presente que a vida me trouxe, obrigada pela disponibilidade em me ajudar e apoiar sempre que precisei.

À os colegas do grupo de pesquisas e estudos da USP, coordenado pela professora Maria Adélia, particularmente a Markelly, pela ajuda na cartografia dos dados da pesquisa.

Aos professores Francisco Capuano Scarlato, Sônia Castelar, Luiz Cruz Lima e Cassiano Caon Amorim por aceitarem participar da banca de qualificação e defesa.

Aos amigos queridos Rapper Pirata e Marcielyo, que compartilham ricas reflexões sobre a Política, no cotidiano paulistano. 
Aos funcionários da Secretaria de Pós Graduação em Geografia, da FFCHL. Ao ex-governador do estado do Ceará Cid Ferreira Gomes, a Coordenadora da Educação Profissional de Nivel Medio, Jussara Batista, por gentilmente me concederem entrevista, proporcionando um aprofundamento do uso do território pela Educação Técnica de Nível Médio.

À Elaine Guinevere, pela tradução do resumo em inglês e pela correção ortográfica do relatoria da tese.

À Lourdes Lima pela disponibilidade em traduzir o resumo para o espanhol.

Aos diretores e coordenadores de escolas que me receberam e me auxiliaram nas questões pertinentes às EEEPs.

Por fim, agradeço a todos que de forma intelectual, técnica, pessoal ou afetiva, me ajudaram a desfrutar da satisfação de aprofundar o conhecimento do uso do território cearense pela educação técnica profissional de nível médio integrado e as novas demandas territoriais. 


\section{Resumo}

Esta pesquisa faz um estudo do uso do território pela Educação Profissional Técnica de Nível Médio Integrada no Estado do Ceará/ Brasil buscando compreendê-la, bem como sua funcionalidade, relacionadas à constituição do meio técnico-científicoinformacional. A reflexão se encaminha no sentido de abrir um diálogo acerca do uso do território no estado do Ceará, pela organização e condução do ensino médio técnico profissional integrado e a sua opção contemporânea. Busca-se entender os motivos que levam a sociedade de um estado com uma taxa de analfabetismo de 45,9\% (IBGE, 2010) e um ensino médio de baixa qualidade a se encaminhar para uma educação profissionalizante. Neste sentido questiona-se, que parâmetros estão sendo utilizados para a sua ampliação, uma vez que se torna evidente uma prática que considera determinados saberes técnicos? Em princípio, entende-se que a modalidade de Ensino Médio Técnico Profissional no estado do Ceará, está relacionada ao uso do território que impõe sua lógica à dinâmica do ensino em consonância com o período técnico-científico-informacional, criando demandas educacionais que ajudam a configurar o território que ganha novas formas-conteúdo e impõe novos comportamentos. Nessa dinâmica a educação se adequa ao meio geográfico, bem como exerce influência sobre sua configuração pelo o uso do território, criando e recriando novas demandas educacionais. O que resulta em demandas que geram conflitos entre $o$ ato de produzir e de viver demonstrando a contradição do mundo contemporâneo, que congrega uma ordem global e local. Desta forma, o uso do território pela educação técnica profissional cearense se constitui num uso corporativo território e pouco expressa o uso do espaço banal indispensável ainda para a sociedade cearense, pois grande parte dos investimentos destina-se a atender setores da economia global. Como forma de contribuir acrescenta-se que o debate em torno da educação como forma de sustentar arranjos, para o crescimento econômico no contexto de uma economia global, não torna a educação capaz de edificar outro tipo de economia produtiva, ao contrário, essa ideologia vista, aceita e aplicada, forma pessoas para se inserir no modelo de sociedade que a mesma educação busca modificar. Ressalta-se que essa proposta passa tanto pelo redirecionamento das politicas educacionais, quanto pelo projeto de sociedade que se deseja. Uma mudança na condução da educação técnica que tivesse como foco o homem em sua completude e sua interação com as demandas do espaço banal, poderia promover mudanças culturais e a partir delas, mudanças estruturais. Uma discussão teórica e política complexa, mas importante para a constituição de uma sociedade mais igualitária e consciente sobre a importância da educação para tornar isso possível.

Palavras-chave: Uso do território. Meio técnico-científico-informacional. Educação técnica profissional. Demandas territoriais. 


\begin{abstract}
This research accomplished a study on the use of the territory by Technical Education of Integrated Middle Level in the State of Ceará / Brazil, aiming at understanding it, as well as its functionality, related to the constitution of the technical-scientific-informational environment. This work opens a dialogue about the use of the territory in the state of Ceará, for the organization and conduction of integrated technical vocational secondary education and its contemporary option. We intend to understand the reasons that lead the society to a state of illiteracy rate of $45.9 \%$ (IBGE, 2010) and low-grade secondary education to move towards a vocational education. In this sense, one asks: what parameters are being used for its amplification, once a practice that considers certain technical knowledge becomes evident? In principle, it is understood that the modality of Technical Secondary Education in the state of Ceará is related to the use of the territory that imposes its logic on the dynamics of teaching, in harmony with the technical-scientificinformational period, creating educational demands, which help to configure the territory, which gains new forms-content and imposes new behaviors. In this dynamic, education is adapted to the geographical environment, as well as it exerts influence on its configuration by the use of the territory, creating and recreating new educational demands. This results in demands, generating conflicts between the act of producing and living. What reveals the contradiction of the contemporary world, which brings together a global and local order. In this way, the use of the territory by the professional technical education of Ceará is constituted in a territorial corporate use, and do not expresses much of the use of the banal space, still indispensable for the society of Ceará, since much of the investments are suposed to contribute to sectors of the global economy. In addiction. It is important to say that the debate about education, as a way of sustaining arrangements for economic growth in the context of a global economy, does not make education capable of building another kind of productive economy, on the contrary, it forms people to fit into the model of society that the same education seeks to modify. It should be emphasized that this proposal goes through both the redirection of educational policies and the desired social project. A change in the conduction of technical education that focus man in its completeness and its interaction with the demands of the banal space, could promote cultural changes and, from them, structural changes. A complex theoretical and political discussion, central for the constitution of a more egalitarian and conscious society, on the importance of education, could make this possible.
\end{abstract}

Keywords: Territory use. Technical-scientific-informational medium. Professional technical education. Territorial claims. 


\section{Resumen}

Esta investigación desarrolla un estudio del uso del territorio por la Educación Profesional Técnica de la Enseñanza Media Integrada en el estado de Ceará/ Brasil buscando comprenderla, tal como su funcionalidad, relacionadas a la constitución del medio técnico-científico-informacional. La reflexión se halla al intentar un diálogo acerca del uso del territorio en el estado de Ceará, por la organización y conducción de la enseñanza media técnica profesional integrada y a su opción contemporánea. Se objetiva comprender los motivos que llevan a la sociedad de un estado con una tasa de analfabetismo del 45,9\% (IBGE, 2010) y una Enseñanza Media de baja calidad a dirigirse a la educación profesional. En este sentido se cuestiona: ¿Cuáles parámetros se están utilizando a su ampliación, ya que se evidencia una práctica que considera determinados saberes técnicos? Para empezar, se comprende que la modalidad de Enseñanza Media Técnica Profesional en el estado de Ceará, está relacionada al uso del territorio que impone su lógica a la dinámica de la enseñanza de acuerdo con el período técnico-científico-informacional, creando demandas educacionales que ayudan a configurar el territorio que adquiere nuevas formas y contenidos e impone nuevos comportamientos. En esta dinámica la educación se adecua al medio geográfico, tal como ejerce influencia sobre su configuración por el uso del territorio, creando y recreando nuevas demandas educacionales. Eso resulta en demandas que generan conflictos entre lo de producir y lo de vivir demostrando la contradicción del mundo contemporáneo, que congrega un orden global y local. Así pues, el uso del territorio por la educación técnica profesional cearense se constituye en el uso corporativo territorial y poco expresa el uso del espacio común aún indispensable a la sociedad cearense, pues gran parte de las inversiones se destina a atender sectores de la economía global. Se añade que el debate alrededor de la educación como paliativo al crecimiento económico en el contexto de una economía global, no vuelve la educación apta a edificar otro tipo de economía productiva, al revés, esa ideología aceptada y aplicada, forma personas a inserirse al modelo de sociedad que dicha educación se propone a cambiar. Se destaca que esa propuesta pasa tanto por la reconducción de las políticas educacionales, como por la sociedad que se desea. Un cambio en la conducción de la educación técnica que tenga como foco el hombre en su completitud y su integración con las demandas del espacio común, se podría ocasionar cambios culturales y a partir de estos, cambios estructurales. Un debate teórico y político complejo, pero relevante a la constitución de una sociedad más igualitaria y consciente de la importancia de la educación para hacerlo posible.

Palabras clave: Uso del territorio. Medio técnico-científico-informacional. Educación técnica profesional. Demandas territoriales. 


\section{Lista de siglas}

ADECE - A Agência de Desenvolvimento do Estado do Ceará

AID - Agency for Internacional Development

CEPAL - Comissão Econômica para a América Latina e o Caribe

CECITEC - Faculdade de Educação, Ciências e Letras dos Inhamuns

CIPP - Complexo Industrial e Portuário do Pecém

CNE - Conselho Nacional de Educação

CNCT - Catálogo Nacional de Cursos Técnicos

CONAC - Comissão Executiva Nacional de Avaliação do Catálogo Nacional de Cursos Técnicos

CONPEP - Comitê Nacional de Políticas de Educação Profissional e Tecnológica

CREDE - Coordenadoria Regional de Desenvolvimento da Educação da Educação

CSP - Companhia Siderúrgica do Pecém

DNOCS - Departamento Nacional de Obras Contra a Seca

ENEM - Exame Nacional do Ensino Médio

EIA-RIMA - Estudo e Relatório de Impacto Ambiental

EEEP - Escola Estadual de Educação Profissional

EPMI - Educação Técnica Profissional de Nível Médio Integrada ao Ensino Médio

EUROSTAT - Statistical Office of the European Communities

FAT - Fundo de Amparo ao Trabalhador

FUNDEB - Fundo de Manutenção e Desenvolvimento da Educação Básica e de Valorização dos Profissionais da Educação

FUNDEF - Fundo de Manutenção e Desenvolvimento do Ensino Fundamental e de Valorização do Magistério

FNDE - Fundo Nacional do Desenvolvimento da Educação 
FVS - Faculdades Vale do Rio Salgado

GN - Gás Natural

GNL - Gás Natural Liquefeito

HABITAR-BID - Programa Habitacional

IBGE - Instituto Brasileiro de Geografia e Estatística

IDEB - Índice de Desenvolvimento da Educação Básica

IFCE - Instituto Federal de Educação, Ciência e Tecnologia do Ceará

INEP - Instituto nacional de Estudos e Pesquisas Educacionais Anísio Teixeira

IPEA - Instituto de Pesquisa Econômica Aplicada

IPECE - Instituto de Pesquisa e Estratégia Econômica do Ceará

IPHAN - Instituto do Patrimônio Histórico e Artístico Nacional

IPLANCE - Fundação Instituto de Pesquisa e Informação do Ceará

LDB - Lei de Diretrizes e Bases da Educação Nacional

MEC - Ministério da Educação

METROFOR - Programa de Trens da Região Metropolitana de Fortaleza

PAC - Programa de Aceleração do Crescimento

PALOP - Países Africanos de Língua Oficial Portuguesa

PBF - Programa Bolsa Família

PCNs - Parâmetros Curriculares Nacionais

PIB - Produto Interno Bruto

PIFORAR - Projeto de Apoio ao Crescimento Econômico com Redução das Desigualdades e Sustentabilidade Ambiental do Estado do Ceará

PforR - Programa para Resultados

PLANFOR - Plano Nacional de Educação Profissional

PND - Plano Nacional de Desenvolvimento 
PNE - Plano Nacional de Educação

PNUD - Programa das Nações Unidas para o Desenvolvimento

PNQ - Plano Nacional de Qualificação

PPPs - Parcerias Público-Privadas

PROAGUA - Programa de Desenvolvimento Sustentável de Recursos Hídricos para o Semi-Árido Brasileiro

PROARES - Programa de Apoio às Reformas Sociais para o Desenvolvimento de Crianças e Adolescentes

PROASIS - Programa de Apoio ao Saneamento Integrado Sertão

PROCEAGRI - Programa Cearense de Agricultura Irrigada

PRODETUR - Programa de Ação para o Desenvolvimento do Turismo no Nordeste

PROGERIRH - Programa de Gerenciamento e Integração de Recursos Hídricos

PRONAF - Programa Nacional de Agricultura Familiar

PRONATEC - Programa Nacional de Acesso ao Ensino Técnico e Emprego

PROURB - Programa de Desenvolvimento Urbano e Gestão

SAEB - Sistema de Avaliação da Educação Básica

SANEAR - Programa de Infraestrutura em Saneamento do Estado do Ceará

SDR - Secretaria de Desenvolvimento Rural

SEDUC - Secretaria de Educação do Estado do Ceará

SEFAZ - Secretaria da Fazenda

SEAGRI - Secretaria de Agricultura e Desenvolvimento Rural

SENAC - Serviço Nacional de Aprendizagem Comercial

SENAI - Serviço Nacional de Aprendizagem Industrial

SENAR - Serviço Nacional de Aprendizagem Rural

SENAT - Serviço Nacional de Aprendizagem do Transporte

SEMTEC - Secretaria de Educação Média e Tecnológica 
SETEC - Secretaria de Educação Profissional e Tecnológica

SETUR - Secretaria do Turismo do Estado do Ceará

SIAP - Sistema Integrado de Acompanhamento de Programas

SPAECE - Sistema Permanente de Avaliação da Educação Básica do Ceará

TEO - Tecnologia Empresarial Odebrecht

TESE - Tecnologia Empresarial Socioeducacional

UECE - Universidade Estadual do Ceará

UFC - Universidade Federal do Ceará

UFRJ - Universidade Federal do Rio de Janeiro

UNESCO - Organização das Nações Unidas para a Educação, a Ciência e a Cultura

UNICEF - Fundo das Nações Unidas para a Infância

UNOPAR - Universidade Norte do Paraná

URCA - Universidade Regional do Cariri

USP - Universidade de São Paulo

UVA - Universidade Vale do Acaraú

VPRs - Vilas Produtivas Rurais 


\section{Lista de Mapas}

Mapa 1: Estado do Ceará: Escolas Estaduais de Educação Profissional por Município. 2017.

Mapa 2: Capitanias Hereditárias

51

Mapa 3: Estado do Ceará: Municípios que herdaram toponímia das Vilas instaladas no final do século XVIII.

Mapa 4: Estado do Ceará: Municípios com Centro Econômico e Porto na 66 primeira metade do século XIX.

Mapa 5: Estado do Ceará: Polos de Agricultura Irrigada. 2017.

Mapa 6: Transposição do Rio São Francisco.

Mapa 7: Estado do Ceará: Número de Empresas ou Organizações de Educação por Município. 2010.

Mapa 8: Estado do Ceará: Número de Empresas ou Organizações de Educação por Município. 2010.

Mapa 9: Estado do Ceará: Municípios selecionados pela pesquisa de tese por total de empresas industriais. 2012.

Mapa 10: Estado Ceará: Densidades técnicas e populacionais segundo a pesquisa de tese.

Mapa 11: Mesorregiões do Ceará

Mapa 12: Cidades da Mesorregião Noroeste Cearense: usos pelas EEEPs e potencialidades

Mapa 13: Cidades da Mesorregião Norte Cearense: usos do território pelas EEEPs.

Mapa 14: Mesorregião Jaguaribe: usos do território pelas EEEPs

Mapa 15: Mesorregião Sertões Cearenses.

Mapa 16: Mesorregião centro-sul cearense: usos do território pelas EEEPs.

Mapa 17: Mesorregião sul cearense: usos do território pelas EEEPs 


\section{Lista de Gráficos}

Gráfico 1: Número de matrículas na Educação Técnica de Nível Médio 116 Integrada de 2008 à 2014.

Gráfico 2: Número de cursos ofertados nas EEEPs

\section{Lista de quadros}

Quadro 1: Cursos Técnicos ofertados nas EEEPs no Ceará

Quadro 2: Vilas do Ceará no final do século XVIII, por data de instalação

Quadro 3: Iniciativas de ensino primário na Província do Ceará

Quadro 4: Principais centros econômicos do Ceará na primeira metade do século XIX.

Quadro 5: Cursos e Números de Cursos ofertados nas Escolas Profissionais Técnica de Nível Médio 


\section{Lista de tabelas}

Tabela 1: Estabelecimentos comerciais, segundo os setores econômicos e os gêneros de atividades - Ceará - 2007/2012.

Tabela 2- Desenvolvimento da Educação Profissional no Ceará, de 2008 à 2014.

Tabela 3: Indústria de transformação - Ceará - 2007/2012

Tabela 4: Empresas industriais - Região metropolitana de Fortaleza e municípios selecionados Ceará - 2007/2012

Tabela 5: Investimentos nas EEEPs

Tabela 6: Evolução do rendimento médio das famílias Brasil e Regiões

Tabela 7: Evolução do número de matrículas na educação profissional por dependência administrativa - Brasil 2008-2014.

Tabela 8 - Evolução da Educaçao profissional integrada no Ceará, 2008 a 2016

Tabela 9 - Oferta de matrículas nas EEEPs no Ceará. 2008 a 2016 


\section{Lista de Fotos}

Foto 1 - Os jesuítas e as primeiras iniciativas de educação no espaço geográfico brasileiro.

Foto 2: Liceu do Ceará

Foto 3: Escola Normal Pedro II - 1884

Foto 4: Complexo Industrial e Portuário do Pecém

Foto 5: Complexo Industrial e Portuário do Pecém/CE.

Foto 6: Complexo Industrial e Portuário do Pecém/CE.

Foto 6: Vista aérea - Complexo Industrial e Portuário do Pecém/CE.

Foto 7: Terminal Flexível de Regaseificação de Gás Natural Liquefeito

Foto 8: EEEP Guiomar Belchuior Aguiar - Cariré/CE

Foto 9 : EEEP Guiomar Belchior Aguiar - Biblioteca (Escola Padrão MEC)

Foto 10: EEEP Guiomar Belchior Aguiar - Auditório (Escola Padrão MEC

Foto 11: EEEP Guiomar Belchior Aguiar - Sala de aula (Escola Padrão MEC)

Foto12: Fachada da EEEP Dom Walfrido Teixeira Vieira - Antigo Liceu Sobral/CE (refuncionalizada para EEEP)

Foto 13: Pátio da EEEP Dom Walfrido Teixeira Vieira - Antigo Liceu Antigo 166 Liceu - Sobral/CE (refuncionalizada para EEEP) 
Foto 14: Fachada da EEEP Francisca Castro de Mesquita (readaptada 166 para EEEP)

Foto 15: EEEP Francisca Castro de Mesquita - Refeitório (readaptada 167 para EEEP)

Foto 16: EEEP Francisca Castro de Mesquita - Sala de aula (readaptada | 167 EEEP)

Foto 17: Igreja do Céu - Viçosa do Ceará

Foto 18: Sobral/Ceará

Foto 19: Fazenda de flores - Reijers: São Benedito/CE.

Foto 20: Fruticultura - Ibiapaba

Foto 21: Fruticultura - Ibiapaba

Foto 22: Fruticultura - Ibiapaba

Foto 23: Guaramiranga/CE

Foto 24: Museu Senzala Negro Liberto - Redenção 
AGRADECIMENTOS ................................................................. vi

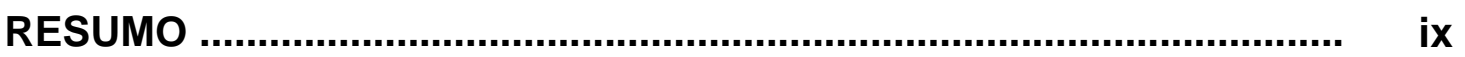

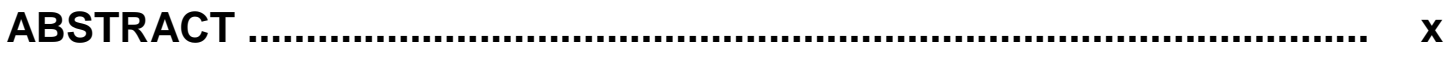

RESUMEN

LISTA DE SIGLAS …............................................................................ xii

LISTA DE MAPAS …….............................................................

LISTA DE GRÁFICOS …................................................................. $\quad$ xvii

LISTA DE QUADROS …................................................................... $\quad$ xvii

LISTA DE TABELAS …................................................................... $\quad$ xviii

LISTA DE FOTOS ……....................................................................

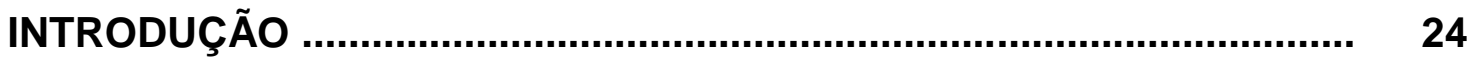

\section{PARTE I}

A CONSTITUIÇÃO DO TERRITÓRIO CEARENSE E A EDUCAÇÃO ........ 40

CAPITULO 1 - A PRESENÇA EUROPEIA NO BRASIL E NO CEARÁ E AS PRIMEIRAS INICIATIVAS DE EDUCAÇÃO NO TERRITÓRIO: DA PECUÁRIA A MODERNIDADE

Pressupostos da colonização: O domínio dos novos territórios

O território, seus habitantes e suas relações com o meio geográfico ......

A presença europeia no Brasil e no Ceará

As primeiras iniciativas de educação: contradições nos usos do território

CAPÍTULO 2 - MODERNIZAÇÃO, INDUSTRIALIZAÇÃO E O APOGEU DA EDUCAÇÃO PROFISSIONAL

Meio-técnico-científico, desenvolvimentismo e formação profissional.... 
Os novos usos e as novas demandas econômicas: a refuncionalização do ensino e o atendimento ao mercado globalizado.

PARTE II

GLOBALIZAÇÃO, MEIO-TECNICO-CIENTÍFICO-INFORMACIONAL E AS NOVAS DEMANDAS EDUCACIONAIS NO CEARÁ

CAPÍTULO 3 - O MEIO TÉCNICO-CIENTÍFICO-INFORMACIONAL E A EDUCAČÃO TÉCNICA NO CEARÁ: UMA DUPLA AÇÃO SIMULTÂNEA.

O Ceará no contexto do meio técnico-científico-informacional

A EPMI na totalidade

CAPÍTULO 4 - GLOBALIZAÇÃO, MEIO-TÉCNICO-CIENTÍFICOINFORMACIONAL E AS NOVAS DEMANDAS EDUCACIONAIS.

Os impactos do meio-técnico-científico-informacional nos usos do território cearense pela educação

\section{PARTE III}

AÇÕES E NORMATIZAÇÕES PARA A EDUCAÇÃO TÉCNICA PROFISSIONAL DE NÍVEL MÉDIO INTEGRADA E O USO DO TERRITÓRIO CEARENSE: AS CONTRADIÇÕES ENTRE O ATO DE PRODUZIR E VIVER E OUTRAS POSSIBILIDADES.

CAPÍTULO 5 - ESTADO, AÇÕES E NORMATIZAÇÕES PARA A EDUCAÇÃO TÉCNICA PROFISSIONAL INTEGRADA AO ENSINO MÉDIO.

Espaço banal: o espaço de todos e a oferta da educação profissional de nível médio

A opção pelas EEEPs: as demandas do mercado e os usos do território

CAPÍTULO 6: A CONDUÇÃO DA EDUCAÇÃO NO CEARÁ: ELEMENTOS PARA PENSAR UMA FORMAÇÃO HUMANISTA

A perspectiva geográfica sobre educação

Outras possibilidades e outros usos possíveis e necessários, do 196 território cearense? 
REFERÊNCIAS BIBLIOGRÁFICAS

ANEXOS 


\section{INTRODUÇÃO}

Esta pesquisa estuda o uso do território pela Educação Profissional Técnica de Nível Médio Integrada no Estado do Ceará/ Brasil buscando compreendê-la, bem como sua funcionalidade, relacionadas à constituição do meio técnico-científicoinformacional ${ }^{1}$.

A escolha do tema foi motivada principalmente pela importância atribuída à educação como forma de reflexão do mundo do presente, haja vista que é considerada um direito inalienável e a maneira mais eficaz de possibilitar o livre pensar.

Para sua operacionalização, a abordagem geográfica se encaminhou, partindo do conceito de espaço geográfico enquanto um sistema de objetos e sistema de ações, constituído historicamente mediante a intencionalidade dos diversos agentes (SANTOS, 2012).

Para a delimitação do objeto de estudo, recorre-se a Milton Santos (2011, p.14) e sua discussão acerca do estudo do território:

O que estudamos diante de um território, de um país? Deste país, por exemplo. São as transformações todas, seja qual for o período de sua história, transformações que se realizaram mediante ações econômicas, políticas, culturais que vão desembocar no território e nós estudamos o que? O território. Como se ele fosse um dado autônomo, razão do nosso total desprestígio (...). O que é que a geografia faz? É estudar todas essas ações, quando eu chego a qualquer país, o que eu estou estudando geografia? São todas as ações que se fizeram, no passado remoto ou recente, de todo tipo. $O$ que eu tenho que me preparar para fazer, é compreender de um lado as transformações que estão se dando, o impacto dessas transformações no espaço que nos compete estudar, mas também como as transformações feitas no espaço vão contribuir para que uma dada política possa ser possível, para que uma dada economia possa ser possível, para que uma dada sociedade possa ser possível, para que uma dada cultura seja possível, para que uma dada moral seja possível.

\footnotetext{
${ }^{1}$ Para Milton Santos, esse é "o meio geográfico do período atual, onde os objetos mais proeminentes são elaborados a partir dos mandamentos da ciência e se servem de uma técnica informacional da qual lhes vem o alto coeficiente de intencionalidade com que servem às diversas modalidades e às diversas etapas de produção" (SANTOS, 2012, p. 235).
} 
Portanto, o presente estudo utilizou-se de alguns conceitos e categorias fundamentais para a análise do uso do território, tomando como variável a educação, dentre eles estão: Espaço geográfico, Território usado - espaço geográfico como um conjunto indissociável, solidário e também contraditório de sistemas de objetos e sistemas de ações - Verticalidades e horizontalidades - à meditação sobre o que os objetos construídos pelo homem podem representar na transformação que se deseja da fisionomia do território no qual vivemos, tendo como resultado zonas luminosas e opacas; a força da solidariedade organizacional sobrepondo-se a solidariedade orgânica, onde as verticalidades tem maior incidência no território que as horizontalidades, tornando o espaço cada vez mais racional; as normas como o veículo de homegeneização técnica e organizacional; a face material da globalização refletida na expansão do meio técnico-científicoinformacional e seus reflexos no território cearense no que se refere a condução da educação, tendo como resultado a tecnificação da mesma; o Lugar como espaço do acontecer solidário, compreendido "como funcionalização do mundo" e ao mesmo tempo reflexo dele, sendo que "é por ele (lugar) que o mundo é percebido", espaço da resistência, sua relação lugar/mundo onde surgem as demandas das localidades e concomitante as ações para efetivá-las.

A reflexão se encaminha no sentido de abrir um diálogo acerca do uso do território no Estado do Ceará, pela organização e condução da educação básica, no que se refere ao ensino médio técnico profissional integrado, a partir de ações refuncionalizadas ${ }^{2}$.

Através da categoria território usado, e da variável educação técnica profissional, busca-se defender a tese de que o uso do território pela educação técnica profissional cearense se constitui num uso corporativo ${ }^{3}$ do território

\footnotetext{
${ }^{2}$ Segundo Corrêa (2011) o termo refuncionalização diz respeito às formas criadas em diferentes momentos, mas funcionalmente ativas. "A permanência de formas antigas refuncionalizadas se faz presente em toda parte, na cidade e no campo, em países antigos e novos" (CORRÊA, 2011, p.13). Antigas fábricas, muitas delas dedicadas à produção de tecidos que foram transformadas em hipermercados, museus, shopping centers ou outras ocupações são exemplos de formas refuncionalizas, bem como, ferrovias, quartéis, templos, casarões, entre outros, foram, em muitos casos, refuncionalizados para um número crescente de novas e antigas atividades consideradas mais eficazes.

${ }^{3}$ Relativo ao sistema político sob o qual as principais funções econômicas, tais como os bancos, as indústrias e a mão-de-obra são organizados e conduzidos por meio de corporações.
} 
pouco expressando o uso do espaço banal ${ }^{4}$, indispensável ainda para a sociedade cearense, visto que a maior parte dos investimentos são destinados para atender a setores da economia global, gerando conflitos entre o ato de produzir e de viver.

Uma vez que os usos hegemônicos do território predominam e trazem como consequência muitas contradições que passam a ser reveladas territorialmente, a partir da seletividade, concentração populacional, pelas desigualdades socioespaciais, ampliadas a cada dia neste atual período da história humana.

As escolas de formação técnica profissional são um exemplo dessas conexões, por ter sua criação destinada inicialmente à formação dos pobres e desvalidos no intuito de dar-Ihes um meio de sobrevivência e, para suprir as novas demandas que seriam criadas no território, fruto da expansão do capitalismo, da "capitalização" crescente das atividades e sua incidência nos países periféricos.

A seletividade socioespacial é um dado marcante, visto que esta surge nas localidades onde as demandas por mão de obra para determinadas tarefas passam a ter um papel relevante.

Durante os períodos do seu processo de refuncionalização, estas escolas foram sendo readaptadas, principalmente, para atender aos mais variados setores da economia na tentativa de suprir as demandas que foram sendo criadas a partir da instalação de novos objetos no espaço geográfico. Que em períodos diferentes, revela dentre outros aspectos, estreitas relações e conexões com a economia e concomitante, com as demandas que são criadas e recriadas para atender setores da produção, que maior exercem poder e influência de efetivar a transformação que se deseja na composição do território (SANTOS, 2008).

As transformações que se realizaram mediante as ações econômicas, políticas, culturais tem seus reflexos no território e empreendem a criação desses novos objetos, que demandam sucessivamente uma reorganização do espaço geográfico para sua funcionalização.

$\mathrm{Na}$ idealização da criação dessas escolas, há o indício da força da incidência dos agentes hegemônicos que selecionam o que vai ser difundido, mas como o espaço geográfico é sinônimo de espaço de todos, o seu uso nem sempre segue

\footnotetext{
${ }^{4} \mathrm{O}$ espaço banal é definido por Santos como o espaço de todos os homens, não importando suas diferenças sociais; é o espaço de todas as dimensões do acontecer, de todas as determinações da totalidade social [...] é o espaço de todos, todo o espaço" (SANTOS, 200, p. 104).
} 
uma lógica pensada e planejada por um processo de conteúdo ideológico globalizador, pois há nele a resistência que se expressa através do território usado. Por isso, seu uso pela educação profissional demonstra a contradição do mundo contemporâneo, que congrega uma ordem global e local, fortalecendo demandas que geram conflitos entre $o$ ato de produzir e de viver.

É nesse entendimento que a pesquisa, procura demonstrar que a criação das Escolas Estaduais de Educação Profissional - EEEPs, é resultado do uso do território, regulado por uma hegemonia soberana, associada a uma hegemonia corporativa possuidora de uma força motriz (que agrega informação, capital e técnica), que induz a transformação dos territórios para atender suas prerrogativas. A educação, assim, é conduzida por esse processo, - pois é parte dele - e se adequa para atendê-lo.

Como método, contextualiza-se os processos que deram origem às primeiras iniciativas de educação no Ceará, e a constituição do ensino médio técnico nesse estado, a partir de uma periodização da formação do território cearense e da reconstituição dos principais eventos ${ }^{5}$ que contribuíram para a implantação das escolas técnicas de nível médio.

Inicialmente, necessário se faz esclarecer que a educação básica, como parte constituinte do sistema de educação brasileiro, se subdivide em: Ensino Infantil (creche ou entidades equivalentes e pré-escolas - 0 a 6 anos), Ensino Fundamental (1ํao $9^{\circ}$ ano -6 a 14 anos) e Ensino Médio (1 ${ }^{\underline{a}}$ a $3^{\text {a }}$ série -15 a 17 anos). $O$ ensino médio tem as seguintes modalidades: Ensino regular, Educação de Jovens e Adultos, Educação à Distância e Educação Profissional. (BRASIL, 2000).

A Educação Profissional está subdividida em três níveis: básico, técnico e tecnológico. Os cursos básicos independem da escolaridade prévia; os técnicos são oferecidos simultaneamente ao Ensino Médio, ou após a sua conclusão, e têm organização curricular própria; e os tecnológicos são cursos de nível superior. (Instituto nacional de Estudos e Pesquisas Educacionais Anísio Teixeira - INEP, 1999).

\footnotetext{
${ }^{5}$ Partindo da compreensão que "um evento é um feixe de vetores, conduzido por um processo, levando uma nova função ao meio preexistente. Mas o evento só é identificável quando ele é percebido, isto é, quando se perfaz e se completa. E o evento somente se completa quando integrado ao meio." (SANTOS, 2002, p. 95).
} 
Para esta pesquisa, escolheu-se a Educação Profissional Técnica de Nível Médio Integrada ao Ensino Médio, - nomeada aqui pela sigla EPMI - como tema para analisar o uso do território cearense pela atividade educacional, levando em conta a sua constituição e as características que apresenta na atualidade; ou seja, será considerado "o presente período histórico como algo que pode ser definido como um sistema temporal coerente" (SANTOS, 2008, p. 10).

Assim, buscou-se compreender a opção contemporânea pelo ensino médio técnico profissional no Estado ${ }^{6}$, embora sabendo que essa modalidade esteve presente na história da educação cearense, desde o início do século XX. Há novos elementos a serem considerados, até por que a sociedade realiza-se a cada instante e impõe ao espaço geográfico novas ações e novos objetos indissociavelmente ligados. Nas palavras de Santos (2008, p. 23), "em cada época os elementos ou variáveis são portadores (ou são conduzidos) por uma tecnologia específica e uma certa combinação de componentes do capital”.

A Educação Técnica Profissional de Nível Médio Integrada ao Ensino Médio - EMPI é, portanto, resultado do processo dinâmico da totalidade mundo que se impõe no território. Os objetos escolhidos e colocados no território são carregados de intencionalidade, onde os agentes que atuam com mais força podem selecionar o que vai ser difundido, mas o território é usado por todos, e nem sempre tudo segue a lógica idealizada por um processo racionalizador; o que resulta num conflito entre o ato de produzir e o de viver (SANTOS, 2008).

Há um conflito que se agrava entre localidade, espaço vivido por todos e um espaço global, habitado por um processo de conteúdo ideológico de origem distante, e que chega a cada local com os objetos e normas estabelecidas para servi-los (SANTOS, 2008, p. 142).

Ao mesmo tempo em que os agentes hegemônicos impõem ao território uma racionalidade perversa, o lugar resiste, ainda que de modo limitado, pois na democracia de mercado, o território é o suporte de redes que transportam regras e

\footnotetext{
${ }^{6}$ Lavínia Maria de M. Ferreira em seu artigo a Evolução e perfil da oferta de educação profissional: Brasil, grandes regiões e unidades da federação (2007 E 2012). Dispõe informações disponíveis pelo INEP que apontam uma significativa expansão das matrículas na educação profissional do país a partir de 2007, aproximadamente 626,8 mil matrículas, ou seja, um aumento de $79,3 \%$ em cinco anos. Por dependência administrativa, essa ampliação foi maior em termos relativos, na seguinte ordem: primeiramente nas redes estaduais (103,2\%); em seguida, na rede federal, com um aumento de $(97,0 \%)$; em terceiro lugar vem a oferta privada, que cresceu $63,0 \%$; por fim, situa-se a rede municipal, cuja variação foi de 23,6\% (Ferreira, 2014, 115).
} 
normas utilitárias, parciais, parcializadas, egoísticas, as verticalidades; enquanto as horizontalidades, hoje enfraquecidas, são obrigadas a levar em conta a totalidade dos agentes, especialmente nas localidades (SANTOS, 2008).

"Um dado a levar em conta é que a evolução técnica e a do capital não se fazem paralelamente para todas as variáveis" (SANTOS, 2008), cada local aglutina modos de produção particulares e concretos, pois combinam técnicas diferentes, individualmente dotados de um tempo específico, o que acarreta as diferenças entre as localidades.

Esse é um dado importante para compreender a educação técnica no Ceará, uma vez que o território incorpora novos objetos técnicos, mais as demandas crescem para a ampliação de formações profissionais específicas, o que acarreta maiores investimentos na educação técnica profissional de nível médio.

Nesse sentido, cabe referir que a técnica é alguma coisa característica do homem (ORTEGA Y GASSET, 1963) nascendo com ele graças ao seu espírito e capacidade inventiva (ORTEGA Y GASSET, 1963) ou porque não dizer, específica dele, visto que esta é uma forma que o mesmo utilizou-se e utiliza-se para constituir seu meio geográfico, tendo em vista a satisfação de suas necessidades.

É essa a dinâmica que pode ser observada no estado do Ceará, e que possibilitou a realização dessa pesquisa. De acordo com dados coletados em documentos e sites da Secretaria de Educação do Ceará (SEDUC) e do Governo do estado, houve um aumento considerável no número de Escolas Estaduais de Educação Profissional (EEEPs), sendo que só nos últimos nove anos foram construídas 116 escolas que estão localizadas em 87 dos 184 municípios (Mapa 1). Além do mais, há perspectivas para cada vez mais expandir essa modalidade de ensino no estado. 
Mapa 1: ESTADO DO CEARÁ: Escolas Estaduais de Educação Profissional por Município. 2017.

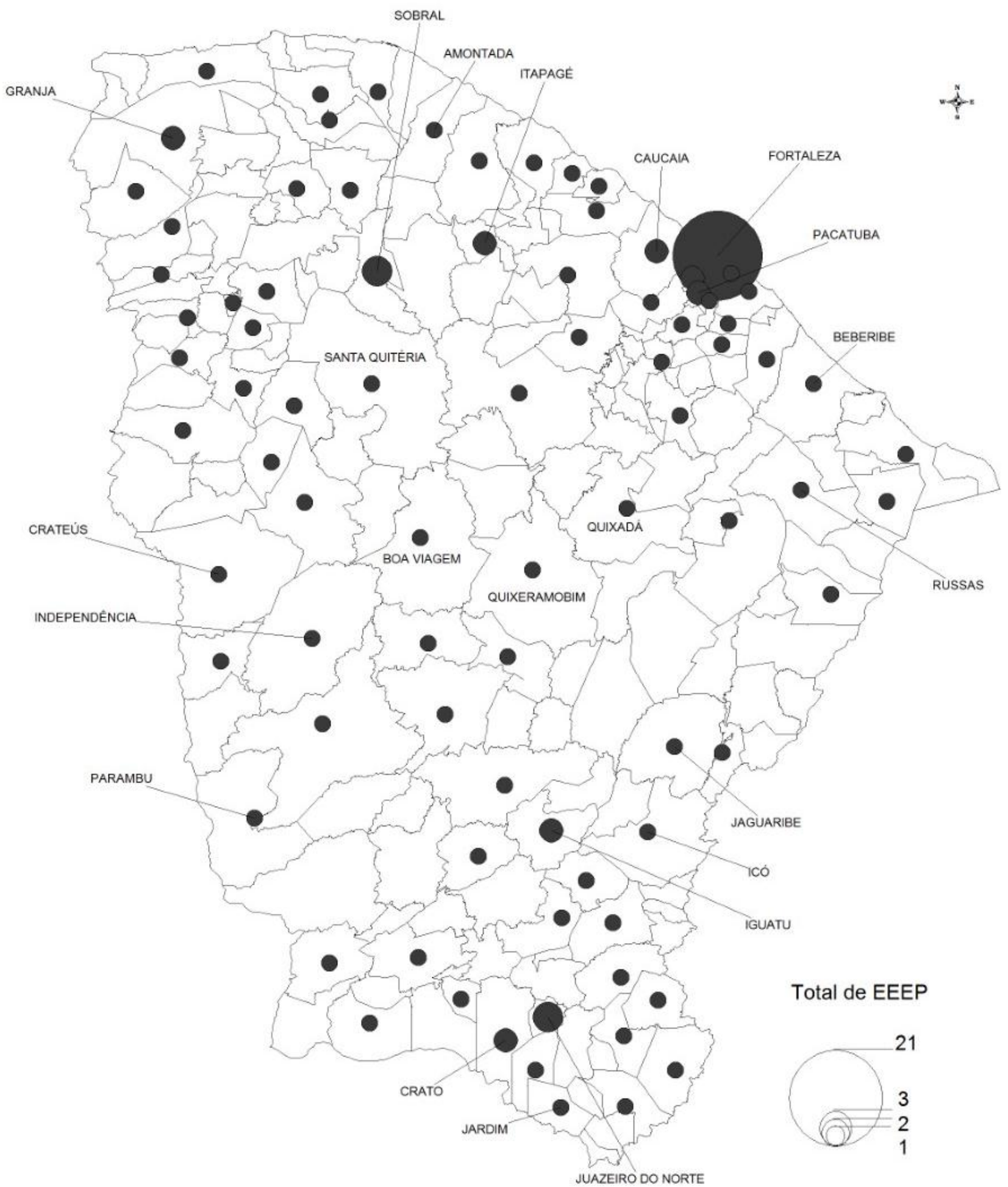

Fonte: Secretaria de Educação do Governo do Estado do Ceará. Coordenadoria de Educação Profissional - 2017.

Elaboração Cartográfica: Markelly Fonseca de Araujo. Software Maplnfo Professional.

Nota: O Estado do Ceará contabilizou 116 Escolas Estaduais de Educação Profissional em 2017. 
Buscou-se compreender quais parâmetros estão sendo utilizados para a ampliação dessa modalidade de ensino, uma vez que se torna evidente uma prática que considera determinados saberes técnicos (QUADRO 1).

\begin{tabular}{|c|c|}
\hline Eixo Tecnológico & Cursos Técnicos \\
\hline Ambiente e Saúde & $\begin{array}{l}\text { Enfermagem, Estética, Massoterapia, Meio Ambiente, } \\
\text { Saúde Bucal, Nutrição e Dietética. }\end{array}$ \\
\hline Controle e Processos Industriais & $\begin{array}{l}\text { Eletromecânica, Eletrotécnica, Manutenção Automotiva, } \\
\text { Automação Industrial, Mecânica, Química. }\end{array}$ \\
\hline $\begin{array}{l}\text { Desenvolvimento Educacional } \\
\text { e Social }\end{array}$ & $\begin{array}{l}\text { Instrução de Libras, Tradução e Interpretação de Libras, } \\
\text { Secretaria Escolar. }\end{array}$ \\
\hline Gestão e Negócios & $\begin{array}{l}\text { Administração, Comércio, Contabilidade, Finanças, } \\
\text { Logística, Secretariado, Transações Imobiliárias. }\end{array}$ \\
\hline Informação e Comunicação & Informática, Rede de Computadores. \\
\hline Infraestrutura & $\begin{array}{l}\text { Agrimensura, Móveis, Desenho de Construção Civil, } \\
\text { Edificações, Portos. }\end{array}$ \\
\hline Produção Alimentícia & Agroindústria \\
\hline Produção Cultural e Design & $\begin{array}{l}\text { Design de Interiores, Modelagem do Vestuário, Paisagismo, } \\
\text { Produção de Áudio e Vídeo, Produção de Moda, Regência. }\end{array}$ \\
\hline Produção Industrial & Fabricação Mecânica, Têxtil, Petróleo e Gás, Vestuário. \\
\hline Recursos Naturais & $\begin{array}{l}\text { Agricultura (Floricultura), Agronegócio, Agropecuária, } \\
\text { Aquicultura, Fruticultura, Mineração. }\end{array}$ \\
\hline Segurança & Segurança do Trabalho \\
\hline Turismo, Hospitalidade e Lazer & Guia de Turismo, Hospedagem, Eventos. \\
\hline
\end{tabular}

Fonte: Secretaria da Educação do Ceará, Coordenadoria de Educação Profissional, 2015.

Além disso, procura-se também entender os motivos que levam a sociedade de um Estado com uma alta taxa de analfabetismo ${ }^{7}$ e um ensino médio de baixa

\footnotetext{
${ }^{7}$ Segundo dados do Instituto Brasileiro de Geografia e Estatística (IBGE, 2017), no Brasil, em 2016, a taxa de analfabetismo das pessoas de 15 anos ou mais de idade foi estimada em 7,2\% (11,8 milhões de analfabetos) e apresentou relação direta com a idade, aumentando à medida que a idade avançava até atingir 20,4\% entre as pessoas de 60 anos ou mais. A Região Nordeste apresentou a maior taxa de analfabetismo $(14,8 \%)$, em torno de quatro vezes maior do que as taxas estimadas
} 
qualidade a se encaminhar para uma educação profissionalizante, a saber que o analfabetismo ainda é um problema a ser superado.

Karel Kosik (1976), no seu livro “A DIALÉTICA DO CONCRETO”, discute sobre essência e aparência, em suas palavras, "as coisas não se mostram ao homem diretamente tal qual são", muitas vezes falta ao homem à faculdade de ver as coisas diretamente na sua essência, por isso, a humanidade faz um desvio para conhecer as coisas e sua estrutura. "Justamente porque tal détour é o único caminho acessível ao homem para chegar à verdade, periodicamente a humanidade tenta poupar-se o trabalho desse desvio e procura observar diretamente a essência das coisas" (KAREL KOSIK, 1976, p. 21).

Segundo Kosik (1976), para conhecer as coisas em si, o ser humano deve inicialmente transformá-las em coisas para si; para conhecer as coisas como são independentemente de si, deve, antes de tudo, submetê-las à própria práxis; tem primeiramente que entrar em contato com elas para, assim, poder constatar como elas são quando não estão em contato consigo.

"O conhecimento não é contemplação (...) o homem só conhece a realidade na medida em que ele cria a realidade humana e se comporta antes de tudo como um ser prático" (KAREL KOSIK, 1976, p. 22). Compreendemos que a "pseudoalienação" dos agentes públicos em relação à perversidade do mercado e a alienação da população cearense em relação à educação técnica profissionalizante, sintetizam a ideia de que o homem tem uma dificuldade de conhecer as coisas em suas estruturas, o que reflete um distanciamento de conhecê-las em essência.

Tem-se uma espécie de "coerção consentida"8 que simboliza a alienação dos agentes pela "pseudoalienação" da política, a qual atinge seus objetivos por meio dos discursos que enfatizam ser esse tipo de educação benéfica e essencial para a formação das pessoas e para o desenvolvimento do estado.

Assim, a simultaneidade entre a ilusão forjada e a "pseudoconcreticidade" do fenômeno - investimento na educação técnica de nível médio para atender as demandas verticalizadas -, induz a alienação por meio de consenso espontâneo.

para as Regiões Sudeste (3,8\%) e Sul (3,6\%). Na Região Norte essa taxa foi $8,5 \%$ e no CentroOeste, $5,7 \%$. No Ceará a taxa de analfabetismo é de $15,2 \%$, sendo a quinta maior do país (IBGE, 2017).

${ }^{8}$ Ver: HARVEY, David. O novo imperialismo. 2. ed. São Paulo: Loyola, 2005. 
No intuito do détour, questionou-se sobre o encaminhamento da educação técnica de nível médio integrada, na tentativa de refletir sobre qual é o modelo de ensino técnico o Ceará precisa ou quer, para viabilizar seu projeto de futuro. Assim questiona-se: o Ceará já resolveu seus problemas básicos educacionais? Qual o projeto de futuro está o Ceará expresso nos Planos de Governos e nas Politicas Educacionais? Como o uso do território responde a tudo isso?

Vale ressaltar que as circunstâncias que conduziram essa modalidade de ensino no estado do Ceará, são múltiplas, e os elementos que o regulam têm sido objeto de leis, normas, políticas e programas nacionais, alguns dos quais em convênio com órgãos internacionais. Por isso, considerou-se o movimento e as demandas da sociedade a partir do próprio ensino médio técnico profissional e o território, esse como mediação entre o mundo e o lugar.

O lugar, compreendido "como funcionalização do mundo" e ao mesmo tempo reflexo dele, sendo que "é por ele (lugar) que o mundo é percebido". (SANTOS, 2005, p. 158). Pois ele, o lugar não reúne características autônomas, nem desvinculadas da totalidade do sistema de objetos e ações que compõem o espaço geográfico.

Ao contrário, no lugar verticalidades e horizontalidades se entrelaçam e se afirmam "mediante um controle local da parcela técnica da produção e um controle remoto da parcela política da produção" (SANTOS, 2008, p. 141).

Ambos intervêm na configuração do território, e é dessa relação lugar/mundo, que surgem as demandas provenientes dos sistemas técnicos globalizados, que reestruturam as formas espaciais acrescentando-Ihes novos objetos técnicos, criando novas funções e concomitantemente as ações para efetiválas.

Por sua vez, essas demandas globalizadas, em sua maioria interferem na criação de demandas internas para a sociedade cearense, pois, as necessidades elementares para se viver e usar o território a partir de uma produção a nível local, como os serviços de interesse coletivo (Alimentação, Educação, Moradia, Segurança) são suprimidas e/ou se adequam para atender aos grandes investimentos de interesse econômicos que se dão em escala global.

De modo que o Estado passa a ofertar cursos técnicos para atender determinados setores comandados por grandes firmas, bancos e indústrias em 
detrimento de outros setores que carecem de atenção, como os serviços de saúde, educação, de atenção social, dentre outros.

Nesse processo, o território refuncionaliza-se, ganha novas formasconteúdo 9 e impõe novos comportamentos e por meio dessa refuncionalização inovadora do ponto de vista técnico e tecnológico -, criam-se necessidades de novas formações no âmbito educacional.

Pois, o processo de implantação de novos objetos e novas técnicas cria demandas por conhecimentos, vindo essas a se associarem a outras demandas, que requer novos conhecimentos e assim sucessivamente. Há uma influência recíproca entre educação e uso do território, mediado pelo lugar.

"Lugares e sistemas de lugares, pelas suas características econômicas, demográficas e sociais constituem fatores relevantes da explicação das diferenciações geográficas da atividade educacional” (SANTOS, 2000, p. 25). Pois os mesmos, "se definem pela sua densidade técnica, pela sua densidade comunicacional, cuja fusão os caracteriza e distingue" (SANTOS, 2005, p. 160). "Os lugares, assim, são aparatos de base das funcionalizações que as relações sociais vão sempre exigindo do uso do território" (SOUZA, 2008, p. 45).

A geografia, por ser uma ciência que busca apreender a dinâmica da totalidade do mundo pelo uso, oferece-nos a possibilidade do debate entre território usado e educação técnica profissional.

Portanto, o estudo tem o intuito de contribuir para a análise do uso território cearense pela EPMI, em sua realidade; visto que, baseando-se no estado da arte, as pesquisas geográficas voltadas para esse assunto ainda são poucas, considerando também que a proposta do ensino médio técnico integrado é recente, tendo sido regulamentado em 2008, Lei no 11.741 (BRASIL, 2008).

Como subsídio, os conhecimentos teóricos sobre essa modalidade de educação foi fundamental, pois permitiram analisar quais são as outras formas de manifestações da educação podem ser possíveis e relevantes, para a construção de um modelo de educação, que considere a formação humana um elemento primordial para uma sociedade mais justa e equânime.

\footnotetext{
${ }^{9}$ De acordo com Santos (2012, p 12-13) "as formas geográficas contêm frações do social, não são apenas formas, mas formas-conteúdo. Por isso estão sempre mudando de significações, na medida em que o movimento social Ihes atribui, a cada momento frações diferentes do todo social".
} 
No que concerne à pesquisa bibliográfica, ressalta-se que foram realizadas consultas ao acervo disponível em algumas instituições universitárias, como a Universidade de São Paulo - USP, Universidade Federal do Ceará - UFC, Universidade Estadual do Ceará - UECE e Universidade Federal do Rio de Janeiro - UFRJ. A escolha dessas instituições se deu por alguns motivos, tais como: ser uma delas a instituição que é abrigo do curso que propiciou a pesquisa, possuir um acervo que ajudou no seu desenvolvimento, ter trabalhos e pesquisas na área pesquisada, possuir livros, periódicos, artigos, teses e dissertações e monografias que abordavam parte do assunto, dentre outros.

Ressaltam-se também as pesquisas e levantamentos de dados e informações junto à Secretaria da Educação do Governo do Estado do Ceará, a Biblioteca da Secretaria de Educação do Estado do Ceará, Biblioteca Municipal de Sobral, em sites como: o portal MEC do Ministério da Educação - MEC, Secretaria de Educação do Estado do Ceará - SEDUC, bem como, os principais órgãos responsáveis pela geração de estudos, pesquisas e informações socioeconômicas e geográficas do Estado, como o Instituto Brasileiro de Geografia e Estatística - IBGE e o Instituto de Pesquisa e Estratégia Econômica do Ceará - IPECE.

As pesquisas realizadas junto a esses órgãos foram fundamentais, pois forneceram dados e informações sobre as características dos municípios onde estão localizadas as Escolas Profissionais de Ensino Médio como, por exemplo, economia, infraestrutura, número de habitantes, número total de escolas, taxa de escolarização e analfabetismo, incidência da pobreza, dentre outros dados e características importantes que possam ser pertinentes para a tese.

A pesquisa em bases de dados junto ao Ministério da Educação (MEC), o Instituto Brasileiro de Geografia e Estatística (IBGE) e as instituições públicas cearenses do Ensino Básico, principalmente as Escolas de Educacional Profissional, também teve grande importância, visto que propiciou o levantamento de informações a partir de anuários estatísticos e compêndios de dados, bem como informações sobre o funcionamento das escolas. Todas essas informações auxiliaram para contextualizar o processo histórico da constituição do ensino médio técnico nesse Estado.

Também foi realizado visitas e consultas a algumas instituições como o Arquivo Público do Estado do Ceará e a Biblioteca do Conselho de Educação do 
Ceará, no intuito de buscar documentos que pudessem contribuir para análises sobre o ensino publico cearense.

Foram feitas várias entrevistas, dentre elas destaca-se: a concedida pelo exgovernador do Ceará Cid Gomes (2006/2014), por tratar-se do responsável pela efetivação da proposta para a implantação das EEEPs, a qual ocorreu durante o seu governo, bem como a expansão delas por quase todo o Ceará.

A entrevista buscou principalmente respostas para compreender a opção pelo ensino médio técnico. Outra entrevista foi concedida pela coordenadora da Educação Técnica do estado no intuito de obter informações a respeito da condução dessa modalidade de ensino, saber se há novas propostas, se se prevê mudanças, se estão sendo feitos estudos sobre a repercussão desse modelo de ensino, e avaliar as perspectivas futuras para essa modalidade de ensino a curto e longo prazo.

Entrevistou-se no Complexo Portuário do Pecém o coordenador de Desenvolvimento Comercial e Planejamento da Companhia de Integracão Portuária do Ceará, o senhor Raul Neris, técnicos nos Perímetros Irrigados de Tabuleiro de Russas e Jaguaribe-Apodi. O objetivo das entrevistas realizadas, foi buscar compreender algumas demandas territoriais que vem surgindo no Ceará decorrentes do meio técnico-científico-informacional.

Foram também realizadas entrevistas com diretores e diretoras, coordenadoras e coordenadores de algumas EEEPs. O intuito dessas foi, sobretudo, obter informações sobre as escolas, como seu funcionamento, os cursos, sua organização, etc.

Foi feito visita de campo na capital e em várias cidades do estado para coleta de dados referentes à pesquisa, privilegiando as que contavam com Escolas Técnicas Profissionais de Nível Médio Integrado, como: Icó, Quixadá, Juazeiro, Crato, Barbalha, Sobral, Fortaleza, Caucaia, Ubajara, Viçosa, Tianguá, Reriutaba, Itapipoca, Cariré, São Benedito, Aracati, Jijoca, Trairi, São Gonçalo do Amarante, Tauá, Guaramiranga, Redenção, Ipueiras, Massapê, Iguatu, Russas, Limoeiro do Norte, Santana do Cariri, Assaré.

Por serem cidades que apresentam algumas características distintas, foi preciso percorrê-las para compreendê-las do ponto de vista das demandas de cada uma delas, e, assim, analisar até que ponto os cursos ofertados poderiam estar suprindo ou não essas demandas. Ressalta-se que foram feitos registros 
fotográficos e anotações sobre as dinâmicas das localidades visitadas para posterior análise.

Enfatiza-se que o reconhecimento do funcionamento destas escolas e a leitura das dinâmicas das cidades, foram de fundamental importância para o aprofundamento das questões que são abordadas na tese, e foram significativas do ponto de vista do método escolhido para a análise da educação técnica do Ceará e quiçá no Brasil.

A tese está dividida em três partes, a primeira, intitulada "A constituição do território cearense e a educação", apresenta uma análise dos processos que induziram fortes mudanças no espaço geográfico brasileiro fazendo-o constituir-se a partir de modos de produção, que antes eram inexistentes no território usado, os quais impulsionaram novas relações socioespaciais, que incidiram no uso do território do Ceará e no seu processo de organização e condução da educação.

A periodização da formação socioterritorial do Ceará e os eventos principais foram analisados para compreender os processos que originaram às primeiras iniciativas de educação e o ensino técnico. De modo que, a partir dessa análise se pudesse refletir sobre como os usos do território contribuíram para a implantação das Escolas Técnicas Profissionais de Nível Médio Integrada ao Ensino Médio.

Essa discussão se desdobra em dois capítulos. No primeiro, discute-se a constituição histórica do território usado cearense e suas primeiras iniciativas de educação, decorrentes do processo de ocupação europeia no Brasil e no Ceará, seguida pelo binômio gado-algodão, que impulsionou novos usos do território e novas demandas, tendo como resultado novas maneiras de conduzir a educação para atendê-los.

O segundo capítulo fomenta a discussão sobre a formação de um mercado interno, a partir dos usos do território cearense pela cultura do algodão. Nesse contexto, mostra-se como esse processo subsidiou a instalação de infraestruturas e novas relações socioterritoriais, e como induziu o aparecimento de instituições de ensino que pudessem atendê-las, como as escolas profissionais.

Na segunda parte: "Globalização, meio técnico-científico-informacional e as novas demandas educacionais no Ceará", debate-se a constituição das demandas a partir dos usos do território cearense. Para tanto, se questiona: Por que o meio técnico se instala? Que fatores são determinantes para a geração das novas demandas? Para subsidiar a discussão, são utilizados os conceitos de verticalidades 
e horizontalidades, no intuito de compreender o surgimento de novos objetos e novas ações no espaço geográfico, e como isso colabora para a opção pela educação Técnica.

O terceiro capítulo discute a constituição do meio-técnico-científicoinformacional a partir dos usos do território cearense e seus reflexos nas politicas educacionais, que têm sua condução e elaboração influenciada em grande parte por decisões de organismos internacionais na elaboração dessas políticas. Nesse contexto, faz-se uma análise do surgimento das demandas no território, que buscam sobremaneira atender setores ligados à economia mundial.

O capítulo quatro apresenta uma discussão sobre o uso do território a partir dos processos de desenvolvimento do capitalismo, no período da chamada globalização econômica, onde a divisão do trabalho especializado requer a formação dos trabalhadores, tendo como resultado a refuncionalização da educação para atender as novas demandas oriundas da economia mundial

$\mathrm{Na}$ última parte: "Ações e normatizações para a Educação Técnica Profissional de Nível Médio Integrada e o uso do território cearense: as contradições entre 0 ato de produzir e viver e outras possibilidades", faz-se uma análise das políticas voltadas para a Educação Técnica Profissional de Nível Médio Integrada ao Ensino Médio, a partir das leis e normatização, no intuito de buscar compreender o projeto educacional dessa modalidade e a sua organização política territorial. Para subsidiar a análise se questionou: As normas e leis estão de acordo com a realidade das localidades ou essas se sobressaem para atender a hegemonia do mercado?

Assim como as outras, esta parte também se divide em dois capítulos, o quinto, discute as leis e normatizações no contexto do uso do território, as quais fundamentam a opção por essa modalidade de ensino e a implantação dessas escolas.

E o sexto capítulo, onde se reflete sobre as implicações que a modalidade ensino técnico profissional pode conferir ao território. Portanto, analisa-se o uso do território pela EPMI, no intuito de compreender que conflitos podem ser gerados entre $o$ ato de produzir para um mercado e de viver. Nesse capítulo, também se propõe alternativas para ações advindas das políticas pensadas para uma demanda alheia a realidade local, mostrando que há outras possibilidades de se pensar a 
educação, para além das políticas voltadas para o mercado, onde outras formas de desenvolvimento local e coletivo podem ser possíveis.

Ressalta-se que o propósito do trabalho foi refletir sobre o uso território pela EPMI, utilizando-se de um método geográfico verificável. Essa reflexão se desenvolve ao longo da escrita da tese, e busca dar uma contribuição para estudiosos e pesquisadores que se dedicam a essa temática. Espera-se que as análises sobre seus impactos no território torne-se um importante objeto de estudo, pela relevância que assume no contexto socioespacial brasileiro e nas decisões futuras sobre a educação cearense. 


\section{PARTE I}

\section{A CONSTITUIÇÃO DO TERRITÓRIO CEARENSE E A EDUCAÇÃO}


Foto 1: Os jesuítas e as primeiras iniciativas de educação no Brasil e no Ceará

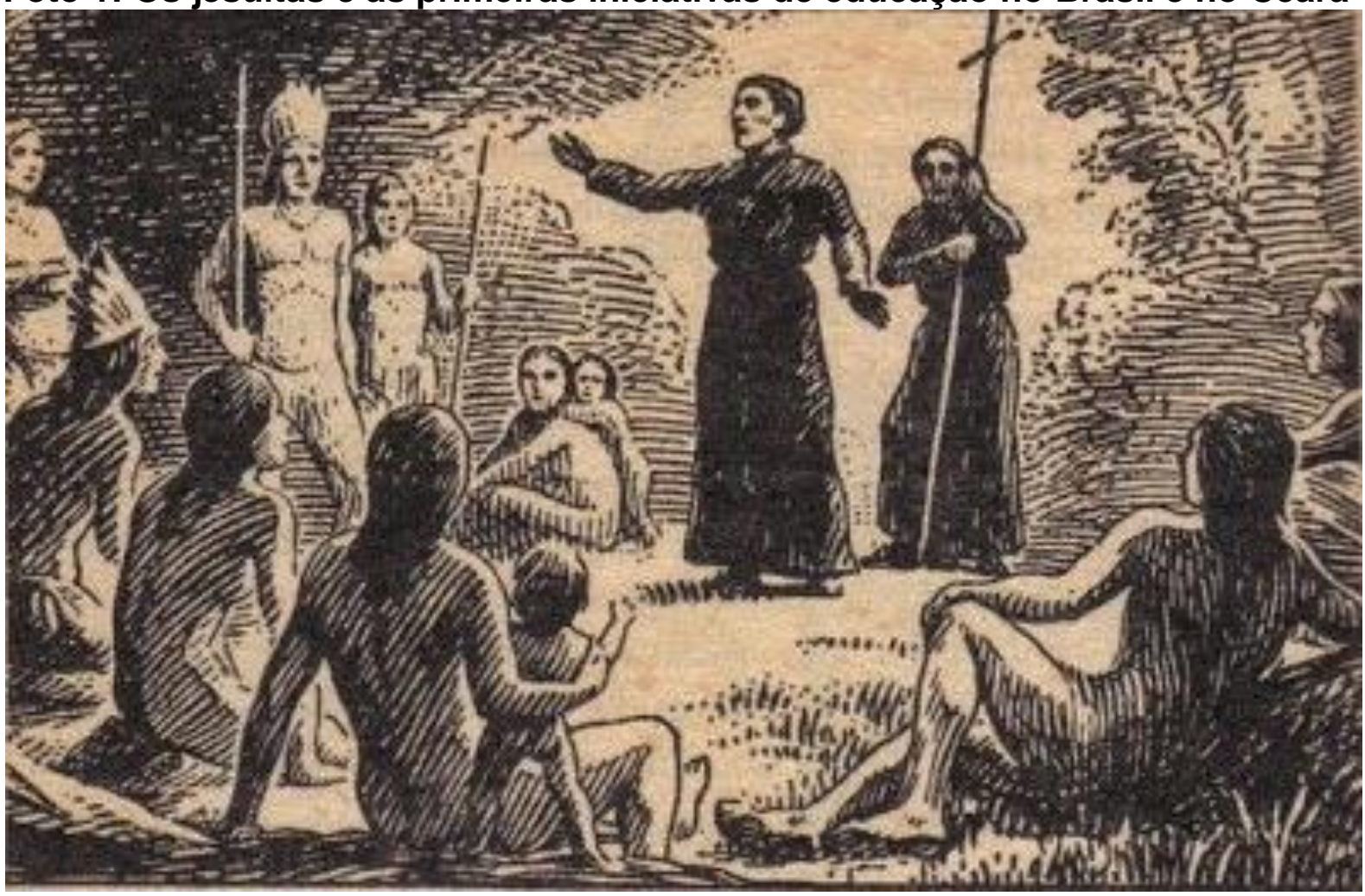

Fonte: $\quad$ http://www.ibamendes.com/2011/03/companhia-de-jesus-no-brasil-e-obrada.html

Essa primeira parte da tese apresenta uma análise dos aspectos que impulsionaram mudanças relevantes no território brasileiro e proporcionaram novos modos de produção e novas relações socioespaciais, as quais incidiram no uso do território do Ceará e no seu processo de organização e condução da educação.

A partir de uma periodização da constituição do Ceará e da reconstituição dos principais eventos, contextualizam-se os processos que deram origem às primeiras iniciativas de educação nesse estado e ao ensino técnico. Em seguida, analisam-se as modificações que se processaram a partir da pecuária e da cultura do algodão, as quais impulsionaram novas demandas. Essas, por sua vez, constituíram outros modos de usos, e com o avanço das técnicas, contribuíram para o surgimento da educação profissional, que vem se expandindo cada vez mais e se modificando a partir do território usado. 
CAPÍTULO 1

\begin{abstract}
A PRESENÇA EUROPEIA NO BRASIL E NO CEARÁ E AS PRIMEIRAS INICIATIVAS DE EDUCAÇÃO NO TERRITÓRIO: DA PECUÁRIA À MODERNIDADE
\end{abstract}

Neste capítulo, discute-se a constituição do Ceará e suas primeiras iniciativas de educação, tomando como pressuposto o processo de ocupação europeia no Brasil e no território usado cearense. A fim de dar subsídios para a discussão, faz-se um resgate dos modos de vida dos primeiros habitantes e a sua relação com o meio geográfico, dando continuidade, discute-se as transformações que decorreram desse processo e resultaram no binômio gado-algodão, os quais foram impulsionadores de novos usos do território e conduziram a educação a atender às novas demandas que foram surgindo a partir desse processo. 


\section{Capítulo 1. A presença Europeia no Brasil e no Ceará e as primeiras iniciativas de educação no território: da pecuária a modernidade}

Todo povo tem na sua evolução, vista à distância, um certo "sentido". Este se percebe não nos pormenores de sua história, mas no conjunto dos fatos e acontecimentos essenciais que a constituem num largo período de tempo (PRADO JUNIOR, 1989, p.1).

A história da constituição do território usado cearense agrega aspectos peculiares e gerais da história do Brasil, pois é a síntese das relações verticais e horizontais que se deram no espaço geográfico e tiveram repercussões em todo o território nacional com reflexos diretos na educação. A compreensão desta, em seu processo e na atual realidade, se dá por intermédio da periodização, pois "os períodos, são pedaços de tempo definidos por características que interagem e asseguram o movimento do todo" (SANTOS, 2008, p. 24).

Tem-se com isso, uma parte importante do método para o desenvolvimento do assunto aqui abordado. Trata-se inicialmente de uma análise reflexiva dos acontecimentos mais relevantes que condicionaram o que iria se constituir o Ceará e a educação.

É fundamental mencionar que "o espaço acumula defasagens e superposições de divisões do trabalho - sociais e territoriais". De um ponto de vista genérico, "as variáveis do espaço são assincrônicas, mas em cada lugar elas funcionam sincronicamente e tendem a ser assim também quanto ao todo" (SANTOS, 2008, p. 24).

Esta resulta de um sistema de eventos, que envolvem a interação entre o ordenamento que havia, e os diversos fatores que desmancharam a harmonia do conjunto e determinaram a sua ruptura. Esses eventos incidiram a nível nacional, mas repercutiram diferentemente nas 'regiões', obtendo-se como resultado as descontinuidades e desequilíbrios regionais, principalmente em se tratando da Educação. 
Por isso, a escolha da periodização aqui proposta a partir das verticalidades e horizontalidades, se dá em conformidade, não somente com os eventos que se processaram em escala nacional - que tem suas bases no chamado meio natural -, mas, sobretudo, com a compreensão das articulações entre esses e as demandas do exterior, que induziram a constituição do território cearense e a organização da educação.

O que está aqui posto é um esforço de reflexão sobre o que seriam as bases da geohistoriografia do Ceará, para entender os processos que impulsionaram o surgimento da Educação Técnica de Nível Médio, compreendendo como esta surge e qual a sua finalidade.

Os períodos a que se refere essa tese são os que induziram as relações econômicas e sociais, e influenciaram a organização do trabalho e das demandas territoriais que subsidiaram o tipo de educação e a sua destinação.

\section{Pressupostos da colonização: 0 domínio dos novos territórios}

Sobre a presença europeia no território brasileiro, algumas considerações são necessárias, visto que esse evento tem suas raízes num conjunto de antecedentes que iriam desencadear na busca da atividade colonizadora e que acabaria por suscitar a ocupação e povoamento do território que constituiria o Brasil.

O processo que acabaria por integrar todo o espaço global em uma nova ordem, que é a do mundo moderno, em que a Europa, ou antes, a sua civilização, se estenderia dominadora por toda parte, e se concretiza com a expansão marítima (PRADO JUNIOR, 1989, p. 9).

Esta por sua vez "se origina, sobretudo, do empenho de simples empresas comerciais levadas a efeito pelos navegadores daqueles países. Deriva do desenvolvimento do comércio continental europeu - que até o século XIV é quase unicamente terrestre, e limitado, por via marítima, a uma mesquinha navegação costeira e de cabotagem" (PRADO JUNIOR, 1989, p. 10) - e, também, do avanço das técnicas de navegação e dos meios de transporte por mar, que proporcionou um novo sistema de relações internas comerciais e culturais. 
Entretanto, vale ressaltar que o seu caráter e motivações estão vinculados ao desenvolvimento técnico e a divisão do trabalho que é base e resultado dos usos de um dado território, que cria e recria sistemas diversificados de produção.

Neste sentido, alguns países da Europa desenvolveram relações capitalistas impulsionadas pelo aumento da produtividade, como o monopólio do comércio e a circulação financeira, proporcionando a colonização no além-mar ${ }^{10}$.

Além disso, a passagem de um modo de produção a outro, mesmo carregando seus resquícios e influências, faz surgir novos usos, com o surgimento de novas atividades e relações econômicas; enquanto empreendimentos resultantes de acumulação de capital e da busca por novas rotas comerciais e mercadorias para suprir um mercado que crescia e carecia de bens e produtos ${ }^{11}$.

Era uma projeção dos avanços civilizatórios alcançados pelos europeus, proporcionados pelos usos das técnicas e dos modos de produção. Era a busca de ouro, terras, cereal, e outros tantos produtos. São as decisões políticas e um sistema financeiro que permite uma acumulação primitiva tornando a dinâmica do espaço geográfico mais diversificada com as trocas e fluxos.

O papel de pioneiro nesta nova etapa, coube aos portugueses; os melhores situados, geograficamente, no extremo desta península que avança pelo mar. Atrás dos portugueses lançam-se os espanhóis, os franceses, os ingleses, os holandeses, e até os dinamarqueses e os suecos (PRADO JÚNIOR, 1956).

A grande navegação oceânica estava aberta, e todos procuravam tirar partido dela. Só ficaram atrás, aqueles que dominavam no antigo sistema comercial terrestre ou mediterrâneo, e cujas rotas iam passando para o segundo plano: mal situados, geograficamente, com relação às novas rotas, e presos a um passado que ainda pesava sobre eles; os mesmos serão os retardatários da nova ordem. A Alemanha e a Itália ficaram num plano secundário juntamente com os países ibéricos, a Inglaterra, a França e a Holanda (PRADO JÚNIOR, 1956, p. 14).

Em suma e no essencial, todos os grandes acontecimentos desta era, que se convencionou com razão chamar dos "descobrimentos", articulam-se num conjunto que não é senão um capítulo da história do comércio europeu. Tudo que se passa são incidentes da imensa

\footnotetext{
${ }^{10}$ Ver Chaunu. A conquista e exploração dos Novos mundos (século XVI) 383-4; Wallerstein. EI moderno sistema mundial. Fernando Braudel. Civilização material: Economia e capitalismo sec. XVXVIII.

${ }^{11}$ Idem.
} 
empresa comercial a que se dedicam os países da Europa a partir do séc. XV, e que Ihes alargará o horizonte pelo Oceano afora (PRADO JúNIOR, 1956, p. 14).

A expansão pelos mares, configura-se em guerras de conquista, de saqueio e evangelização sobre os povos da África, da Ásia e, sobretudo, das Américas. Constitui-se, assim, "os fundamentos do primeiro sistema econômico mundial, interrompendo o desenvolvimento autônomo das grandes civilizações americanas" (RIBEIRO, 1995, p. 65).

Todavia a ideia de povoar e ocupar efetivamente não ocorre inicialmente a nenhum. É o comércio que os interessa, é a busca pelo lucro proporcionado por atividades mercantis que induz a colonização, daí resulta o relativo desprezo por territórios como o do Brasil, e inversamente, o prestígio do Oriente, onde não faltava objeto para atividades mercantis (PRADO JúNIOR, 1956).

A ocupação só surgiu como contingência, necessidade imposta por circunstâncias novas e imprevistas. O receio de perder as terras recém-conquistadas para outros povos conquistadores que já se faziam presentes, foi uma delas.

A ideia de ocupar não era prioridade; o que se pretendia era organizar em simples feitorias apenas como agentes comerciais, funcionários e militares para a defesa, destinados a mercadejar com os nativos e servir de articulação entre as rotas marítimas e os territórios ocupados (PRADO JÚNIOR. 1989).

"Nestas condições, "colonização" ainda era entendida como aquilo que dantes se praticava; fala-se em colonização, mas o que o termo envolve não é mais que o estabelecimento de feitorias comerciais" (PRADO JÚNIOR, 1956, p. 16).

Também, as ocupações dos novos territórios variaram com a natureza dos gêneros que deles poderiam ser aproveitados, como madeiras para produzir tintas ou para construção, peles, metais, e mais tarde, açúcar, algodão, café, dentre outros. Esse tipo de comércio perdurou e serviu como base para a agricultura através do recrutamento do trabalho dos indígenas e seguidamente dos "negros" africanos.

De acordo com Prado Júnior (1956), esse processo objetivava atender aos interesses exteriores, voltados para fora do país e sem atenção a considerações que não fossem o daquele comércio. Nesse cenário se constituiu a sociedade e a economia brasileira, "com elementos articulados numa organização puramente produtora e mercantil [...] e que se manterá dominante através dos séculos e [...] se 
gravará profunda e totalmente nas feições e na vida do país" (PRADO JÚNIOR, 1956, p. 23).

\section{O território, seus habitantes e suas relações com o meio geográfico}

No território brasileiro habitavam, em sua quase total extensão, milhares de povos de diferentes etnias que se alojavam, desalojavam e realojavam incessantemente (RIBEIRO, 1995, p. 29). Concebiam o direito de propriedade sob um aspecto coletivo e apresentavam uma organização econômica e socioespacial praticamente igual.

Variados instrumentos de trabalho elaborados e feitos lentamente, assim como os seus manuseios, além da domesticação de animais e conhecimentos de plantas que fizeram despontar a agricultura, e inscreveram um momento singular e fundamental da história humana.

Todavia, esse processo não significou a implantação de próteses nos lugares, mas a imposição à natureza de um primeiro esboço da presença técnica, pois ritmos e regras humanas buscavam sobreporse as leis naturais. Todavia a natureza comandava, direta ou indiretamente as ações humanas. A precariedade ou a pobreza das técnicas disponíveis constituía o corpo do homem como principal agente de transformação tanto na produção como no enfrentamento das distâncias, e ainda aqui a natureza triunfa e o homem se adapta. (SANTOS, 2008, p. 29).

Segundo Darcy Ribeiro (1995) na escala da evolução cultural, esses habitantes davam os primeiros passos da revolução agrícola - quando foram surpreendidos pela presença do europeu - e os faziam por um caminho próprio.

"Criaram objetos de eventual semelhança com técnicas de outros povos" (SANTOS, 2008, p. 29), as quais eram criadas espontaneamente, tendo como estímulo as necessidades de cada local e atividades a serem desenvolvidas com seus usos.

Cultivavam já diversos gêneros alimentícios, como o milho, a batata doce, o feijão, a abóbora, o algodão, pimentas, abacaxi, mamão, a erva-mate, o guaraná, dentre outras. Também faziam roçados preparando o terreno com objetos de pedra. 
Praticavam a caça e a pesca para obter outros alimentos usando tacapes, arcos e flechas (RIBEIRO, 1995). Fabricavam vinho, objetos de adorno, cerâmicas e redes de dormir (GIRÃO, 1953, p. 31-32).

Territorialmente, os locais que garantiam maior regularidade à sobrevivência permitiam aldeamentos maiores (RIBEIRO, 1995).

Em certos locais especialmente ricos, tanto na costa marítima quanto nos vales mais fecundos, esses aldeamentos excepcionais chegavam a alcançar 3 mil pessoas. Eram, todavia, conglomerados pré-urbanos (aldeias agrícolas indiferenciadas), porque todos os moradores estavam compelidos à produção de alimentos, só liberando dela, excepcionalmente, alguns líderes religiosos (pajés e caraibas) e uns poucos chefes guerreiros (tuxáuas) (RIBEIRO, 1995, p. 32).

Eram povos tribais "que falavam línguas do mesmo tronco, dialetos de uma mesma língua, cada um dos quais a crescer, se bipartia, fazendo dois povos que começavam a se diferenciar e logo se desconheciam e se hostilizavam" (RIBEIRO, 1995, p. 32).

Esses modos de se relacionarem e viverem eram comuns no território brasileiro. No Ceará, os povos indígenas apresentavam características semelhantes, apenas com algumas alterações oriundas das condições naturais preexistentes na região, aliadas à sua cultura de origem (GIRÃO, 1953, p. 28).

O direito de propriedade era considerado sob o aspecto coletivo. A extensão de terra destinada à vida da tribo pertencia a todos. "Ao lado dessa grande comunhão, existia o condomínio familial, sobre a casa, a grande oca, teto de várias famílias, que aí residiam conjuntamente, sem que nenhum tivesse a noção de tocarlhe determinada porção do imóvel" (GIRÃO, 1953, p. 29).

Nesse quesito, segundo Girão (1953), os objetos, como armas, ornatos, instrumentos de trabalho, pertenciam a quem os fabricassem ou os achassem, e os demais deveriam aceitar e respeitar a apropriação.

Todas essas atividades, que entrosavam a vida cotidiana dos agrupamentos índios, se desenvolviam no pequeno círculo das tabas, sem que se mantivessem, de tribo a tribo, relações de mercancia ou doutra natureza, e obedeciam a uma já bem articulada divisão do trabalho, de modo a caberem determinadas tarefas produtivas a determinadas pessoas, conforme o sexo ou a idade (GIRÃO, 1953, p. 32). 
O território brasileiro era, dessa maneira, usado de acordo com as ofertas da natureza, cabendo aos seus habitantes adaptar-se às suas condições para garantir sua sobrevivência. A ocupação dessas terras vinculava-se a um tempo natural ou, no dizer de Milton Santos (2008), era caracterizada pelos tempos lentos.

\section{A presença Europeia no Brasil e no Ceará}

É acordado entre um grande número de historiadores que, oficialmente, o "descobrimento" do território brasileiro se deu em Abril de 1500, pelo Almirante Pedro Alvares Cabral, depois de chegar a um porto bom e seguro - a enseada de Santa Cruz - indicando a posse da nova terra (GIRÃO, 1953). "No entanto, há divergências entre geógrafos e historiadores, no tocante ao descobrimento de fato, defendendo uns a precedência cronológica dos espanhóis e outros a dos lusos". (GIRÃO, 1953, p. 17).

Em busca de terras e riquezas e estimulados pela viagem de Cristóvão Colombo, muitos navegadores enfrentaram os mares, alguns exemplos são: a empreitada da Espanha com Alonso Hojeda, Juan de La Cosa e Américo Vespúcio que chegou ao Cabo Orange, porém sem atingir terras brasileiras. Outra, sob a responsabilidade de Vicente Yanes Pizon, proveniente do Porto de Palos, que ultrapassou a linha equatorial e chegou num ponto do continente americano, num cabo que foi nomeado por Santa Maria de la Consolación (Ponta-Grossa/Aracati), onde desembarcou para abastecer os navios de agua e lenha. E porque o local apresentava um solo muito árido e os habitantes que se esquivaram de qualquer contato, velejou Pizon para o norte terminando por alcançar o Amazonas. Finalmente retornando para Palos em setembro de 1500.

Também navegaram de Palos, duas caravelas sob o comando de Diogo Lepe, que atracou nas águas do Rio Grande do Norte, rumando em seguida ao norte, onde encontrou a Cruz deixada por Pizon e chamou o local de Rostro Hermoso (ponta do Mucuripe/Fortaleza) (GIRÃO, 1958).

Todas essas rotas e descobertas não puderam ser oficializadas devido ao tratado de Tordesilhas. Além disso, de modo geral, os historiadores portugueses não aceitam que essas expedições tenham alcançado terras brasileiras. 
No entanto, Pompeu Sobrinho, por meio de pesquisas e exames em cartografias portuguesas, italianas e espanholas, argumenta que as expedições de Pizón e Lepe antecederam a expedição de Cabral, e que foi nas praias de Ceará que o europeu viu, pisou e sentiu pela primeira vez, a terra brasileira. (GIRÃO, 1953, p. 19).

Segundo Girão (1953, p. 19), "após 1500 e até a bandeira de Pero Coelho, em 1603, o litoral cearense foi objeto de excursões náuticas, assim de navegadores oficiais, como de flibusteiros ${ }^{12}$ em busca de resgates com índios".

Entre a sua "descoberta" e "efetiva" ocupação, já havia sido lugar de trocas e tráfico de mercadorias como: facas, canivetes, machados, panos, anzóis, espelhos, pentes, contas; trocados por matérias primas, e espécies de animais e passáros. Além dos paus de cores comuns às matas cearenses, como a tatajuba e o pauvioleta $^{13}$. (GIRÃO, 1953, p.21-22).

"Esses escambos intensificaram-se no século XVII e não foi fácil coibí-los a fim de garantir só aos portugueses a exploração das novas terras" (GIRÃO, 1953, p.23).

Vale ressaltar que, apesar de todos os esforços empreendidos para encontrar novas rotas comerciais, os poucos recursos que a metrópole dispunha eram insuficientes para cuidar da colonização da Terra de Santa Cruz (GIRÃO, 1947).

Mais de um século iria decorrer sem se pensar na posse e defesa do patrimônio. Foi necessário que houvesse informes alarmantes sobre a ação crescente de piratas estrangeiros nas costas do Brasil para que finalmente a metrópole resolvesse defender o território recém-conquistado.

A fórmula encontrada foi a adoção do sistema de capitanias (Mapa 2) com doações de grandes faixas de terras a pessoas nobres, que fossem capazes de as povoar com recursos próprios, de as defender e fazê-las produzir, tanto para si como para a fazenda real (GIRÃO, 1947, p.8).

\footnotetext{
${ }^{12}$ Classe de antigos piratas das Américas.

${ }^{13}$ Espécie de árvore comum nas matas cearenses que tem o lenho de coloração roxa, era bastante disputada, pois era utilizada para a fabricação de móveis de luxo.
} 
Mapa 2: Capitanias Hereditárias

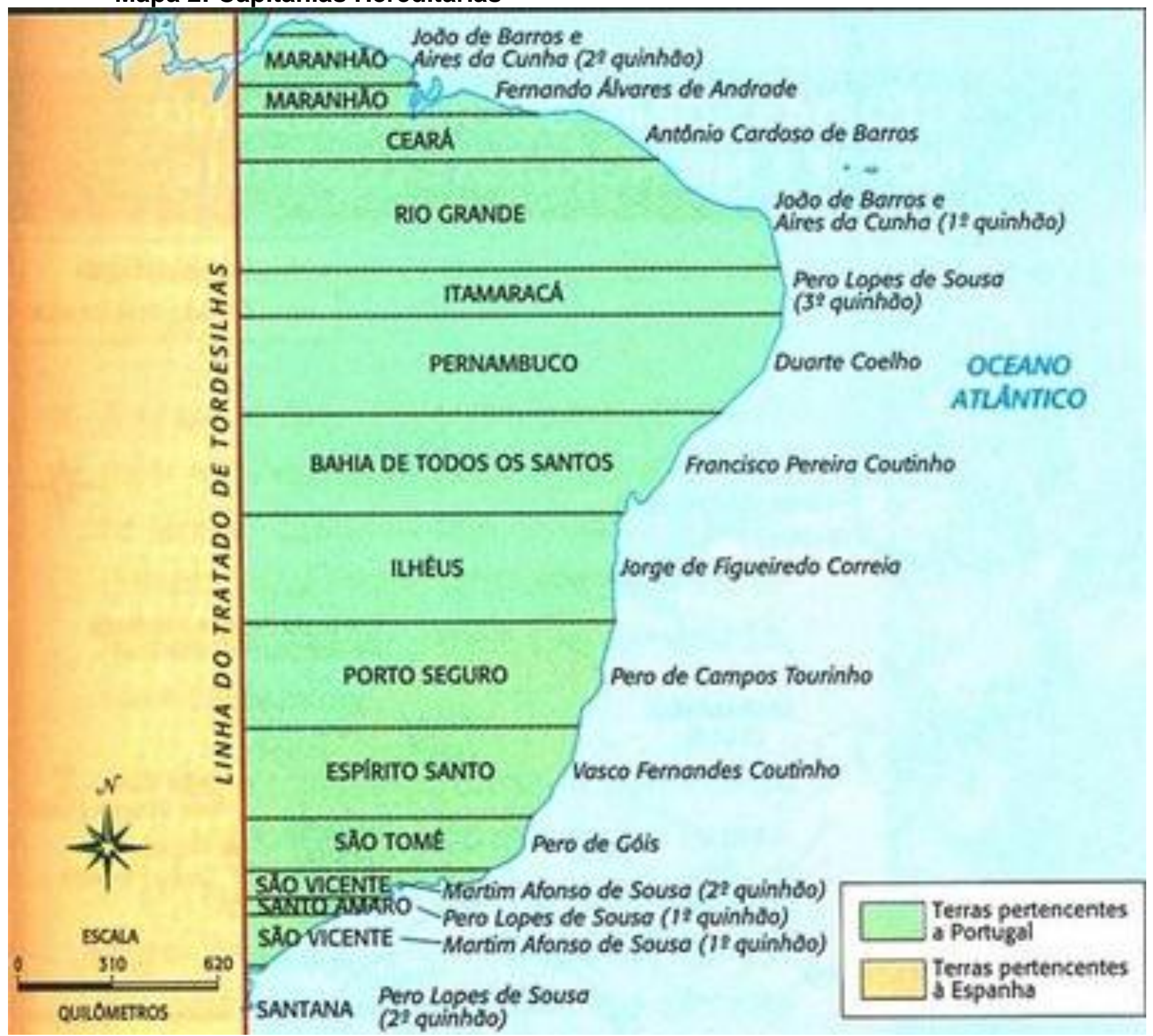

Fonte: $\quad$ http://jchistorybrasil.webnode.com.br/album/periodo-colonial-capianiashereditarias/mapa-das-capitanias-hereditarias-jpg/

Também foram financiadas variadas expedições de exploração e tentativas de garantir a posse das terras.

Com o domínio dos invasores europeus, as terras pertencentes aos índios são apropriadas e demarcadas, se instituindo um uso voltado para a sua exploração.

No Ceará, se destacam as de exploração feita por Pero Coelho, e as de caráter evangelizador e educativo, como a dos padres Francisco Pinto e Luiz 
Figueira ${ }^{14}$. Ambas frustradas pela resistência e defesa dos índios e pela presença de franceses e holandeses que dificultaram a conquista das terras brasileiras e cearenses pelos portugueses (GIRÃO, 1953).

Segundo Girão (1947, p. 60), "a exploração do Ceará teve inspiração mais estratégica ou militar do que econômica e política". No comando dessa empreitada, Pero Coelho foi o responsável por coibir o comércio de estrangeiros e expulsar os franceses já fixados e com estreitas relações com os tabajaras.

Ambas as expedições com tentativas de povoamento tiveram suas falhas e as terras cearenses ficaram no esquecimento oficial, entregues à pirataria estrangeira de franceses, flamengos e ingleses (1947, p. 63), o que permitiu, durante algum tempo, relações de troca e de uso do território, ocasionando mudanças no seu contexto original.

Outra importante figura que esteve em terras cearenses e que empreendeu mudanças na sua fisiografia e nas relações já estabelecidas entre os índios, foi Martins Soares Moreno. Construiu um fortim e travou muitas lutas com a ajuda dos índios, com os quais conseguiu travar amizades. O trabalho desenvolvido por Moreno, com a imprescindível ajuda dos índios, Ihe conferiu a posse como capitãomor da capitania do Ceará por dez anos (Carta-régia de 26 de Maio de 1619).

Nesse período, introduziu a criação de gado e a plantação das canas de açúcar. Gênero de grande valor comercial que daria base para a agricultura e para um novo uso do território.

Com a cultura do açúcar "se iniciará a ocupação efetiva e a colonização do Brasil" (PRADO JR., 1956, p. 32). "Negócio que tem, não como objetivo, mas como objeto o atendimento de necessidades e de um consumo estranhos ao país" (PRADO JR., 1972, p. 37). Nesse arcabouço se constituirá as primeiras bases para um novo modelo socioespacial no território brasileiro. Alicerçado na exploração canavieira, no trabalho forçado dos indígenas e no esfacelamento dos seus modos de vida.

Segundo Ribeiro (1995, p. 74):

Estava-se diante do resultado de um processo civilizatório que, interrompendo a linha evolutiva prévia das populações indígenas

\footnotetext{
${ }^{14}$ Esses padres da companhia de Jesus pretendiam com suas praticas domarem os índios empreenderam na Serra da Ibiapaba, porém a tentativa falhou, pois os índios em defesa dos seus, atacaram a excursão dos padres resultando na morte do padre Francisco Pinto.
} 
brasileiras, depois de subjugá-las, recruta seus remanescentes como mão-de-obra servil de uma nova sociedade, que já nascia integrada numa etapa mais elevada da evolução sociocultural. No caso, esse passo se dá por incorporação ou atualização histórica - que supõe a perda da autonomia étnica dos núcleos engajados, sua dominação e transfiguração -, estabelecendo as bases sobre as quais se edificaria daí em diante a sociedade brasileira. Tais bases se definiriam com claridade com a implantação dos primeiros engenhos açucareiros que, vinculando os antigos núcleos extrativistas ao mercado mundial, viabilizava sua existência na condição socioeconômica de um "proletariado externo", estruturado como uma colônia mercantilescravista da metrópole portuguesa.

No que se refere às tecnologias com que se produziram e reproduziram as condições materiais de existência e a divisão territorial do trabalho, os núcleos coloniais se estabeleceram tendo em suas bases a incorporação e utilização da tecnologia europeia aplicada à produção, ao transporte, à construção e à guerra, com uso de instrumentos de metal e de múltiplos dispositivos mecânicos.

O estabelecimento do engenho de cana, baseado na aplicação de complexos procedimentos agrícolas, químicos e mecânicos, para a produção de açúcar, utilizava-se do trabalho escravo de homens negros, importados como mercadorias em navios, em substituição da escravatura indígena. Também "constituíam organismos completos, fornecendo alimentos, ensino e religião aos seus moradores." (SANTOS, 2008, p.33).

"A interiorização do povoamento foi devida, de um lado, à mineração e, de outro, à criação de gado nas fazendas" (SANTOS, 2008, p.33), responsáveis por fornecer carne e couro, bem como a criação animais de transporte e tração e outros como porcos, galinhas e outros animais domésticos que, associada à lavoura tropical indígena, proveria a subsistência dos núcleos coloniais. (RIBEIRO, 1995, 74).

A relação socioespacial do território brasileiro se reestruturou a partir da substituição da solidariedade elementar fundada no parentesco, característica do mundo tribal igualitário, e por outras solidariedades que propiciaram uma organização com elementos rurais e urbanos, estratificando em classes antagonicamente opostas umas às outras, ainda que interdependentes pela complementaridade de seus respectivos papéis (RIBEIRO, 1995, p. 75). 
No semiárido nordestino, formou-se "uma sociedade pecuarista dominada por grandes latifúndios cujos detentores quase sempre viviam em Olinda ou Salvador" (ANDRADE, 2004, p. 48).

No Ceará, o empreendimento colonial português ocorreu tardiamente, pois, a priori, era considerado um território sem riquezas no que tangia ao interesse do capital mercantil europeu.

\begin{abstract}
Além da inexistência de razões econômicas, também não houve motivos geopolíticos que justificassem maiores investimentos tecnológicos na capitania, fossem relativos à sua defesa ou ao seu povoamento Primeiro, porque a soberania portuguesa na região, desde a expulsão dos holandeses em 1654, já não era ameaçada por estrangeiros; depois, porque, já no Tratado das Tordesilhas, a zona sertaneja do Nordeste do Brasil - e, em nosso caso, o atual território do estado do Ceará já pertencia a Portugal. Além disso, a caminho da região amazônica, era bem mais fácil alcançar-se o Maranhão e o Pará por mar, vindo diretamente de Lisboa, do que cruzando o sertão (JUCÁ NETO, 2012, p. 148).
\end{abstract}

Portanto, sua 're-ocupação' ocorre no século XVII, momento em que a dinâmica espacial foi profundamente modificada, devido às novas formas de uso do espaço geográfico que fez surgir novas estruturas e atividades, como foi o caso do cultivo da cana que propiciou a pecuária; atividade esta que modificou o território cearense como um todo.

A começar sua ocupação nas ribeiras do Rio Jaguaribe e em seguida do Rio Acaraú, locais favoráveis para o estabelecimento de currais e as fazendas iniciais das vilas, sede de controle da economia e da vida social (PINHEIRO, 2008).

A penetração do gado ganhou proporção e fez surgir novos modos de produção no espaço, transformando as relações do todo e criando vinculações entre as áreas. (LIMA, 2011, p.43).

Segundo Jucá Neto (2012, p.135):

[...] a fazenda de gado dispersa no sertão sediou o povoamento. Foi a sede das sesmarias, da unidade familiar, da atividade produtiva e também onde se encontraram as condições propícias para os primeiros sinais de acumulação de renda no sertão. Além disso, foi sede da vida política local, de toda autarquia sertaneja e suas famílias, com poderes quase que absolutos, e da rede de mandos e desmandos que pautou a organização territorial. 
Com o aumento das demandas, as fazendas de gado espalharam-se pelo sertão e deram origem a alguns núcleos, onde mais tarde foi fundada a maioria das vilas (Mapa 3/ Quadro 1) de brancos na capitania do Ceará (JUCÁ NETO, 2012, p.135). 
Mapa 3: ESTADO DO CEARÁ: Municípios que herdaram toponímia das Vilas instaladas no final do século XVIII.

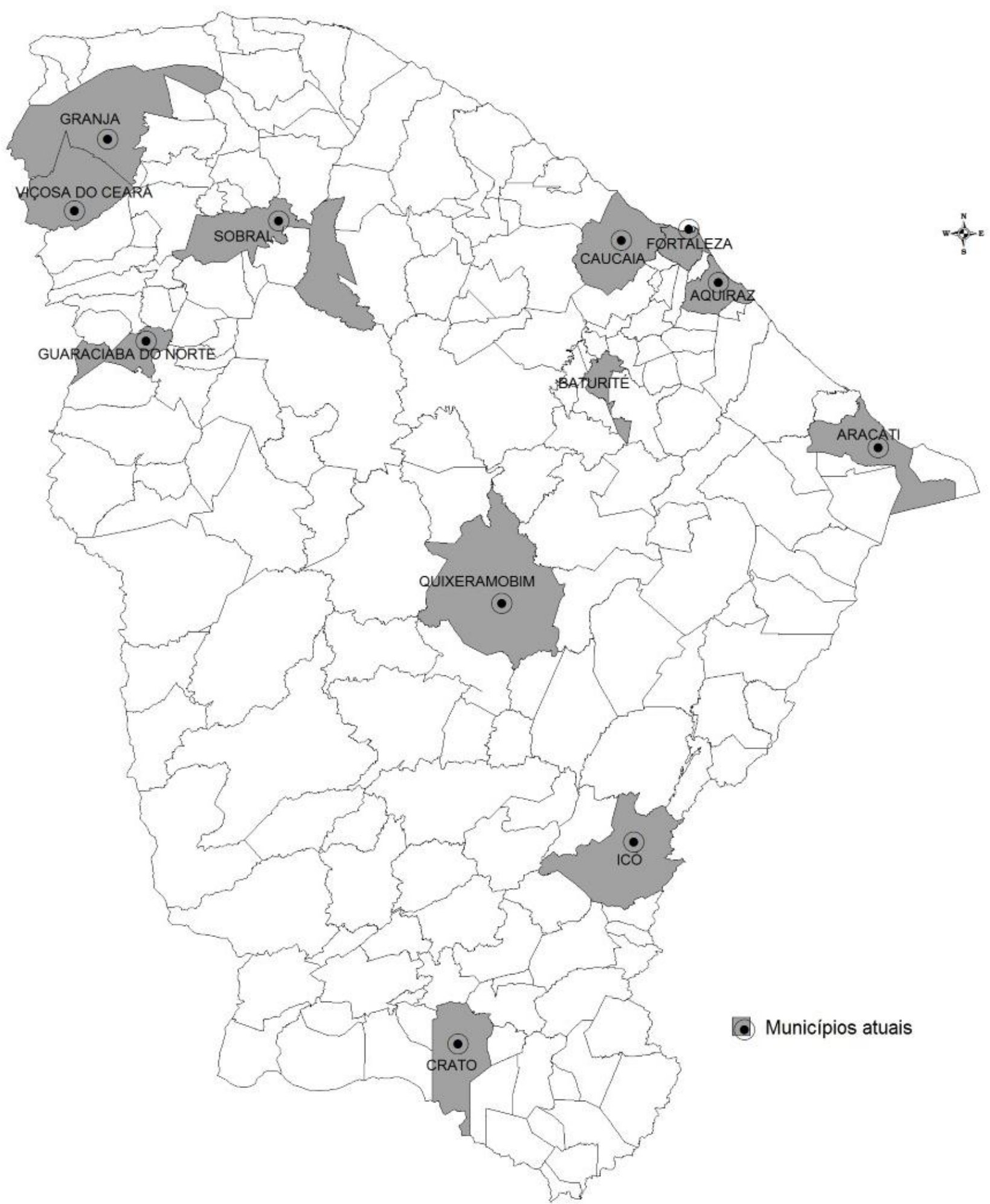

Fonte: Superintendência de Desenvolvimento do estado do Ceará (Adaptação tabela) In: LIMA, 2008, p. 139. Elaboração Cartográfica: Markelly Fonseca de Araujo. Software Maplnfo Professional. 


\section{Quadro 2: Vilas do Ceará no final do século XVIII, por data de instalação}

\begin{tabular}{|l|l|}
\hline \multicolumn{1}{|c|}{ Vila } & \multicolumn{2}{|c|}{ Data de Instalação } \\
\hline Aquiraz & 1713 \\
\hline Fortaleza & 1726 \\
\hline Icó & 1738 \\
\hline Aracati & 1748 \\
\hline Caucaia & 1759 \\
\hline Viçosa do Ceará & 1759 \\
\hline Crato & 1764 \\
\hline Baturité & 1764 \\
\hline Sobral & 1773 \\
\hline Granja & 1776 \\
\hline Quixeramobim & 1789 \\
\hline Guaraciaba do Norte & 1796 \\
\hline
\end{tabular}

Fonte: Superintendência de Desenvolvimento do estado do Ceará In: LIMA, 2008, p. 139.

O crescente número de locais de criação de gado também favoreceu a comercialização em outras regiões, tais como Pernambuco e Bahia; mas a distância entre esses centros de negócio era considerável, o que ocasionava o emagrecimento e perda do rebanho. O fato fez com que os comerciantes passassem a transportar o gado já abatido, transformando-o em carne-seca salgada e couro, surgindo assim, as chamadas charqueadas (GIRÃO, 1953).

As charqueadas proporcionaram movimentação comercial e acúmulo de capital, bem como fez surgir novos objetos e novas relações de trabalho no território, resultando em trocas e uso de novas técnicas para sua produção e comercialização, e por ser uma atividade de grande importância, fez surgir às primeiras práticas da indústria manufatureira. (LIMA, 2011).

Ao final do século XVIII, as crises climáticas, a concorrência e a emergência da industrialização, ocasionada pelo processo iniciado na Inglaterra, foram alguns dos fatores que levaram à desvalorização da carne de charque. $O$ cultivo do algodão passou a ser incentivado no intuito de atender a demanda de matéria-prima para a Inglaterra. 
Esse processo imprime ao território cearense transformações espaciais, pois o espaço geográfico aglutina outras relações, que se dão através de ações e objetos mais diversificados, se tornando a síntese onde dialeticamente interagem os diversos agentes.

\section{As primeiras iniciativas de educação no território}

Os processos que deram origem as primeiras iniciativas de educação no Ceará vinculava-se à colonização do território pela coroa portuguesa no intuito de garantir sua posse, visto que países como a Holanda tinham pretensões em obter também parte desse território (GIRÃO, 1962).

Apesar da tentativa por parte de alguns envolvidos no projeto de levar "educação" aos nativos, - porque se tratava de hereges a catequizar, livrando-os da perdição eterna (RIBEIRO, 1995, p. 70) -, essa ocupação foi marcada pelo uso da violência para efetivação da posse da terra e da produção mercantil baseada na pecuária, resultando na expulsão e morte de muitos nativos, vindo a consolidar-se no início do século XVIII (PINHEIRO, 2008).

Vale ressaltar que a colonização do Brasil, não significou uma ocupação efetiva do território, muito menos a implantação de escolas que pudessem atender a população em geral.

Foi somente no ano de 1808 que parte de seu território, especificamente o Rio de Janeiro, passou por processos de transformação e instalação de equipamentos educativos, culturais e sociais, ficando ainda outras partes renegadas ao abandono. Esse foi também o caso do Ceará, principalmente por estar situado em áreas áridas, com condições climáticas sujeitas à secas periódicas e que não contava com recursos suficientes para a construção e manutenção dos objetos destinados à educação, muito menos oferecia recursos naturais suficientes para maiores investimentos econômicos.

Embora as iniciativas não tenham alcançado o grau de expectativas previstas pela população em geral, não se pode ignorar alguns feitos que colocava em evidência a necessidade de investir na instrução escolar, passando esta a ser pauta de governos com elaboração de leis para o ensino no Brasil, principalmente 
durante as primeiras décadas do século XIX, onde "o Brasil e o Ceará, em particular, sentiam os impactos do processo decorrente da nova dinâmica do capitalismo"; um dos motivos pelos quais a educação passou a ocupar um espaço maior de diálogos no meio político nas décadas que seguem este século e os seguintes.

Em sua constituição, o território do Ceará apresenta, em seu contexto, uma herança histórica permeada de ausências, ações e decisões que pouco favoreceram a educação nesse Estado.

Muitas referências como João Brígido, Tomaz Pompeo de Sousa Brasil, Padre Antonio Vieira, Tristão de Alencar Araripe, dentre outros nomes, fazem análises sobre o território cearense. Porém, de acordo com as historiadoras Sofia Lerche Vieira e Isabel Sabino de Farias (2002), poucos ou inexistentes são os registros sobre o processo inicial de educação, sendo que, só a partir do século XIX, é que se encontram relatórios, leis e resoluções da instrução pública. (VIEIRA; FARIAS, 2002, p. 54).

Alguns relatos e documentos sobre a educação durante o século XVII, apontam uma tentativa frustrada de desenvolver as chamadas missões ${ }^{15}$, pois fatores como o solo, o clima e a resistência dos índios afugentaram os colonizadores de suas terras (VIEIRA; FARIAS, 2002).

A violência foi um traço marcante na ocupação do território cearense, isso ocorreu principalmente pelo uso, que se dava "em função das atividades desenvolvidas e do processo de "limpeza" dos nativos para a efetivação da produção mercantil. Assim, à medida que as terras foram sendo ocupadas pela pecuária, ia-se expulsando indígenas" (PONTES, 2009, p. 18). Isso perdurou até a década de 1720, quando a ocupação da capitania se consolidou com a transformação do território dos indígenas em território da pecuária (PINHEIRO, 2008).

A educação é justificada, então, como um meio de chegar aos donos do território e efetivar a tomada de posse de suas terras. Em outras palavras, o território usado pela educação constitui parte de um projeto de uma geografia do poder como resposta política do desejo de ocupação e monitoramento do território brasileiro e, concomitantemente, o cearense.

\footnotetext{
${ }^{15}$ Instruções através da difusão da fé por meio da educação oral do catecismo, canto e da língua portuguesa.
} 
Todavia, o Ceará, por não oferecer atrativos maiores para a obtenção de lucro, ficou renegado ao descaso, fato esse que repercutiu negativamente no processo de sua constituição no que diz respeito à educação.

Segundo Menezes (1966, p. 350 - 351), "Ainda quando não se iniciara a fixação dos núcleos colonizadores, verifica-se a tentativa dos jesuítas para aldear os índios e educá-los segundo o propósito e a pedagogia dos filhos de Santo Inácio". No Ceará, começaram fracassando na Serra da Ibiapaba, Francisco Pinto, que é morto pelos índios, escapando seu companheiro Luís Figueira, pondo fim a essa missão.

A educação não era julgada necessária, pois as atividades desenvolvidas eram ligadas a terra. Assim, as iniciativas referentes à implementação da educação na colônia apresenta saldo modesto, pois com as reformas pombalinas e a expulsão dos jesuítas, as ações educativas que haviam sido desenvolvidas, seguiram um novo contexto deixando uma lacuna que não foi preenchida com facilidade (MENEZES, 1966, p. 352).

O Ceará, segundo Vieira e Farias "é uma ilustração do descaso para com as capitanias das quais não se extraía lucro" (2002, p. 61). Foi somente depois que se fixaram núcleos urbanos, que se desenvolveram as primeiras iniciativas de educação.

O ensino sofria as imposições de leis e regras do ambiente colonial, que pouco favorecia seu funcionamento. As irregularidades eram notórias. O subsídio literário, verba destinada à educação pública, era insuficiente para a manutenção da educação. Havia irregularidades nos repasses, e os que se encontravam nos cargos de magistério, não tinham instrução suficiente (MENEZES, 1966, p. 352).

No último ano do século XVIII, a carta Régia de 17 de Janeiro separa a capitania do Siará da subordinação do governo geral de Pernambuco. Em termos de aparelhamento, há uma melhora na organização da sociedade em termos de segurança, saúde e organização de leis. Isso decorreu de ações empreendidas pelos agentes econômicos, representantes da Igreja e do Estado português na organização espacial da capitania do Ceará no século XVIII. Para uma melhor capitalização da economia pecuarista, o Estado lusitano fundou vilas em locais estratégicos onde primeiramente se fixaram os sesmeiros e a Igreja (JUCÁ NETO, 2012). 
As escolas públicas existentes contabilizavam apenas duas, O Hospício de Viçosa de 1720 e o Colégio Aquiraz de 1727, instituições responsáveis pela instrução primária e secundária, sendo a última destinada àqueles que optavam pelo sacerdócio (CASTELO, 1970).

O ensino primário particular antecedeu a organização oficial da educação, que ocorreu após a retomada desta pela coroa portuguesa, porém ressalta "que a evolução do ensino, sem sistema, nem método, perduraria de 1759 a 1772, sob o critério de interesses locais, sem recurso ou subvenção" (CASTELO apud SILVA, 2006, p. 198).

O século XIX se inicia e a Constituição Luso-Brasileira de 23 de setembro de 1824 institui a instrução primária gratuita a todos os cidadãos. No currículo, devem ser ensinados os elementos das ciências, belas-letras e artes.

Contudo, a situação do ensino é precária, com professores mal pagos, e mal formados para o exercício do magistério (MENEZES, 1966). Havia escassez de livros e o ambiente escolar não suscitava a necessidade da aprendizagem, ao contrário, trata-se de um local desagradável onde os métodos pedagógicos incluíam o castigo ${ }^{16}$ e a crueldade ${ }^{17}$; frequentavam as escolas crianças maiores de 12 anos, porque não suportavam o regime (MENEZES, 1966).

Segundo Menezes (1966), havia poucos mestres. Entre 1815 a 1841 se contabilizou apenas 56 nomeações de professores de primeiras letras para diferentes localidades de toda a província do Ceará.

Nesse espaço de tempo, tinha-se em 1813, uma população de 149.285 habitantes e em 1850 calculava-se 150.000 habitantes. (MENEZES, 1966).

Vale ressaltar que, nesse mesmo século, o Ceará voltará a estabelecer um sistema educacional regular, que foi normatizado em 1827. (GIRÃO, p. 311).

Essa lei, em seu Art. 4ํㅡㄹ estabelecia a criação de escolas de primeiras letras de ensino mutuo nas capitais das províncias; e também nas cidades, vilas e locais populosos delas em todas as vilas, cidades e locais mais populosos do império. Dizia o Art $2^{\circ}$ :

\footnotetext{
${ }^{16}$ O Art 15ำ cita: "Estas escolas serão regidas pelos estatutos actuaes no que se não opuserem á presente lei; os castigos serão os praticados pelo methodo de Lencastre" (IMPÉRIO DO BRASIL, 1827).

${ }^{17}$ Usa-se a palmatória e o número de bolos variava numa escala escandalosa, em algumas situações havia o flagelo com chicote. (MENEZES, 1966, p. 354).
} 
Os Presidentes das províncias, em Conselho e com audiencia das respectivas Camaras, emquanto não tiverem exercicio os Conselhos geraes, marcarão o numero e localidades das escolas, podendo extinguir as que existem em logares pouco populosos e remover os Professores dellas para as que se crearem, onde mais aproveitem, dando conta á Assembléa Geral para final resolução. (COLEÇÕES DE LEIS DO IMPÉRIO DO BRASIL, 1827).

Em seus Art. $5^{\circ}$ e $7^{\circ}$ discutia a aplicação dos recursos e exames para a ocupação dos cargos de professores:

Para as escolas do ensino mutuo se applicarão os edifficios, que houverem com sufficiencia nos logares dellas, arranjando-se com os utensillios necessarios á custa da Fazenda Publica e os Professores; que não tiverem a necessaria instrucção deste ensino, irão instruir-se em curto prazo e á custa dos seus ordenados nas escolas das capitaes. (Art. 5 - COLEÇÕES DE LEIS DO IMPÉRIO DO BRASIL, 1827).

Os que pretenderem ser providos nas cadeiras serão examinados publicamente perante os Presidentes, em Conselho; e estes proverão o que fôr julgado mais digno e darão parte ao Governo para sua legal nomeação. (Art. $7^{\circ}$ - COLEÇÕES DE LEIS DO IMPÉRIO DO BRASIL, 1827).

Porém, a criação de escolas, bem como a contratação de professores não acompanhou o aumento e o desenvolvimento populacional, muito menos uma educação que tivesse uma formação completa, com ensinamentos úteis à vida em sociedade e a valorização das relações de formação e respeito humano. O que é possível constatar no Art. 6ํㅜ e $12^{\circ}$ que versam sobre os conteúdos do ensino:

Os Professores ensinarão a ler, escrever as quatro operações de arithmetica, pratica de quebrados, decimaes e proporções, as nações mais geraes de geometria pratica, a grammatica da lingua nacional, e os principios de moral christã e da doutrina da religião catholica e apostolica romana, proporcionando a comprehensão dos meninos; preferindo para as leituras a Constituição do Imperio e a Historia do Brazil. (COLEÇÕES DE LEIS DO IMPÉRIO DO BRASIL, 1827).

As mestras, além do declarado no art 6ำ, com exclusão das noções de geometria e limitando a instrucção da arithmetica só as suas quatro operações, ensinarão tambem as prendas que servem á economia domestica; e serão nomeadas pelos Presidentes em Conselho, aquellas mulheres, que sendo brazileiras e de reconhecida honestidade, se mostrarem com mais conhecimentos nos exames feitos na fórma do art. $7^{\circ}$. 
Neste aspecto, Menezes (1966) faz uma critica à preocupação em formar uma determinava classe, nomeada por ele de "elite bacharelícia", a população crescia e, continuava a viver mal e sem instrução ${ }^{18}$.

A isso se vinculam as atividades que a maioria pobre exercia, as quais estavam ligadas à agricultura e pecuária e que, ao entender das classes dominantes, não requeriam conhecimentos mais aprofundados para exercê-las.

Esse modelo de educação perpassa anos e transcorre obedecendo praticamente ao mesmo modelo de implementação. O número de analfabetos era grande e o ensino não assegurava a sua diminuição.

Destaca-se que a passagem do Império para a República representou, no âmbito da educação, uma orientação pedagógica desvinculada da pedagogia jesuítica, o ensino passou a ser leigo e ministrado nos estabelecimentos públicos, ainda que, não ocupando uma função obrigatória (Carta de 1891, no capítulo sobre a "Declaração dos Direitos").

O saldo de iniciativas de tentar empreender a educação é modesto; estudos apontam um reduzido número das iniciativas na província do Ceará até 1840 . Fazendo um balanço, Pires de Almeida apresenta os seguintes dados:

\section{Quadro 3: Iniciativas de ensino primário na Província do Ceará}

\begin{tabular}{|l|l|l|l|}
\hline Localidade & Escolas & Cadeiras & Data de fundação \\
\hline $\begin{array}{l}\text { Aquiras ou São } \\
\text { José do Ribamar }\end{array}$ & Primária & - & Antiga \\
\hline Aracati & 2 Primárias (masc. e fem.) & Latim & - \\
\hline $\begin{array}{l}\text { Baturité (Monte Mor) } \\
\text { Velho }\end{array}$ & Primária & - & Fundada pelos Jesuítas \\
\hline $\begin{array}{l}\text { Campo Mor de Quixe- } \\
\text { Ramobim }\end{array}$ & Primária & Latim & - \\
\hline Crato & 2 Primárias (masc. e fem.) & $\begin{array}{l}\text { Latim } 25 \text { de junho de } \\
1831\end{array}$ & \\
\hline Fortaleza & Primária & - & Fundação antiga \\
\hline & & $\begin{array}{l}\text { Retórica, } \\
\text { Geometria, } \\
\text { Filosofia e Francês }\end{array}$ & 25 de julho de 1831 \\
\hline Icó & & & - \\
\hline Januária (Sobral) & $\begin{array}{l}\text { Primárias masc. } \\
\text { Primárias fem. }\end{array}$ & & 1883 \\
\hline Sant'Ana & Primária & & 1839 \\
\hline
\end{tabular}

Fonte: PIRES de ALMEIDA apud VIEIRA; FARIAS, 2002, p. 104.

\footnotetext{
${ }^{18}$ A estimativa média da população era de 200.000 habitantes, dados calculados pelos avaliadores Belfort em 1928 e Alencar em 1835, o número de analfabetos era grande. (MENEZES, 1966, p. 355). O autor faz essa leitura a partir da situação do ensino em 1835: 29 cadeiras para ensino de primeiras letras, 6 para o ensino de gramatica latina, 3 cadeiras com professores de retórica, geometria e francês (na Capital, em Aracati, Sobral, Icó, Crato e Quixeramobim).
} 
Não obstante, a forma de ocupação do território, para fins de desenvolvimento da pecuária (PONTES, 2009), a ausência do poder público e o pouco conhecimento dos mestres, têm ainda hoje repercussões negativas na educação cearense.

No transcorrer da primeira metade do século XIX, a educação cearense pouco avançou em relação aos anos anteriores, as poucas escolas que haviam, voltavam-se para uma formação intelectual e privilegiavam os filhos das elites, "não apenas porque seu número era reduzido mas, também, pelos custos que representavam para uma população de pobres recursos" (VIEIRA; FARIAS, 2002).

Segundo Darcy Ribeiro (1995), a sociedade brasileira concomitantemente integrou cultura letrada a uma minoria da população e condenou um número expressivo à exclusão.

A divisão em classes antagônicas, estratificada e intencionalmente formada, congregava, de um lado, ricos, um minúsculo estrato social de letrados, enquanto reflexo da instrução baseada nos costumes patrícios e cosmopolitas que, através do domínio do saber erudito e técnico europeu de então, orienta as atividades mais complexas e opera como centro difusor de conhecimentos, crenças e valores dos dominadores e, de outro, os pobres, que permanecia com um saber vulgar, a ignorância e os hábitos arcaicos dos dominados (RIBEIRO, 1995, p. 211).

Esse foi o caso das classes sociais que não dispunham de meios para educar seus filhos, bem como os excluídos desse processo, como negros, índios e a grande maioria pobre. Portanto, as melhores possibilidades do uso do território se realizavam com maior intensidade e frequência por uma minoria, ou seja, pelos mais privilegiados política e economicamente.

No Ceará, esse processo ocorreu de forma mais complicada e bem pior, pois além da exclusão de cunho cultural, ainda era um Estado pobre que concentrava um sistema de ensino em pontos onde a economia era mais pungente, ficando o restante do território desprovido do acesso à educação.

Deste modo, os que dispunham de recursos se deslocavam para a província de Pernambuco ou frequentavam o Liceu ${ }^{19}$ (Foto 2), escola que teve forte relevância, pois, a partir dela "é que passa a existir uma escola secundária no mais próprio sentido do termo" (VIEIRA; FARIAS, 2002, p. 110).

\footnotetext{
${ }^{19}$ Criado em 1844 e regulamentado em 1845.
} 
Foto 2: Liceu do Ceará

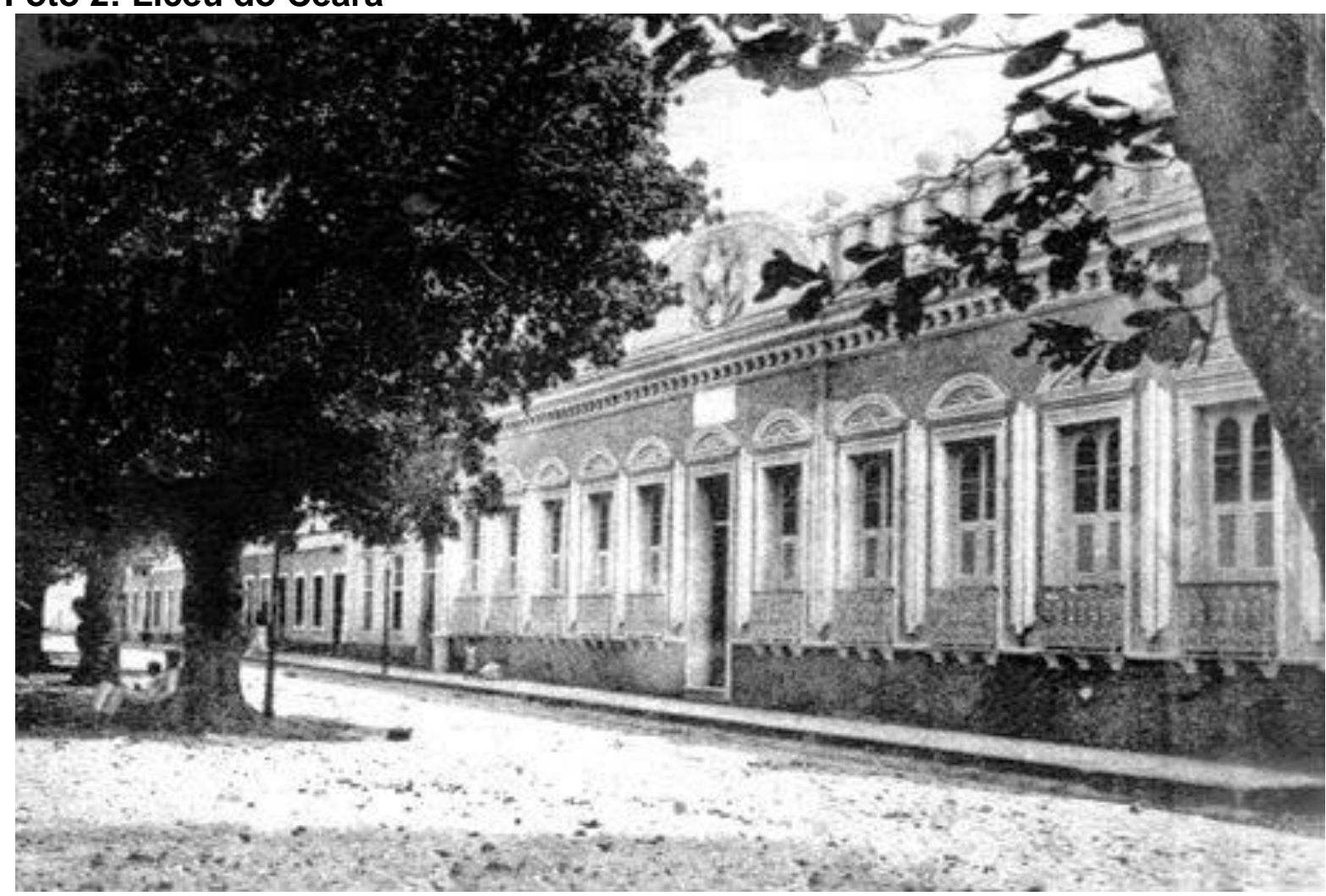

Fonte: http://www.fortalezaemfotos.com.br/2014/04/colegios-de-fortaleza-no-seculoxix.html, Século XIX.

Além disso, esta também foi determinada a partir da seletividade geográfica, limitada praticamente ao ensino primário e secundário, continuava a ser ofertada nas áreas onde havia produção, maiores densidades e escoamento de produtos. É o caso de Fortaleza, Aracati, Icó, Camocim, Sobral, Acaraú (Mapa 4). 
Mapa 4: ESTADO DO CEARÁ: Municípios com Centro Econômico e Porto na primeira metade do século XIX.

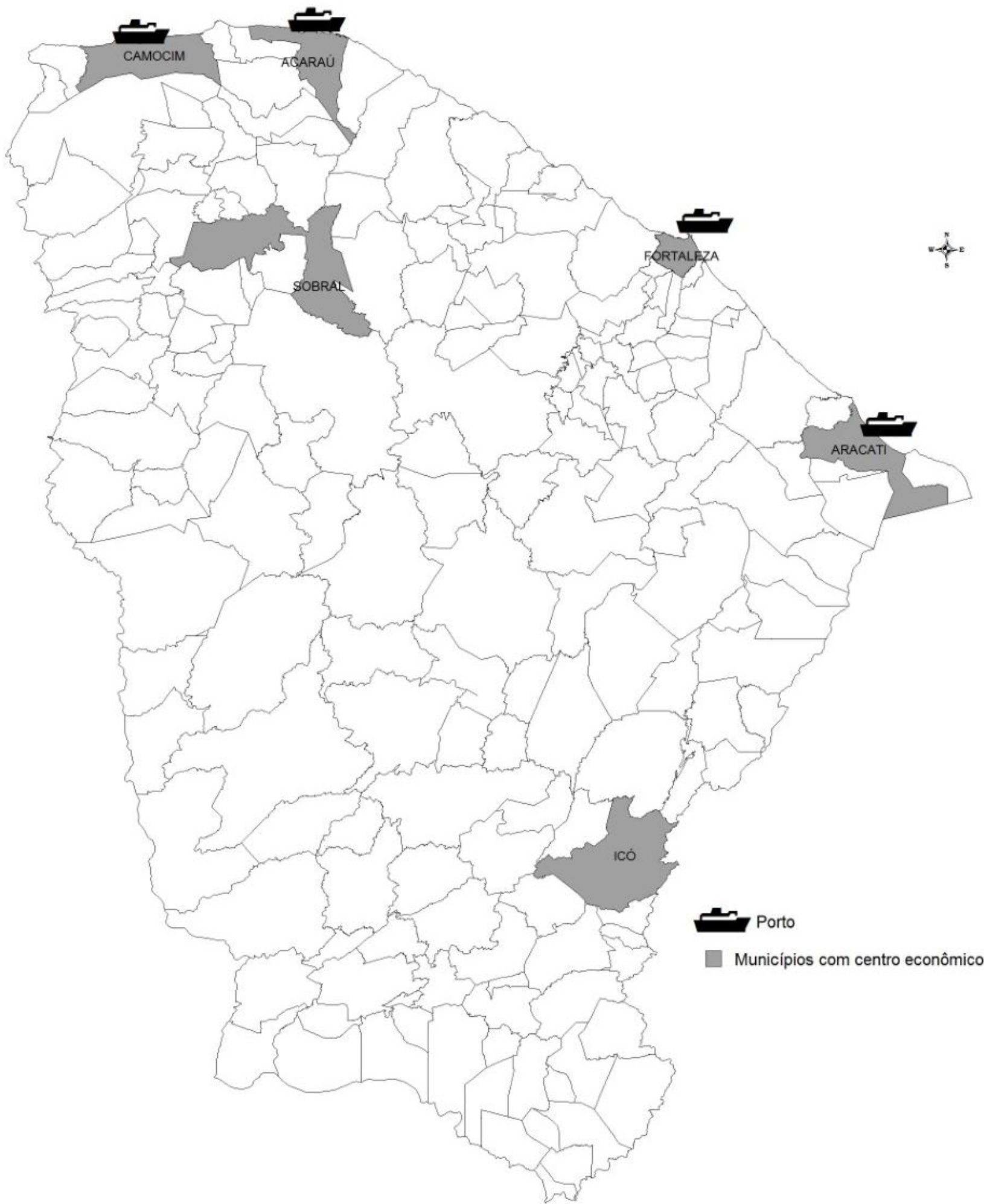

Fonte: Superintendência de Desenvolvimento do estado do Ceará (Adaptação tabela) In: LIMA, 2008, p. 158. Elaboração Cartográfica: Markelly Fonseca de Araujo. Software Maplnfo Professional. 
Com relação às especificações das atividades comerciais e de trocas (Quadro 4), estas estavam organizadas da seguinte forma :

Quadro 4: Principais centros econômicos do Ceará na primeira metade do
século XIX:
\begin{tabular}{|l|l|}
\hline Centro & \multicolumn{1}{|c|}{ Especificação de atividades } \\
\hline Sobral & $\begin{array}{l}\text { Centro comercial que polariza intensamente a produção da região Norte, } \\
\text { abastecendo-a em sua quase totalidade. }\end{array}$ \\
\hline Fortaleza & $\begin{array}{l}\text { Porto, centro comercial polarizador de Aquiraz e periferia e ainda parte de } \\
\text { Baturité, exportando produção destas regiões e abastecendo a periferia. } \\
\text { Importante abastecedor de Recife e São Luís. }\end{array}$ \\
\hline Aracati & $\begin{array}{l}\text { Porto, centro comercial que polariza o Jaguaribe e exporta produtos de Russas, } \\
\text { Quixeramobim, Icó e uma parte de Baturité e Pereiro. }\end{array}$ \\
\hline Icó & $\begin{array}{l}\text { Centro comercial que inicia o desenvolvimento do seu próprio comércio e } \\
\text { continua distribuindo para parte de Cariri as mercadorias vindas do Aracati. }\end{array}$ \\
\hline Camocim (1) & $\begin{array}{l}\text { Porto, centro comercial que exporta a produção de Granja e importa mercadorias } \\
\text { de Recife e São Luís. }\end{array}$ \\
\hline Acaraú (2) & $\begin{array}{l}\text { Porto, centro comercial que exporta a produção de Sobral, Uruburetama e } \\
\text { Meruoca e importa mercadorias de Recife e São Luís. }\end{array}$ \\
\hline
\end{tabular}

Fonte: Superintendência de Desenvolvimento do estado do Ceará In: LIMA, 2008, p. 158.

Segundo Santos (2000, p. 4), "foi, talvez, a combinação de dois fatores principais: a localização do poder político-administrativo e a centralização correspondente dos agentes e das atividades econômicas que criou as primeiras necessidades de contar com escolas, nessas terras longínquas".

Ao terminar o século XIX, o Ceará tinha uma população de 849.118 habitantes, o governo contava com um orçamento instável; as secas que se sucederam forçaram medidas de economia que comprometeram a construção de obras e a funcionalidade das instituições já existentes (ALVES, 1966).

Devido aos problemas existentes no estado, foram extintas 77 escolas primárias, pela Lei n. 587 de julho de 1900, e mais 13, por ato de 5 de junho de 1901. Das 336 escolas que funcionavam em 1900, ficaram 246, "isso em consequência da crise climática que devastou o Ceará naquele ano". (ALVES, 1966, p. 362).

As dificuldades eram crescentes e as fontes de rendas do Estado eram desorganizadas, não podendo atender as necessidades da população como um todo. Além disso, o presidente da República não atentou para a situação de flagelo na qual se encontrava o Ceará (ALVES, 1966).

Florestan Fernandes (1971, p. 414), quando se refere à educação brasileira como um todo, diz que: 
no conjunto, os problemas educacionais, resolvidos de forma insatisfatória no passado ou nascido com a dinâmica da própria situação histórico-social no presente, tiveram que ser enfrentados com recursos deficientes e obsoletos, além disso mal aproveitados, em virtude da mentalidade prática predominante, que incentivava seja a busca de soluções improvisadas, seja o abandono delas a um destino quase sempre ingrato, devido às influências conservantistas de vários círculos e instituições sociais.

Nessa transformação dos usos do território brasileiro, pouco se avançou na garantia de direitos, ou no fortalecimento de instituições que servissem ao funcionamento de uma democracia de fato, ou que visassem fortalecer as horizontalidades, no intuito de propiciar melhorias para a população em geral com a criação de emprego e renda a partir das localidades. O que predominaram foram políticas que garantiram vantagens das elites sobre as classes populares.

"Faltaram-nos recursos materiais, humanos e culturais para empreendermos modificações rápidas e profundas no sistema educacional existente" (FERNANDES, 1971, p. 124). Na esfera pedagógica, não se obteve sucesso, não adequou-se a vida prática nos campos político, intelectual e econômico; ao contrário, continuou a se multiplicarem os estabelecimentos para distribuir a cultura geral aristocrática (FERNANDES, 1971).

Esse fato perpassou o século XIX, e a educação passou longe de ser prioridade, sendo seu acesso limitado a uma pequena parcela da população, ou seja, a classe rica e dominante.

No geral, a constituição do território cearense se deve, sobretudo, a uma economia de produção que girou em torno de atividades agrícolas, comerciais, administrativas, industriais e de serviços. Iniciou-se com a pecuária, a qual desencadeou um fluxo comercial e de serviços, a partir de seus produtos. Seguida, pela cultura do algodão, que contribui para a instalação da proto-indústria ${ }^{20}$, no contexto de uma organização industrial mais alinhada aos pressupostos comerciais no âmbito internacional.

As mudanças que se processavam eram decorrentes do processo que envolvia ações voltadas para garantir o desenvolvimento dos novos modos de produção com a implantação de novos objetos no território, pautados no

\footnotetext{
${ }^{20}$ Proto-industrialização foi marcado pelo crescente envolvimento das famílias agrárias na produção artesanal orientada para o mercado.
} 
desenvolvimento dos processos produtivos, no conhecimento e nas técnicas aplicáveis às inovações, bem como a concentração populacional em determinadas localidades, devido às novas demandas territoriais que surgiam.

Esse conjunto de fatores impulsionava ações para atender as variadas formas de uso do território que agregava uma dinâmica de crescimento da população, bem como, problemas para equilibrar tal crescimento e a sua manutenção pelo Estado, provendo-Ihe meios de sobrevivência.

Nesse contexto, de acordo com Castelo (1970), foi pensado o ensino profissional, que no ano de 1856 instalou a Casa de Educandos, mais tarde Colégio, criado para meninos órfãos de desvalidos em idade de 7 a 18 anos, internos até completarem 20 anos. Nesse ambiente, aprendiam leitura e escrita, gramática nacional, música e ofício de ferreiro, alfaiate, etc.

Mas ressalta-se que esse tipo de ensino só foi oficialmente normatizado com a Escola de Aprendizes e Artífices, em 1910, por iniciativa de Nilo Peçanha que criou uma escola profissional em cada Estado (CASTELO, 1970).

A escola de ofício contava com um modelo de formação estritamente direcionada para uma profissão que oferecia uma educação manufatureira, ensino que encaminhava tanto para o trabalho artesanal como para a produção industrial (CUNHA, 2000).

No início do século XIX, em detrimento da demanda assegurada, das possibilidades naturais para a produção e da ausência de outras fontes de riqueza, o algodão torna-se a principal atividade do cearense (GIRÃO, 1953), sendo exportado para a Inglaterra, que consumia grande parte do que era produzido no Ceará e em todo o Nordeste (LIMA, 2011).

No Ceará, constitui-se o binômio gado-algodão, alterando as relações de trabalho e a paisagem dos espaços cearenses, com a construção de vias de acesso que ligavam o interior ao litoral, através das estradas que se abrem de Fortaleza para as zonas interioranas, garantindo o escoamento da produção da Capitania.

Provoca assim o súbito desenvolvimento dos meios de transporte, assegurando de modo compensador o exercício da atividade agrícola; colocando pela primeira vez a sede administrativa em condição de se impor às demais vilas cearenses como verdadeiro centro político, econômico e social da Capitania. Surgem outros pólos comerciais como no caso de Icó. (GIRÃO, 1996, p. 88). 
Desse modo, a produção de algodão, que iniciou-se nas imediações de Fortaleza e Uruburetama (FERREIRA NETO apud LIMA, 2011, p. 57), foi se expandindo pelo Ceará, abrangendo a bacia do Jaguaribe, Icó, Sobral e Aracati na região do Baixo Jaguaribe (PRADO JÚNIOR; NOBRE apud LIMA, 2011, p. 58).

Segundo Oliveira (1981, p.46), o cultivo do algodão do Nordeste surge nessa Região mediante a Revolução Industrial e,

[...] particularmente, do avanço da indústria têxtil na economia inglesa, a demanda mundial do algodão começa crescer espontaneamente... O Nordeste agrário não-açucareiro converte-se num vasto algodoal, desde o Maranhão à Bahia. Não é a "plantation", porém a estrutura de produção dessa nova mercadoria, esse vasto algodoal é na verdade constituído pela segmentação sem fim de pequenas e isoladas culturas. A rapina internacional encontra terreno propício à constituição de uma estrutura de produção em que o capitalismo internacional domina a esfera financeira de circulação, deixando a produção entregue aos cuidados de fazendeiros, sitiantes, meeiros, posseiros. Emerge aqui a estrutura fundiária típica do latifúndio. O fundo de acumulação é dado pelas "culturas de subsistência" do morador, do meeiro, do posseiro, que viabilizam, por esse mecanismo um baixo custo de reprodução de força de trabalho e portanto um baixo valor que é apropriado à escala de circulação internacional de mercadorias sob a égide das potências imperialistas (OLIVEIRA, 1981, p. 46-47).

A partir da segunda metade do século XIX, a produção torna-se mecanizada. São instaladas usinas açucareiras e, anos depois, estradas de ferro. "Às técnicas da máquina circunscritas à produção sucedem as técnicas da máquina, incluídas no território" (SANTOS, 2000, p. 5).

O Ceará incorpora os novos objetos provenientes do período técnico, respondendo às novas "necessidades" materiais que são criadas a partir do acúmulo das técnicas do passado e da divisão do trabalho no processo de desenvolvimento desigual e combinado.

A partir da eficácia da técnica ${ }^{21}$, a sua incorporação e as novas "necessidades", o grande mercado se abre para essa matéria-prima; tem-se inicio a fase preliminar da indústria têxtil, que constituiria as bases para atividades indutoras

\footnotetext{
${ }^{21}$ No seu estudo sobre a técnica no livro Meditação da técnica: Vicissitudes da ciência, cacofonia na física, Ortega y Gasset diz que "os atos técnicos são específicos do homem sendo o seu conjunto a técnica, definida como a reforma que o homem impõe à natureza em vista da satisfação de suas necessidades, que por sua vez são impostas pela natureza ao homem e este responde impondo-lhe uma mudança" (ORTEGA Y GASSET, 1963, pp. XI).
} 
de outros serviços e produtos, propiciando as condições para configuração das atividades econômicas de cunho industrial.

As áreas produtoras de algodão deram subsídios ao surgimento das indústrias têxteis para consumir o excedente da produção e diminuir os efeitos da crise que se instalara com o término da Guerra da Secessão ${ }^{22}$. "A expansão do ramo têxtil possibilitou a implantação de indústrias de óleos vegetais que passaram a fornecer também matérias-primas para as indústrias de produtos alimentares e de sabão" (BAIMA, 1989, p. 118), fazendo com que se criasse uma interdependência entre esses setores (BAIMA, 1989).

A cultura algodoeira no Ceará favoreceu a indústria têxtil que se estendeu até o final da década de 1950, e caracterizou-se pelo predomínio dos investimentos locais de iniciativa individual ou de grupos familiares, porém com incentivos financeiros do governo para efetivar a implantação das indústrias (BAIMA, 1989).

${ }^{22}$ Durante a Guerra da Secessão, a produção de algodão no Nordeste se intensificou devido à demanda externa. Ao término da guerra, reorganizada a economia dos Estados Unidos, esse produto perdeu espaço no mercado para esse país. 
CAPÍTULO 2

\section{MODERNIZAÇÃO, INDUSTRIALIZAÇÃO E O APOGEU DA EDUCAÇÃO PROFISSIONAL}

O capítulo 2 discute o Ceará no contexto da formação de um mercado interno, tendo inicialmente o uso do território pela cultura do algodão, subsidiando a instalação de novas infraestruturas, viabilizando a expansão e a criação de novas relações socioterritoriais. Somado a isso, novas demandas provenientes das mudanças que se processavam, aparecem, induzindo o surgimento de instituições de ensino que pudessem atendê-las, como é o caso das escolas voltadas para novas modalidades de ofertas, ou seja, as escolas profissionais. Estas, ao longo do processo de industrialização e modernização no território usado cearense, ganham novas refuncionalizações à medida que novos objetos e ações induzem mudanças. 


\title{
Capítulo 2. Modernização, Industrialização e o apogeu da Educação Profissional
}

\begin{abstract}
"Tudo, nos séculos, transformou-se incessantemente. Só ela, a classe dirigente, permaneceu igual a si mesma, exercendo sua interminável hegemonia. Senhorios velhos se sucedem em senhorios novos, super-homogêneos e solidários entre si, numa férrea união superarmada e a tudo predisposta para manter o povo gemendo e produzindo. Não o que querem e precisam, mas o que lhes mandam produzir, na forma que impõem, indiferentes a seu destino.

Não alcançam, aqui, nem mesmo a façanha menor de gerar uma prosperidade generalizável à massa trabalhadora, tal como se conseguiu, sob os mesmos regimes, em outras áreas. Menos êxito teve, ainda, em seus esforços por integrar-se na civilização industrial. Hoje, seu desígnio é forçarnos à marginalidade na civilização que está emergindo." (RIBEIRO, 1995, p.69).
\end{abstract}

No Ceará, as bases para a formação de um mercado interno são reforçadas pela cotonicultura e pela civilização do couro. Consorciada com a pecuária e a agricultura de subsistência, o algodão induz a instalação de novas infraestruturas, viabilizando uma adequação espacial à sua produção e expansão, e resultando numa nova divisão do trabalho, mais complexa e ainda pouco conhecida (LIMA, 2006 apud LIMA, 2011).

A ampliação da agricultura comercial do algodão imprime novas relações de poder, "o Estado passa a assumir muitas funções, antes concentradas nas mãos dos coronéis, dos senhores de terras e das gentes" (NEVES, 2007, p.1).

O algodão coloca o Ceará no comércio internacional e, no final do século XIX, o advento da indústria, espacializando o progresso técnico, impõe novas relações socioeconômicas no território.

Em meio às mudanças que se processavam advindas da cotonicultura, alteravam-se as relações no campo, a cultura do algodão ampliou as áreas destinadas ao mercado externo, o que restringiu os espaços a serem ocupados pelos camponeses. Outro fator relevante foi a criação da lei de terras de 1850, que 
determinava um valor monetário estimado e a limitação dos espaços que a terra deveria ter (NEVES, 2001).

O Ceará, porém, era permeado de contradições, expropriações e desigualdades que se agravavam mediante às formas de uso do território, que se voltava cada vez mais ao fortalecimento das relações de poder e controle econômico por uma elite que também governava essas terras.

A literatura e as publicações desse período estão repletas de contos, artigos, livros e narrativas que dão testemunho das relações que se estabeleciam mediante as mudanças que se impunham ao território ${ }^{23}$. Muitas fazem menção à seca, como um dos fatores determinantes para as reconfigurações territorial do Ceará e do Brasil, bem como seu uso para angariar trocas de favores e permanência no poder.

A seca alavancou a fuga do campo para pontos do litoral, especialmente para a capital.

\begin{abstract}
A reação das autoridades e da população urbana foi de perplexidade! Sem planejamento, surpresos, os dirigentes buscavam meios de manter os retirantes fora da cidade, seja em obras públicas na periferia (com a estrada de ferro de Baturité) ou seja embarcando-os para a Amazônia. Inútil! A chegada diária dos retirantes impressionava pelo número, pela miséria e pelo deplorável estado de saúde. (NEVES, 2000, p. 82).
\end{abstract}

Para amenizar a situação, as autoridades tentaram manter sob algum controle, dividindo-os em distritos, com o objetivo de prestar atendimento médico, distribuir comida e alistar para o trabalho (NEVES, 2000).

No contexto dos trabalhos, estavam o calçamento de ruas, a construção da estrada de ferro de Baturité e as atividades relacionadas à construção de ferrovias. "Homens, mulheres e crianças trabalhavam continuamente para receber sua ração de comida. Qualquer falta ou reclamação era motivo para exclusão da lista de pagamento" (NEVES, 2000, p. 82).

Sabe-se que foram determinações políticas de prioridades, que privilegiaram uma pequena parcela de pessoas e condenaram um número muito maior a viver na pobreza. Pois as iniciativas tanto do setor público quanto do privado não eram suficientes para atender a todos. Crescia o número de doentes, a violência se tornou eminente e os conflitos se tornaram constantes.

\footnotetext{
${ }^{23}$ Ver: O Sertanejo (1875), de José de Alencar, Os Retirantes (1879), de José do Patrocínio, Vidas Secas (1938), de Graciliano Ramos, dentre outros.
} 
De qualquer forma, a seca marca a cultura cearense e provoca significativas mudanças determinando novas relações políticas e sociais, pois gerou ações estatais para amenizar os seus efeitos no território. Técnicos e estudiosos foram contratados para encontrar soluções hidráulicas, para a fixação do homem no campo e para projetar locais de atração com obras públicas de construção de poços, barragens e açudes, bem como, campos de fixação ${ }^{24}$, no intuito de evitar novas 'invasões' e ocupações na capital (NEVES, 2000).

Vê-se, nesse período, que a educação ainda não era prioridade, pois os problemas sociais cresciam exponencialmente, e as soluções pouco alcançavam a maioria da população. Portanto, o seu acesso continuava a ser destinado a uma classe privilegiada da população, ou seja, a elite.

Também esta é determinada a partir da seletividade geográfica, limitada praticamente ao ensino primário e secundário, e continuava a ser ofertada nas áreas onde havia produção, maiores densidades e escoamento de produtos. É o caso de Fortaleza, Aracati, Crato, Sobral, Quixadá, Baturité.

Nesses locais, os novos objetos técnicos imprimiam ao território novas formas-conteúdos, trazendo com isso novas demandas, enquanto a educação escolar se torna o principal meio de suprir essas demandas.

Nesse cenário, a educação cearense é assinalada pelo surgimento de instituições de ensino que pudessem atender as novas demandas por educação, provenientes das mudanças que se processam no território, como é o caso das escolas voltadas para novas modalidades de ofertas, ou seja, as escolas profissionais.

Nesse quesito, está a Escola Normal (Foto 3), que objetivava, sobretudo, a formação de professores. O curso ofertado, em sua fase inicial, tinha caráter profissionalizante, e tinha como base uma organização curricular propedêutica, centrada nas grandes áreas do conhecimento (VIEIRA; FARIAS, 2002).

\footnotetext{
${ }^{24}$ Os campos espalhados pelo território cearense eram uma espécie de curral que abrigavam retirantes, onde se se distribuíam alimentos de forma racional e prestava algum atendimento aos doentes no intuito de evitar os conflitos provocados pelo presença em massa de pessoas que fugiam para a capital; Foram alocados em Crato, Carius, Quixeramobim, Ipu, Senador Pompeu, concentravam milhares de retirantes, em Crato chegou a acolher cerca de 90.000 habitantes.
} 
Foto 3: Escola Normal Pedro II - 1884

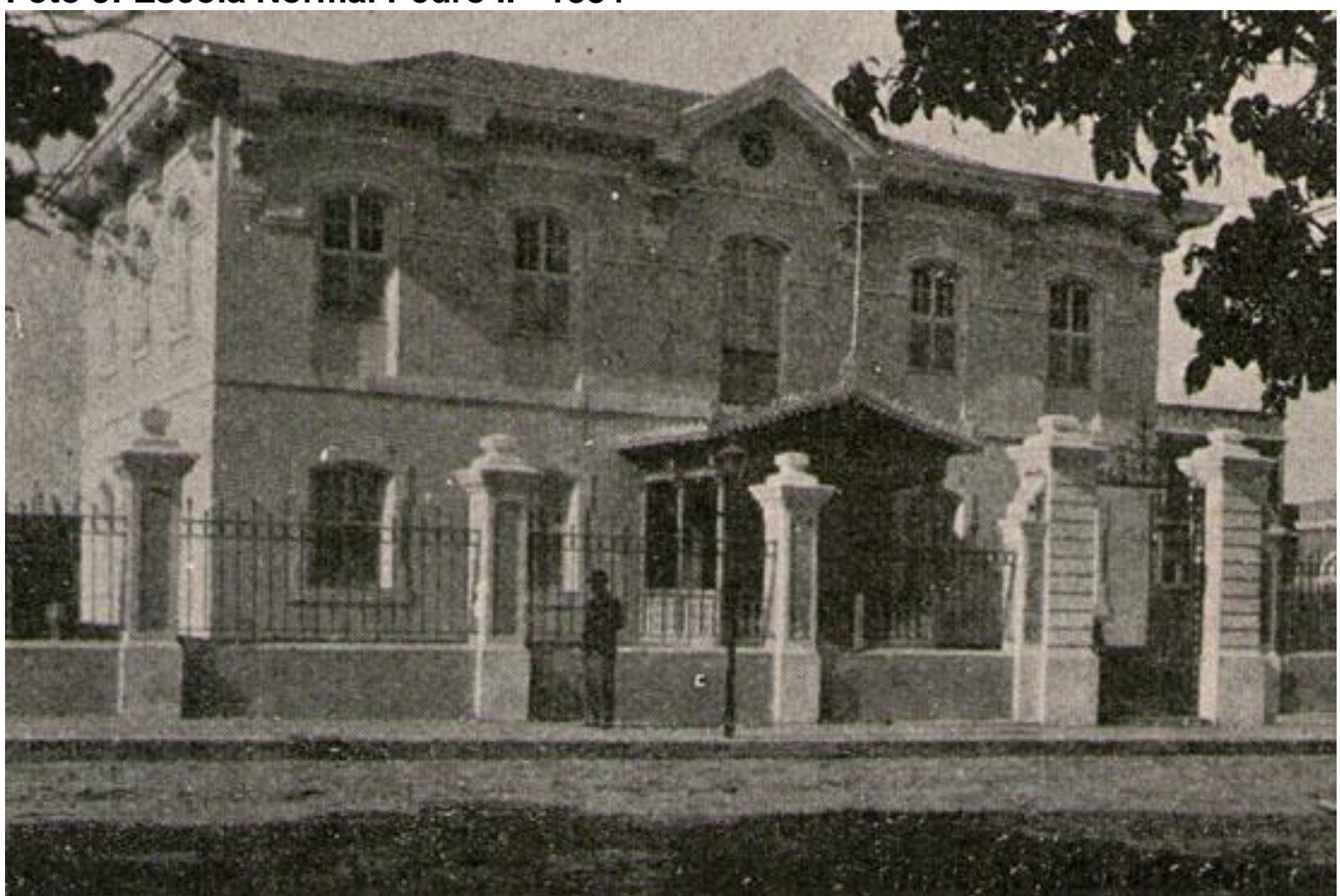

Fonte: $\quad$ http://www.fortalezaemfotos.com.br/2015/07/a-fortaleza-do-tempo-danormalista-12.html. Cedida por Marciano Lopes, anterior a 1910.

Vale ressaltar que o ensino normal é enfocado nos estudos de Castelo (1970), a partir de relatos que o enquadra como um empreendimento de elevados custos para uma Província pobre como era o Ceará. Assim, "criada em 1878, pela Lei $n^{\circ}$ 1790, a Escola Normal somente seria instalada em 22 de março 1884" (GIRÃO, 1956, p. 389).

Sobre os primeiros anos da Escola Normal Vieira; Farias (2002, p. 140) cita Nogueira que resume da seguinte maneira:

A situação da educação pública, sobretudo do magistério primário, era lastimável. A professora, salvo raras exceções, saía da Escola Normal não graças ao seu saber ou ao seu bom desempenho, mas fabricada pelo protetorado político [...] um dos grandes males que nos legou o governo Nogueira Acioly. Formavam-se professores semi-analfabetos, sem preparo efetivo.

O papel dessas professoras era simplesmente presenciar, durante duas horas, os meninos na sala de aula, ou permitir que eles "fossem lá fora" para suas necessidades fisiológicas. Permanecia assentada a mesa, enquanto os alunos estudavam a carta de $A B C$, a tabuada e a cartilha nacional. 
Pode-se constatar que o Ceará apresenta, em sua constituição, problemas diversos. Exploração, concentração de riqueza, privilégios, pobreza, descaso, exclusão, são alguns adjetivos que podem expressar os diferentes modos de uso do território.

\begin{abstract}
As classes dirigentes tinham escolas para a fabricação das elites que governariam um povo amorfo, com sistema de trabalho escravocrata. As forças sociais eram no cenário político representadas por uma minoria letrada e os burgueses e doutores - escreveu Gilberto Freire - iam tomar, nesse período o lugar dos senhores rurais e dos capitães-mores. Mas o aparelhamento do educacional rudimentar era suficiente para pôr-se a serviço desses interesses minoritários, preparando esses sabedores de gramática e de latim de uma sociedade patriarcalista e escravocrata, sem contatos e meios de transporte, vagarosa e tranquila, onde ia iniciar o florescimento das cidades com 0 desenvolvimento comercial $e$ industrial, hierarquizando valores sociais novos, os do segundo Reinado, para representarem no palco parlamentar o jogo dos interesses das suas classes. (MENEZES, 1966, p. 357).
\end{abstract}

Como consequência das formas de uso do território, os graves problemas sociais cresciam, como a fome, a exclusão, a falta de ocupação e a violência. Problemas combatidos, em parte, na forma de distribuição de alimentos, esmolas ou ocupação em obras públicas; e em casos de crimes, com a prisão. "O Governo passava então a ser cobrado. As atribuições paternalistas que antes eram dadas aos grandes proprietários começavam a ser transferidas ao Estado" (CASTRO, 2008, p. 5).

\title{
Meio-técnico-científico, desenvolvimentismo e formação profissional
}

O século XX chega e, com ele, "o progresso técnico-científico dos meios de transportes e de comunicação promove o chamado 'desenvolvimento cearense', contribuindo para a exploração de outras riquezas: oiticica, carnaúba, mamona, café, caju, minérios" (ALMEIDA, 2012, p. 9).

Os investimentos ocorreriam nos setores industriais e de construção. Porém, isso não se daria em todo território cearense, pois os novos objetos se concentravam, cada vez mais, nas áreas mais densas e economicamente viáveis para se investir, - mais precisamente Fortaleza (capital), Baturité, Sobral, 
Maranguape, dentre outras - e traziam mudanças significativas na paisagem e nos costumes.

Além disso, estava nas mãos de poucos, o que desencadeava pobreza e concentração de renda. Assim, o que se pretendia com a implantação da indústria não ocorreu.

Sobre essa questão, Lewis Mumford apud Ortega y Gasset (1963, pp XXIX$X X X)$ ressalta que, " a máquina apareceu em nossa civilização não para salvar o homem da servidão ou de formas ignóbeis de trabalho, mas para adaptar, no possível, a servidão a standards ignóbeis de consumo, formados entre as aristocracias militares".

Nesse período, a formação profissional é uma realidade, vindo a surgir várias instituições que são decorrentes das refuncionalizações dos territórios. O espaço cearense redefine-se de modo significativo. As políticas territoriais voltam-se ao modelo racional e tecnificador, e o espaço, como instância, vai moldando-se a partir das ações e do surgimento de novos objetos, em meio às exigências da atração de investimentos nacionais e internacionais, sobretudo os privados, impondo ao território, uma lógica de organização que busca atender essa nova configuração.

Cabe ressaltar que o modelo de Ensino Profissional adotado, pouco se diferenciava das escolas de ofício. Apesar da substituição do sistema político, acompanhado pelo discurso de mudanças e inovações, o modelo continuou tendo a mesma finalidade. Porém, o ensino de ofícios visou apenas à preparação para o trabalho braçal; o ensino literário era direcionado à elite, e o ensino profissional destinava-se ao preparo do trabalhador manual (CUNHA, 2000).

Karl Marx (1978) apresenta esse dado no contexto da organização do sistema capitalista. Seus escritos falam sobre a relação entre explorados e exploradores. Ele afirma que o processo de produção não é apenas o seu processo de reprodução, mas seu processo de produção como capital, que ocorre por meio do trabalho produtivo, para obtenção do lucro (MARX, 1978).

O autor ressalta, em sua obra O Capital I, no capítulo IV inédito, que o capital não produz apenas capital, mas produz e reproduz massa operária crescente e mostra como essa reprodução envolve a reprodução das classes sociais dando continuidade ao sistema de produção capitalista.

Nessa perspectiva, a reprodução da classe trabalhadora perpassa vários âmbitos sociais, desde a família até as instituições formadoras de cultura, como a 
escola. Esta opera como instância formativa e atua diretamente na produção das qualificações necessárias para o exercício do trabalho.

Nesse contexto, atendendo as demandas do capital, bem como dos usos do território, muitas instituições de formação profissional se fizeram presentes em maior escala na capital, onde a densidade técnica era maior. Cabe mencionar: a Escola Fênix Caixeiral, criada em 1891, voltava-se para o aperfeiçoamento profissional dos caixeiros; a Escola de Comércio do Ceará, criada ainda no Império, extinta e recriada em 1913, quando de fato foi instalada (VIEIRA; FARIAS, 2002); o Colégio São Francisco de Canindé, voltado ao preparo dos jovens para as atividades profissionais, ministrando um curso primário e outro médio e profissional (ALVES, 1966, p. 363); Escolas de Aprendizes e Artífices, criada em 1909 e inaugurada em 1910 (VIEIRA; FARIAS, 2002).

$\mathrm{Na}$ escala federal, a política de Ensino de Formação Profissional foi lançada inicialmente pelo Decreto presidencial № 7.566 (Nilo Peçanha, 1909-1910), para criar "em cada uma das capitaes dos Estados da Republica o Governo Federal manterá, por intermedio do Ministerio da Agricultura, Industria e Commercio, uma Escola de Aprendizes Artifices, destinada ao ensino profissional primario gratuito" (Art. 1․ DECRETO № 7.566, DE 23 DE SETEMBRO DE 1909).

A década de 1930 é considerada por autores que debatem a história da educação, um importante momento no Brasil. A formação profissional, nas modalidades ensino médio e técnico superior, assumiu historicamente importância, quando o Brasil se constitui como uma sociedade urbano-industrial, com forte apoio estatal (WINCKLER; SANTAGADA, 2012).

No final do século XIX, no contexto de uma sociedade agrária oligárquica, já com um processo presente de urbanização, a formação para o trabalho possuía um caráter de controle das classes populares; o que veio a ser substituído pelo projeto industrializante em curso. Desta forma, "abandonou-se a visão de uma educação profissional voltada aos desvalidos". (WINCKLER; SANTAGADA, 2012, p. 98).

É um período marcado por ideias e debates que direcionam o sistema educacional brasileiro, e que tem fortes repercussões na sua condução, e na elaboração do pensamento pedagógico que mobiliza o debate da educação, que resulta no Manifesto dos Pioneiros da Educação Nova (1932), documento escrito por intelectuais brasileiros que teve uma forte repercussão nacional e que se 
contrapunha à centralização e ao autoritarismo que, até então, caracterizavam o campo educacional brasileiro.

No Ceará, nesse período, tem-se como exemplo, os movimentos ligados a partidos operários ${ }^{25}$, as discussões que faziam em contraposição à força da igreja e de alguns políticos nas decisões de cunho coletivo, e os movimentos sociais independentes, de resistência ao poder centralizador e oligárquico ${ }^{26}$

"Entre 1930 e 1945, cresceu a demanda por operários qualificados e quadros técnicos, dada a implantação do capitalismo industrial nacional" (WINCKLER; SANTAGADA, 2012, p. 98).

Em 1942, criou-se o Serviço Nacional de Aprendizagem (Senai) ${ }^{27}$ e foi promulgada a Lei Orgânica do Ensino Industrial, que organiza esse tipo de ensino, não mais exclusivo de empresas e sindicatos, além de equipará-lo ao ensino médio propedêutico. A Lei de Diretrizes e Bases, de 1961, incorporou medidas já em curso nos anos anteriores (WINCKLER; SANTAGADA, 2012, p. 98).

Desse período, resultam as constituições de 1934 e 1937, em que as discussões se aglutinam e as competências e responsabilidades da educação são traçadas.

Na Constituição da República dos Estados Unidos do Brasil, de 1934, a educação passa por algumas alterações e promove avanços significativos no que se refere à aplicação do orçamento da União e municípios (obrigados a aplicar pelo menos $10 \%$ de seu orçamento), estados e Distrito Federal (deveriam investir no mínimo 20\%) (Constituição da República dos Estados Unidos do Brasil de 1934, Art 156).

${ }^{25}$ Esse assunto é abordado na Tese de Adelaide Pereira intitulada (2001) "A imprensa dos trabalhadores no Ceará, de 1862 a 1920". Disponível em: https://repositorio.ufsc.br/xmlui/handle/123456789/82022?show=full Acesso em: 27 de janeiro de 2016.

${ }^{26}$ Ver: $O$ Cangaço (movimento definido por ações, defensivas, político e independentes que se caracterizado por resistências aos modos de uso do território, que era centralizador e excludente), $O$ Caldeirão (foi uma comunidade messiânica, coletiva e igualitária, surgida no Cariri cearense e que tinha como líder José Lourenço, essa foi destruída em 1937 pelo governo Menezes Pimentel com o apoio da Igreja e latifundiários).

${ }^{27}$ Essa organização foi o ponto inicial, que, nos anos subsequentes, veio a ser chamado sistema $S$ (Senac, Senai, Sesc, Sesi e Sebrae), financiado por contribuição legal das empresas e que tem como objetivo a capacitação profissional de jovens e o aperfeiçoamento de trabalhadores (WINCKLER; SANTAGADA, 2012, p. 98). 
Também houve a preocupação com a universalização do ensino primário integral gratuito e de frequência obrigatória extensivo aos adultos, a fim de o tornar mais acessível (Constituição de 1934, lei federal, nos termos dos arts. 5ํㅡ, n. XIV, e 39, n. 8, letras $a$ e b); este, fruto de lutas por investimentos na educação pública e gratuita.

Por outro lado, ainda se fazia presente uma classe com orientação tradicional, própria da estruturação sociopolítica da Velha República, que pressionava para à adoção de medidas que promovessem o desenvolvimento da indústria nacional.

Sob a mesma perspectiva cabe aqui referir à constituição de 1937, que traçou as diretrizes do ensino e a competência da União no campo da educação, e estabeleceu a obrigatoriedade da organização de escolas profissionais pelas empresas e sindicatos.

Lê-se no Art 15 - IX da Constituição dos Estados Unidos do Brasil (de 10 de novembro de 1937):

"Compete privativamente à União: fixar as bases e determinar os quadros da educação nacional, traçando as diretrizes a que deve obedecer à formação física, intelectual e moral da infância e da juventude".

Em seu Art. 129 declara:

A infância e à juventude, a que faltarem os recursos necessários à
educação em instituições particulares, é dever da Nação, dos
Estados e dos Municípios assegurar, pela fundação de instituições
públicas de ensino em todos os seus graus, a possibilidade de
receber uma educação adequada às suas faculdades, aptidões e
tendências vocacionais (BRASIL, 1937, p. 1).

Sobre o ensino técnico profissional:

O ensino pré-vocacional profissional destinado às classes menos favorecidas é em matéria de educação o primeiro dever de Estado. Cumpre-Ihe dar execução a esse dever, fundando institutos de ensino profissional e subsidiando os de iniciativa dos Estados, dos Municípios e dos indivíduos ou associações particulares e profissionais.

É dever das indústrias e dos sindicatos econômicos criar, na esfera da sua especialidade, escolas de aprendizes, destinadas aos filhos de seus operários ou de seus associados. A lei regulará o cumprimento desse dever e os poderes que caberão ao Estado, 
sobre essas escolas, bem como os auxílios, facilidades e subsídios a Ihes serem concedidos pelo Poder Público (BRASIL, 1937, p. 1).

Nesse aspecto, houve iniciativas do governo federal, de maneira a tornar esse artigo efetivo, como a proposta de financiamento privado para o ensino profissionalizante público por meio de apoio econômico dos industriais.

\section{“Modernização" e demandas técnicas}

As demandas cresciam no território e requeriam conhecimentos e aperfeiçoamentos técnicos. As discussões e ações políticas se encaminhavam para atender a esses setores da sociedade.

A rede urbana cearense ganhava corpo; pequenas indústrias despontavam no território ${ }^{28}$, todavia, a cultura rural ainda tinha forte impacto na economia. O que acarretou o fortalecimento do ruralismo, que se contrapunha ao industrialismo e ao urbanismo", originário do domínio coronelista, sustentava-se em ideias que se contrapunham à vida rural e citadina, sendo que a primeira exaltava as vantagens "naturais" e a segunda, destruía da solidariedade "natural" do homem (ARAÚJO, 2011, p.238).

O inquérito agrícola de 1920 registra, para três Estados Nordestinos, 40.279 estabelecimentos rurais. Em 1950, registrava a existência de 86.690, cobrindo uma área de 10.2000.877ha. Em todo o Nordeste, o único Estado que excedia o Ceará em número de estabelecimentos era Pernambuco, porém com área total bem inferior. (POMPEU SOBRINHO, 1966).

Esses fatores, bem como o crescimento econômico nacional, que exigiam novas técnicas nos diferentes setores industriais, comerciais e agrícolas, foram fundamentais para a criação instituições de ensino profissional para dar conta das novas demandas do capital.

A Escola Normal Rural de Juazeiro do Norte se constituiu no âmbito desses anseios. O Ceará atravessa "um período de atividade ruralista intenso" (ALVES,

\footnotetext{
${ }^{28}$ Indústrias de doces que tinham como matéria-prima o caju, goiaba, banana, da castanha do caju para extração do óleo, de cajuína (suco esterilizado do caju), de manteiga de garrafa e posteriormente de manteiga crua.
} 
apud VIEIRA; FARIAS, 2002, p. 191), vinculado à existência dos latifúndios, pelas políticas públicas de "combate à seca", pelas relações de apadrinhamento geradas pelo modelo oligárquico, pelas práticas religiosas presentes e marcantes na região do Cariri.

A ideia de criar uma escola normal rural teve como princípio educar o homem do campo, tendo surgido como uma experiência pedagógica considerada avançada, pois visava à formação do magistério especializado de modo a orientar sua fixação ao meio (Decreto Lei oㅜ 1281, em 10 de Janeiro de 1934).

As ações e discursos favoráveis à constituição de uma escola voltada para a formação de professores ruralistas no Ceará tinham como missão, combater indiretamente o urbanismo e criar nas mentes das novas gerações a consciência ruralista de amor a terra. Porém, essa escola "mais atendeu aos interesses econômicos dos seus fundadores do que ao objetivo educativo a que se propunha", pois seu intuito era fortalecer o poder nas mãos dos senhores donos de grandes terras (ALVES, apud VIEIRA; FARIAS, 2002, p. 191).

A partir da segunda metade do século $X X$, a política de industrialização, proveniente do planejamento e das ações do Governo Federal visando fortalecer a atividade transformadora, volta-se para o financiamento de projetos para 0 desenvolvimento industrial (particularmente nas áreas de infraestrutura e energia), bem como a aplicação de recursos públicos para a formação do trabalhador para as novas demandas territoriais (LIMA, 2011).

O Plano de Metas do Governo Kubitschek (1956-61) evidencia as ações do Estado no processo de modernização e marca a passagem definitiva do País à condição de industrializado e urbano (WINCKLER; SANTAGADA, 2012, p. 99).

Data desse período, a expansão da educação profissionalizante, com o surgimento de ginásios industriais, de centros de educação técnica e de programas de preparação de mão de obra industrial.

Os investimentos priorizavam a formação de técnicos, tendo em vista as metas de desenvolvimento. Em 1959, as instituições federais de ensino profissional passaram à condição de autarquias, com autonomia de gestão e de didática. Nesse período, tenderam a se acentuar as tendências tecnicistas de educação. (WINCKLER; SANTAGADA, 2012, p. 99).

A ideia de modernizar para acelerar o desenvolvimento e progresso do Brasil incentivava novos projetos sociais e culturais, para solucionar problemas cruciais à 
inserção do Estado brasileiro no âmbito dos países mais desenvolvidos economicamente no mundo.

$O$ incremento da indústria, no início do século $X X$, possibilitou um estreitamento das relações entre agricultura e indústria. $O$ uso de máquinas interligou os setores industrial e agrícola, criando uma relação de dependência entre setor primário, industrial e financeiro.

O alargamento industrial propiciou o crescimento das cidades, soma-se a isso, o dinamismo da economia e da sociedade com a implantação de novos objetos, como as rodovias e ferrovias, que proporcionam novas ações e que se faziam evoluir em conjunto com outros elementos do contexto global, propiciando a entrada do Brasil em sua fase de modernização econômica.

Assim, novas geografias se desenharam, "sobretudo, a partir da utilização de prolongamentos não apenas do corpo do homem, mas do próprio território, constituindo verdadeiras próteses" (SANTOS, 2008, p. 31).

Como nessa dinâmica, os elementos que a compõem não evoluem isoladamente, a mesma se estende a outros territórios até atingir o espaço global. Tem-se "um período demarcado por intenso avanço tecnológico, com novas técnicas de produção na transformação de matéria-prima, em outras partes do mundo" (LIMA, 2011, p. 62).

O Ceará, no intuito de acompanhar e se enquadrar nessa política de incentivos, criou o Distrito Industrial, com a finalidade de apoiar investidores do Sul do país e incentivar o processo de "modernização"29 que se alastrava por todo território brasileiro (LIMA, 2011).

Neste sentido, explica-se a preocupação em instalar escolas que pudessem suprir tais necessidades, bem como refuncionalizá-las no sentido de acompanhar as novas demandas, que eram criadas no território consolidando o compromisso com o desenvolvimento industrial. É o caso da Escola de Aprendizes Artifices que é

\footnotetext{
${ }^{29}$ Brum (2006, p. 18) in Trennepohl, (2001, p. 27) define a modernização como processo que consiste, sobretudo, na adoção de padrões de consumo, de comportamento, de instituições, equipamentos e tecnologia, valores e ideias característicos de sociedades mais avançadas, sem importar necessariamente em transformações na estrutura econômica e social. Portanto, um processo de modernização pode ser compatível com uma situação de dependência. Geralmente quem pode importar mais são as regiões e as camadas sociais mais ricas, que têm mais poder aquisitivo. "Daí, uma das consequências seria a consolidação e permanência de uma sociedade dual, dicotomizada: regiões e classes ricas e regiões e classes pobres, com os decorrentes conflitos e tensões" (Brum, 2006, p. 18).
} 
transformada em Liceu Industrial de Fortaleza e, mais tarde, por despacho do Ministro da Educação e Saúde Gustavo Capanema, datado de 28 de agosto de 1941, estabelece para a instituição a denominação de Liceu Industrial do Ceará. Em 1942, pelo decreto 4.12, de 25 de fevereiro de 1942, recebe o nome de Escola Industrial de Fortaleza, e passa a oferecer formação profissional voltada especificamente para a indústria. No ano de 1959, mediante a Lei Federal ํㅜ 3.552 de 16 de fevereiro, no governo de Juscelino Kubitscheck, a escola Industrial torna-se Autarquia Federal, e passa a ter autonomia administrativa, patrimonial e financeira, incorporando a formação técnica de nível médio (NOBRE, 2011; CEARÁ, 2015).

A Constituição de 1946 reafirma a cooperação entre os setores públicos e da indústria, obrigando as empresas agrícolas, comerciais e industriais a ministrarem a aprendizagem de seus trabalhadores menores, bem como manter ensino primário e gratuito para os servidores e seus filhos, nas empresas em que trabalhassem mais de cem pessoas (Constituição dos Estados Unidos do Brasil, 1946, Art. 168. III - IV).

A escola, nesse sentido, se ajusta às atividades que surgem no território, pois seu dinamismo vincula-se à totalidade mundial, diretamente ligado aos movimentos da política, da economia, da cultura e dos processos relacionados aos usos do território de um país. No entanto, sua efetivação vai depender das políticas locais, que também determinam sua implantação e funcionalidade.

No Ceará, a Escola Industrial fazia parte do projeto de modernização do Estado. A construção da Usina de Paulo Afonso foi decisiva para alavancar as reformas que favoreceram a indústria.

A partir daí, foram abertas rodovias com a integração viária de Fortaleza a todas as regiões do País pelas rodovias federais BRs 116 e 222. Cria-se o 1ำ Distrito Industrial (Maracanaú), e mediante os incentivos da SUDENE, os financiamentos do Banco do Nordeste e os incentivos estaduais, novas empresas se instalam, tanto as provenientes de outras regiões como locais. "O grande impulso industrial, no entanto, vai ocorrer a partir de 1969, quando a participação do setor secundário do PIB cearense, segundo o IPEADATA (2006) passa de 9,72\% em 1969 para 21,01\% em 1975" (LIMA, 2008, p. 176).

Ainda no contexto da modernização e "dentro do projeto de tornar o Ceará o $3^{\circ}$ pólo industrial do Nordeste, cria-se o Fundo Monetário Industrial (FDI), para atrair capitais de outras regiões" (LIMA, 2008, p. 176). 
A modernização territorial em curso foi provocada principalmente por interesses de caráter econômico, a qual necessita para a sua realização dos macrossistemas técnicos. Estes, por sua vez, modernizam-se em virtude dos avanços científicos e tecnológicos, ao mesmo tempo em que concorrem para novas modernizações territoriais, absorvendo as modernizações tecnológicas de cada período histórico.

O território cearense, tendo por base Fortaleza, se torna parte integrante do sistema econômico hierarquizado que se desenvolve no país. A intensificação da competição inter-regional "inibe e destrói atividades regionais mais frágeis e ineficientes, como, a partir de medidas contempladas pela política de desenvolvimento regional, à criação e ao surgimento de novas atividades, através de uma acelerada acumulação de capital" (LIMA, 2008, p. 175).

Nesse contexto, surge o Plano de Metas Governamentais (1ํ PLAMEG 1963/1967) no governo de Virgílio Távora, que tem como meta dar subsídios para o Estado se industrializar e se modernizar.

Carvalho (1988) demarca o período de 1959 a 1964 como a fase de modernização conservadora, momento em que o Estado intervirá com reformas planejadas, organizada por uma instituição nova, a Superintendência do Desenvolvimento do Nordeste - SUDENE, órgão de fomento ao desenvolvimento do nordeste brasileiro.

No Ceará, a implantação de projetos de apoio ao pequeno produtor, implementados pela SUDENE, buscava criar uma infraestrutura produtiva capaz de tornar as estruturas econômicas do semiárido menos vulneráveis às irregularidades das chuvas.

Segundo Pontes (2009, p. 42), "a infraestrutura básica do Nordeste foi implantada nos períodos de secas, contando com as instituições federais, construindo não apenas açudes, mas estradas, campos de pouso, reservatórios d'água, cercas nas propriedades privadas e etc".

De acordo com a Fundação Instituto de Pesquisa e Informação do Ceará IPLANCE (1982) apud Pontes (2002, p 42-43):

a infraestrutura física, como elemento de base para 0 desenvolvimento das relações econômicas, evoluiu rapidamente desde fins do século passado [XIX], progredindo para o nível de 
atividade contínua a partir de 1909, com a criação da Inspetoria de Obras Contra as Secas (IOCS atual DNOCS) [...]. (1982, p.58).

Contudo, o quadro político não se diferenciava do século passado, a concentração de terras e renda, o problema da seca e a falta de investimentos, ainda atingia uma maioria pobre, analfabeta, sem terras e sem perspectivas.

A educação escolar se concentrava na capital e nos locais onde a economia era vultosa, assim, esta continuava sendo um privilégio dos mais abastados. A fome e a pobreza constituiam um problema emergencial, mas ainda não solucionado. Neste aspecto, os investimentos se voltavam principalmente para amenizar a miséria, o que se fazia por meio da distribuição de alimentos e de trabalhos em obras do governo ${ }^{30}$, até então, a educação continuava em segundo plano.

No contexto econômico, o setor têxtil apresentava um quadro de retrocesso, "descapitalizado, tecnicamente obsoleto e enfrentando recorrentes estiagens (195153; 1958), assistiu apático ao crescimento e modernização do parque têxtil do Centro-Sul" (ARAGÃO, 1989 apud ALMEIDA, 2012, p. 11).

De acordo com Almeida (2012, p. 11), "a retração também se estendeu aos setores tradicionais (alimentícia, bebidas, têxtil) que representam a maioria dos estabelecimentos instalados". Com isso, "uma mão-de-obra de cerca de $10 \mathrm{mil}$ trabalhadores foi dispensada no segmento de produtos alimentares, representando $76,46 \%$ da força de trabalho anteriormente ocupada" (COIMBRA, 1998 apud ALMEIDA, 2012, p. 11), e ficou desempregada, afetando o mercado interno e provocando movimentos migratórios em direção aos grandes centros metropolitanos (ALMEIDA, 2012).

A partir dos anos 1960, a intervenção dos organismos de fomento, como a SUDENE, alteram intensamente a infraestrutura e o quadro produtivo do Ceará, o que ocasionou o desenvolvimento industrial, transformando a capital cearense num pólo têxtil e de confecções (ALMEIDA, 2012).

"A política de industrialização, definida pela SUDENE, teve por base o estímulo à iniciativa privada, através dos incentivos fiscais e financeiros concedidos pelo governo federal a empreendimentos que viessem se instalar na área" (BAIMA, 1989, p. 121).

\footnotetext{
${ }^{30}$ Sobre esse assunto cabe referir os estudos de Frederico Castro Neves (2002) sobre a seca no Ceará.
} 
Segundo Almeida (2012, p. 11), a ação da SUDENE era baseada num fundamentalismo industrial, onde "havia e ainda perdura na região de que a atividade industrial redimiria o Nordeste de seus problemas" [...] "inclusive sua atualidade no discurso político moderno, agora mais pretensamente ligado à geração de emprego e renda".

No campo educacional é dado incentivo à iniciativa particular mediante amparo técnico e financeiro dos Poderes Públicos, inclusive bolsas de estudo; respeitadas as disposições legais, previstas na lei (Constituição da república federativa do Brasil 24/01/1967, Art. 168 - § 2º).

Também permanece a obrigatoriedade das empresas comerciais, industriais e agrícolas de manter, pela forma que a lei estabelecer, o ensino primário gratuito de seus empregados e dos filhos destes. Elas são ainda obrigadas a ministrar, em cooperação, aprendizagem aos seus trabalhadores menores (Constituição da república federativa do Brasil, 24/01/1967, Art. 170).

Segundo Araújo (1997, p. 12), foi "o setor público quem puxou o crescimento das atividades econômicas que mais se expandiram na região nos anos 70 e 80 ".

Segundo dados da Sudene (1992), atividades como bens imóveis e serviços às empresas; atividades financeiras; produção de energia elétrica e abastecimento de água; serviços comunitários sociais e pessoais, destacaram-se como atividades muito dinâmicas e, na maioria delas, o investimento público foi fundamental (ARAÙJO, 1997, p. 12).

As ações implementadas pela ideologia desenvolvimentista do Estado, ligadas a atividades de cunho empresarial, fortaleceu grupos econômicos locais mais ou menos integrados à economia nacional. Os setores ligados à indústria e comércio cresceram exponencialmente, aumentado às demandas que, cada vez mais, requeriam mão-de-obra qualificada para atendê-las.

As diversas ações e determinações para o território cearense, privilegiavam em grande parte setores econômicos privados e seus projetos de empreendedorismos, que se encaminhavam para uma política de industrialização que se concentraram em Fortaleza, Juazeiro do Norte, Crato e Sobral.

De certo, os investimentos públicos e privados tiveram como consequência a oferta de diferentes manifestações de educação, ampliando as diferenças entre acesso, permanência e oportunidades. Dentre elas, o ensino técnico profissional que 
se encaminhava para a consolidação, na tentativa de atender às novas demandas territoriais.

Nesse aspecto, as reformas de Capanema ${ }^{31}$ e o decreto no 1.238/1939 32 são exemplos dos esforços empregados para implementação, financiamento e supervisão de uma política concreta de formação profissional brasileira. Pois, no contexto do Estado Novo, havia a defesa do desenvolvimento industrial e a preocupação com a preparação profissional para jovens trabalhadores da indústria; o que justificava a política de ensino profissionalizante.

Desse modo, "a vertente profissionalizante, parte final do ensino secundário, era constituída pelos cursos normal, industrial técnico, comercial técnico e agrotécnico. Todos com o mesmo nível e duração do colegial, entretanto não habilitavam para o ingresso no ensino superior" (MINISTÉRIO DA EDUCAÇÃO SECRETARIA DE EDUCAÇÃO PROFISSIONAL E TECNOLÓGICA, 2007, p. 12).

Cabe ressaltar que um aspecto fundamental que tem sido destacado nas avaliações feitas sobre a política de industrialização, proposta e colocada em prática pela SUDENE no Nordeste, aponta que uma das metas preconizadas pela SUDENE, ou seja, a criação de emprego mediante a instalação de indústrias, não ocorreu nas proporções esperadas, "pois estas optaram pelo uso de uma tecnologia avançada e, portanto, poupadora de mão-de-obra, o que era de se esperar, dado o caráter de economia capitalista que visa acima de tudo maximizar os lucros" (BAIMA, 1989, p. 123).

A década de 1960 é marcada pela intensificação da competição interregional no mercado nordestino, que inibe e modifica atividades mais frágeis e ineficientes, bem como por ações políticas de desenvolvimento regional que possibilitaram a criação e o surgimento de novas atividades, através de uma acelerada acumulação de capital. (GUIMARÃES NETO apud LIMA, 2008).

Nos setor educacional, instituem-se propostas para a reformulação do ensino técnico. Deste modo, o currículo dos então chamados cursos de 20 grau,

\footnotetext{
${ }^{31}$ As reformas engendradas sob a gestão de Gustavo Capanema tiveram forte repercussão no encaminhamento do ensino durante o estado Novo, sob sua vigência é que são acionados decretosleis referentes ao ensino industrial (Decreto-lei o 4.073/ 1942), secundário (Decreto-lei no 4.244/1942) e comercial (Decreto-lei 6.141/1943). Também nesse período é criado o Serviço nacional de Aprendizagem Industrial - SENAI (Decreto-lei 4.048/1942) (VIEIRA; FARIAS, 2002, p. 179).

${ }^{32} \mathrm{O}$ decreto forçava empresas com quinhentos ou mais empregados a financiar o treinamento profissional dentro de suas indústrias.
} 
ficou composto por um núcleo comum, obrigatório em âmbito nacional, e por uma parte diversificada, com o mínimo a ser exigido em cada habilitação profissional ou conjunto de habilitações afins, que poderiam ser realizadas em regime de cooperação com as empresas (Lei 5692 DE 11 DE AGOSTO DE 1971).

Essa reforma educacional foi discutida posteriormente ao golpe de 1964, quando os grupos mais liberais tomaram o poder e criaram meios para ampliar vários setores econômicos, tais como, indústria, transportes, comunicação, mineradoras, indústria energética, de construção naval, de financiamento público e de incentivos fiscais.

Nesse aspecto, criam-se Metas de Bases para Ação do Governo, 1970/1971 e o I Plano Nacional de Desenvolvimento (I PND), lançado em 1971 e desenvolvido entre os anos de 1972 a 1974, o qual pretendia transformar o Brasil em uma "nação desenvolvida" dentro de uma geração.

Acordos internacionais permitiram colocar em prática a ideia de "desenvolvimento", firmada estrategicamente na Conferência de Punta del Este, através da Carta de Punta del Este, onde foram definidas as condições para alcançar tal objetivo ${ }^{33}$.

A educação teria um papel fundamental, treinando mestres, técnicos e especialistas. O que levou a uma articulação com a educação, mediante acordos de cooperação internacional, como os acordos entre o MEC e a AID (Agency for Internacional Development). A direção técnica da educação do país foi coordenada por técnicos americanos que estabelecia várias metas, dentre as quais estavam o aperfeiçoamento do ensino primário, com a expansão quantitativa dos sistemas escolares e com o aumento da sua produtividade.

A reformulação de uma legislação específica para 0 ensino profissionalizante, como forma de ampliar a qualificação de mão-de-obra, também foi definida como meta. As já citadas Leis 4.024/61, 5. 540/68 e 5. 692/7 tiveram influência de princípios que se baseavam em produção e produtividade, em que a educação é vista como mercadoria e com orientações puramente técnicas.

\footnotetext{
${ }^{33}$ A Conferência de Punta del Este aconteceu em Janeiro de 1962; na ocasião, foram firmados acordos de ajuda americana para países signatários, com o intuito de formular planos de desenvolvimento nacionais.
} 
Muitas críticas foram feitas e houve protestos de toda a ordem, mas o país ainda sofria as represálias e a influência do Ato Institucional $n^{0} 5^{34}$.

Contudo, como território de todos, no lugar, abre-se brechas para as resistências e o desejo de reformas. Em meio a isso, o espaço geográfico agrega outras demandas com o surgimento de novos objetos e, com eles, novos modos de pensar e gerir o uso do território.

Os novos usos e as novas demandas econômicas: refuncionalização do ensino para o atendimento ao mercado globalizado.

No contexto educacional, os anos de 1980 marcam a criação da lei 7044/82, que veio substituir o termo qualificação do trabalho por preparação para o trabalho, retorna-se à ênfase na formação geral, propedêutica, e busca-se englobar o homem enquanto cidadão, sem isolá-lo do trabalho.

A citada lei revogou a compulsoriedade profissionalizante do ensino de $2^{\circ}$ grau e a habilitação profissional ficou a critério do estabelecimento de ensino, o que resultou na diminuição de oferta de mais cursos profissionalizantes nos anos que se seguiram, tomando por base as orientações da Lei 7044/82.

Várias escolas, de diferentes sistemas estaduais de ensino, já não ofereciam a preparação para o trabalho no ensino de $2^{\circ}$ grau, e o caráter propedêutico da antiga escola média (instância preparatória para o vestibular) se proliferou, fortalecendo a rede particular de ensino. Isto facilitou também a proliferação de cursinhos pré-vestibulares, que elitizaram mais ainda o acesso às universidades públicas, o que incentivou a privatização do ensino superior.

Os novos usos, portanto, que congregam uma maior integração econômica, em conjunto com a intensificação da articulação comercial, criam e modificam as relações preexistentes no território, fazendo um reajuste para atender às exigências das novas demandas que passaram a existir.

\footnotetext{
${ }^{34}$ O Al-5, baixado em 13 de dezembro de 1968, durante o governo do general Costa e Silva.Vigorou até dezembro de 1978 e produziu um elenco de ações arbitrárias de efeitos duradouros. Definiu o momento mais duro do regime, dando poder de exceção aos governantes para punir arbitrariamente os que fossem inimigos do regime ou como tal considerados.
} 
O Ceará, como parte da totalidade, também buscou o atendimento das demandas econômicas, tendo no comando as oligarquias. O descaso com 0 aumento da pobreza e a falta de recursos para uma grande parcela da população, fazia parte do cenário político, acarretando, ainda hoje, fortes reflexos no estado, sobretudo em relação ao direito a uma educação de qualidade.

Assim, a modernização, que pretendia transformar a região agrícola em industrial, não ocorreu como era esperado, dada a força das oligarquias tradicionais, que queriam manter a concentração de renda e poder político (LIMA; VASCONCELOS; FREITAS, 2011).

Nas últimas décadas do século $X X$, quando o mundo passa por um novo processo de modernização, com infraestruturas baseadas em inovações técnicascientíficas, quando os parâmetros da produção e dos fluxos se baseiam nas criações dos meios de comunicação e de informação, o Estado passa a destinar maiores investimentos em setores ligados à produção industrial, à engenharia de construção, e a serviços, na busca de intensificar os fluxos de capital, de mercadorias e pessoas. (LIMA, 2011).

Em meio às mudanças que se processavam no mercado de trabalho, se organizam ações para a formação de mão-de-obra e qualificação profissional, que até então era desenvolvida de forma fragmentada e desarticulada por diversos institutos de formação profissional, de natureza pública e privada, nos chamados "Sistema S" (CEARÁ, 2006).

Com a regulamentação do Fundo de Amparo ao Trabalhador - $\mathrm{FAT}^{35}$, foram criadas as condições jurídico-institucionais para que o Governo Federal pudesse propor e coordenar programas nacionais, os quais incluíam as políticas públicas de emprego (CEARÁ, 2006).

Sendo assim, os programas de qualificação profissional, nesse âmbito, financiados pelo Fundo, foram implementados em 1993, apesar de sua regulamentação datar de 1990. Incialmente, tais ações foram realizadas em alguns Estados e foram destinadas aos beneficiários do seguro-desemprego (CEARÁ, 2006).

\footnotetext{
${ }^{35}$ O FAT foi criado em 1988 pela nova Constituição Brasileira e regulamentado em 1990 pela lei federal 7.998. Os recursos do FAT são contribuições sociais de setor público e privado incidentes sobre o faturamento das empresas (PIS, PASEP), além de multas sobre encargos devidos, juros e correção monetária de empréstimos (CEARÁ, 2006, p. 26).
} 
Sua ampliação ocorreu com a criação do Plano Nacional de Educação Profissional - PLANFOR ${ }^{36}$, considerado marco importante na constituição histórica da qualificação profissional, uma vez que confere a esta o estatuto de política pública, integrando-a às demais políticas que compõem o sistema público de emprego.

A implementação do PLANFOR ocorreu num contexto fortemente marcado pelas transformações decorrentes do processo de globalização, em que os territórios incorporavam as novas tecnologias e buscavam se adequar às exigências impostas pelo mercado globalizado.

"Esse novo paradigma produtivo, por sua vez, passou a demandar novas habilidades e competências dos trabalhadores, exigindo um perfil profissional compatível às necessidades do novo modelo de produção flexível" (CEARÁ, 2006, p. 27).

Essa nova modernização, - "com inovações técnicas-científicas: quando os parâmetros da produção e dos fluxos se baseiam nas criações dos meios de comunicação e informação" - tem forte impacto no sistema produtivo mundial e faz com que o território incorpore os novos objetos desse processo (LIMA; VASCONCELOS; FREITAS, 2011, p. 63).

Segundo Lima (2011), essa política foi inicialmente vislumbrada pelas classes dominantes, e contaram com o auxílio do Estado, que acatou as novas regulações do capitalismo dominante, e fez-se presente no Ceará, através da implementação de projetos voltados ao turismo, industrialização do interior, serviços modernos, e agricultura destinada à exportação. Nesse quadro, o Governo do Ceará cria a Secretaria do Turismo do Estado do Ceará - SETUR (1995) e a Secretaria de Desenvolvimento Rural - SDR (1997), nomeada mais tarde de SEAGRI (2003)

O Estado passa a fornecer os subsídios necessários para uma melhor adequação ao modelo globalizador, e para intensificar os fluxos de capital, mercadorias e de pessoas (LIMA; VASCONCELOS; FREITAS, 2011).

No campo, as políticas públicas se direcionam aos projetos de irrigação. A criação da SEAGRI direciona as ações do Estado aos interesses do Agronegócio com a criação do Programa Cearense de Agricultura Irrigada - PROCEAGRI, "que

36 "O PLANFOR foi inicialmente denominado de Plano Nacional de Educação Profissional no biênio 1996/1997, a partir de então mudou para Plano nacional de Qualificação do Trabalhador, assim permanecendo até o início do governo Lula (2003), quando foi criado o Plano Nacional de Qualificação - PNQ, em substituição ao PLANFOR" (CEARÁ, 2006, p. 26). 
estabeleceu dois projetos estratégicos: Caminhos de Israel, como apoio à agricultura de sequeiro ${ }^{37}$, e Agropólos $^{38}$ (MAPA 5), com maior expressão de apoio político, financeiro e de infraestrutura" (SABADIA et al apud LIMA; VASCONCELOS; FREITAS, 2011, p. 65).

\footnotetext{
${ }^{37}$ Agricultura de sequeiro é uma técnica agrícola para cultivar terrenos onde a pluviosidade é diminuta.

${ }^{38} \mathrm{O}$ conceito de Agropólos foi definido pela SEAGRI, visando a articulação e a parceria entre empresa-Estado. Consolidado mais tarde como Instituto Agropólos, esse instituto definiu seis áreas territoriais de atuação: Região Metropolitana; Baixo Jaguaribe; Ibiapaba; Baixo Acaraú; Centro-Sul e Cariri. O principal objetivo era viabilizar a atividade empresarial na agricultura baseado em um novo padrão produtivo e de mercado (LIMA; VASCONCELOS; FREITAS, 2011, p. 63).
} 
Mapa 5: ESTADO DO CEARÁ: Polos de Agricultura Irrigada. 2017.

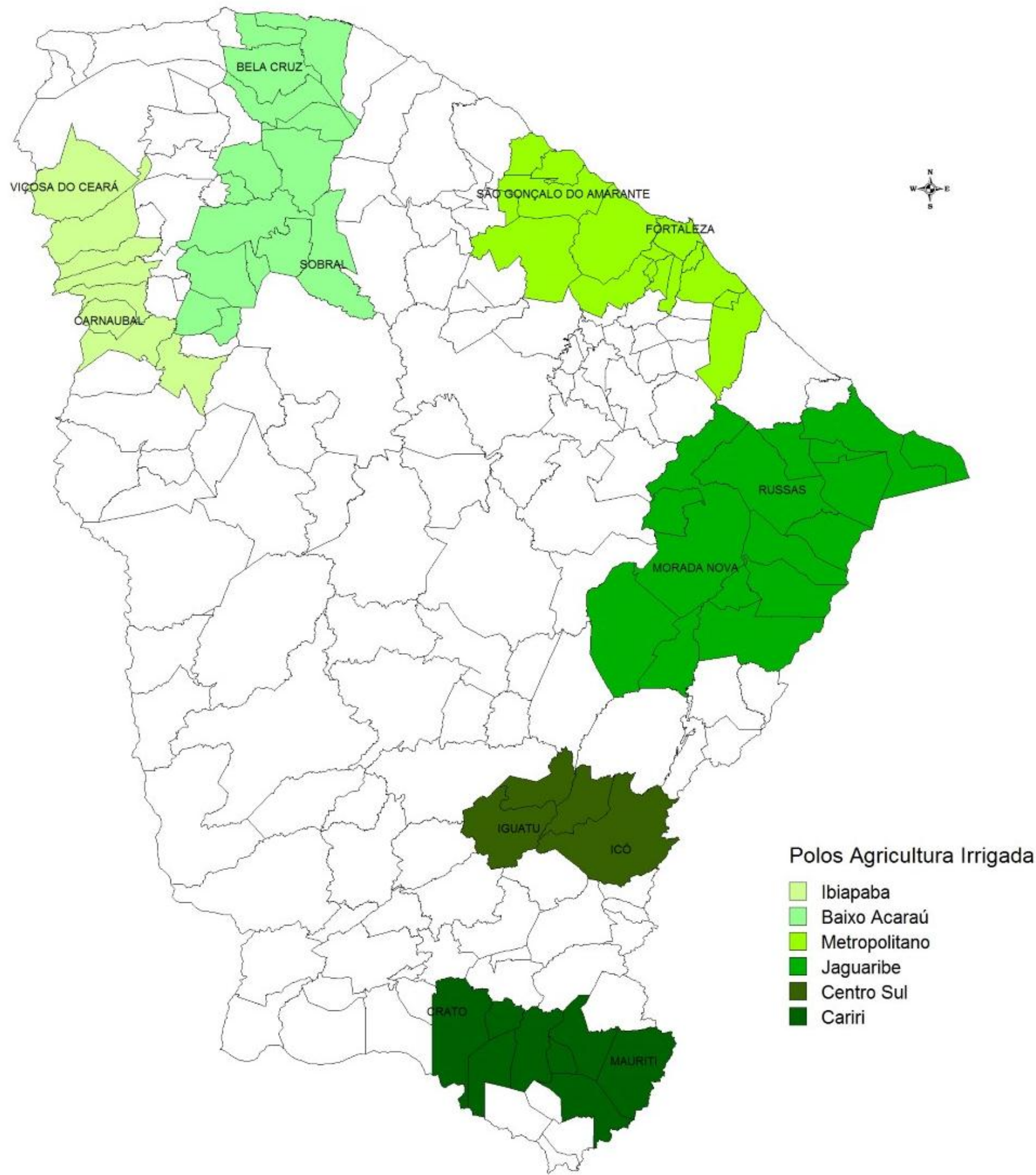

Fonte: Agência de Desenvolvimento do Ceará - Adece/ Governo do Estado.

Elaboração Cartográfica: Markelly Fonseca de Araujo. Software Maplnfo Professional. 
Atualmente o território Cearense é refuncionalizado e normatizado "por políticas territoriais, de cunho modernizante, racional e tecnificador, privilegiando as metamorfoses do espaço para adequá-lo às exigências da atração de investimentos nacionais e internacionais, sobretudo privados" (LIMA; SANTOS, 2012, p. 66).

Segundo Quintiliano (2008) a década de 1990 apresenta-se como um período de implantação em larga escala, de novos objetos e modernas/modernizantes políticas territoriais no Ceará.

Sob essa nova perspectiva, o Ceará refuncionaliza-se de modo significativo, e a educação profissional apresenta novas definições e novos encaminhamentos que se dão em conformidade com a lógica capitalista dos interesses dos atores hegemônicos da economia e da sociedade, incorporados às correntes da globalização, prevalecendo a lógica do mercado e sua adequação, principalmente no quesito educação profissional. 


\section{PARTE II}

\section{GLOBALIZAÇÃO, MEIO-TÉCNICO-CIENTÍFICO- INFORMACIONAL E AS NOVAS DEMANDAS EDUCACIONAIS NO CEARÁ}




\section{Foto 4: Complexo Industrial e Portuário do Pecém}

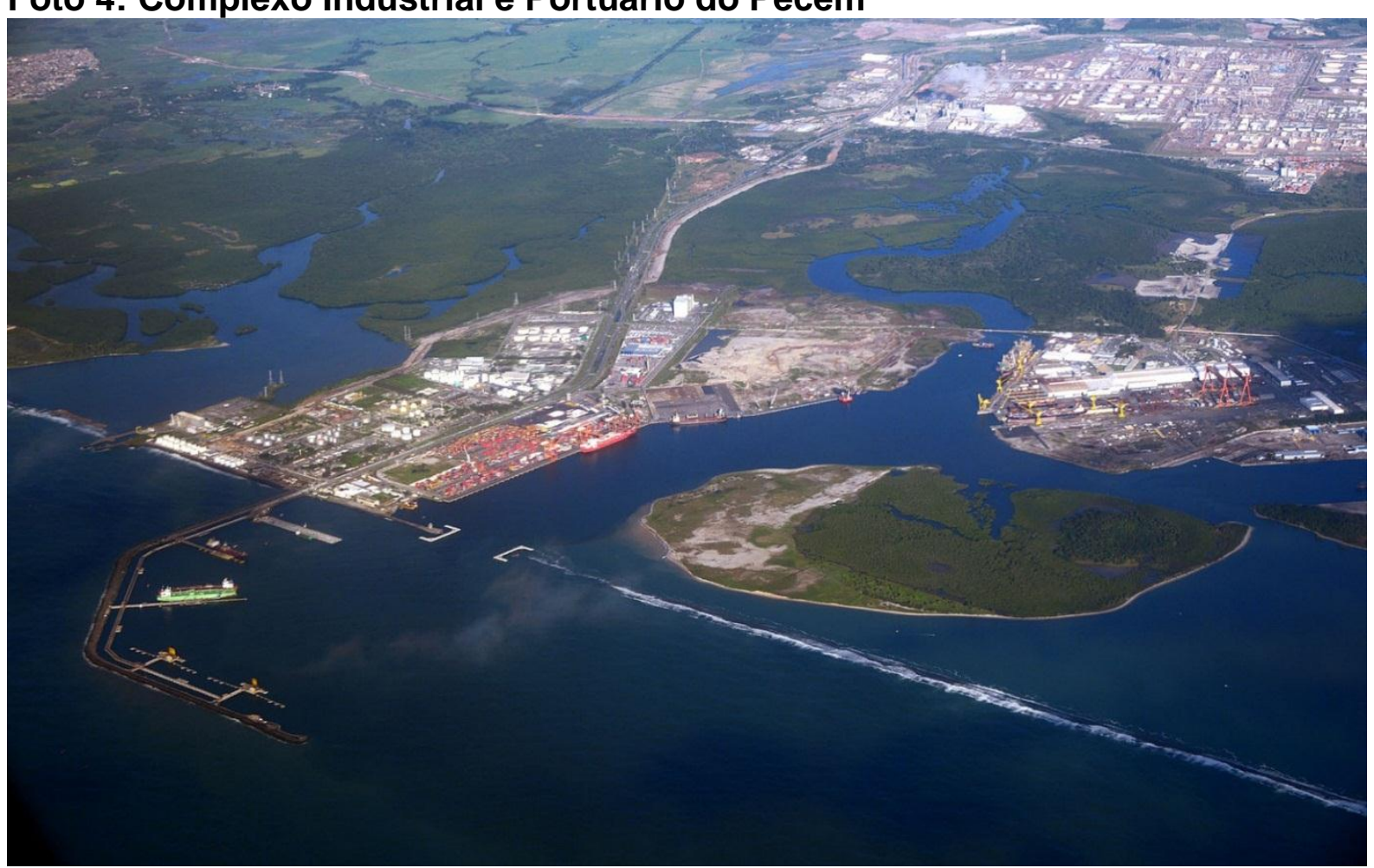

Foto: André Pessoa, 2013.

Fonte: http://www.flickr.com/photos/andrepe...eDRKoNDKF5P/

Nessa parte, serão discutidos os usos do território no sentido de mostrar a incidência das verticalidades, o que determina em grande parte a opção pela educação Técnica, os novos equipamentos e o surgimento das novas demandas.

Busca-se fazer um resgate do que ocorre para gerar as demandas que são criadas e/ou refuncionalizadas. Assim, para responder, questionou-se: Por que o meio técnico se instala? Que fatores são determinantes para a geração das novas demandas? 
CAPÍTULO 3

O MEIO TÉCNICO-CIENTÍFICO-INFORMACIONAL E A EDUCAÇÃO TÉCNICA NO CEARÁ: UMA DUPLA AÇÃO SIMULTÂNEA

Nesse capítulo, discute-se o meio-técnico-científico-informacional e sua constituição a partir dos usos do território cearense. Analisa-se, nesse contexto, as políticas educacionais que são fundamentadas, principalmente, por uma demanda globalizada, tendo por influência as decisões de organismos internacionais na elaboração dessas políticas. Assim, busca-se explicar como as demandas surgem no território, de modo que seu uso atende, em sua maioria, setores ligados à economia mundial, ficando as solidariedades à mercê da própria estrutura local, porém interligadas à totalidade. 


\section{Capítulo 3. O meio técnico-científico-informacional e a educação técnica no} Ceará: uma dupla ação simultânea

O período atual, denominado técnico-científico-informacional, é caracterizado pela profunda interação entre ciência, técnica e informação (SANTOS, 2012).

É aqui denominado a extensão das melhorias técnicas e tecnológicas no território: modernas rodovias, ferrovias, implantação de aeroportos, portos, extensão das redes técnicas de toda ordem, de modo a inserir a cidade e a região nos requisitos prementes da modernidade.

Podemos dizer que esse meio é o território usado pelas técnicas, a serviço especialmente das empresas, - não fora isso as populações não teriam carências em hospitais, escolas e outros equipamentos de interesse e consumo coletivo essas, por meio do uso do território, atribuem ao espaço geográfico novos objetos técnicos, caracterizados por uma carga de racionalidade sistêmica que proporciona sua rápida, extensa e seletiva difusão territorial.

O espaço geográfico, totalidade dinâmica, já que este é instância da sociedade,

reproduz a totalidade social na medida em que essas transformações são determinadas por necessidades sociais, econômicas e políticas. Assim, o espaço reproduz-se, ele mesmo, no interior da totalidade, quando evolui em função do modo de produção e de seus momentos sucessivos. Mas o espaço influencia também a evolução de outras estruturas e, por isso, torna-se um componente fundamental da totalidade social e de seus movimentos (SANTOS, 2008, p.33).

Como parte da totalidade dinâmica, o Brasil, nas duas últimas décadas, agregou-se ao contexto globalizador, com a entrada das inovações técnica-científica informacional, o que incidiu na sua organização socioespacial.

Paralelamente a esse processo, estreitaram-se as relações a nível mundial entre os países e as empresas.

No contexto educacional, consolidava-se a influência de organismos internacionais na elaboração das políticas em diversos lugares do mundo. 
Documentos $^{39}$ elaborados por agências multilaterais multiplicaram-se, principalmente aqueles elaborados pela Comissão Econômica para a América Latina e o Caribe $(C E P A L)^{40}$ e pelo Banco Mundial.

No caso do território cearense, este também se torna um receptor dos novos objetos e das novas ideias, respondendo a uma demanda globalizada alicerçada na ideologia desenvolvimentista de modernização, propagada nos anos de 1960. Este vem sendo incorporado a um sistema técnico de engenharia, projetado e construído de modo integrado, para atender a investimentos que são intencionalmente pensados, para propiciar as ações de certos agentes em determinadas porções do território.

No contexto dessas ações, observa-se que a partir da década de 1990, temse: a implantação de indústrias com incentivo fiscais e reestruturação de estradas e vias para facilitar a circulação das mercadorias, o incentivo à promoção do turismo no Estado, a instalação de infraestruturas voltadas ao agronegócio ${ }^{41}$ e o desenvolvimento de políticas públicas de emprego, através de Planos, Programas e Projetos.

Os programas ${ }^{42}$ correspondem a articulações entre os Governos Federal, Estadual e Municipal, para o planejamento territorial, com políticas de arrecadação

${ }^{39}$ Esses documentos "faziam críticas contundentes ao papel tradicional do Estado na educação
latino-americana e propunham mudanças importantes nessa área". "Os discursos internacionais
repetiam incansavelmente dois bordões: a) a importância da educação básica (no Brasil, reduzida à
escola fundamental) para o novo padrão de desenvolvimento dos países periféricos e b) a
necessidade de o Estado tornar-se menos provedor de financiamento e mais indutor de qualidade,
por meio de diversos mecanismos de controle, tais como avaliações externas do sistema e a
convocação dos pais e da sociedade para participação tanto do financiamento quanto da gestão
escolar" (ZIBAS et al, 2005, p. 5).

${ }^{40}$ Ramon de Oliveira no seu artigo "O legado da CEPAL à educação nos anos 90" discute sobre a influência desta instituição na década de 1990 afirmando a relevância do seu papel no processo das políticas educativas em todo o continente latino - americano e região caribenha. Essa instituição atribuía a educação um dos principais fatores responsáveis pela elevação do patamar de competitividade internacional dos países desta região, capaz de fazer frente às diversas transformações sucedidas na economia ao nível global.

${ }^{41}$ Neste contexto, há estudos realizados por órgãos estaduais (IPECE) com publicações vários de autores, bem como publicações de textos, artigos e dissertações que tratam do assunto. Chamo atenção para os estudos do Professor Luiz Cruz Lima sobre a Reestruturação do Ceará, de seus alunos Tereza Vasconcelos e Aridênio Quintiliano.

${ }^{42}$ Programa de Infraestrutura em Saneamento do Estado do Ceará (SANEAR); Programa de Trens da Região Metropolitana de Fortaleza (METROFOR); Programa de Ação para o Desenvolvimento do Turismo no Nordeste (PRODETUR); Programa Rodoviário do Ceara (CEARA II); Programa de Combate à Pobreza Rural (São José); Programa de Gerenciamento e Integração de Recursos Hídricos (PROGERIRH); Programa de Desenvolvimento Sustentável de Recursos Hídricos para o Semi-Árido Brasileiro (PROAGUA); Programa de Apoio ao Saneamento Integrado Sertão (PROASIS); 
financeira dos cofres da União, Tesouro Estadual, bem como de bancos privados para o desenvolvimento e execução de projetos regionais e estaduais; os quais refuncionalizam as formas-conteúdos territoriais, em grande parte, em favor das forças dominantes, ocasionando privilégios para algumas classes em detrimento de outras, e produzindo desigualdades em relação ao acesso aos bens e serviços ofertados pelo próprio Estado e pela iniciativa privada, que, em sua grande maioria, tem o auxílio deste.

\section{O Ceará no contexto do meio técnico-científico-informacional}

No Ceará, o território vem sendo equipado de infraestrutura, principalmente em relação a fluxos, ou seja, rodovias, ferrovias e área de ciência e tecnologia, para dotar o território de aparato técnico-científico, com profissionais capacitados para os "novos" ramos das atividades produtivas, e com maior participação nos lucros e rendimentos do mercado internacional, para atender, assim, às exigências produtivas e viabilidades técnicas das empresas instaladas, e aquelas que vierem a se instalar.

As demandas surgem no território, de modo que seu uso atende, em sua maioria, a setores ligados à economia mundial, ficando as solidariedades à mercê da própria estrutura local, porém interligadas à totalidade ${ }^{43}$.

As ações que conduzem as políticas territoriais se estabelecem como verticalidades, pouco considerando o espaço banal. Os investimentos são

Programa de Desenvolvimento Urbano e Gestão (PROURB-Hídrico e PROURB-Urbano); Programa Habitacional (HABITAR-BID); Programa de Apoio às Reformas Sociais para o Desenvolvimento de Crianças e Adolescentes (PROARES); Programa Nacional de Agricultura Familiar (PRONAF); e o Projeto Ação Fundiária (QUINTILIANO, 2008).

${ }^{43}$ Ricardo Castilho no texto intitulado "Três dimensões da Solidariedade em Geografia", discute o fenômeno mostrando que o Estado brasileiro tem se endividado para favorecer a instalação de empresas multinacionais, fruto de uma associação entre essas empresas e os poderes locais, que têm conquistado maior autonomia em relação à constituição federal. "Três dimensões da Solidariedade em Geografia”, em Revista Experimental, São Paulo, 1997, ano II, n. 3. 
consideravelmente altos e proporcionaram mudanças estruturais, políticas, econômicas e ideológicas, de modo que os projetos pensados e desenvolvidos, comungam com o constructo do ideal capitalista.

O território usado cearense é incorporado à produção global, propiciado por normas favoráveis aos investimentos, isenções de impostos, mão-de-obra abundante e barata e baixo custo de produção (LIMA, 2000).

Nos últimos 10 anos, os empreendimentos provenientes de programas e de projetos são de grande magnitude, e visam tornar o território fluido, intensificando o escoamento de mercadorias; alguns exemplos são: o programa Companhia Cearense de Transportes Metropolitanos - METROFOR, que tem seu valor estimado para conclusão de $\mathrm{R} \$$ 1.154.790.000,00 (SEXEX/CE, 2004), o Programa de Desenvolvimento do Turismo no Nordeste - PRODETUR, que incluiu, dentre outras obras, a ampliação do Aeroporto Pinto Martins, drenagens, pavimentação asfáltica, sinalização e obras complementares, principalmente ligadas à estruturação de rodovias do litoral. Para a execução do projeto, os recursos foram de aproximadamente US\$294,80 milhões, provenientes da União, do Banco Interamericano de Desenvolvimento (BID) e do Tesouro do Estado do Ceará (QUINTILIANO, 2008).

Outro exemplo é o Complexo Industrial e Portuário do Pecém (CIPP) (IFOTOS 3, 4, 5), que atualmente com a construção do Terminal de Múltiplas Utilidades (TMUT), contou com investimentos da ordem de $R \$ 400$ milhões, sendo que do total, $R \$ 125$ milhões foram bancados pelo próprio caixa estadual, e o restante, $R \$ 275$ milhões, foram financiados pelo BNDES (Banco Nacional de Desenvolvimento Econômico e Social). O banco também autorizou, no início do ano de 2014, um financiamento da ordem de $R \$ 630,5$ milhões, previsto para uma nova etapa da ampliação do Porto do Pecém (CEARÁ, 2014)

O Porto tem relevância econômica, visto que agrega uma série de atividades variadas, atuando tanto no âmbito de exportação como importação. Em entrevista concedida pelo coordenador de comercial Raul Neris Viana em dezembro de 2015, este afirmou que o Porto do Pecém é o maior exportador de frutas em âmbito nacional, sendo que a média de exportações chega a mais de mil contêineres/mês.

No complexo, há empresas diversas que operam em diferentes segmentos, como Wobben fabricante de aerogeradores (turbinas eólicas), de grande porte da América do Sul, instalada no Brasil em Dezembro de 1995. A Wobben é subsidiária 
da ENERCON GmbH (Alemanha), líder mundial em tecnologia eólica de ponta, e uma das líderes do mercado eólico mundial. Possui 3 unidades fabris, sendo 1 em Sorocaba/SP(pás e geradores), 1 no Pecém/CE (pás) e 1 em Juazeiro/BA (torres de concreto).

Nesse mesmo segmento, também está instalada a Aeris, empresa Nacional, fundada em 210, e fabricante de pás eólicas. Segundo informações do jornal O Povo, a empresa busca localizações estratégicas para suas sedes e a Região Nordeste concentra mais da metade do potencial eólico do Brasil. A opção pelo Ceará deveu-se principalmente às possibilidades proporcionadas (O POVO ON LINE, 2016) $)^{44}$.

Recebemos convites de outros estados, mas escolhemos o Ceará devido às condições que o Governo nos permitiu. Além disso, a mão de obra que tivemos aqui foi uma grande surpresa e é o que nos faz fincar cada vez mais as raízes no solo cearense, revelou Bruno Vilela, presidente da empresa de pás eólicas (O POVO, 2016).

Pela potencialidade, a localização e a oferta de mão de obra, o CIPP recebe muitos investimentos e a previsão é alargar mais ainda. Segundo Raul, há previsão para ampliação das atividades comerciais e industriais, principalmente devido à ampliação do Canal do Panamá ${ }^{45}$.

Atualmente abriga a Companhia Siderúrgica do Pecém (CSP) - das coreanas Dongkuk, Posco e a brasileira Vale - que investiu US $\$ 5,4$ bilhões, para torná-la operante. Com a sua operação parcial, o Ceará vendeu para o exterior 116,8\% a maisdo que no mesmo período de 2016 (O Povo, 2017).

"A expectativa é que, em operação plena, a CSP represente $12 \%$ do PIB e $48 \%$ do PIB Industrial do Estado. A geração de empregos alcançará 12 mil diretos e indiretos" (O Povo, 2017). ${ }^{46}$

\footnotetext{
${ }_{44}$ Matéria publicada no Jornal $O$ Povo on line em 7 de dezembro de 2016. Disponível em: http://www.opovo.com.br/noticias/economia/2016/12/aeris-energy-deve-gerar-3-mil-empregos-nopecem.html.

${ }^{45}$ A ampliação do Canal do Panamá visa converter o Panamá no centro logístico das Américas, passa a permitir a passagem de navios com capacidade para transportar até 13 mil contentores, três vezes mais do que até agora o que implicará no aumento de exportações.

46 Essa informações foram dadas por Raul Neris Viana (dezembro de 2015), coordenador de comercial, o Porto do Pecém, bem como estão disponível no Jornal O Povo on line numa matéria publicada em 4 de Abril de 2017 no link: http://www.opovo.com.br/jornal/economia/2017/04/companhia-siderurgica-do-pecem-einaugurada.html
} 
Foto 5 e 6: Complexo Industrial e Portuário do Pecém/CE.
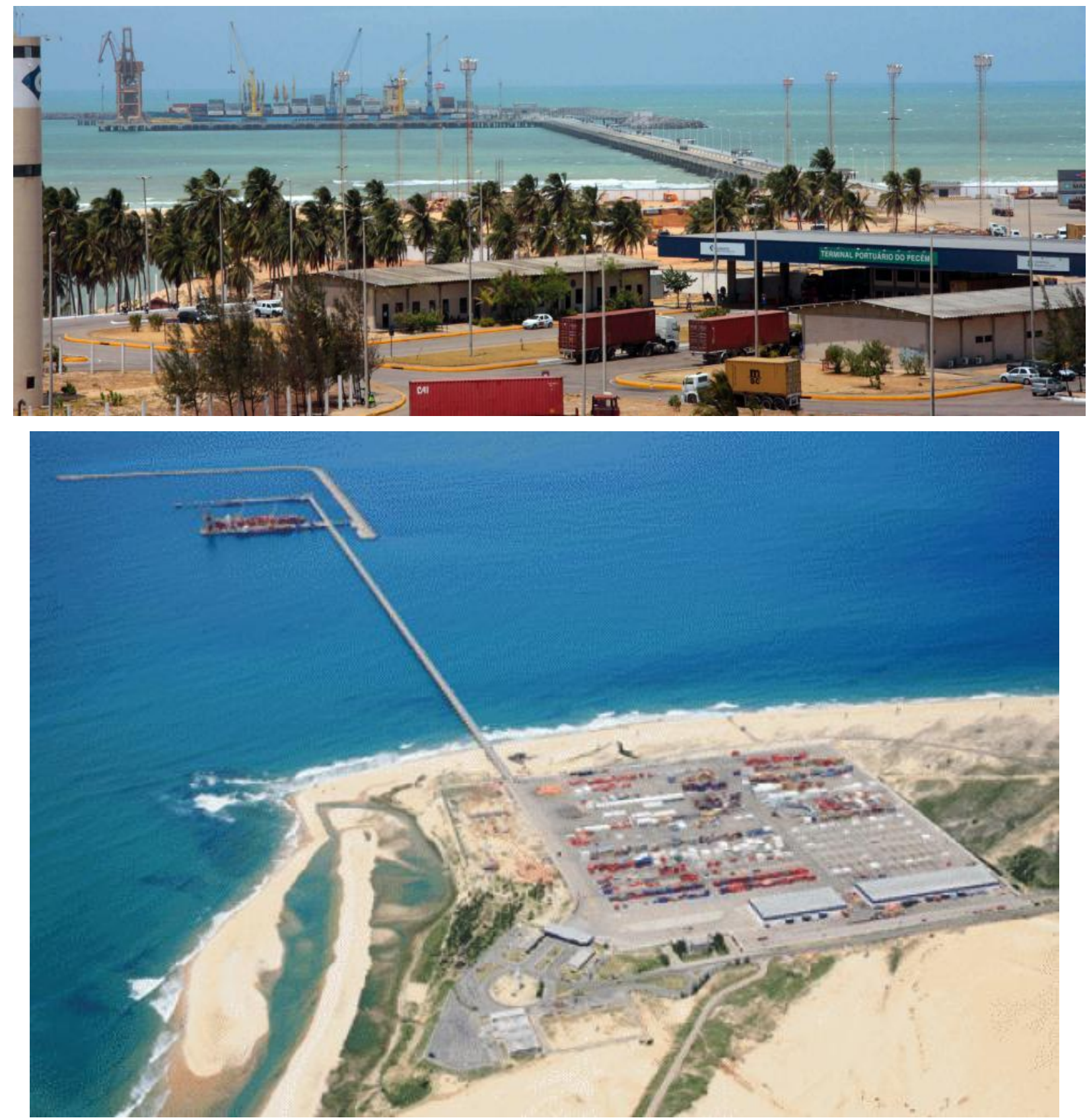

Fonte:http://www.dnocs.gov.br/ dnocs/var/images/galeria/_barragens/ceara/castanhao/cas tanhao/http://www.skyscrapercity.com/showthread.php?t=1286173

O CIPP também foi o local escolhido para abrigar uma matriz energética no Brasil, sendo construído o primeiro Terminal Flexível de Regaseificação de Gás Natural Liquefeito $(\mathrm{GNL})^{47}$. O projeto foi pioneiro no mundo e iniciou sua operação em 2009 (FOTO 7).

${ }^{47}$ Gás natural liquefeito (GNL) é o gás natural (GN) no estado líquido. A liquefação (passagem do estado gasoso para o líquido) ocorre depois do resfriamento do gás natural à temperatura de $162^{\circ} \mathrm{C}$ negativos. $O$ estado líquido reduz o volume do gás em cerca de 600 vezes, o que facilita o transporte. 
FOTO 7: Terminal Flexível de Regaseificação de Gás Natural Liquefeito

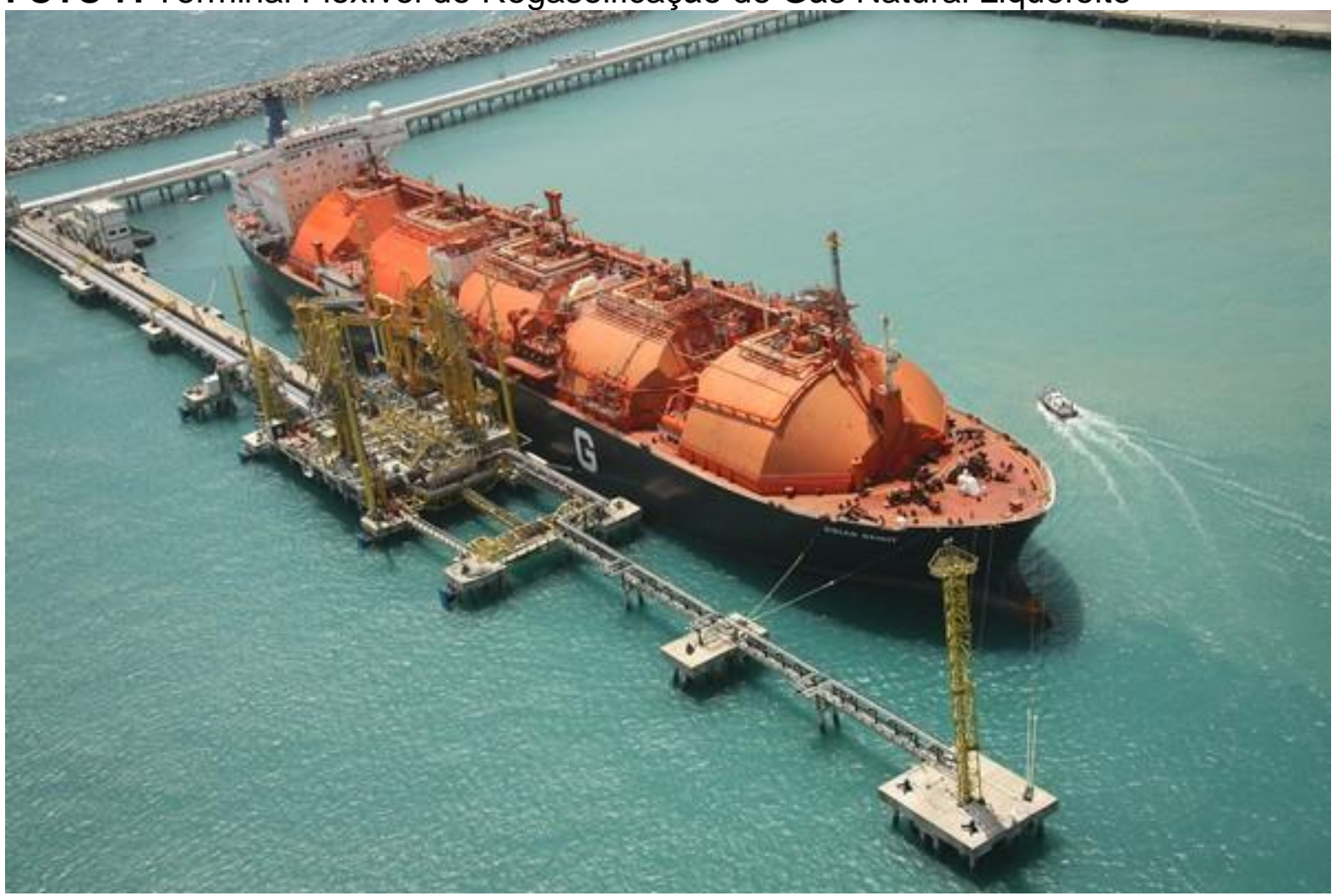

Fonte: http://www.petrobras.com.br/fatos-e-dados/recorde-de-operacoes-com-gas-naturalliquefeito-garante-suprimento-para-termicas.htm

Ano: 2015.

O terminal foi instalado no município de São Gonçalo do Amarante, e opera realizando o terminal transferência de GNL entre um navio supridor e um navio com planta de armazenamento e regaseificação a bordo. O uso dessa tecnologia está no Plano de Negócios da Petrobrás, e prevê a produção de 46 milhões de m³/dia para o abastecimento de termoelétricas, para a geração de energia elétrica nas usinas TermoCeará e TermoFortaleza, ambas no Ceará, e na Usina Jesus Soares Pereira, no Rio Grande do Norte (RELATÓRIO ANUAL, TRANSPECTRO, 2008).

Segundo a Transpectro (2008), a capacidade de regaseificação do Terminal de Pecém é de 7 milhões de $\mathrm{m}^{3} / \mathrm{dia}$ de gás; o equivalente a cerca da metade do consumo atual de gás natural destinado ao mercado de térmicas em todo o país. $E$ também representa um acréscimo de mais de $10 \%$ na oferta de gás natural ao mercado nacional, que é de 60 milhões de $\mathrm{m}^{3} / \mathrm{dia}$.

Ao chegar ao seu destino, o GNL é submetido a um processo físico de regaseificação, através da elevação da temperatura, para voltar à forma gasosa. Após o processo realizado na planta de regaseificação localizada dentro do próprio navio, o gás é injetado na malha de dutos operada pela Transpetro. (RELATÓRIO ANUAL, TRANSPETRO, 2008, p. 34). 
Vale ressaltar que a energia utilizada no Ceará, há cerca de dez anos atrás, era gerada em outros estados. Nesse tempo, foram investidos bilhões de dólares em geração de energia, incluindo eólica, gás e carvão. Hoje, o Ceará é autossuficiente na geração de energia e o terceiro maior gerador de energia de fonte eólica do país ${ }^{48}$ (CEARÁ, 2016).

No campo, há a ampliação de investimentos direcionados a projetos de irrigação e o Projeto de Transposição do Rio São Francisco, que teve seu planejamento inicial nos anos de 1990, e foi colocado em execução em 2003-2006 no primeiro mandato do governo Lula $^{49}$, tendo continuidade no mandato de Dilma Roussef.

O Projeto de Transposição tem como objetivo captar água do rio São Francisco e levá-la ao Semiárido Nordestino, no intuito de prover o abastecimento de agua às populações; assegurar safras agrícolas, atividades industriais e o turismo; evitar a migração da população rural para outras regiões; promover o crescimento das atividades produtivas; diminuir gastos públicos com medidas emergenciais durante as frequentes secas; garantir água para uma infraestrutura de reserva e distribuição já existente (açudes, rios e adutoras); enfim, segundo o Governo, promover o desenvolvimento (HENKES, 2014, p.1).

Nesse sentido, a pressão vertical dos setores industriais e do agronegócio acaba por fortalecer as horizontalidades nas localidades onde há carência de investimentos para subsidiar o básico. Pois, o empreendimento subsidiou Vilas Produtivas Rurais (VPRs) nos estados de Pernambuco, Ceará e Paraíba.

\footnotetext{
${ }^{48}$ Página oficial do Governo do Estado do Ceará - Disponível em: http://www.ceara.gov.br/sala-deimprensa/noticias/17928--governo-do-ceara-assina-memorando-com-a-kogas-para-instalacao-determinal-gnl-no-pecem.

${ }^{49}$ Desde o século XIX, a transposição do rio São Francisco vem sendo defendida como a solução para os problemas do Nordeste a primeira proposta, ainda que muito vaga, tratava da abertura de um canal que levasse água do rio São Francisco ao rio Jaguaribe, idealizada pelo ouvidor José Raimundo dos Passos Barbosa, em 1818. Pouco tempo depois, Dom Pedro II também passou a defender a transposição como o meio mais eficaz de lidar com as secas no Nordeste e o Projeto de Transposição do rio São Francisco começou a ser delineado. Durante o governo de Juscelino Kubitschek foi arquivado. No governo de Figueiredo foi resgatado e arquivado novamente devido a mortandade de peixes. No Governo Itamar (1992-1995), a ideia voltou à cena, tendo inicio os estudos de EIA/RIMA. No governo de FHC os estudos foram reavaliados, mas somente no primeiro mandato do governo Lula é se iniciaram as obras de construção da transposição (HENKES, 2014).
} 
As VPRs são constituídas de casas de $99 \mathrm{~m}^{2}$, postos de saúde, escolas, praças, quadras poliesportivas, campo de futebol, centro comunitário, além de rede de água, esgoto e energia elétrica. Os moradores também recebem setores produtivos, com no mínimo cinco hectares por beneficiário, sendo um deles destinado à irrigação.

Segundo o site do Ministério da Integração, as famílias recebem visitas periódicas dos técnicos do ministério, e participam de capacitações e oficinas, com o objetivo de garantir a reinserção e a organização socioeconômica das comunidades (BRASIL, Ministério da Integração Nacional, 2017).

No que se refere à distribuição da água, esta segue por meio de dois eixos: o Eixo Norte (Latitude Sul $8^{\circ} 32^{\prime} 41,1^{\prime \prime}$ e Longitude Oeste $\left.39^{\circ} 27^{\prime} 15,2^{\prime \prime}\right)$, que visa atingir Pernambuco (PE), Ceará (CE), Paraíba (PB) e Rio Grande do Norte (RN) dos quais somente Pernambuco faz parte da bacia; e o Eixo Leste (Latitude Sul $8^{\circ}$ $49^{\prime} 37,7^{\prime \prime}$ e Longitude Oeste $\left.38^{\circ} 24^{\prime} 43,3^{\prime \prime}\right)$, que beneficiará parte do Sertão e as regiões agrestes de Pernambuco e da Paraíba (IMAPA, 6)(HENKES, 2014). 


\section{Mapa 6: Transposição do Rio São Francisco}
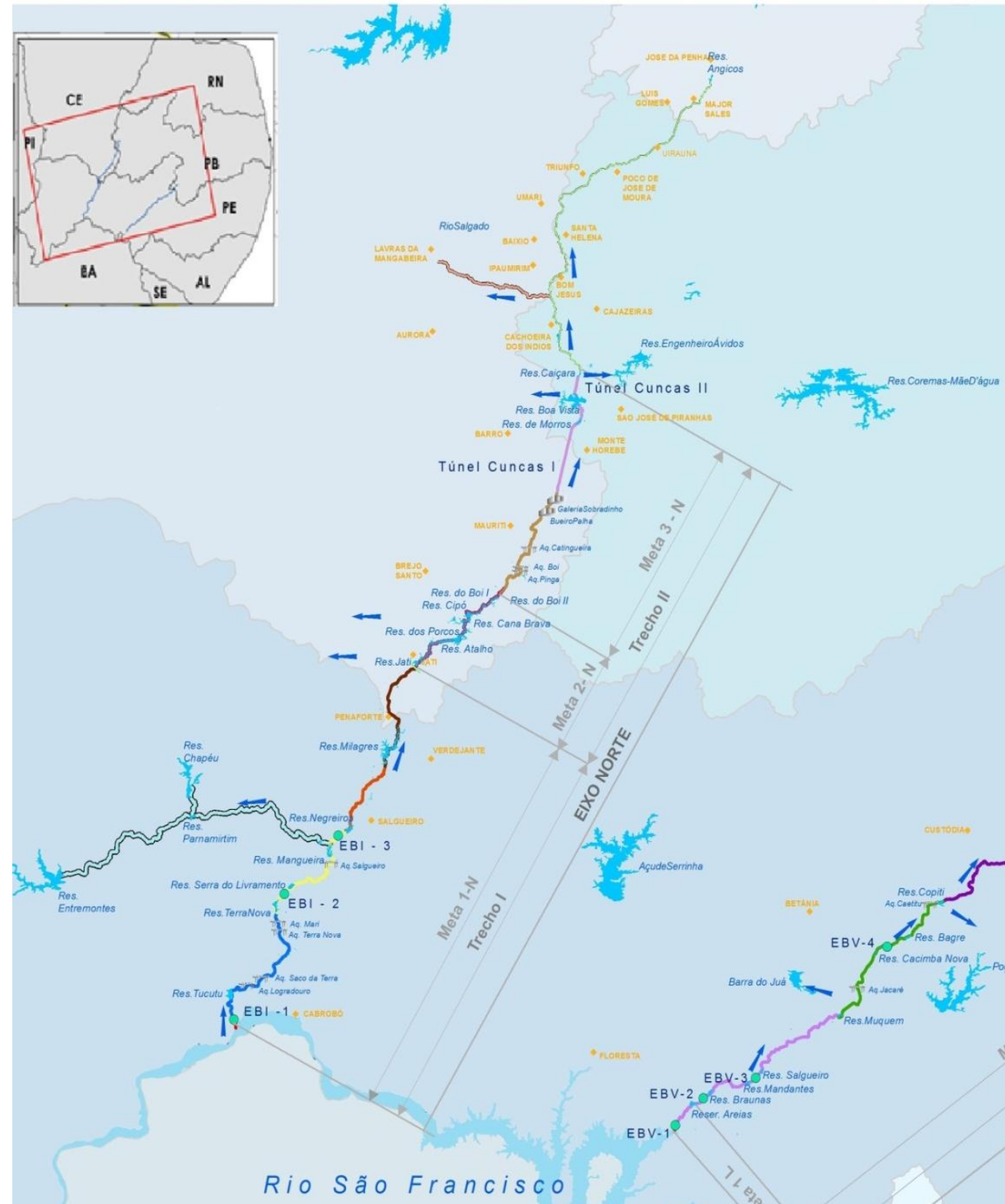

Rio São Francisco

Disponível em: http://www.mi.gov.br/web/projeto-sao-francisco/o-andamento-das-obras 
Atualmente, de acordo com as informações contidas no site do Ministério da Integração Nacional, a execução física do empreendimento apresenta 96,28\% de conclusão nos dois eixos, sendo 94,81\% no Eixo Norte, e o Eixo Leste já está com $100 \%$. Os dados são referentes aos avanços registrados em março deste ano.

A situação das obras apresentam os seguintes dados: Os dois eixos de transferência de água são organizados em seis trechos de obras (Metas $1 \mathrm{~N}, 2 \mathrm{~N}, 3 \mathrm{~N}$, $1 \mathrm{~L}, 2 \mathrm{~L}$ e $3 \mathrm{~L}$ ). Essas etapas são compostas pelos antigos 16 lotes do projeto.

\section{EIXO LESTE}

META $1 L$ - Meta Piloto (16 quilômetros): compreende a captação no reservatório de Itaparica até o reservatório Areias, ambos em Floresta (PE). A Meta 1L está 100\% finalizada e está localizada em Floresta (PE).

META 2L - (167 quilômetros): inicia na saída do reservatório Areias, em Floresta $(\mathrm{PE})$, e segue até o reservatório Barro Branco, em Custódia (PE). A Meta 2L está com $100 \%$ de execução física. O trecho passa pelos municípios de Floresta (PE), Custódia (PE) e Betânia (PE).

META 3L - (34 quilômetros): Este trecho está situado entre o reservatório Barro Branco, em Custódia (PE), e o reservatório Poções, em Monteiro (PB). A Meta 3L está $100 \%$ concluída. A etapa passa pelos municípios de Custódia (PE), Sertânia (PE) e Monteiro (PB).

\section{EIXO NORTE}

META 1N - (140 quilômetros): Vai da captação do Rio São Francisco, no município de Cabrobó (PE), até o reservatório de Jati(CE). A Meta $1 \mathrm{~N}$ apresenta 92,3\% de execução física. As obras passam pelos municípios de Cabrobó (PE), Terra Nova (PE), Salgueiro (PE), Verdejante (PE) e Penaforte (CE).

META 2N - (39 quilômetros): começa no reservatório Jati, no município de Jati (CE), e termina no reservatório Boi II, no município de Brejo Santo (CE). A Meta 2N 
apresenta 99,1\% de execução física. Este trecho passa pelos municípios de Jati, Brejo Santo e Mauriti, no estado do Ceará.

META 3N - (81 quilômetros): estende-se do reservatório Boi II, no município de Brejo Santo (CE), até o reservatório Engenheiro Ávidos, no município de Cajazeiras (PB). A Meta $3 \mathrm{~N}$ apresenta $98,2 \%$ de execução física. Este trecho passa pelos municípios de Brejo Santo (CE), Mauriti (CE), Barro (CE), Monte Horebe (PB), São José de Piranhas (PB) e Cajazeiras (PB) (Mapa 6).

O orçamento estimado foi revisto, e a previsão atual é de que sejam gastos $\mathrm{R} \$ 8$ bilhões (BRASIL, Ministério da Integração Nacional, 2016).

No setor da educação, houve a expansão do ensino técnico, como meio de qualificar profissionais para o atendimento das novas demandas, ligadas à formação da empregabilidade para os setores da economia que, via de regra, cresceu exponencialmente devido à abertura comercial mundial.

Nesse sentido Milton Santos diz que:

À medida que as trocas se intensificam, as técnicas se desenvolvem para que o grupo se imponha no comercio, ou são adaptadas para que ele seja menos perdedor em uma cooperação cada vez mais desigual. Desde então, as transferências de técnicas frequentemente aparecem como meio de aumentar a produtividade e a produção e buscar, desse modo, escapar a uma situação de inferioridade" (SANTOS, 2012, p. 220).

Assim, têm-se de um lado, gastos e investimentos para garantir, sobretudo, o atendimento ao mercado com altos valores destinados a construção dessas escolas e, por outro lado, evidencia-se o pouco investimento nas escolas regulares para a garantia de uma melhor qualidade de ensino.

Desse modo, "da totalidade dos objetos surgidos uns tem vocação simbólica, mas a maior parte nasce com uma vocação mercantil" (SANTOS, 2008, p.122). O que acarreta a sua difusão em maior escala, mas não uniformemente.

Por isso, o território cearense apresenta espaços luminosos, ou subespaços dinâmicos, reconhecidos como pólos de investimentos públicos e privados, que são respectivamente a Região Metropolitana de Fortaleza (RMF) e Litoral, Baixo e Médio Jaguaribe, Vale do Acaraú e municípios de Juazeiro do Norte e Crato (LIMA, 2012) e 
os espaços opacos, que são menos densos em técnica, mas recebem os impactos do restante do território, do país e do mundo.

A tabela 1 mostra os estabelecimentos comerciais, distribuídos em todo o território. De acordo com os dados da tabela, as maiores concentrações estão na Capital - Fortaleza, Caucaia, Maracanaú, Sobral, Iguatu, Crato e Juazeiro do Norte.

Tabela 1: Estabelecimentos comerciais, segundo os setores econômicos e os gêneros de atividades - Ceará - 2007/2012.

\begin{tabular}{|c|c|c|}
\hline \multirow[t]{2}{*}{ Setores e Gêneros de atividades } & \multicolumn{2}{|c|}{$\begin{array}{c}\text { Estabelecimentos } \\
\text { comerciais }\end{array}$} \\
\hline & 2007 & 2012 \\
\hline Total & 87.022 & 135.370 \\
\hline Atacadista & 3.429 & 3.727 \\
\hline Varejista & 83.146 & 131.194 \\
\hline Mercadorias em geral(1) & 30.055 & 32.404 \\
\hline Tecidos, vestuários e artigos de armarinho & 15.069 & 28.539 \\
\hline Material para construção & 6.292 & 9.738 \\
\hline Produtos de gêneros alimentícios & 3.160 & 6.328 \\
\hline Peças e acessórios para veículos, motocicletas e motonetas & 3. 636 & 7.061 \\
\hline Perfumaria e produtos farmacêuticos & 3.139 & 8.255 \\
\hline Artigos de decoração e utilidades domésticas & 3.016 & 4.596 \\
\hline Combustíveis, lubrificantes e gás liquefeito de petróleo(GLP) & 1.783 & 2.634 \\
\hline Máquinas, equipamentos e materiais de informática e comunicação & 1.730 & 4.858 \\
\hline Livros, artigos de papelaria, jornais e revistas & 1.489 & 2.356 \\
\hline Bebidas & 1.373 & 2.841 \\
\hline Calçados, artigos de couro e viagem & 1.325 & 2.062 \\
\hline Ótica, relojoaria e joalheria & 1.277 & 2.472 \\
\hline $\begin{array}{l}\text { Máquinas, aparelhos e equipamentos elétro-eletrônicos de uso } \\
\text { doméstico e pessoal }\end{array}$ & 1.153 & 1.596 \\
\hline Medicamentos veterinários, artigos para animais, rações animais & 1.068 & 1.767 \\
\hline Artigos de souveniers, bijuterias e artesanatos & 997 & 1.570 \\
\hline Bicicletas, triciclos e suas peças e acessórios & 969 & 1.182 \\
\hline Automóveis, camionetas, utilitários, motocicletas e motonetas & 812 & 1.117 \\
\hline Outros & 4.763 & 5.454 \\
\hline Reparação de veículos e de objetos pessoais e de uso doméstico & 447 & 449 \\
\hline
\end{tabular}

FONTE: Secretaria da Fazenda - SEFAZ in Instituto de Pesquisa e Estatística Econômica do Ceará/ IPECE.

Nessas localidades, há uma maior predominância de objetos técnicos; o que requer maiores investimentos em vários setores, inclusive na educação técnica. 
Também há um número maior de escolas de ensino médio técnico profissional integrado e de empresas ou organizações de educação.

Esses locais são pontos onde a comercialização do sistema regido pelo mercado se propaga em maior escala, há a difusão dos avanços técnicos-científicosinformacionais, tais como os serviços modernos interligados à informática, escritórios, redes de transportes, empresas de telecomunicações, bem como uma maior quantidade de indústrias, hospitais, clínicas de saúde, universidades, faculdades e centros de formação técnica, dentre outros.

O Estado, como instituição política, que tem a capacidade de agir e normatizar a totalidade do território aparece como financiador desse processo, com políticas territoriais que induzem a sua efetivação, pois vem dotando o território cearense de objetos que visam atender, em primeiro lugar, aos interesses do capital.

Tais objetos são inseridos no território à medida que a totalidade vai se empiricizando no processo de formação territorial de um país, e vai forjando, conjuntamente aos conteúdos do território nacional, novos objetos e sistemas funcionais, reorganizando o território para continuar a servir a diferentes usos por esses sistemas e pela sociedade (SOUZA, 2013) ${ }^{50}$.

\section{A EPMI na totalidade}

A constituição dos objetos está sempre em transformação, expansão e modernização, expressando diferentes dinâmicas da totalidade social do tempo presente. Assim, tais objetos hoje inseridos no território cearense são provenientes do atual processo de globalização, em que as empresas mundiais ditam as regras do mercado.

A escola é parte dessa totalidade e, por isso, um objeto passível de mudanças, pois a medida que é transmissora de uma dada cultura, também atende aos propósitos e objetivos do mercado.

\footnotetext{
50 Discussão teorizada pela professora Maria Adélia Aparecida de Souza em aulas, cursos e conferências públicas, em várias localidades do País e do mundo.
} 
O que acontece é que esses objetivos nem sempre estão de acordo com o propósito de uma ética que há séculos se busca, por meio da educação, ou seja, a formação humana, no seu sentido completo, em que o conhecimento seja a base para o entendimento daquilo que deu base à formação da humanidade, no intuito de saber como a história se processou e como, a partir disso, pode-se pensar na sua condução para uma forma de convivência mais equânime.

A educação, como existe hoje, se constituiu nos moldes da assimilação de pensamentos, comportamentos, técnicas, normas e tecnologias desenvolvidas em diferentes épocas e de diferentes modos.

A difusão desses pensamentos, comportamentos, técnicas, normas e tecnologias estão diretamente atrelados ao poder dos agentes sociais ${ }^{51}$. Portanto, ao invés de proporcionar uma educação voltada à formação humana, por meio de políticas educacionais que possam concretizar essa prática, passa a cumprir o papel de mediador de um poder corporativo, sob o planejamento do Estado, porém, exercido pela ação dos agentes hegemônicos da economia.

É nesses termos que as políticas de educação do Estado do Ceará têm sido conduzidas, de modo a efetivar e fazer funcionar esse sistema, estimulando a sua permanente renovação, ou seja, criando normas, leis e novos objetivos, a fim de atender as demandas do território, que em sua maioria estão atreladas ao mercado.

Este processo é de fácil constatação quando se busca compreender o aumento das escolas técnicas profissionais no território.

Nos últimos oito anos, o número de escolas técnicas profissionais estaduais mais que triplicou (Tabela 2); o que leva a crer que esse aumento tem estreita relação com as demandas provenientes dos sistemas de engenharia, que fornecem as condições para mobilizarem novas técnicas, uma vez que a reprodução do capital exige uma contínua reestruturação e refuncionalização.

\footnotetext{
${ }^{51}$ Um exemplo que pode ser dado, foi a imposição da cultura europeia aos índios brasileiros.
} 
Tabela 2- Desenvolvimento da Educação Profissional no Ceará, de 2008 à 2014.

\begin{tabular}{ccccc} 
Ano & $\begin{array}{c}\text { Escolas em } \\
\text { funcionamento } \\
\left(\mathbf{N N}^{\mathbf{0}}\right)\end{array}$ & $\begin{array}{c}\text { Municípios } \\
(\mathbf{N} \mathbf{0})\end{array}$ & $\begin{array}{c}\text { Cursos } \\
(\mathbf{N})\end{array}$ & $\begin{array}{c}\text { Matrícula Inicial } \\
\left(\mathbf{1}^{\mathbf{a}}, \mathbf{2}^{\mathbf{a}} \mathbf{e}\right.\end{array}$ \\
\hline 2008 & 25 & 20 & 4 & 4.181 \\
\hline 2009 & 51 & 39 & 13 & 11.279 \\
\hline 2010 & 59 & 42 & 18 & 17.342 \\
\hline 2011 & 77 & 57 & 43 & 23.753 \\
\hline 2012 & 92 & 71 & 51 & 29.958 \\
\hline 2013 & 97 & 74 & 51 & 35.522 \\
\hline 2014 & 106 & 82 & 53 & 40.979 \\
\hline 2015 & 111 & 82 & 53 & \\
\hline
\end{tabular}

Fonte: Secretaria da Educação do Ceará/Coordenadoria de Educação Profissional Sistema de Gestão Escolar - Data-base Censo Escolar.

Segundo dados da Secretaria da Educação do Ceará/Coordenadoria de Educação Profissional / Sistema de Gestão Escolar - Data-base Censo Escolar (2014), atualmente $12 \%$ dos alunos do ensino médio estão nas escolas de educação profissional, o que representa um total de 40.979 alunos, conforme indica a oferta de matrícula (Gráfico 1). 


\section{Gráfico 1: Número de matrículas na Educação Técnica de Nível Médio Integrada de 2008 à 2014.}

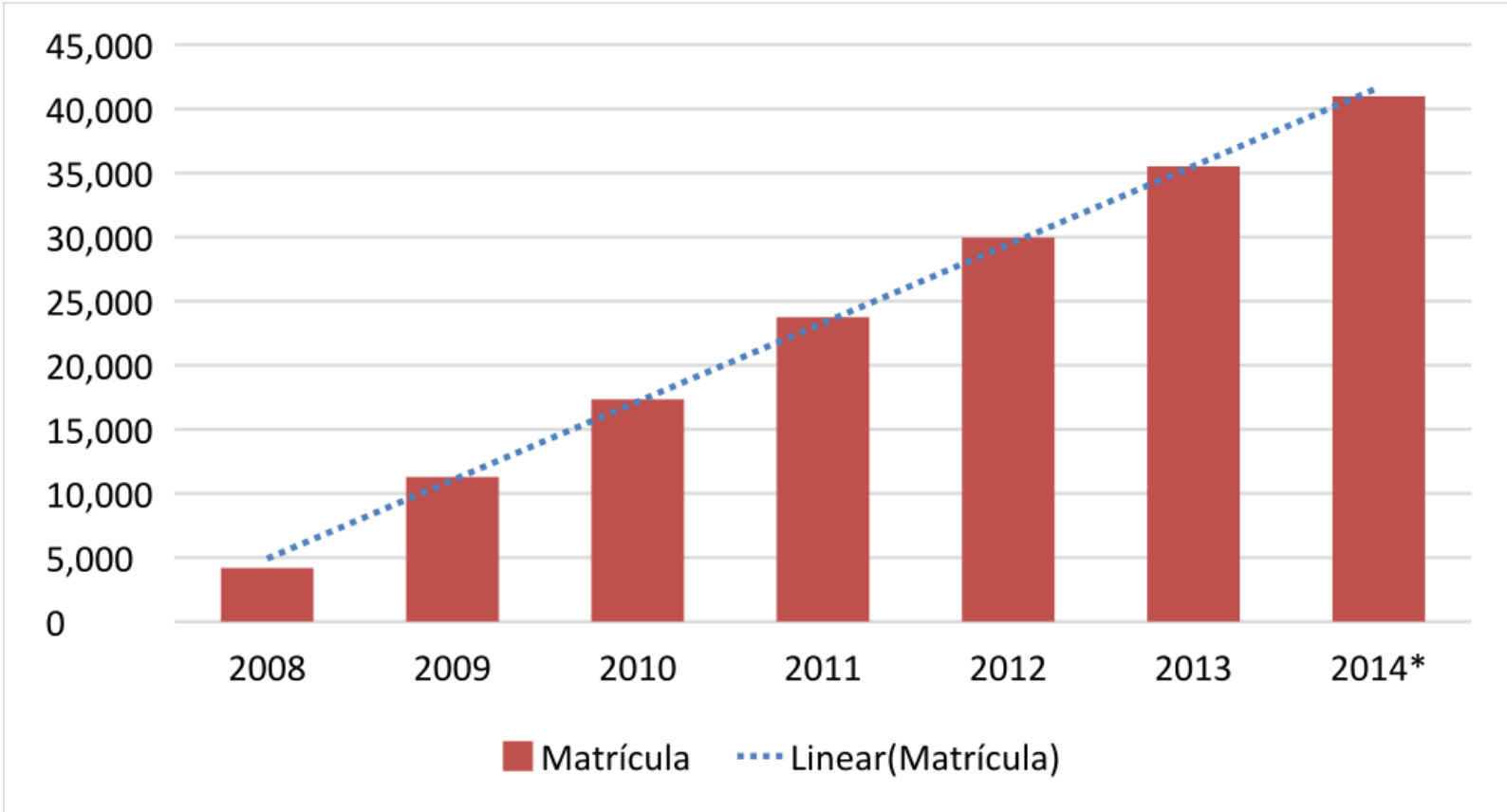

Fonte: Secretaria da Educação do Ceará/Coordenadoria de Educação Profissional / Sistema de Gestão Escolar - Data-base Censo Escolar.

*Das 40.979 matrículas, 316 foram capturadas no SIGE em novembro de 2014, considerando que duas escolas regulares do ano de 2014 foram efetivadas como Profissionais após a Data-base do Censo Escolar.

Neste sentido, Winckler; Santagada (2012), dizem que a educação profissional técnica de nível médio, torna-se uma preocupação governamental, a partir da retomada do desenvolvimento do mercado interno e das pressões de setores empresariais.

Segundo Pompermeyer et al., (2011), órgãos e institutos vinculados à qualificação do trabalhador apontam pouca mão de obra e baixa qualificação em áreas de engenharia ligadas à infraestrutura, na indústria da construção civil e naval, na área tecnológica de prospecção de petróleo, na agricultura empresarial, dentre outras.

De acordo com Santos (2000), é a irradiação do meio técnico-científicoinformacional que agrega nos territórios fixos e fluxos, que são acolhidos e incorporados - mas, não uniformemente, visto que há uma seletividade na expansão desse meio, fazendo com que essa irradiação ocorra mais em alguns locais do que em outros - impondo ao território mudanças estruturais.

$\mathrm{Na}$ atualidade, essa é a configuração do território usado cearense, que demonstra uma concepção dialética no seu modo de uso, e que chama atenção 
para as consequências geradas pela implantação de novos objetos técnicos relacionados à Educação Técnica Profissional de Nível Médio Integrado.

Por conta da "ação racional (ação precisa, sequiosa de resultados), como ação instrumental, sobre a ação simbólica" (SANTOS, 2012, p. 224), é que a opção pela Educação Técnica Profissional torna-se tão necessária. "Cada vez mais há uma criação cotidiana do homem ignorante, que leva regiões inteiras a ignorar o que elas são, sempre que não conhecem o segredo do funcionamento dos respectivos objetos e ações". (SANTOS, 2012, p. 227).

É nesse contexto que a expansão das Escolas Técnicas Profissionais Integradas é um dado do uso corporativo do território pelo poder, tanto do Estado, como das instituições internacionais e nacionais, que buscam certo controle intelectual de determinadas parcelas da população, como também buscam outras finalidades, principalmente, com determinações neoliberais voltadas à ampliação dos circuitos de reprodução do capital.

Os cursos ofertados por estas escolas (Quadro 5) sublinham as intenções, visto que uma parte considerável da oferta é direcionada ao atendimento das demandas econômicas, impulsionadas pela ordem mundial. Pelo uso do território, as demandas são criadas e acarretam novas demandas. 


\section{Quadro 5: Cursos e Números de Cursos ofertados nas Escolas Profissionais Técnica de Nível Médio}

\begin{tabular}{|c|c|c|c|}
\hline Cursos & № & & № \\
\hline 1. Técnico em Enfermagem & 50 & 27. Téc. em Des. de Construção Civil & 3 \\
\hline 2. Técnico em Informática & 49 & 28. Técnico em Nutrição e Dietética & 3 \\
\hline 3. Téc. em Redes de Computadores & 40 & 29. Técnico em Química & 3 \\
\hline 4. Técnico em Administração & 30 & 30. Técnico em Manutenção Automotiva & 3 \\
\hline 5. Técnico em comércio & 26 & 31. Técnico em Fruticultura & 3 \\
\hline 6. Técnico em Edificações & 17 & 32. Técnico em Fabricação Mecânica & 2 \\
\hline 7. Técnico em Finanças & 16 & 33. Técnico em Secretariado & 2 \\
\hline 8. Técnico em Eletrotécnica & 13 & 34. Técnico em Instrução de Libras & 2 \\
\hline 9. Técnico em Agropecuária & 13 & 35. Técnico em Trans. Imobiliárias & 2 \\
\hline 10. Técnico em Agronegócio & 11 & 36. Téc. em Prod. de Áudio e Vídeo & 2 \\
\hline 11. Técnico em Agroindústria & 11 & 37. Técnico em Paisagismo & 2 \\
\hline 12. Técnico em Contabilidade & 10 & 38. Técnico em Móveis & 2 \\
\hline 13. Técnico em Logística & 9 & 39. Técnico em Regência & 2 \\
\hline 14. Técnico em Hospedagem & 9 & 40. Técnico em Automação Industrial & 1 \\
\hline 15. Técnico em Aquicultura & 8 & 41. Téc. em Modelagem do Vestuário & 1 \\
\hline 16. Técnico em Eletromecânica & 8 & 42. Técnico em Produção de Moda & 1 \\
\hline 17. Técnico em Mecânica & 6 & 43. Técnico em Portos & 1 \\
\hline 18. Técnico em Secretaria Escolar & 5 & 44. Técnico em Petróleo e Gás & 1 \\
\hline 19. Técnico em Estética & 5 & 45. Técnico em Mineração & 1 \\
\hline 20. Técnico em Massoterapia & 4 & 46. Técnico em Têxtil & 1 \\
\hline 21. Técnico em Eventos & 4 & 47. Técnico em Vestuário & 1 \\
\hline 22. Técnico em Agrimensura & 4 & 48. Técnico em Biotecnologia & 1 \\
\hline 23. Téc. em desenho de const. Civil & 4 & 49. Técnico em Floricultura & 1 \\
\hline 24. Meio Ambiente & 4 & 50. Técnico em Saúde Bucal & 1 \\
\hline 25. Téc. em Segurança do Trabalho & 3 & 51. Técnico em Gestão cultural & 1 \\
\hline 26. Técnico em Guia de Turismo & 3 & & \\
\hline
\end{tabular}

Fonte: Secretaria de Educação do Estado do Ceará - SEDUC, 2015.

Ao contrapor os dados relativos às atividades econômicas e a localização das escolas profissionais com seus respectivos cursos, é possível fazer uma leitura do uso do território cearense pela educação técnica profissional, visto que os cursos ofertados seguem em sua maioria a lógica econômica transnacional, em que a reestruturação dos espaços vincula-se à organização das relações econômicas do território nacional e, concomitantemente, à economia globalizada.

Rochefort apud Lemos (1999, p. 29-30) salienta que "hoje as empresas multiplicam as atividades exigidas antes e depois da produção e que não pertencem mais a seu âmbito".

Neste sentido, tem-se, atualmente, no Estado do Ceará, o setor terciário de comércio e serviços $70,2 \%$ como preponderantes, seguidos pela indústria, $23,6 \%$ e a agropecuária 6,2\% (IPECE, 2012). 
Ao analisar a lista de cursos ofertados, verifica-se também a predominância nos setores de serviços e comércio, seguidos pela atividade industrial e agropecuária.

Daí a reflexão sobre o uso do território, sobre a maior influência dos agentes hegemônicos e a condução da educação. Entretanto, verifica-se que também há vários cursos de grande importância, como por exemplo, os relacionados às áreas de saúde; o que demonstra o uso do espaço banal por todos e, portanto, o atendimento das demandas fundamentais para o social.

O quadro 2: cursos e número de cursos ofertados e as tabelas 3 e 4: apresentam as empresas comerciais, classe e gênero de indústrias e sua distribuição no Estado, demonstrando a simultaneidade do aumento de determinados setores da atividade econômica e o surgimento e a ampliação das escolas técnicas profissionais de nível médio.

Tabela 3: Indústria de transformação - Ceará - 2007/2012

\begin{tabular}{l|ll}
\hline \multicolumn{1}{c|}{ Classes e gêneros de indústria } & \multicolumn{2}{c}{$\begin{array}{c}\text { Indústrias de } \\
\text { transformação }\end{array}$} \\
\hline & \multicolumn{2}{c}{$\mathbf{2 0 0 7}$} \\
\hline Total & 12.413 & 25.626 \\
Minerais não metálicos & 1.106 & 1.400 \\
Metalurgia & 785 & 1.900 \\
Mecânica & 319 & 238 \\
Material elétrico, eletrônico e de comunicação & 124 & 405 \\
Material de transporte & 77 & 148 \\
Madeira & 493 & 762 \\
Mobiliário & 611 & 1.504 \\
Papel e papelão & 89 & 210 \\
Borracha & 76 & 136 \\
Couros, peles e produtos similares & 193 & 687 \\
Química & 321 & 449 \\
Produtos farmacêuticos e veterinários & 25 & 21 \\
Perfumaria, sabões e velas & 165 & 216 \\
Material plástico & 208 & 333 \\
Têxtil & 475 & 635 \\
Vestuário, calçados, artefatos de tecidos, couros e peles & 3.725 & 9.817 \\
Produtos alimentares & 2.537 & 4.319 \\
Bebidas & 194 & 244 \\
Fumo & 2 & 2 \\
Editorial e gráfica & 577 & 1.294 \\
Diversos & 311 & 906 \\
\hline
\end{tabular}

Fonte: Secretaria da Fazenda - SEFAZ. in Instituto de Pesquisa e Estatística Econômica do Ceará/ IPECE. 
Tabela 4: Empresas industriais - Região metropolitana de Fortaleza e municípios selecionados Ceará - 2007/2012

\begin{tabular}{|c|c|c|c|c|c|c|c|c|c|c|}
\hline \multirow{3}{*}{ Municípios } & \multicolumn{10}{|c|}{ Empresas industriais } \\
\hline & \multicolumn{2}{|l|}{ Total } & \multicolumn{2}{|c|}{ Extr. mineral } & \multicolumn{2}{|c|}{ Constr. civil } & \multicolumn{2}{|c|}{ Utili. pública } & \multicolumn{2}{|c|}{ Transformação } \\
\hline & 2007 & 2012 & 2007 & \begin{tabular}{|l|}
2012 \\
\end{tabular} & 2007 & 2012 & 2007 & 2012 & 2007 & 2012 \\
\hline $\begin{array}{l}\text { Ceará } \\
\text { RMF (1) }\end{array}$ & 15.138 & 30.324 & 195 & 297 & 2.431 & 3.459 & 99 & 199 & 12.413 & 25.626 \\
\hline Fortaleza & 7.677 & 15.005 & 16 & 18 & 1.582 & 1.970 & 41 & 61 & 6.038 & 12.617 \\
\hline Caucaia & 509 & 1.394 & 15 & 22 & 39 & 81 & 7 & 7 & 448 & 1.250 \\
\hline Maracanaú & 594 & 1.275 & 1 & 4 & 40 & 83 & 3 & 5 & 550 & 1.131 \\
\hline Eusébio & 312 & 520 & 1 & 2 & 58 & 100 & - & 2 & 253 & 368 \\
\hline Maranguape & 169 & 396 & - & 2 & 4 & 23 & - & 1 & 165 & 366 \\
\hline Aquiraz & 184 & 343 & 9 & 11 & 25 & 44 & 5 & 3 & 145 & 278 \\
\hline Pacatuba & 76 & 283 & - & 2 & 10 & 15 & 3 & 1 & 63 & 262 \\
\hline Horizonte & 105 & 261 & 4 & 1 & 9 & 21 & 1 & 3 & 91 & 227 \\
\hline Pacajus & 77 & 258 & - & 1 & 3 & 13 & - & - & 74 & 236 \\
\hline Cascavel & 97 & 237 & - & 1 & 5 & 16 & 1 & - & 91 & 217 \\
\hline Itaitinga & 59 & 151 & 2 & 8 & 7 & 16 & - & - & 50 & 120 \\
\hline $\begin{array}{l}\text { S. Gonçalo do } \\
\text { Amarante }\end{array}$ & 25 & 121 & - & 5 & 3 & 24 & 3 & 9 & 19 & 81 \\
\hline Pindoretama & 32 & 93 & - & - & 2 & 4 & - & - & 30 & 86 \\
\hline Chorozinho & 13 & 57 & - & 3 & 1 & 2 & - & - & 12 & 52 \\
\hline Guaiúba & 18 & 51 & - & 1 & 2 & 2 & - & - & 16 & 46 \\
\hline \multicolumn{11}{|c|}{ Municípios selecionados (2) } \\
\hline Juazeiro do $\mathrm{N}$. & 541 & 1.280 & 2 & 2 & 84 & 106 & 2 & 1 & 453 & 1.117 \\
\hline Sobral & 284 & 483 & 12 & 14 & 43 & 66 & 2 & 3 & 227 & 387 \\
\hline Iguatu & 267 & 405 & 1 & 4 & 56 & 52 & 4 & 4 & 206 & 331 \\
\hline Crato & 198 & 343 & 1 & 6 & 40 & 30 & 2 & 3 & 155 & 287 \\
\hline Russas & 170 & 301 & 2 & 4 & 15 & 16 & 1 & - & 152 & 276 \\
\hline Quixada & 108 & 241 & 1 & 2 & 21 & 37 & - & 1 & 86 & 197 \\
\hline Aracati & 93 & 222 & 2 & 3 & 3 & 17 & 5 & 9 & 83 & 188 \\
\hline Tianguá & 102 & 211 & 1 & - & 27 & 50 & 1 & 3 & 73 & 150 \\
\hline Limoeiro do N. & 149 & 209 & 4 & 6 & 17 & 25 & - & - & 128 & 177 \\
\hline Quixaramobim & 93 & 205 & 1 & 1 & 15 & 26 & - & - & 77 & 173 \\
\hline Crateús & 65 & 182 & - & 3 & 5 & 28 & - & - & 60 & 149 \\
\hline Itapipoca & 87 & 169 & 1 & 2 & 2 & 9 & - & - & 84 & 156 \\
\hline Jaguaruana & 109 & 152 & 6 & 7 & 1 & 4 & - & - & 102 & 139 \\
\hline Barbalha & 68 & 139 & 2 & 4 & 14 & 15 & - & - & 52 & 116 \\
\hline Morada Nova & 72 & 132 & 1 & 1 & 5 & 16 & 1 & - & 65 & 115 \\
\hline
\end{tabular}

Fonte: Secretaria da Fazenda - SEFAZ. in Instituto de Pesquisa e Estatística Econômica do Ceará/ IPECE.

(1) os municípios de Cascavel e Pindoretama passaram a integrar a Região Metropolitana de Fortaleza em 2009. (2) Municípios com maior número de indústrias, exclusive os da RMF.

Disponível em: http://www2.ipece.ce.gov.br/publicacoes/ceara_em_numeros/2013/economico/04_018_Indu stria.pdf.

Esta correspondência espacial parece indicar, dentre tantas, uma das expressões territoriais de algumas das perversidades das ações seletivas e corporativas do capitalismo. 
Assim, tem-se, de um lado, o analfabetismo (Mapa 7), a baixa qualidade das escolas regulares, com déficits que perpassam desde infraestrutura ${ }^{52}$ até a formação humana dos profissionais ${ }^{53}$, baixa qualidade do ensino público estadual ${ }^{54}$, abandono e distorção idade série ${ }^{55}$. Por outro lado, os investimentos na educação técnica para atender, sobretudo, alguns setores da economia (ver tabela 5). 52 Aqui cabe ressaltar a análise feita por Joaquim José Soares Neto; Girlene Ribeiro de Jesus; Camila
Akemi Karino e Dalton Francisco de Andrade no artigo intitulado "Uma escala para medir a
infraestrutura escolar". Onde os autores apresentam uma escala de infraestrutura escolar
estabelecidas em quatro categorias: Elementar, Básica, Adequada e Avançada e que foi construída
utilizando como ferramenta a Teoria de Resposta ao Item e baseando-se em informações referentes
às escolas obtidas no Censo Escolar da Educação Básica 2011. A análise aponta que Apenas 0,6\%
das escolas brasileiras têm infraestrutura próxima da ideal para o ensino, isto é, têm biblioteca,
laboratório de informática, quadra esportiva, laboratório de ciências e dependências adequadas para
atender a estudantes com necessidades básicas. Disponível em:
http://www.fcc.org.br/pesquisa/publicacoes/eae/arquivos/1786/1786.pdf

${ }^{53}$ Segundo o Censo Escolar (2013) e os dados do Tribunal de contas da União - TCU (2012) do total dos 13.000 professores efetivos e ativos no ensino médio estadual tem-se os seguintes dados Déficit de professores com formação específica 637, Professores sem formação específica 969 - total 3.802 .

${ }^{54}$ Criado em 2007, o Índice de Desenvolvimento da Educação Básica - IDEB é medido a cada dois anos e apresentado numa escala de zero a dez calculado a partir de dois componentes: a taxa de rendimento escolar (aprovação) e as médias de desempenho nos exames aplicados pelo Inep. Segundo os dados o ensino médio público estadual cearense ficou com a pontuação de 3.3 no ano de 2013, sendo que a meta desejável é de 6,0, considerada uma média que aponta boa qualidade no ensino.

${ }^{55}$ Segundo dados do IPEA (2010), ainda 55,1\% dos jovens brasileiros de 19 anos não conseguem concluir o ensino médio. Enquanto que $42,6 \%$ dos alunos do $3^{\circ}$ ano do ensino médio estão acima da idade adequada. 
Mapa 7: ESTADO DO CEARÀ: Taxa de analfabetismo na faixa etária de 15 a 24 anos por município. 2010.

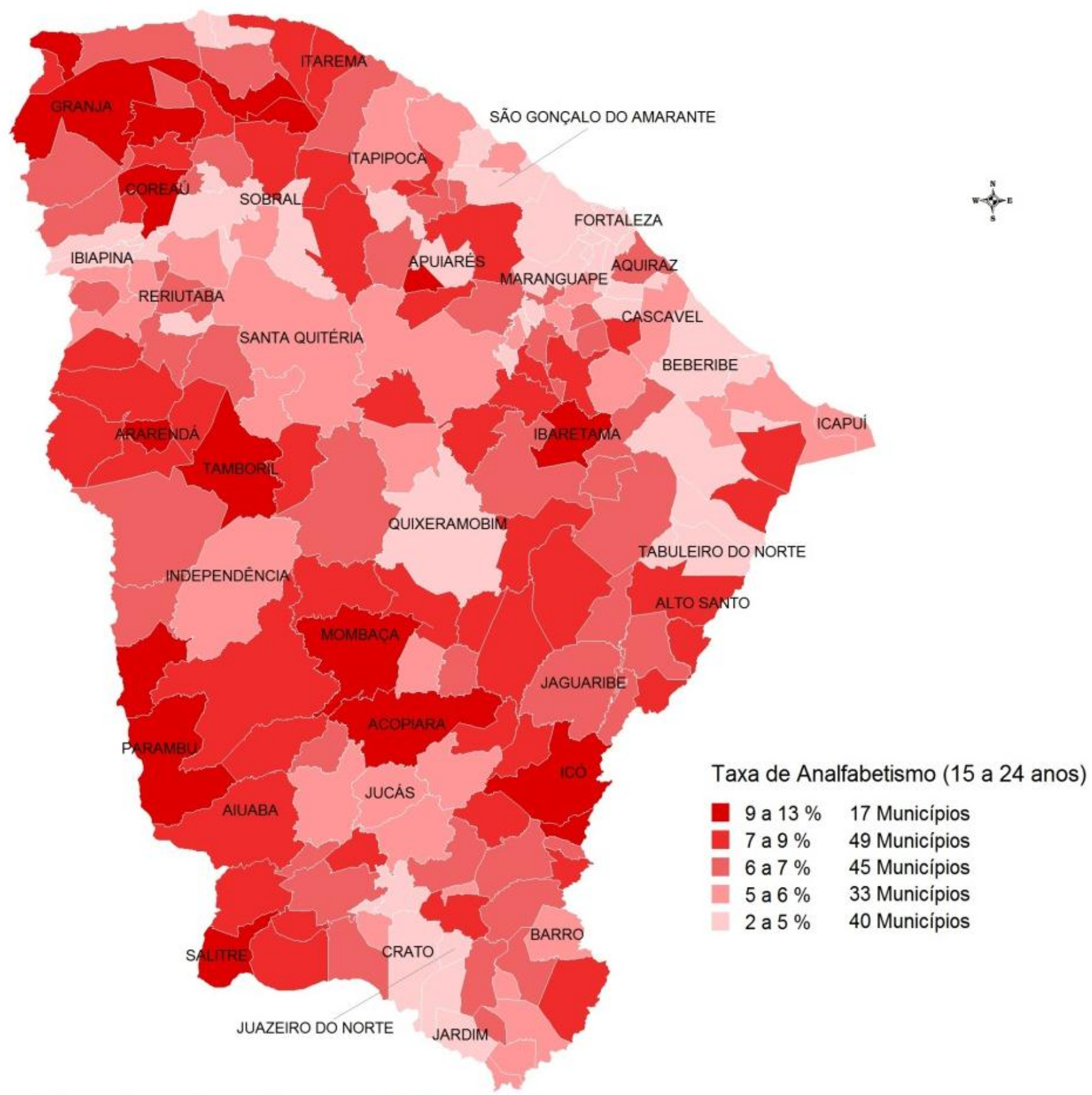

Fonte: Instituto Brasileiro de Geografia e Estatística - IBGE. 2010.

Elaboração Cartográfica: Markelly Fonseca de Araújo. Software Maplnfo Professional. 
Tabela 5: Investimentos nas EEEPs

\begin{tabular}{|c|c|c|c|c|c|c|}
\hline ANO & Obras & $\begin{array}{c}\text { Equipamento e } \\
\text { Material } \\
\text { Permanente }\end{array}$ & Veículos & $\begin{array}{c}\text { Contratação } \\
\text { Professores } \\
\text { Área Técnica }\end{array}$ & Bolsa estágio & $\begin{array}{c}\text { Outros } \\
\text { Investimento } \\
\mathrm{s}\end{array}$ \\
\hline 2008 & $2.734 .025,15$ & 0,0 & 0,0 & 0,0 & 0,0 & 0,0 \\
\hline 2009 & $38.007 .544,50$ & $6.269 .554,55$ & 0,0 & $5.615 .800,00$ & 0,0 & $4.324 .581,82$ \\
\hline 2010 & $184.499 .730,12$ & $9.397 .782,03$ & 0,0 & 19.769.387,02 & $5.102 .250,00$ & $5.661 .792,93$ \\
\hline 2011 & $104.492 .647,08$ & $25.664 .938,58$ & 0,0 & $24.564 .978,46$ & $5.599 .362,06$ & $1.483 .443,87$ \\
\hline 2012 & $116.014 .655,74$ & $35.355 .162,78$ & $5.615 .800,00$ & $48.190 .504,72$ & $13.187 .686,70$ & $4.923 .268,92$ \\
\hline 2013 & $66.928 .741,56$ & $5.719 .271,21$ & 0,0 & $58.210 .218,96$ & $19.453 .243,95$ & $3.643 .538,33$ \\
\hline 2014 & $41.617 .061,99$ & 28.996.322,69 & 0,0 & $80.000 .000,00$ & $24.800 .837,69$ & $41.727 .433,11$ \\
\hline Total & $41.617 .061,99$ & $111.403 .031,84$ & $5.615 .800,00$ & $234.876 .332,87$ & $68.143 .380,40$ & $61.764 .058,98$ \\
\hline
\end{tabular}

Fonte: Sistema Integrado de Acompanhamento de Programas (SIAP/webmapp).

O aumento das escolas técnicas profissionais de nível médio parece indicar certa adaptação ao modelo globalizador em consonância com a economia industrial e comercial que se impõe ao setor público, influenciando a própria organização e condução do ensino.

Uma vez que as ações do Governo Estadual, conjuntamente aos agentes que comandam a economia, privilegiam determinados aspectos econômicos, e tem focado em investimentos em infraestrutura, indústria, construção civil e serviços, acarretando a criação e a ampliação do atendimento para estes setores.

As ações com relação à educação se praticam mediante ao atendimento, sobretudo das demandas provenientes desses investimentos, e passa a ofertar cursos para supri-las, seja em instituições públicas, seja na iniciativa privada, em estabelecimentos de educação particulares.

Conforme as tabelas acima, pode-se fazer uma análise sobre os encaminhamentos da educação técnica de nível médio integrado, que vem sendo pensada para o Estado. Como já mencionado, o fato da educação técnica ser resultado do processo dinâmico da totalidade do mundo, esta reflete as ações que se dão intencionalmente por meio dos objetos selecionados para serem postos no território.

Das análises da dinâmica do território cearense, é possível constatar a difusão do capital por meio da incorporação de novos objetos técnicos que asseguram sua eficácia, pois os investimentos voltam-se para esses setores, no quesito educação. 
A partir disso, o território passa a expressar diferentes modos de uso, visto que a educação passa a ser composta por uma variedade de finalidades, seguindo padrões pré-determinados por uma forma de organização política, que visa, em primeiro plano, atender os interesses de uma lógica hegemônica empresarial, deixando em segundo plano, a preocupação com as demandas das localidades e, mais ainda, uma formação humanística.

Nas palavras de Gramsci:

A tendência, hoje, é a de abolir qualquer tipo de escola "desinteressada" (não imediatamente interessada) e "formativa", ou conservar delas tão somente um reduzido exemplar destinado a uma pequena elite de senhores e de mulheres que não devem pensar em se preparar para um futuro profissional, bem como a de difundir cada vez mais as escolas profissionais especializadas, nas quais o destino do aluno e sua futura atividade são predeterminados (GRAMSCI, 1982, p.117-118).

De fato, o exercício do poder do governo estadual e dos agentes hegemônicos da economia que comandam os territórios, com forte influência na educação, acaba por promover diferentes modelos de educação para diferentes classes sociais e, ainda mais, acaba por não resolver o problema do analfabetismo que ainda é um forte entrave no contexto da educação cearense.

Uma consequência destas formas da ação política é o aumento das desigualdades territoriais, reveladas no acesso ao ensino e no modelo de ensino ofertado de diferentes formas (regular, integrado, técnico, público, privado, dentre outros). Não é à toa que isso se evidencia no território cearense ${ }^{56}$.

Segundo avaliação da Comissão das Comunidades Europeias (Statistical Offi ce of the European Communities - EUROSTAT), "a mensuração da escolaridade da população jovem de 18 a 24 anos de idade com 11 anos de estudo é considerada essencial para avaliar a eficácia do sistema educacional de um país, bem como a

\footnotetext{
${ }^{56}$ Ver Estudos feitos pelo Laboratório de Estudos da Pobreza (LEP), da Universidade Federal do Ceará e os estudos do Instituto de Estudos e Pesquisa do Ceará (IPECE) que possuem um acervo de artigos e pesquisas sobre a pobreza e desigualdade social no Brasil, com preocupações especiais nos problemas do Nordeste e Ceará. Cita-se os estudos de Carlos Manso "A QUEM SE DESTINA O PLANO "BRASIL SEM MISÉRIA"?: perfil dos extremamente pobres no país", o qual observa para o Brasil que, um índice de $8,53 \%$ de seus habitantes vivem abaixo da linha de miséria, determinando um quantitativo de mais de 16,2 milhões de pessoas. Para este total, as maiores participações pertencem aos estados da Bahia (14,80\%), Maranhão (10,40\%) e Ceará $(9,24 \%)$.
} 
capacidade de uma sociedade para combater a pobreza e melhorar a coesão social" (IBGE, 2010).

\begin{abstract}
A taxa de escolarização líquida é um indicador da proporção da população em determinada faixa etária que se encontra frequentando escola no nível adequado à sua idade. Ė analisada pelos quintos do rendimento mensal familiar per capita e, revela fortes desigualdades entre os mais pobres e os mais ricos: no primeiro quinto (os $20 \%$ mais pobres), somente $32,0 \%$ dos adolescentes de 15 a 17 anos de idade estavam no ensino médio, enquanto no último quinto $(20 \%$ mais ricos), essa oportunidade atingia quase $78 \%$ deste grupo, revelando que a renda familiar exerce grande influência na adequação idade/série frequentada (IBGE, 2010).
\end{abstract}

E o que se revela pelas estatísticas, é uma média relativamente baixa de anos de estudo concluídos. Em 2009, o brasileiro de 15 anos ou mais de idade tinha, em média, 7,5 anos de estudo; ou seja, não conseguiu concluir o ciclo fundamental obrigatório, direito adquirido constitucionalmente. Na Região Sudeste, essa média atingiu 8,2 anos, enquanto na Região Nordeste, apenas 6,7, e o no Ceará, essa média é de 5 e 6,5 anos de estudo (IBGE, 2010; IPEA, 2010).

As instituições de educação são cada vez mais adaptadas de acordo com as determinações reprodutivas em mutação do sistema capitalista, o que ocasiona a criação de escolas para diferentes classes sociais; diante disso, se torna difícil democratizar a educação.

Ademais, no território cearense, outros setores poderiam ser alvo de investimentos em formações profissionais. Resta saber como essa situação poderia ser invertida, ou como o governo estadual poderia gerir o uso do território de modo que pudesse realizar os fins que são de sua competência, ou seja, priorizar o bem comum e fortalecer as horizontalidades.

De acordo com dados coletados em campo, muitas cidades que receberam uma escola técnica de tempo integral, ou seja, as zonas opacas, não tem estrutura para acolher os novos técnicos que saem dessas escolas; o que acarreta uma fuga da localidade para as zonas mais densas em técnica e oferta de emprego, ocasionando uma concentração demográfica na capital e nos centros urbanos.

Sendo assim, os altos investimentos nesse modelo de educação poderiam contribuir para a adequação das escolas já existentes ou, quem sabe, pudesse se pensar em ofertar cursos que estivessem mais voltados à realidade das localidades, ou proporcionar uma nova perspectiva para estas. 
Portanto, necessário se faz a análise das políticas voltadas ao ensino técnico de nível médio no Ceará, de forma que este possa contribuir para a reflexão dos projetos futuros para a educação, tais como levantamentos das demandas locais, custo-benefício das escolas em determinados locais, cursos que podem ser viáveis, dentre outros.

Ressalta-se aqui, que não se critica o fato de um estado optar pelo ensino técnico; até porque o território é totalidade e as demandas para setores profissionais existem e devem ser atendidas, mas, desde que algumas condições básicas da educação estejam mais bem atendidas, e desde que se ponha as pessoas em primeiro lugar, ao invés das firmas, empresas e dinheiro.

Enfatiza-se, também, que necessário se faz o desenvolvimento de estudos para verificar até que ponto essas escolas são viáveis em determinadas localidades, e se o são: que cursos poderiam beneficiar realmente a população local? 
CAPÍTULO 4

GLOBALIZAÇÃO, MEIO-TÉCNICO-CIENTÍFICO-INFORMACIONAL E AS NOVAS DEMANDAS EDUCACIONAIS.

Esse capítulo pretende fomentar uma discussão sobre o uso do território, a partir dos processos de desenvolvimento do capitalismo e seus reflexos no espaço geográfico brasileiro. Processos que se acentuaram e intensificaram-se no final do século $X X$, em decorrência da atual fase de expansão do capitalismo, chamada globalização econômica. Nesse contexto, discute-se os usos do território e suas implicações na nova divisão do trabalho especializado; o que implica na formação dos trabalhadores e na refuncionalização da educação para atender as novas demandas oriundas da economia e da sociedade, incorporadas às correntes da globalização. 


\section{Capítulo 4. Globalização, meio-técnico-científico-informacional e as novas demandas educacionais.}

\begin{abstract}
El proceso civilizador del capitalismo puede ser considerado como la historia de la ocupación del mundo, de la globalización del mundo, o de la mundialización de las formas de vivir y organizar el espacio geográfico. Es una manera de organizar la vida, la producción, el trabajo, el consumo, uma forma de civilización que se extendió por todo el mundo y continua haciéndolo por todas las partes de la tierra (LEMOS, 2004, págs. 107-108).
\end{abstract}

As transformações decorrentes do processo de desenvolvimento do capitalismo, impuseram ao espaço geográfico novas formas de relações sociais, novos costumes, novos modelos econômicos e práticas comerciais, como a liberalização financeira, aberturas ao comércio mundial, fragilização dos Estados nacionais, revolução tecnológica e científica, e uma forma de apropriação dos recursos naturais pelos grupos sociais; ocasionando novas formas de pensar e trabalhar o espaço.

O século $X X$ traz com ele as demandas de novas formações de mão-de-obra para o capitalismo, que vai inserindo-se no território. Caminhamos em direção à integração do mercado e, com ele, à interconexão do território.

Suas características são a globalização, ou seja, o conjunto de características que predominam nas relações econômicas, políticas, sociais e culturais a escala mundial que têm suas bases na economia, associada ao modo capitalista de produção e impôs alterações expressivas nas formas de configuração do espaço (CASTELLS, 1999).

No contexto da globalização as principais atividades econômicas se caracterizam pela flexibilização da produção em escala mundial e, consequentemente, pela intensificação dos fluxos de capitais, mercadorias, pessoas e informações, entre os mais diferentes pontos do planeta.

Processos que se acentuaram e intensificaram-se no final do século $X X$, em decorrência da atual fase de expansão do capitalismo. Nesta, o consumo interno dos 
países desenvolvidos, de certo modo, saturou-se, e uma das maneiras de atender ao capital produtivo foi a busca de novos mercados para suprir e ampliar as demandas do capital.

As transformações que ocorriam no espaço geográfico, principalmente, com o advento das novas tecnologias de informação e comunicação, bem como o incremento no fluxo comercial mundial, estreitaram as relações comerciais entre os países e as empresas. As redes de transportes e de computadores permitiram acelerar a circulação de informações e de fluxos financeiros.

A partir das redes de informação e comunicação (telefonia fixa e móvel, computadores, internet, televisão, entre outros) e os fluxos comerciais mundiais, por meio da modernização dos transportes, especialmente o marítimo, foi possível estabelecer um circuito de informações e comunicação entre empresas e instituições financeiras e governamentais, interligando os mercados mundiais.

\section{Os impactos do meio-técnico-científico-informacional nos usos do território cearense pela educação}

O desenvolvimento de tecnologias atreladas aos meios transportes, permitiu maiores trocas, comercialização e a mundialização das mercadorias, promovendo um enorme fluxo de transações comerciais (importação e exportação).

As empresas multinacionais tiveram contribuição fundamental para a efetivação do processo de globalização, pois são essas empresas que atuam em diferentes partes do planeta. Além do mais, elas tiveram forte influência para a criação e formação de blocos econômicos, que buscaram se fortalecer para se tornarem mais competitivas no mercado mundial.

Os territórios passam a ser requalificados de modo a atender, sobretudo, os interesses dos atores hegemônicos da economia e da sociedade, sendo incorporados às correntes da globalização ${ }^{57}$ (SANTOS, 2012). Portanto, a ação dos agentes hegemônicos da economia e da sociedade, por suas possibilidades de

\footnotetext{
57 O processo de Globalização tem suas bases na economia, associada ao modo capitalista de produção e impôs alterações expressivas nas formas de configuração do espaço.
} 
poder econômico e político, asseguram o funcionamento dos processos que se fundem às correntes da globalização. Além disso, os objetos técnicos-informacionais são cada vez mais difundidos, ocasionando uma subordinação às lógicas globais.

As novas tecnologias da informação desempenharam papel decisivo ao facilitarem o surgimento desse capitalismo flexível, proporcionando ferramentas para a formação de redes, comunicação à distância, armazenamento/processamento de informação, individualização coordenada do trabalho, e concentração e descentralização simultâneas do processo decisório. Isso altera os modos de vida das pessoas em todo o mundo, e causa a perda de controle sobre suas próprias vidas, seu meio, seus empregos, suas economias, seus governos, seus países e, em última análise, sobre o destino do planeta (CASTELLS, 1999).

As dissonâncias que marcam esse atual período histórico, trazem consigo uma complexidade maior quanto à condução das políticas territoriais na lógica do fazer, do viver e do usar o território, visto que estas, sobretudo, a serviço das forças hegemônicas e do Estado, são hoje as grandes condutoras das ações que definem as novas realidades espaciais (SANTOS, 2012).

As ações desse período têm forte influência do discurso da racionalidade econômica ${ }^{58}$ e é impregnada por aspectos de modernizações seletivas "inacabadas" ou incompletas.

Essas modernizações atingem vários setores da produção socioeconômica e disseminam-se por outras áreas, chegando até as instituições escolares, influenciando a estrutura organizacional dos currículos do ensino, as relações e formas do trabalho. Logo,

O território ganha novos conteúdos e impõe novos comportamentos, graças a enorme possibilidade de produção e, sobretudo, da circulação dos insumos, dos produtos, do dinheiro, das ideias e informação, das ordens e dos homens (SANTOS \& SILVEIRA, 2000, p. 31).

\footnotetext{
${ }^{58}$ Pode-se dizer que a racionalidade económica responde a dois conceptos: o primeiro, a eleição de objetivos e determinações das finalidades (ideológica) e o outro que se limitaria a determinar os meios para alcançar estas finalidades (ciência). Deste modo parece demostrar-se que a racionalidade económica e a racionalidade da ciência econômica são una mesma questão e que o conhecimento da racionalidade econômica depende das "verdades" e hipóteses elaboradas pelos economistas (e demais especialistas das ciências sociais).
} 
No entanto, esse processo se dá de diversos modos e em diferentes escalas mundial, sendo as nações ricas as mais beneficiadas por meio das ações dos agentes hegemônicos da economia, pois, entre outros fatores, elas expandem seu mercado consumidor por intermédio de suas empresas transnacionais.

Nesse cenário está incluso o Brasil e os seus estados, que recebem a incidência desse meio de diferentes modos, o que define-se como verticalidades. No caso do Ceará, por exemplo, este vem sendo equipado de novos objetos, frutos do meio-técnico-científico-informacional, "elaborados a partir dos mandamentos da ciência e se servem de uma técnica informacional da qual lhes vem o alto coeficiente de intencionalidade com que servem às diversas modalidades e às diversas etapas de produção" (SANTOS, 2012, p. 235).

Nesse sentido, a expansão do mercado e os usos do território, induzem a criação e o desenvolvimento de novas tarefas, novas sequências e especializações. Essa expansão, que é também geográfica, implica nova divisão do trabalho: "especialização de funções, aumento de produtividade, controle do processo de trabalho e, o que é importante também para a compreensão da urbanização, a reposição do trabalhador nesse processo" (SOUZA, 1993, p. 10).

As análises de Corrêa (1997) permitem dizer que, no mundo, intensificam-se e ampliam-se as interações espaciais e, consequentemente, elas tornam-se mais rápidas e mais complexas:

Rompem-se as amarras de horizontes espaciais limitados e
fortemente fechados, submetidos a uma economia
preponderantemente autárquica. Estabelece-se uma crescente
divisão territorial do trabalho que leva a uma necessária articulação
entre áreas e cidades através de uma rede urbana cada vez mais
importante e fortemente articulada (CORREA, 1997, p. 282).

Proudhon apud Ortega y Gasset (1963, p. XXIX), no tocante à divisão do trabalho, exprime que quanto "mais se divide a mão-de-obra, mais aumenta o poder do trabalho, porém, ao mesmo tempo, mais o trabalho se reduz progressivamente a um mecanismo embrutecedor da inteligência", visto que na visão de Proudhon, " as máquinas nos prometiam um aumento de riqueza; e o que recebemos foi um aumento de miséria. Elas nos prometiam a liberdade; eu irei provar que elas nos trouxeram a escravidão". 
Neste aspecto, Santos (1996) esclarece que o componente internacional da divisão do trabalho tende a aumentar exponencialmente no Brasil. Isso impulsiona a aderência de sistemas técnicos muitas vezes estranhos às lógicas locais e mesmo nacionais, pois faz com que o território incorpore os processos de modernizações de forma que a inserção das ideias de cunho liberalizantes se estenda às políticas públicas da educação e se espalhem no território.

Além disso, "os processos de reestruturação do Estado e da economia, sob ideologias liberalizante, postos em curso na década 90, procuraram colocar em prática uma agenda de desenvolvimento sob inspiração de agências e organismos internacionais (FMI, Banco Mundial)" (WINCKLER; SANTAGADA, 2012, p. 100).

Essa agenda englobava também a discussão das políticas para a educação, e estavam assentadas na flexibilização do mercado do trabalho, que exigia uma formação que incorporasse competências e habilidades para além da formação adequada ao modelo taylorista e/ou fordista; ou seja, deveria se adequar à revolução tecnológica, à reestruturação produtiva e às novas exigências das demandas de qualificação.

Referiam-se à emergência de um trabalhador com maior responsabilidade, autonomia, flexibilidade - portador de capacidade de adequação de produção e consumo flexíveis, em um contexto produtivo que reunifica saber e fazer, além de valorizar sua condição subjetiva, singularizada, múltipla - , mas sob a égide do processo de acumulação e/ou mercantilização. Esses novos requerimentos tinham como pressuposto a importância dos conteúdos gerais, a educação permanente em busca da qualidade, a polivalência como ampliação das capacidades laborativas e a ideia de que seria mais relevante no processo pedagógico "aprender a aprender" do que simplesmente receber conteúdos. (WINCKLER; SANTAGADA, 2012, p. 101).

As políticas educacionais focaram-se na tentativa de melhoria do acesso ao ensino obrigatório e sua normatização. A Lei de Diretrizes e Bases da Educação Nacional (LDB), Lei no 9.394/1996, e a Constituição Federal de 1988, dizem que ao Governo Federal cabe estabelecer diretrizes gerais em regime de colaboração com municípios, Distrito Federal e estados, com o apoio da sociedade. Para a efetivação dessa proposta, o Governo Federal instituiu o Fundo de Manutenção e Desenvolvimento do Ensino Fundamental e de Valorização do Magistério (FUNDEF, 1996), instrumento de redistribuição de recursos entre estados e municípios, e 
entendido como essencial à universalização do ensino fundamental (WINCKLER, SANTAGADA, 2007).

Os novos objetos e o avanço progressivo de novas tecnologias permitiram: o aperfeiçoamento dos mecanismos de descentralização dos programas de alimentação escolar, a distribuição de livros escolares, e o repasse direto de recurso às escolas, visando à melhoria da qualidade do ensino e sua oferta.

O ensino médio não era obrigatório, mas se considerava a sua progressiva obrigatoriedade e gratuidade ${ }^{59}$. Vê-se, portanto, que a sua não obrigatoriedade, bem como o fato de não ser de competência direta da União, o deixou relegado a um segundo plano no âmbito do Ministério da Educação (MEC).

Segundo Winckler, Santagada (2009), mesmo com poucos investimentos e a não obrigatoriedade, a partir da década de 1990, houve um crescimento na oferta desse nível de ensino, passando de 3,8 milhões de vagas (1991), para 8,2 milhões (2000). As razões, apontadas "[...] para essa expansão são, em parte, atribuídas à correção do fluxo dos alunos do ensino fundamental, à elevação das suas taxas de promoção e a uma queda na evasão escolar" (p. 67).

Nesse período, também se identifica uma maior influência nas políticas educacionais por parte dos organismos internacionais, onde a política educacional brasileira está atravessada por relações com o Banco Mundial e o FMI, os quais tiveram importante papel na reorientação das políticas públicas nos países do Terceiro Mundo, principalmente na América Latina.

Aqui as relações são perpassadas por exigências mais ou menos de acordo com o Estado, e criam um sistema de normas e progressivamente as impõe, pois a ordem mundial é cada vez mais normativa e condiciona uma "organização" das "coisas" (SANTOS, 2012).

O processo de implantação dessas novas orientações, perpassa a década de 1980 e se desenvolve principalmente na década de 1990, quando se dá o aprofundamento das políticas de abertura comercial, desregulamentações e privatizações iniciadas na década de 1980.

\footnotetext{
${ }^{59}$ ensino fundamental, obrigatório e gratuito, inclusive para os que a ele não tiveram acesso na idade própria..." atendimento em creche e pré-escola às crianças de zero a seis anos de idade...."progressiva extensão da obrigatoriedade e gratuidade ao ensino médio"... "Acesso ao ensino obrigatório e gratuito é direito público subjetivo" (Art. 208 parágrafo primeiro da Constituição da Republica Federativa/1988).
} 
Neste período, são dadas as recomendações para flexibilização do mercado de trabalho, alteração da legislação trabalhista e previdenciária, e a reforma do sistema educacional, com a mercantilização do ensino, que se vincula a aspectos financeiros de fornecimento de empréstimos a países considerados periféricos.

Esses empréstimos tinham como requisitos o cumprimento de condicionalidades, tais como a melhoria da qualidade e da eficácia da educação; a ênfase nos aspectos administrativos e financeiros; a descentralização e autonomia das instituições escolares; a maior participação dos pais e da comunidade nos assuntos escolares; o impulso para o setor privado e organismos nãogovernamentais no terreno educativo; a mobilização e alocação eficaz de recursos adicionais para a educação; um enfoque setorial; a análise econômica como critério dominante na definição das estratégias. (BANCO MUNDIAL, Priorities and Strategies for Education, 1995, p.1-16) ${ }^{60}$.

Assim, com o discurso de combate à pobreza e às desigualdades entre países ricos e pobres, o empréstimo ao país "beneficiado", induz o mesmo a submeter-se às políticas macroeconômicas desses organismos.

Importa dizer que as recomendações desses organismos tiveram notoriedade nos debates da Conferência de Educação para Todos, em Jomtien, na Tailândia em 1990, convocada pela Organização das Nações Unidas para a Educação, a Ciência e a Cultura (UNESCO); Fundo das Nações Unidas para a Infância (UNICEF); Programa das Nações Unidas para o Desenvolvimento (PNUD) e Banco Mundial (Brasil, 1993).

Desta conferência resultaram posições consensuais, sintetizadas na Declaração Mundial de Educação para Todos, as quais estabeleciam diretrizes norteadoras das políticas da educação para vários países do mundo.

No caso do Brasil, as políticas educacionais foram formuladas no contexto dessas diretrizes e resultam disso: leis, documentos e propostas, tais como a Lei de

\footnotetext{
${ }^{60}$ BANCO MUNDIAL. Priorities and strategies for education. The World Banc sector review. Washington, $\quad$ D.C., $1995 . \quad$ Disponível em: $<$ http://siteresources.worldbank.org/EDUCATION/Resources/2782001099079877269/5476641099080118171/Priorities_and_Strategies_for_Ed_WB_Review.pdf>. Acesso em: 30 jun. 2007.
} 
Diretrizes e Bases da Educação Nacional - LDB (Lei no 9.394/1996) e os Parâmetros Curriculares Nacionais - PCN's ${ }^{61}$.

Cita-se também o Fundo de Manutenção e Desenvolvimento do Ensino Fundamental e de Valorização do Magistério (FUNDEF, instituído pela Emenda Constitucional n.ำ 14, de setembro de 1996, e regulamentado pela Lei n.ำ 9.424, de 24 de dezembro do mesmo ano, e pelo Decreto № 2.264, de junho de 1997), que regulamenta o repasse das receitas dos Estados e Municípios para a educação. E a criação, em 1998, do Exame Nacional do Ensino Médio (ENEM), como forma de avaliar os alunos que concluísse a etapa final da educação básica.

Desta forma, as orientações e propostas sugeridas a nível internacional são acatadas e normatizadas no país, evidenciando a influência desses organismos na condução das políticas educacionais.

Nesse aspecto, ZOMIGANNI (2013, p. 63) diz que "os grupos dominantes sempre se utilizam de ideologias (forjadas, por exemplo, por intelectuais engajados), transformadas em "verdades" que são difundidas como sendo válidas para toda sociedade".

Essas ideologias "fatalistas, imobilizantes, que anima o discurso neoliberal, anda solta no mundo, insiste em convencer-nos de que nada podemos contra a realidade" (FREIRE, 1996, p. 19), "tem o poder de se reestruturar a cada crise que ele próprio provoca, nutrindo-se do desenvolvimento desigual e ampliando-se em diferentes escalas, das atividades econômicas específicas à lógica dos diferentes territórios" (ALMEIDA, 2014, p.514).

Por isso, tais ideologias ganham formas e conteúdos pela presença da ação e se efetiva por meio dos objetos, num movimento dirigido à sua espacialização, em que o meio-técnico-cientifico-informacional se efetiva em políticas e objetos que são instrumentalizados pela sociedade, aumentando exponencialmente o componente da divisão internacional do trabalho. Nesse contexto, Santos nos diz que "esse meio tende a ser universal e mesmo onde se manifesta pontualmente, ele assegura o funcionamento dos processos encadeados a que se está chamando de globalização" (SANTOS, 2012, p. 240).

\footnotetext{
${ }^{61} \mathrm{O}$ documento apresenta em seu texto orientações e discussões acerca da educação em âmbito nacional sem caráter de obrigatoriedade os PCNs são um referencial comum para a educação escolar no Brasil e que "cumprem o duplo papel de difundir os princípios da reforma curricular e orientar o professor, na busca de novas abordagens e metodologias" (Brasil, 1999, p. 13).
} 
Assim, a educação como parte da totalidade da dinâmica espacial, adequa seus fins e objetivos, de modo a responder às demandas criadas pela transformação e produção do espaço, com a criação de escolas e cursos que venham a formar pessoas para responder os requisitos desse meio por intermédio de reformas, programas e projetos.

No que se refere à reforma do ensino médio desse período, a mesma entrou em vigor em 1999 e buscou atender aos alunos egressos do ensino fundamental e aos jovens adultos que optassem por continuar os seus estudos.

Com o decreto DECRETO № 2.208, DE 17 DE ABRIL DE 1997, o ensino profissional técnico de nível médio foi separado do ensino médio regular. Ficando a educação profissional objetivada a:

\begin{abstract}
promover a transição entre a escola e o mundo do trabalho; proporcionar a formação de profissionais, aptos a exercerem atividades específicas no trabalho; especializar, aperfeiçoar e atualizar o trabalhador em seus conhecimentos tecnológicos; qualificar, reprofissionalizar e atualizar jovens e adultos trabalhadores, com qualquer nível de escolaridade, visando a sua inserção e melhor desempenho no exercício do trabalho (BRASIL, 1997).
\end{abstract}

Esse decreto se vincula às novas demandas e necessidades produtivas, que induzem a uma nova divisão social e territorial do trabalho, e que criam paralelamente novas profissões, sobretudo, a partir das tecnologias de informação e comunicação.

Portanto, a educação profissional de nível básico se destina "a proporcionar ao cidadão trabalhador conhecimentos que the permitam reprofissionalizar-se, qualificar-se e atualizar-se para o exercício de funções demandadas pelo mundo do trabalho, compatíveis com a complexidade tecnológica do trabalho" (Art 4은 DECRETO № 2.208, DE 17 DE ABRIL DE 1997).

Autores como FRIGOTTO, 1996; SAVIANI, 2000, KUENZER, 2001, dentre outros, em seus estudos, discutiram a separação do Ensino Médio do Ensino Técnico, alertando para o problema da sua dualidade. Assim, enfatizavam que as ações afetavam e limitavam a perspectiva de elevação da escolaridade em alguns casos.

Moraes nos diz que o Decreto n 2.208 de 17 de Abril de 1997, desconstrói o currículo da chamada formação geral, deixando de lado a construção da educação 
integral, que os educadores propunham fazer avançar através da configuração da escola básica unitária (MORAES, 1998, p. 112).

A seu ver, a proposta se baseia numa orientação conservadora da política educacional brasileira que se explicita na análise dos pressupostos que organizam sua apreensão do mundo económico e do mundo politico, ou seja, o ensino técnico deve propiciar competências, que Incorporam 0 saber técnico e outros conhecimentos e habilidades comportamentais necessárias ao desempenho do trabalho participativo (e criativo) na moderna produção. "Redefine-se o conceito tradicional de formação profissional, que passa a ser identificada com escolaridade básica, entendida como pré-requisito indispensável à capacitação específica posterior". (MORAES, 1998, p. 115).

Em termos conceituais, os discursos governamental e empresarial partem do pressuposto de que o processo de restruturação produtiva significa a superação do paradigma taylorista fordista pelo da automação flexível, com decorrências na qualificação e educação da força de trabalho.

Tal leitura do processo de reestruturação produtiva auxilia a compreender a atuação do empresariado brasileiro que, apesar do discurso recorrente, ainda é pouco susceptível - em relação a seus congêneres dos países do capitalismo avançado - a investir na educação profissional. Além disso, torna possível perceber porque o governo (inclusive seu representante máximo, o Presidente da República, em pronunciamento público), naturaliza o mercado e o quadro de exclusão social produzido pelo desemprego estrutural e tecnológico, responsabilizando o trabalhador pela sua empregabilidade e transformando a educação na grande panaceia que resolverá o problema do desemprego. Contudo, se no plano do discurso, governo e empresários insistem em apresentar a educação como "remédio para os males da sociedade", as políticas educacionais atestam o contrário. Longe de implementar ações que minimizem a desigualdade social e superem a exclusão social, as ações empresariais e governamentais destinam-se a garantir "a inclusão dos incluídos". (MORAES, 1998, p. 116).

Nesse contexto, pode-se referir também ao Plano Nacional de Educação PNE (Lei № 10.172, de 09.01.2001), documento resultante dos acordos firmados ainda na Conferência de Jontien (1990), bem como, posteriormente, na Conferência de Dacar (2000) e na Reunião de Ministros da Educação da América Latina e Caribe (2001). O PNE é nomeado também como um Plano de Estado ou pacto para a melhoria da qualidade e democratização da educação (PLANO NACIONAL DE EDUCAÇÃO, 2001). 
Dentre os objetivos e metas do PNE estavam: a expansão gradual do número de escolas públicas de ensino médio, a melhoria da infraestrutura, o oferecimento de vagas para o ensino médio, no prazo de cinco anos, que correspondessem a $50 \%$ e, em 10 anos, a $100 \%$ da demanda.

Isso decorre das novas necessidades produtivas que se criam a partir da renovada dinâmica espacial, agregadora de novos objetos que acresce ao território usado uma diversificação de profissões, as quais sugerem à educação ampliar seu leque de oferta e agregar, ao conteúdo e à organização do ensino, novas aptidões e conhecimentos.

Nas palavras de Santos e Silveira (2008, p. 109), "o país busca tornar-se viável ao enraizamento dos grandes capitais" e se esforçam para adaptar-se às condições de regulação da economia e do território, reequipando algumas áreas (SANTOS; SILVEIRA, 2008).

Nesses termos, foram dadas autorizações em demasia e sem maiores controles para a oferta de cursos profissionalizantes pontuais de caráter privado, destinados às necessidades imediatas do mercado e promovendo a estagnação deliberada de investimentos na rede de ensino profissional federal (WINCKLER; SANTAGADA, 2012).

O Censo da Educação Profissional, realizado em 1999, apontava 3.948 instituições que ofereciam cursos de educação profissional de acordo com a Lei n.ำ 9.394/96 e o Decreto n. 2.208/99. A maioria dos estabelecimentos era de caráter privado $(67 \%)$ e, entre os públicos, destacavam-se os estabelecimentos estaduais (20\%). A rede municipal era responsável por $9 \%$ dos estabelecimentos, e a federal, por 4\% (OEI - MINISTÉRIO DA EDUCAÇÃO DE BRASIL, 1999).

As mudanças no ensino profissional, de certo modo, dá continuidade, ao modelo anterior, ao atender necessidades pontuais e imediatas do mundo do trabalho, além de incorporar a polivalência do trabalhador na aplicação de novas tecnologias.

Com relação ao ensino médio regular, esse encaminhou-se para o processo de adequação aos novos parâmetros das novas demandas do mercado. Embora tenha havido, na sua composição curricular, avanços consideráveis no processo de ensino/aprendizagem; considerando que muitos debates foram travados e muitas sugestões acatadas. 
Os avanços, nesse sentido, foram normatizados pelo Decreto 5.154 de 23 de Julho de 2004 - Art. 4º no qual consta que a educação técnica de nível médio, nos termos dispostos no $\S 2^{\circ}$ do art. 36, art. 40 e parágrafo único do art. 41 da Lei $n^{0}$ 9.394, de 1996.

Portanto, esta poderia ser desenvolvida de forma articulada com o ensino médio, e dar-se de forma integrada na mesma instituição, contando com matrícula única para alunos que já tenham concluído o ensino fundamental; concomitantemente, oferecida somente a quem já tenha concluído o ensino fundamental ou esteja cursando o ensino médio, na qual a complementaridade entre a educação profissional técnica de nível médio e o ensino médio pressupõe a existência de matrículas distintas para cada curso.

Busca-se "o cumprimento das finalidades estabelecidas para a formação geral e as condições de preparação para o exercício de profissões técnicas" (Decreto 5.154 de 23 de Julho de 2004 - Art. $4^{\circ}-\S 2^{\circ}$ ).

Essas orientações vinculam-se, de certo modo, a uma conjuntura política que permeia os anos de 2003-10, quando a noção de flexibilização, proveniente da acumulação flexível, soma-se a valores de cidadania e inclusão, e vê-se uma articulação na distribuição de renda e expansão do mercado interno, como forma de propiciar o desenvolvimento.

A concepção de público ganha importância, e o Estado assume um maior controle no desenvolvimento do país, a partir de investimentos em diversas áreas, e a partir do Programa de Aceleração do Crescimento (PAC), o que ajuda a manter a economia estimulada.

Parte desses investimentos se dirige ao Nordeste (Tabela 6), e o Ceará vai abrigar grandes obras de infraestrutura e investimentos em vários setores, como os já mencionados no capítulo 3.

O Programa Bolsa Família (PBF) impactou no crescimento do país e principalmente no Nordeste. O Ceará está entre os 5 estados do Brasil que mais recebem recursos desse programa, tendo sido captados uma média de quase 2 bilhões entre 2013 e 2015 (Portal da Transparência/ Governo Federal).

O aumento real do salário mínimo também teve um impacto maior no Nordeste e no Ceará (onde $45 \%$ dos ocupados recebem até um salário mínimo, bem acima da média brasileira, que é de $26 \%$ ) do que no Sudeste (onde esse percentual 
é de apenas 17,6\%), segundo dados da Pesquisa Nacional por Amostra de Domicílios (Pnad) [IBGE (2009)].

Tabela 6: Evolução do rendimento médio das famílias Brasil e Regiões

\begin{tabular}{l|c|c|c}
\hline Regiões & $2000(\mathrm{R} \$)$ & $2010(\mathrm{R} \$)$ & $\begin{array}{c}\text { Taxa de crescimento médio } \\
\text { anual 2010-2000. }\end{array}$ \\
\hline Nordeste & 790,46 & $1.369,51$ & 5,6 \\
\hline Centro-oeste & $1.537,74$ & $2.526,78$ & 5,1 \\
\hline Sul & $1.452,45$ & $2.386,26$ & 5,1 \\
\hline Norte & $1.006,96$ & $1.653,55$ & 5,1 \\
\hline Brasil & $\mathbf{1 . 3 7 2 , 5 1}$ & $\mathbf{2 . 1 2 7 , 3 3}$ & $\mathbf{4 , 5}$ \\
\hline Sudeste & $1.697,23$ & $2.490,95$ & 3,9 \\
\hline
\end{tabular}

Fonte: Elaboração Ceplan, com base nos dados dos censos demográficos 2000 e 2010 do IBGE.

*valores a preços de 2010 , deflacionados pelo INPC.

Esses fatos dinamizaram o comércio formal e informal no Ceará, vários setores da Indústria, como os de alimentos e bebidas, e de bens duráveis, se instalaram ou ampliaram suas produções. Houve o aumento de redes de supermercados e shopping centers.

O Programa Minha Casa Minha Vida, criado com o objetivo de enfrentar o elevado déficit habitacional das famílias de baixa renda e financiado pelo Programa de Aceleração do Crescimento (PAC), também dinamizou a economia cearense, sendo o principal beneficiário dessas iniciativas, o setor da construção civil, que aumentou as taxas de crescimento do emprego formal.

No contexto educacional houve, aumento da demanda para a criação de instituições de ensino básico e superior, tanto na rede pública como na particular. $A$ Constituição Federal de 1988, passou por reformulações, e foi criado o Fundo de Manutenção e Desenvolvimento da Educação Básica e de Valorização dos Profissionais da Educação (FUNDEB), aprovado em dezembro de 2006, em substituição ao Fundo de Manutenção e Desenvolvimento do Ensino Fundamental e de Valorização do Magistério (FUNDEF).

O FUNDEB aperfeiçoa o anterior, incluindo a educação infantil e o ensino médio, a educação de jovens e adultos, as modalidades de ensino especial, além do ensino para indígenas e quilombolas. 
Com a Emenda Constitucional n 53/2006, a subvinculação das receitas dos impostos e transferências dos estados, Distrito Federal e municípios, passaram para de $15 \%$ para $20 \%$, e sua utilização foi ampliada para toda a educação básica, sendo a distribuição dos recursos com base no número de alunos da educação básica, informado no censo escolar do ano anterior, computados os estudantes matriculados nos respectivos âmbitos de atuação prioritária (art. 211 da Constituição Federal). Ou seja, os municípios recebem os recursos do FUNDEB com base no número de alunos da educação infantil e do ensino fundamental, e os estados, com base nos alunos do ensino fundamental e médio (Fundo Nacional do Desenvolvimento da Educação - FNDE, 2012).

Essas iniciativas culminaram com a aprovação do Plano de desenvolvimento da Educação, aprovado pelo então Presidente da República Luiz Inácio Lula da Silva e pelo Ministro da Educação Fernando Haddad em 24 de abril de 2007. O objetivo era melhorar a Educação no País, em todas as suas etapas, em um prazo de quinze anos, priorizando a Educação Básica (Ensino Infantil ao Médio).

Apresentado ao país em 15 de março de 2007, o assim chamado Plano de Desenvolvimento da Educação foi lançado oficialmente em 24 de abril, simultaneamente à promulgação do Decreto n. 6.094, dispondo sobre o "Plano de Metas Compromisso Todos pela Educação", portanto, é um conjunto articulado de ações que abrange a educação básica, educação superior, educação profissional, alfabetização e educação continuada.

O PAC, nesse sentido, foi determinante, pois dinamizou vários setores da economia nacional, no caso da Educação o MEC aproveitou, então, o ensejo e lançou o Índice de Desenvolvimento da Educação Básica (IDEB) ${ }^{62}$, e a ele atrelou as diversas ações que já se encontravam na pauta do Ministério, abrangendo os níveis e as modalidades de ensino, além de medidas de apoio e de infraestrutura (SAVIANI, 2007).

As ações apresentadas como parte do PDE, no que se refere à educação básica, estão contempladas com 17 ações, sendo 12 em caráter global, e cinco

\footnotetext{
62 Ideb é o Índice de Desenvolvimento da Educação Básica, criado em 2007, pelo Instituto Nacional de Estudos e Pesquisas Educacionais Anísio Teixeira (Inep), formulado para medir a qualidade do aprendizado nacional e estabelecer metas para a melhoria do ensino. É calculado a partir dos dados sobre aprovação escolar, obtidos no Censo Escolar realizado todos os anos, e médias de desempenho nas avaliações do Inep, a Prova Brasil (para Idebs de escolas e municípios) e a Saeb (no caso dos Idebs dos estados e nacional) - avaliações aplicadas no $5^{\circ}$ e $9^{\circ}$ ano do Ensino Fundamental e no $3^{\circ}$ ano do Ensino Médio.
} 
específicas aos níveis de ensino. Entre as ações que incidem globalmente sobre a educação básica situam-se o FUNDEB, o Plano de Metas do IDEB $^{63}$, duas ações dirigidas à questão docente (Piso do Magistério e Formação), complementadas pelos programas Transporte Escolar ${ }^{64}$, Luz para Todos (energia elétrica para todas as escolas públicas do Brasil), Saúde nas Escolas (visa à integração e articulação permanente da educação e da saúde), Guias de tecnologias ${ }^{65}$, Censo pela Internet (lançamento de dados do censo escolar feito pela Internet), Mais Educação (ampliação da jornada escolar de crianças e adolescentes), Coleção Educadores ${ }^{66}$ e Inclusão Digital. (SAVIANI, 2007).

No ensino profissionalizante, o PDE previa a construção de novas escolas de educação profissional de ensino médio, com a finalidade de elevar a escolaridade e criar alternativas para que o ensino regular tivesse uma maior aproximação do mercado de trabalho (PDE, 2007).

O Ceará se insere nesse processo com o apoio do Governo Federal, e protagoniza vários projetos. A partir de 2004, o Decreto $\mathrm{n}^{0} 5.154$ retomou a possibilidade de integração entre ensino médio regular e ensino técnico, permanecendo, todavia, as demais formas de educação profissional. Assim, o governo federal propunha um reforço nessa modalidade, atendendo também redes municipais e estaduais.

O ensino médio, a partir da perspectiva dessas políticas federais, procurou priorizar esse nível de ensino, bem como em resgatar o ensino profissional, tendo como alternativa o ensino médio profissional integrado.

${ }^{63}$ A partir da análise dos indicadores do Ideb, o MEC oferece apoio técnico ou financeiro aos municípios com índices insuficientes de qualidade de ensino. O MEC dispõe de recursos adicionais aos do Fundo da Educação Básica (Fundeb) para investir nas ações de melhoria do Ideb. http://portal.mec.gov.br/arquivos/Bk_pde/ideb.html

${ }^{64}$ Caminho da Escola é o programa de transporte escolar para estudantes da educação básica que vivem na zona rural. Com a criação de uma linha de financiamento do Banco Nacional de Desenvolvimento Econômico e Social (BNDES), inicialmente de $\mathrm{R} \$ 300$ milhões para o período de 2007 a 2009, governadores e prefeitos podem adquirir ônibus e microônibus zero quilômetro ou embarcações fluviais para levar os estudantes à escola. O financiamento será de até seis anos, com carência de seis meses e taxa de juros de $4 \%$ ao ano. http://portal.mec.gov.br/arquivos/Bk_pde/transporte.html.

${ }^{65}$ voltado para a elaboração de um guia a fim de orientar gestores na hora de escolher tecnologias capazes de melhorar a qualidade do ensino e do aprendizado. http://portal.mec.gov.br/arquivos/Bk_pde/tecnologias.html

${ }^{66}$ Coleção que reúne 31 autores brasileiros e 30 pensadores estrangeiros que exercem influência sobre a educação nacional para as bibliotecas das escolas públicas e bibliotecas públicas do país e de universidades. http://portal.mec.gov.br/component/tags/tag/34955. 
Conforme a Tabela 7, a educação profissional de nível médio no Brasil apresentou uma importante expansão na oferta de vagas. Houve aumento de 89,2\% no número de matrículas, passando, no período de 2008 a 2014, de 927.978 para 1.784.403 vagas.

Tabela 7: Evolução do número de matrículas na educação profissional por dependência administrativa - Brasil 2008-2014.

\begin{tabular}{l|c|c|c|c|c}
\hline \multirow{2}{*}{ Ano } & \multicolumn{5}{|c}{ Matrículas na educação profissional por dependência administrativa } \\
\cline { 2 - 6 } \multicolumn{1}{c|}{ Total } & Federal & Estadual & Municipal & Privada \\
\hline 2008 & $\mathbf{9 4 2 . 9 1 7}$ & 132.732 & 322.362 & 36.120 & 451.703 \\
\hline 2010 & $\mathbf{1 . 1 7 8 . 5 4 0}$ & 179.433 & 418.157 & 32.265 & 548.685 \\
\hline 2012 & $\mathbf{1 . 3 9 8 . 1 9 3}$ & 224.892 & 505.714 & 31.056 & 636.531 \\
\hline 2014 & $\mathbf{1 . 7 8 4 . 4 0 3}$ & 249.604 & 536.678 & 40.927 & 957.194 \\
\hline$\Delta \% \mathbf{2 0 0 8 / 2 0 1 4}$ & $\mathbf{8 9 , 2}$ & 88,1 & 66,5 & 13,3 & 111,9 \\
\hline
\end{tabular}

Fonte: MEC/INEP

Notas: 1) Não inclui matriculas em turmas de atendimento complementar e atendimento educacional especializado (AEE).

2) Inclui matrículas de Educação Profissional Integrada ao Ensino Médio.

O número de escolas de Educação profissional (concomitante e subsequentemente) passou de 3.374 em 2008 para 5.325 em 2014, apresentando um crescimento de $57,8 \%$, passando de 795.459 para 1.374 .569 vagas (Fonte: MEC/Inep/Deed, 2008-2014).

Atrelados a isso, estão programas que visavam subsidiar a profissionalização dos jovens e trabalhadores, e fomentar e apoiar a expansão da rede física de atendimento da educação profissional e tecnológica, como o Programa Nacional de Acesso ao Ensino Técnico e Emprego (Pronatec) ${ }^{67}$, o qual tem como objetivo expandir, interiorizar e democratizar a oferta de cursos de educação profissional técnica de nível médio presencial e à distância, e de cursos e programas de formação inicial e continuada ou qualificação profissional (BRASIL, 2015), assumindo um caráter de política pública de Estado.

Cinco iniciativas integram as ações do programa:

1) Expansão da Rede Federal de Educação Profissional, Científica e Tecnológica;

${ }^{67}$ O Projeto de Lei Pronatec foi aprovado, na Câmara dos Deputados, em 31 de agosto e, no Senado, em 18 de outubro do corrente ano. A Lei no 12.513, de 26 de outubro de 2011, que cria o Pronatec, foi sancionada pela Presidenta Dilma Rousseff. 
2) A Bolsa-Formação, a qual são ofertados cursos técnicos e cursos de formação inicial e continuada ou qualificação profissional para estudantes matriculados no ensino médio (cursos técnicos concomitantes), para quem concluiu o ensino médio (cursos técnicos subsequentes, por meio do Sisutec) e para estudantes da educação de jovens e adultos e, ainda, cursos de qualificação profissional, utilizando as estruturas já existentes nas redes de educação profissional e tecnológica;

3) Os investimentos também congregam uma rede (Rede e- Tec Brasil) em que são ofertados gratuitamente cursos técnicos e de qualificação profissional, na modalidade à distância. Participam as instituições da Rede Federal de Educação Profissional, Científica e Tecnológica, as unidades de ensino dos Serviços Nacionais de Aprendizagem (SENAI, SENAC, SENAR e SENAT) e as instituições de educação profissional vinculadas aos sistemas estaduais de ensino;

4) Acordos de Gratuidade com os Serviços Nacionais de Aprendizagem, que objetivam ampliar, progressivamente, a aplicação dos recursos do SENAI e do SENAC, recebidos da contribuição compulsória, em cursos técnicos e de qualificação profissional, em vagas gratuitas destinadas a pessoas de baixa renda, com prioridade para estudantes e trabalhadores;

5) E a ampliação da oferta e o fortalecimento da educação profissional integrada ao ensino médio nas redes estaduais; em que o governo federal repassa recursos para as redes de educação profissional dos estados e do Distrito Federal (BRASIL, 2015).

Sobre os investimentos nesse setor, o governo federal realizou convênios junto aos estados e ao Distrito Federal que totalizam cerca de dois bilhões de reais para a construção, reforma e ampliação de escolas estaduais, instalação de laboratórios de apoio aos cursos técnicos e capacitação de docentes e gestores escolares.

De acordo com informações do Ministério da Educação, até o final de 2015, foram construídas, reformadas e ampliadas 342 escolas públicas estaduais, aptas a ofertar cursos técnicos integrados ao ensino médio (BRASIL, 2015).

No Ceará, os números também foram expressivos, a partir do ano de 2008, foi implantada pelo governo estadual, na Educação Básica, uma rede de educação profissional, as chamadas Escolas Estaduais de Educação Profissional (E.E.E.Ps) 
que visava incorporar o ensino em tempo integral (médio com o profissional) (Tabela 8).

Tabela 8: Evolução da Educação Profissional Integrada no Ceará. 2008 à 2016.

\begin{tabular}{c|c|c|c|c} 
Ano & $\begin{array}{c}\text { Escolas em } \\
\text { funcionamento } \\
\text { (№) }\end{array}$ & $\begin{array}{c}\text { Municípios } \\
\text { (No) }\end{array}$ & $\begin{array}{c}\text { Cursos } \\
\text { (No) }\end{array}$ & $\begin{array}{c}\text { Matrícula Inicial } \\
\mathbf{1}^{\mathbf{a}}, \mathbf{2}^{\mathbf{a}} \mathbf{e} \mathbf{3}^{\mathbf{a}} \mathbf{\text { séries }}\end{array}$ \\
\hline 2008 & 25 & 20 & 4 & 4.181 \\
\hline 2009 & 51 & 39 & 13 & 11.579 \\
\hline 2010 & 59 & 42 & 18 & 18.677 \\
\hline 2011 & 77 & 57 & 43 & 23.370 \\
\hline 2012 & 92 & 71 & 51 & 28.715 \\
\hline 2013 & 97 & 74 & 51 & 35.928 \\
\hline 2014 & 106 & 82 & 53 & 39.765 \\
\hline 2015 & 111 & 88 & 52 & 43.280 \\
\hline 2016 & 115 & 90 & 53 & 48.198
\end{tabular}

Fonte: Secretaria de Educação do Ceará/ Coordenadoria de Educação Profissional/ Sistema de Gestão Escolar, 2017.

Vê-se na tabela 8 que, entre os anos de 2008 a 2016, foram construídas 115 E.E.E.Ps, sendo os investimentos provenientes de recursos do Programa "Brasil Profissionalizado" e do Tesouro Estadual (BRASIL, MEC, 2013).

Os números de matrículas também são bastante expressivos, e representam o crescente interesse na qualificação do ensino básico e de preparo mais direto para o mercado de trabalho, como foco das políticas da educação profissionalizante, pois, visa, sobretudo, atender às demandas de setores que carecem de mão de obra técnica.

Tabela 9: Oferta de matrículas nas EEEPs no Ceará. 2008 a 2016.

\begin{tabular}{l|l|l|l|l|l|l|l|l|l} 
SÉRIE/ANO & $\mathbf{2 0 0 8}$ & $\mathbf{2 0 0 9}$ & $\mathbf{2 0 1 0}$ & $\mathbf{2 0 1 1}$ & $\mathbf{2 0 1 2}$ & $\mathbf{2 0 1 3}$ & $\mathbf{2 0 1 4}$ & $\mathbf{2 0 1 5}$ & $\mathbf{2 0 1 6}$ \\
\hline $\mathbf{1}^{\circ}$ ano & 4.181 & 7.722 & 7.727 & 10.670 & 13.164 & 14.266 & 15.642 & 17.209 & 18.187 \\
\hline $\mathbf{2}^{\circ}$ ano & & 3.857 & 7.308 & 6.652 & 12.361 & 12.361 & 12.606 & 14.105 & 16.288 \\
\hline 3 ano- & & & 3.642 & 6.175 & 6.031 & 9.301 & 11.517 & 11.966 & 13.723 \\
\hline Total & 4.181 & 11.579 & 18.677 & 23.370 & 28.715 & 35.928 & 39.765 & 43.280 & 48.198
\end{tabular}

Fonte: Secretaria de Educação do Ceará/ Coordenadoria de Educação/ Sistema de Gestão Escolar - Data-base Censo Escolar. 
Como se buscou explicitar, a maior expansão desta rede material acontece pelo fato de as instituições de educação, na avidez da reprodução ampliada do capital, verem, no setor educacional, mais uma maneira de adequá-las no sentido de responder ao mercado, no que se refere ao atendimento das novas demandas provenientes dos modos de produção capitalista.

Nesse quesito, as verticalidades superpõem-se à autonomia das decisões desses países, no âmbito da condução da educação, o que resulta numa orientação guiada para atender as demandas provenientes do sistema econômico no qual esses organismos são procedentes. O que não quer dizer que isso seja totalmente acatado, pois cada território tem suas particularidades, e seu uso também se dá pelas horizontalidades expressas na vida dos diversos agentes, e também guiam as políticas de educação. Porém, sua força de incidência não é tão eficaz quanto as verticais.

As EEEPs são um exemplo claro da eficácia das verticalidades, uma vez que a força do mercado incide no território, e estas surgem como forma de atender a essa dinâmica com a oferta cursos para suprir tais exigências.

Bernardes (1999) apud Amorim (2010 p.156) elucida, no que concerne às necessidades de qualificação da força de trabalho, que na atual etapa de desenvolvimento das forças produtivas, a especificidade do trabalho consiste na inserção de pessoal de nível técnico e científico em maior proporção. Ou seja, fundamenta-se na necessidade de ter acesso a um mercado de trabalho mais qualificado, apontando que "a dinâmica das modernizações é mais a de exclusão do que a de integração".

Isso porque, como defendido, no atual período histórico, a ampliação do ensino técnico profissional exprime a lógica do atendimento às demandas do mercado global mais do que às demandas locais.

A cada dia, assiste-se uma especialização da mão-de-obra ou uma busca por novas capacitações, motivadas quer seja pela exigência do mercado de trabalho, quer seja pelos discursos de ampliação do mercado, fazendo com que o território responda a tudo isso por meio da oferta do ensino técnico profissional.

Neste sentido, o ensino e o trabalho passaram a estar ligados ao tempo rítmico da globalização que se reflete em mudanças ocorridas no espaço geográfico [...] Este meio é constituído por sistema de ação, por técnicas e por objetos orientados por ideários e pela 
racionalidade dominante que alteram as relações entre cultura e economia e entre cultura e novas tecnologias. No processo produtivo altera-se a organização do trabalho, sobretudo no que se refere às questões entre saber e fazer. Assim, no campo da qualificação do trabalho, estas mudanças têm forçado a imposição de um novo perfil de trabalhador (SILVA, 1999, p. 304-305).

As transformações das bases materiais e sociais do território brasileiro, graças aos acréscimos de ciência e técnica, explicitam, dessa forma, o aparecimento de novas qualificações profissionais (SILVEIRA, 2005).

Ao Estado cabe a tarefa de atender a essas demandas dando subsídios e suportes nos mais variados setores, assim, adquirem uma nova lógica de operação, em que seu poder é limitado frente à expansão das verticalidades, o que acaba por torná-lo um contribuinte e/ou financiador da lógica econômica hegemônica.

Os organismos oficiais, em conjunto com a inciativa privada, outra característica da sociedade globalizada, estão trabalhando para remodelar o território a partir dessa ordem, com as grandes instalações de equipamentos que a alta tecnologia da informação exige (LEMOS, 2004, p. 119).

Como resultante da capacidade em alocar uma série de elementos materiais, bem como uma gama de serviços de suporte para o funcionamento dessa ordem global, concomitantemente à expansão do mercado, as ações planejadas e os novos objetos rearranjam o território cearense, e the imprime transformações e mudanças socioespaciais que se refletem em diferentes setores e escalas no contexto das relações sociais, fazendo com que as conexões entre os lugares se deem em ritmo cada vez mais intenso, e estimulando as mais diferentes formas de convivência social desigual. 


\section{PARTE III}

AÇÕES E NORMATIZAÇÕES PARA A EDUCAÇÃO TÉCNICA PROFISSIONAL DE NÍVEL MÉDIO INTEGRADA E O USO DO TERRITÓRIO CEARENSE: AS CONTRADIÇÕES ENTRE O ATO DE PRODUZIR E VIVER E OUTRAS POSSIBILIDADES. 
Foto 8: EEEP Guiomar Belchuior Aguiar - Cariré/CE

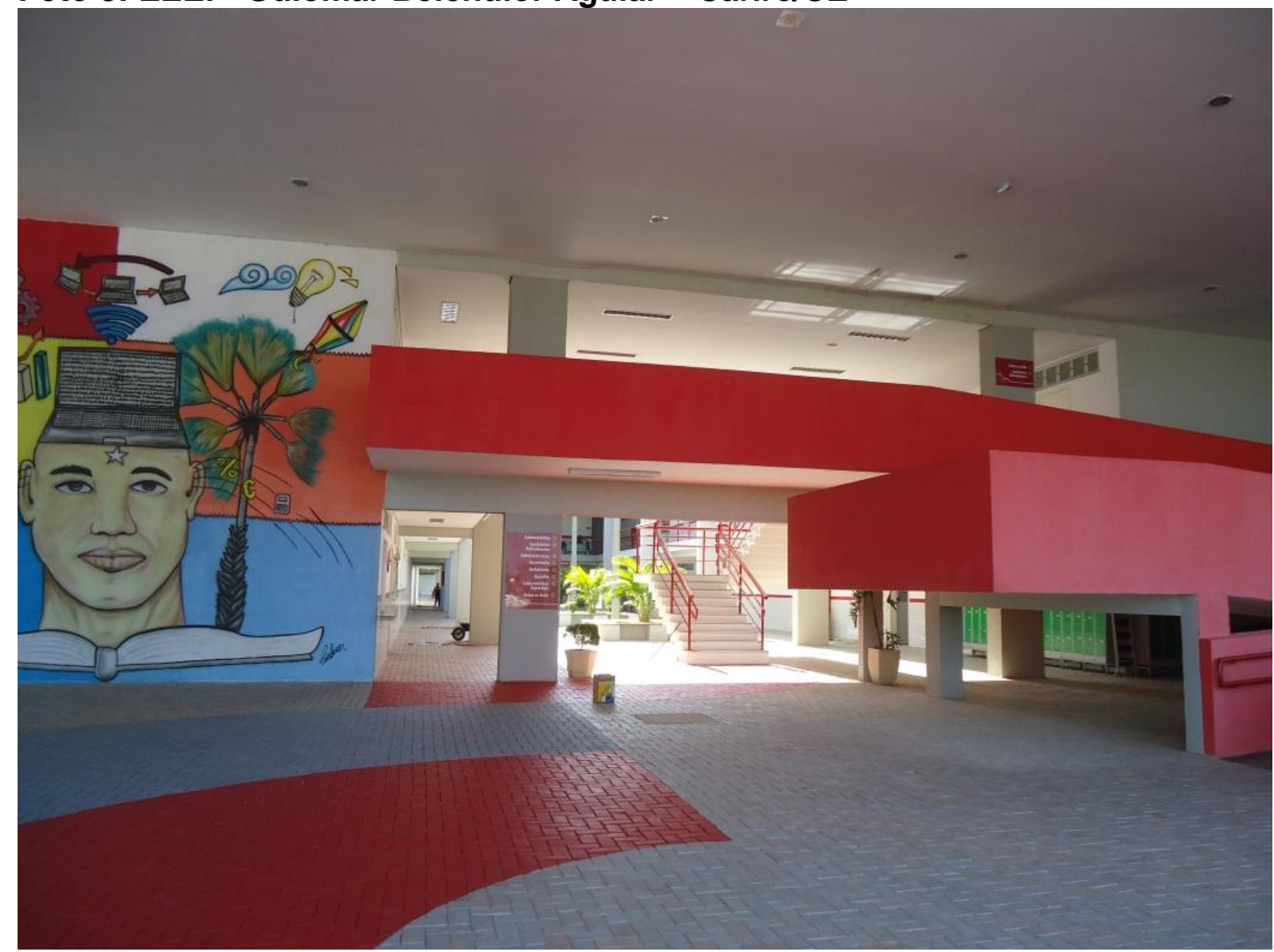

Fonte: Moraes, 2016.

Nesta parte, discutem-se as políticas voltadas para a Educação Técnica Profissional de Nível Médio Integrada ao Ensino Médio, analisando o projeto que vem se constituindo no contexto social cearense, o qual vincula-se ao processo de evolução e transformação da sociedade e a sua organização política territorial. Questiona-se: As normas estão de acordo com a realidade das localidades ou essas se sobressaem para atender a hegemonia do mercado? Discute-se as leis e normas no intuito de buscar entender as motivações das ações que normatizaram as políticas para a educação básica nessa modalidade. 


\section{CAPÍTULO 5}

\section{ESTADO, AÇÕES E NORMATIZAÇÕES PARA A EDUCAÇÃO TÉCNICA PROFISSIONAL INTEGRADA AO ENSINO MÉDIO}

Neste capítulo, serão discutidos as leis e normatizações no contexto do uso do território pela EEEPs. Assim, busca-se analisar o processo, as políticas e determinações que induziram a opção por essa modalidade de ensino e a implantação dessas escolas. 


\title{
Capítulo 5. Estado, ações e normatizações para a Educação Técnica Profissional Integrada ao Ensino Médio.
}

\begin{abstract}
A ordem global busca impor, a todos os lugares, uma única racionalidade. $\mathrm{E}$ os lugares respondem ao Mundo segundo os diversos modos de sua própria racionalidade. (Milton Santos, A natureza do espaço)
\end{abstract}

A normatização da educação técnica de nível médio integrada, ocorreu inicialmente em 2003, na ocasião de dois Seminários: O Seminário Nacional "Ensino Médio: Construção Política”, que ocorreu em Brasília em maio de 2003, e o segundo, o Seminário Nacional de Educação Profissional "Concepções, experiências, problemas e propostas", que foi o marco da discussão da integração. Ambos foram organizados pelo Ministério da Educação/SEMTEC e tiveram como objetivo discutir a realidade do ensino médio brasileiro e as novas perspectivas na construção de uma política para esse nível de ensino.

Vale ressaltar que nesses seminários, principalmente no segundo, "ficou evidenciado duas concepções de educação profissional, a primeira ancorada nos princípios do Decreto no. 2.208/97, que na sua essência separava a educação profissional da educação básica, e outra que trazia para o debate os princípios da educação tecnológica/politecnia" (BRASIL, 2007, p. 6).

Segundo o MEC, a princípio a discussão sobre as finalidades do ensino médio buscava superar a determinação histórica do mercado de trabalho sobre essa etapa de ensino, também discutia a superação da dualidade entre formação específica e formação geral, deslocando o foco dos seus objetivos do mercado de trabalho para a pessoa humana, tendo como dimensões indissociáveis o trabalho, a ciência, a cultura e a tecnologia. O desafio era "elaborar uma política que superasse essa dicotomia entre conhecimentos específicos e gerais, entre ensino médio e educação profissional" (BRASIL, 2007, p. 7).

Assim, já havia indícios naquele momento "da perspectiva de integração das políticas para o ensino médio e para a educação profissional, tendo como objetivo o aumento da escolarização e a melhoria da qualidade da formação do jovem e adulto trabalhador" (BRASIL, 2007, p. 10). 
A SEMTEC/MEC propôs a elaboração de uma política que pudesse congregar a base curricular regular adotada no ensino médio e a educação profissional.

Alguns entraves para a proposta foram debatidos, como o que constava no Decreto no. 2.208/97, que coibia a possibilidade da integração da formação básica e profissional de forma orgânica num mesmo currículo.

A mudança na legislação, em discussão, desde a origem do Decreto №. 2.208/97, propunha distinções entre a formação no ensino básico e o profissional (BRASIL, 1997).

A resposta a essa questão foi à proposição de uma nova regulamentação, o Decreto no. 5.154/04. Nesse, consta em seu Art. 4ํㅜ, que a educação profissional técnica de nível médio, nos termos dispostos no $\S 2^{\circ}$ do art. 36 , art. 40 e parágrafo único do art. 41 da Lei $n^{0} 9.394$, de 1996, seria desenvolvida de forma articulada com o ensino médio.

Essa articulação seria de forma:

I - integrada, oferecida somente a quem já tenha concluído o ensino fundamental, sendo o curso planejado de modo a conduzir o aluno à habilitação profissional técnica de nível médio, na mesma instituição de ensino, contando com matrícula única para cada aluno;

II - concomitante, oferecida somente a quem já tenha concluído o ensino fundamental ou esteja cursando o ensino médio, na qual a complementaridade entre a educação profissional técnica de nível médio e o ensino médio pressupõe a existência de matrículas distintas para cada curso, podendo ocorrer:

a) na mesma instituição de ensino, aproveitando-se as oportunidades educacionais disponíveis;

b) em instituições de ensino distintas, aproveitando-se as oportunidades educacionais disponíveis; ou

c) em instituições de ensino distintas, mediante convênios de intercomplementaridade, visando 0 planejamento e 0 desenvolvimento de projetos pedagógicos unificados;

III - subsequente, oferecida somente a quem já tenha concluído o ensino médio. (BRASIL, 2004, p.1).

Igualmente no $\S 2^{\circ}$, na hipótese prevista no inciso I do $\S 1^{\circ}$, a instituição de ensino, observados o inciso I do art. 24 da Lei $n^{\circ}$ 9.394, de 1996, e as diretrizes curriculares nacionais para a educação profissional técnica de nível médio, deverá ampliar a carga horária total do curso, no intuito de assegurar, simultaneamente, o 
cumprimento das finalidades estabelecidas para a formação geral, e as condições de preparação para o exercício de profissões técnicas (BRASIL, 2004, p.1).

Como justificativa o decreto utiliza como argumento que "a educação profissional, integrada às diferentes formas de educação, ao trabalho, à ciência e à tecnologia, conduz ao permanente desenvolvimento de aptidões para a vida produtiva" (artigo 39).

Vê-se, portanto, que o fundamento explicativo do modelo proposto busca a integração da educação profissional com o processo produtivo, com a produção de conhecimentos e com o desenvolvimento científico-tecnológico. O que está no cerne da discussão do uso do território e, como este, atualmente se enquadra no meiotécnico-cientifico-informacional; visto que os objetos técnicos dotados de uma especialização extrema tendem a se dar como sistemas integrados à materialidade do território, e fazem com que outros objetos participem dos sistemas hegemônicos no contexto social.

A evolução técnica ocasiona uma pressão de estímulos, solicitações ocasionais ou permanentes de condições de existência modificadas constantemente pela necessidade incessante do ser humano de agir sobre o meio, que se transforma pelo uso que se faz do território (ORTEGA Y GASSET, 1968).

Por isso, a organização da educação profissional articula o profissional técnico e o ensino regular, uma vez que o território usado é técnico-cientificoinformacional e, portanto, requer preparar o aluno ao exercício de profissões técnicas, mas também, propõe formá-lo para exercer a cidadania e para outras profissões que não requerem aprofundamentos técnicos.

A discussão sobre a superação da determinação histórica do mercado de trabalho sobre essa etapa de ensino, se esvazia, pois como parte integrante dos sistemas de objetos e sistemas de ações, a educação é usada como subsistema técnico hegemonizado, embora se sobressaia como resistência do mesmo, pois, muitas vezes é conduzida por agentes não hegemônicos.

Essa condução visa o alcance de objetivos que buscam um olhar mais aguçado sobre a sociedade e é discutida por parte de um grande número de educadores.

Nesse sentido, há publicações, debates e discursos que visam elucidar a sociedade sobre o risco que se corre ao conduzir a educação ao patamar de formadora de mão de obra para o mercado. 
Contudo, o alcance de tais objetivos não é uma tarefa fácil, considerando que no contexto da organização espacial atual, as normas, nas quais a educação está baseada, seguem uma orientação muito forte da ideologia do mercado, dos organismos internacionais e do próprio contexto espacial estruturado para receber os novos objetos vinculados a uma orientação hegemônica.

Tem-se uma correlação de forças no território usado (SANTOS, 2008), uma vez que são criadas normas, cujo centro de comando não se limita ao nacional, ao contrário, as normas se constituem a partir de um sistema técnico que atualmente impera no planeta. Há uma interação entre diferentes arranjos de objetos técnicos com todas as formas de ações sociais possíveis. Nesse período, estas estão sob o comando de alguns centros, através de subsistemas de objetos técnicos informacionais.

Esses centros de comando usam, a seu favor, o poder que têm para usufruir intensamente das possibilidades e potencialidades de cada território nacional, mesmo que isso interfira no equilíbrio das formações socioespaciais, uma vez que muitos objetos colocados e organizados por normas estranhas ao território, nem sempre trarão benefícios para as pessoas, ao contrário, podem trazer desarranjos no uso do território com consequências graves e, às vezes, de difícil resolução.

A política empreendida por esses centros de comando, segue a política dominante para a condução do sistema capitalista, em que o mercado econômico mundial busca cada vez mais uma acumulação maior de capital. Com isso, os usos do território apresentam uma relação conflituosa, e cabe ao Estado mediar uma solução para isso.

Karel Kosik diz que "tudo é mercado, ou tudo é maquinação". (KOSIK, a nossa crise atual, 1969), porém, há as prerrogativas do Estado, do espaço banal, dos diversos agentes, que usam o território e criam resistências na busca de sobreviverem.

Até porque o espaço é instância onde ocorre a diversificação movida pela produção de objetos geográficos que orientam seu uso e concomitantemente incide na divisão territorial do trabalho, que por sua vez,

supõe a existência de conflitos, dentre os quais alguns são mais relevantes. O primeiro é a disputa entre o Estado e o mercado. Mas não podemos nos referir a essas duas entidades como se fosse um dado maciço. Dentro do mercado, as diversas empresas, segundo a 
sua força, e segundo os respectivos processos produtivos, induzem a uma divisão do trabalho que corresponde ao seu próprio interesse. $\mathrm{E}$ as diversas escalas do poder público também concorrem por uma organização do território adaptada as prerrogativas de cada um. As modalidades de exercício da política do poder público e da política das empresas têm fundamento na divisão territorial do trabalho e buscam modifica-las à sua imagem (SANTOS, 2012, p. 135).

Daí porque se fala de resistências, de espaço banal. O próprio contexto da organização educacional perpassa a existência, a cooperação e a reflexão de diversos agentes; pois a educação ocorre, sobretudo, no lugar, no espaço do acontecer solidário, através de trocas e experiências diversas.

Porém, cabe ao Estado ${ }^{68}$ a condução e organização das instituições de educação, no sentido de organizá-las como um sistema. Como o Estado se organiza a partir da sociedade civil, - isto é, o conjunto de organismos chamados comumente de "privados") e o da "sociedade política ou Estado", que correspondem à função de "hegemonia" que o grupo dominante exerce em toda a sociedade e àquela de domínio direto" ou de comando, que se expressa no Estado e no governo "jurídico", pode, com a mesma, estabelecer relações contraditórias (como o uso do Estado para fins que não são de interesses da maioria que o mantêm) (GRAMSCI, 1984, p. 10-11).

Esta contradição, já mencionada por Gramsci (1984), é dada no próprio funcionamento da sociedade civil e da sociedade política (GRAMSCI, 1984). Pois se trata de um

\begin{abstract}
"consenso" espontâneo" dado pelas grandes massas da população à orientação impressa pelo grupo fundamental dominante à vida social, consenso que nasce "historicamente" do prestígio (e, portanto, da confiança) que o grupo dominante obtém, por causa de sua posição e de sua função no mundo da produção; 2) do aparato de coerção estatal que assegura "legalmente" a disciplina dos grupos que não "consentem", nem ativa nem passivamente, mas que é constituído para toda a sociedade, na previsão dos momentos de crise no comando e na direção, nos quais fracassa o consenso espontâneo. (Gramsci, 1984, p.11)
\end{abstract}

\footnotetext{
${ }^{68} \mathrm{O}$ Estado, entendido como o conjunto de instituições permanentes - como órgãos legislativos, tribunais, exército e outras que não formam um bloco monolítico necessariamente - que possibilitam a ação do governo; e Governo, como o conjunto de programas e projetos que parte da sociedade (políticos, técnicos, organismos da sociedade civil e outros) propõe para a sociedade como um todo, configurando-se a orientação política de um determinado governo que assume e desempenha as funções de Estado por um determinado período.
} 
Portanto, as forças e/ou organizações hegemônicas ${ }^{69}$ buscam um consenso, por meio do qual possam controlar a vida social e efetivar seus interesses através do consentimento em torno do que parece ser interesse de todos, no que diz respeito às normas adotadas.

Em um trecho Gramsci elucida que

os empresários -- se não todos, pelo menos uma elite deles -- devem possuir a capacidade de organizar a sociedade em geral, em todo o seu complexo organismo de serviços, inclusive no organismo estatal, em vista da necessidade de criar as condições mais favoráveis à expansão da própria classe: ou, pelo menos, devem possuir a capacidade de escolher os "prepostos" (empregados especializados) a quem confiar esta atividade organizativa das relações gerais exteriores a fábrica. Pode-se observar que os intelectuais "orgánicos", que cada nova classe cria consigo e elabora em seu desenvolvimento progressivo, são, no mais das vezes, "especializações" de aspectos parciais da atividade primitiva do tipo social novo que a nova classe deu à luz (GRAMSCI, 1984, p. 4).

Essa reflexão gramsciana é válida para uma análise crítica da educação técnica, pois ela é útil, na maior parte, para atender uma hegemonia de mercado, em detrimento de uma maioria menos privilegiada política e economicamente, justamente aquela que deveria ser potencialmente atendida pelo Estado.

Isso ocorre porque o Estado, hoje, através de suas ações e políticas, toma decisões influenciadas por redes transnacionais intergovernamentais. Como consequência, o papel do Estado transforma-se num crescente instrumento de adaptação das políticas nacionais à realidade internacional e, portanto, de decisões tomadas em outras esferas de poder, sejam elas regionais, transnacionais ou internacionais (HERZ, 1999).

A legitimidade do Estado, e o poder a ele atribuído para amparar e fazer garantir os interesses da maioria, é diminuído porque a "(...) expansão das forças transnacionais reduz o controle que cada governo pode exercer sobre as atividades de seus cidadãos e dos outros povos" (HELD; MCGREW, 2001: 34-35).

A interdependência crescente, no tempo presente, se superpõe à legitimidade e a soberania dos lugares, pois busca o controle da capacidade do

${ }^{69}$ Corporações hegemônicas definidas como organizações transnacionais que controlam os usos do território por meio de sistemas técnicos mundializados, impondo normas e padrões estranhos ao lugar, fragmentando e desfigurando o território. 
Estado na oferta de bens e serviços às suas populações, sem levar em consideração a cooperação internacional.

É no domínio do consenso, da "necessidade" de enquadramento aos mandamentos do mercado, de uma nova lex mercatoria ${ }^{70}$, que a educação é induzida a adequar suas normas aos moldes da produção capitalista, admitindo essa, como uma evolução natural da própria sociedade, e se voltando cada vez mais ao atendimento das relações de reprodução do capital.

No Ceará, isso se traduz mediante os esforços empreendidos em angariar capital externo para o território, porém a custo alto por parte do Estado. Um exemplo é o Complexo Portuário do Pecém, que tem sido alvo de grandes investimentos para receber novos aparatos tecnológicos provenientes do meio-técnico-científicoinformacional, onde empresas estrangeiras superpõem-se, trazendo para o território novos usos, esses muitas vezes dissociados da realidade local.

Essas modernizações sucessivas das atividades econômicas e dos grandes investimentos, "processo também fomentado pelo Estado quando promove mecanização ou automatização da produção, diminui o número de empregos formais, mas amplia a concentração de capital e renda" (ZOMIGHANI JUNIOR, 2013, p. 340).

Dentre outras consequências, há um atrofiamento das solidariedades orgânicas que se processavam em torno da produção social das necessidades e na distribuição e consumo das mesmas. Os usos verticais das técnicas induzem à extinção de postos de trabalhos e/ou a criação de outros tipos, que tem por base uma qualificação voltada para atender aos desígnios da produção mundial.

Nesse aspecto, tem-se um desordenamento do mundo do trabalho pela modernização e concentração de capitais fixos que "associada à maior exigência de qualificação, afunila oportunidades, imprimindo um ritmo insano onde a competitividade máxima entre todos é a regra (o que também é uma violência), como constituinte perverso das novas estruturas da sociedade neoliberal" (ZOMIGHANI JUNIOR, 2013, p. 340).

\footnotetext{
70 "Lex mercatoria é um conjunto de princípios e regras costumeiros, espontaneamente referidos ou elaborados no quadro do comércio internacional, sem referência a um sistema particular de lei nacional" (GOLDMAN, 1964 apud FIORAT, 2004, p. 19). A lex mercatoria como ordenamento jurídico autônomo e os Estados em desenvolvimento. Revista de Informação Legislativa. Disponível em: https://www2.senado.leg.br/bdsf/bitstream/handle/id/1004/R164-02. pdf?sequence=4.
} 
Seu poder de influência atinge a educação no sentido de promovê-la para responder aos novos usos, com uma exigência de formação flexível e uma perspectiva que pouco se volta a uma visão mais humanística da realidade.

\section{Espaço banal: o território de todos e a oferta da educação profissional de nível médio}

A educação sofre os efeitos de diferentes interesses expressos nos usos do território. Há a interferência do Estado guiada pela força das verticalidades, em que estão presentes os interesses referentes à acumulação do capital. Mas há também as horizontalidades, as quais se expressam inicialmente pelo uso do espaço banal, seguida pelas reivindicações dos trabalhadores.

Por isso, é equívocado pensar que os objetivos e fins da educação técnica integrada se limitem estritamente à formação dos interesses dos agentes hegemônicos, ou que a educação profissional se restrinja a atender somente ao mercado.

Para OFFE (1984), no contexto da política educacional, e do ponto de vista estratégico, é mais vantajoso "estabelecer um máximo de opções de troca para o capital e para a força de trabalho, de modo a maximizar a probabilidade de que membros de ambas as classes possam ingressar nas relações de produção capitalistas". (OFFE, 1984, p. 128).

Essa seria uma boa explicação para o fato de hoje a educação profissional apresentar tantas diversificações e, no caso do Ceará, buscar a integralidade. Mas, por outro lado, é preciso ressaltar que as ações empreendidas pelo Estado não se implementam automaticamente; ela se dá pelo uso, num movimento contraditório, portanto, podem gerar resultados diferentes dos esperados.

Especialmente por se voltar para, e dizer respeito a, diferentes agentes, o impacto das políticas sociais implementadas pelo Estado sofre o efeito de interesses distintos expressos nas relações sociais de poder. (HÖFLING, 2001, p. 35).

Isso se reflete nas novas dinâmicas territoriais que induzem a constante criação de demandas para atendê-las. 
Um exemplo a ser dado é a quantidade de ofertas de cursos que compõem o Catálogo Nacional de Cursos Técnicos (CNCT) - instituído pela Portaria MEC no 870, de 16 de julho de 2008, com base no Parecer CNE/CEB no 11/2008 e na Resolução CNE/CEB nº 3/2008 -, criado para orientar as instituições que ofertam educação profissional técnica de nível médio a estudantes e à sociedade em geral (BRASIL, MINISTERIO DA EDUCAÇÃO, 2016). Funciona como um referencial para subsidiar o planejamento dos cursos e correspondentes qualificações profissionais e especializações técnicas de nível médio, e é atualizado periodicamente para contemplar novas demandas criadas pelo uso do território.

Com relação às denominações dos cursos, os mesmos apresentam 227 cursos divididos em treze eixos tecnológicos (Anexo 2). Esses cursos estão atrelados às novas demandas que induzem cada vez mais especializações voltadas ao conhecimento técnico-científico, e que tende a responder a essa lógica organizacional em todas as escalas geográficas.

No Ceará, não diferentemente das demais localidades, as novas dinâmicas territoriais são impulsionadas pela intensidade das inovações técnicas-científicasinformacionais, que faz com que se acentuem os fluxos de informação e comercialização de mercadorias, havendo uma retroalimentação no sistema produtivo.

"Cria-se dessa maneira um mecanismo sem o qual o sistema regido pelo mercado sucumbiria [...]" não obstante, cada vez mais se requer a presença de serviços modernos, que dão base aos rearranjos dos territórios que se inserem nas condições exigidas pelo sistema produtivo global (LIMA; VASCONCELOS; FREITAS, 2011, p. 68).

À medida que isso acontece, há uma reorganização dos lugares que são renovados permanentemente pelas formas do agir e pensar, alterando as relações que se dão no uso do território.

As forças hegemônicas que controlam esses mecanismos de indução nas formas de pensar e agir humanas, imprimem no mundo e nos lugares, suas maneiras de ser e viver, configurando no território suas marcas.

Desse modo, conforme os países ou regiões desejem participar desse arcabouço globalizante, eles são, de certo modo, obrigados a inscrever seus projetos no contexto, vinculados às modernizações advindas desse atual período. 
Ribeiro (2005, p. 265) diz que no período atual da globalização, "o mapa do mundo tem sido reconstruído [...] como um único território aberto à ação hegemônica, sem fronteiras e sem barreiras. Trata-se de um extraordinário alargamento do tabuleiro da política, simultâneo à arena da produção".

As EEEPs são uma resultante dos desdobramentos das ações dos "grandes provedores das ideias que guiam a reconstrução ou a remodelação dos espaços nacionais, juntamente com a da economia, da sociedade e, em consequência, da política" (SANTOS \& SILVEIRA, 2000, p. 26).

Essas escolas têm em suas vertentes organizacionais as bases da articulação das conexões mundo-lugar, pois contêm em seus conteúdos uma tentativa de agregar as lógicas do fazer, viver e usar o território, numa perspectiva das localidades. Porém, sua condução acaba por se conectar aos anseios de uma lógica de caráter reprodutivista, que passa pelas normatizações e sistematizações.

Ao analisar a oferta dos cursos, percebe-se que estas normatizações e sistematizações apresentam demandas diferenciadas e variadas, que em sua maioria sinalizam mais a incidência das verticalidades e pouco corroboram para ampliar as horizontalidades ou, em outras palavras, não conduzem a fortalecer uma sinergia nas formas de viver no espaço.

Os cursos buscam um engendramento das demandas de cunho modernizantes, ou seja, atreladas aos serviços modernos, que na visão de LIMA; VASCONCELOS; FREITAS, são entendidos pelos seus nexos de comando (2011, p. $68)$.

Para os autores, "a principal propriedade dos serviços modernos seria a conectividade, tanto espacial (interligação dos territórios em múltiplas escalas) quanto setorial (imbricação dos setores econômicos)" (LIMA; VASCONCELOS; FREITAS, 2011, p. 70).

A definição e explicação dos serviços modernos [...] é a tecnologia, que condiciona a capacidade dos fluxos dos condutos nos diferentes territórios, segundo diversas escalas. Consideramos serviços modernos a ampla gama de serviços de informação, as funções de gestão, administração, segurança, saúde, educação especializada e capacitação tecnológica, pesquisa e desenvolvimento (P\&D), telecomunicações, telemática, marketing, comércio internacional, assessoria e consultoria, turismo, dentre outros (LIMA; VASCONCELOS; FREITAS, 2011, p. 70). 
Os serviços modernos são, portanto, a consolidação das lógicas que constituem esse período e sua incidência nos territórios. A oferta de cursos técnicos no contexto da educação pública formal, é impulsionada sobretudo, pela demanda de vagas no mercado de trabalho para atender esses serviços, pelo incentivo empresarial, pelos subsídios governamentais e, especialmente, pelas normas facilitadoras para sua implantação.

Os resultados são expressos no número de escolas instaladas com altos investimentos para o funcionamento dessa nova modalidade de ensino. A política apoiadora desse processo, - embora muitas vezes levada pelo próprio modo de produção de dominante - colabora para efetivá-lo em larga escala.

Contudo, esse modelo ganha força e evidência, conduzido pela necessidade de incorporar, cada vez mais, "o meio geográfico apropriado às atividades hegemônicas, ou seja, o meio técnico-científico-informacional" (SANTOS, 2007, p.89).

Podemos dizer que, nesse período, a organização territorial do Ceará está necessariamente referenciada a aspectos que integram 0 movimento contemporâneo de novos usos do território, com a ampliação da racionalização da produção, "porque o meio técnico-científico-informacional é o conjunto de lugares propícios ao uso racional dos atores da economia, da sociedade, da política e da cultura" (idem, p. 92).

Portanto, a reestruturação da economia e dos seus espaços de produção se integram mais aceleradamente à economia mundial. A ação do Estado e de seus mecanismos de intervenção e controle, na vida nacional e local, são alguns dos elementos do contexto mais recente que, embora redefinam mais intensamente as áreas de economia mais avançada, ou a região concentrada, englobam, de forma seletiva, todo o território nacional.

Embora seja o espaço geográfico um constructo humano, onde todos os agentes participam, ele é dirigido por alguns, coordenado e normatizado por uma minoria, que nem sempre representa os interesses coletivos, e que acaba por regular o uso do espaço produzido socialmente e por criar objetos técnicos que, em sua grande maioria, sugerem o papel que a sociedade deve desempenhar (SANTOS, 2012). 


\section{A opção pelas EEEPs: as demandas mercado e os usos do território}

Como já apresentado no capitulo 3, o Ceará tem equipado parte de seu território com objetos técnicos próprios do meio-técnico-científico-informacional no intuito de responder aos anseios do mercado mundial. Esse processo, por sua vez, acentuou relações de dependência financeira e tecnológica das nações desenvolvidas, bem como a necessidade de se integrar na economia global.

Nesse contexto, todas essas nuances trazem consigo novas ações que são determinadas a partir das novas atividades e necessidades criadas por meio da instalação desses novos objetos e novas ações; o que acarreta novos investimentos do Estado.

As EEPS são exemplos dessas políticas, pois o governo investe capital num setor da educação, de forma a responder as novas demandas do território, só que privilegiando os setores da economia global. Tudo isso se faz através de um consenso intermediado por símbolos que nos permitem aceitar a racionalidade do objeto, sem a reflexão do seu impacto real. Assim, pode-se dizer que "sua funcionalidade é extrema, mas seus fins últimos nos escapam. Essa intencionalidade é mercantil, mas não raro é também simbólica. Aliás, para ser mercantil, necessita ser simbólica antes" (SANTOS, 2012, p. 217).

Sobre isso Milton Santos diz que:

Quando o território é um meio técnico-científico, posso usar melhor a ciência, a técnica e a informação, por conseguinte seleciono os atores que comandam, facilito a concentração do capital, e portanto a concentração do mando, da regulação, a indicação das ações que devem ser feitas e daquelas que não devem, rapidamente instruo a respeito de que ações desejo que sejam feitas ali, naquele lugar, naquela hora, naquela circunstância, e crio todo o universo racional, facilitando pela constituição do território, que tem um efeito sobre a ação dos homens e de alguma maneira o refaz à imagem da racionalidade dos objetos do território e das ações que são possíveis de se realizar ali (SANTOS, 2007, p. 93).

A criação de um número considerável de escolas técnicas profissionais integradas ao ensino médio, no estado do Ceará, é talvez a melhor evidência da necessidade e do desejo de apropriar-se de uma qualificação que atenda aos 
interesses do mercado de trabalho, e um modo de refazer a imagem da racionalidade dos objetos do território.

Até porque as demandas locais, na sua maioria, não condizem com os cursos que são ofertados, sendo assim verificada uma difusão geográfica do ensino técnico profissional orientado pelas leis do mercado.

Os investimentos destinam-se a esse setor da educação, potencializando sua eficácia na manutenção dessa ordem. Pois, "los empleos urbanos están organizados em función de la complejidad de esa articulación internacional que requiere aparatos de gestión empresarial y de comunicación y procesamiento de la información tecnicamente avanzados" (LEMES, 2004, p.119).

O trabalho e os que participam dele são os que definem o uso do território, que se gera em função dessas novas atividades relacionadas ao comércio global e a partir de três dimensões prioritárias: as redes, as instituições e, espacialmente, a localização das empresas.

A partir disso, cumpre suprir as demandas provenientes desses novos objetos, seja no contexto da iniciativa privada, seja por meio do Estado que investe recursos a fim de atendê-las.

Nesse aspecto, o Ceará tem buscado se destacar pelos investimentos no desenvolvimento e ampliação do Ensino Médio integrado à educação profissional. Em 2008, foram construídas inicialmente 25 Escolas Estaduais de Educação Profissional (EEEP), em 20 municípios cearenses, e ofertavam quatro cursos profissionais de nível técnico: Informática, Enfermagem, Guia de Turismo e Segurança do Trabalho.

As primeiras escolas foram construídas na capital - Fortaleza - e, para as outras, utilizou-se como critério o fato de serem municípios sede das Coordenadorias Regionais de Desenvolvimento da Educação (CREDE).

A secretaria de educação também construiu em várias cidades novos prédios, reestruturou e refuncionalizou escolas estaduais para atender a educação profissional (Fotos 1, 2, 3, 4, 5, 6). Nesse caso, foram utilizados outros parâmetros para as elegerem; alguns dentre eles citam que estas escolas deveriam estar situadas em áreas de vulnerabilidade social; deveriam estar em condições mínimas necessárias à implantação; e seriam considerados os indicadores educacionais que estivessem abaixo do esperado. 
Foto 9 : EEEP Guiomar Belchior Aguiar - Biblioteca(Escola Padrão MEC)

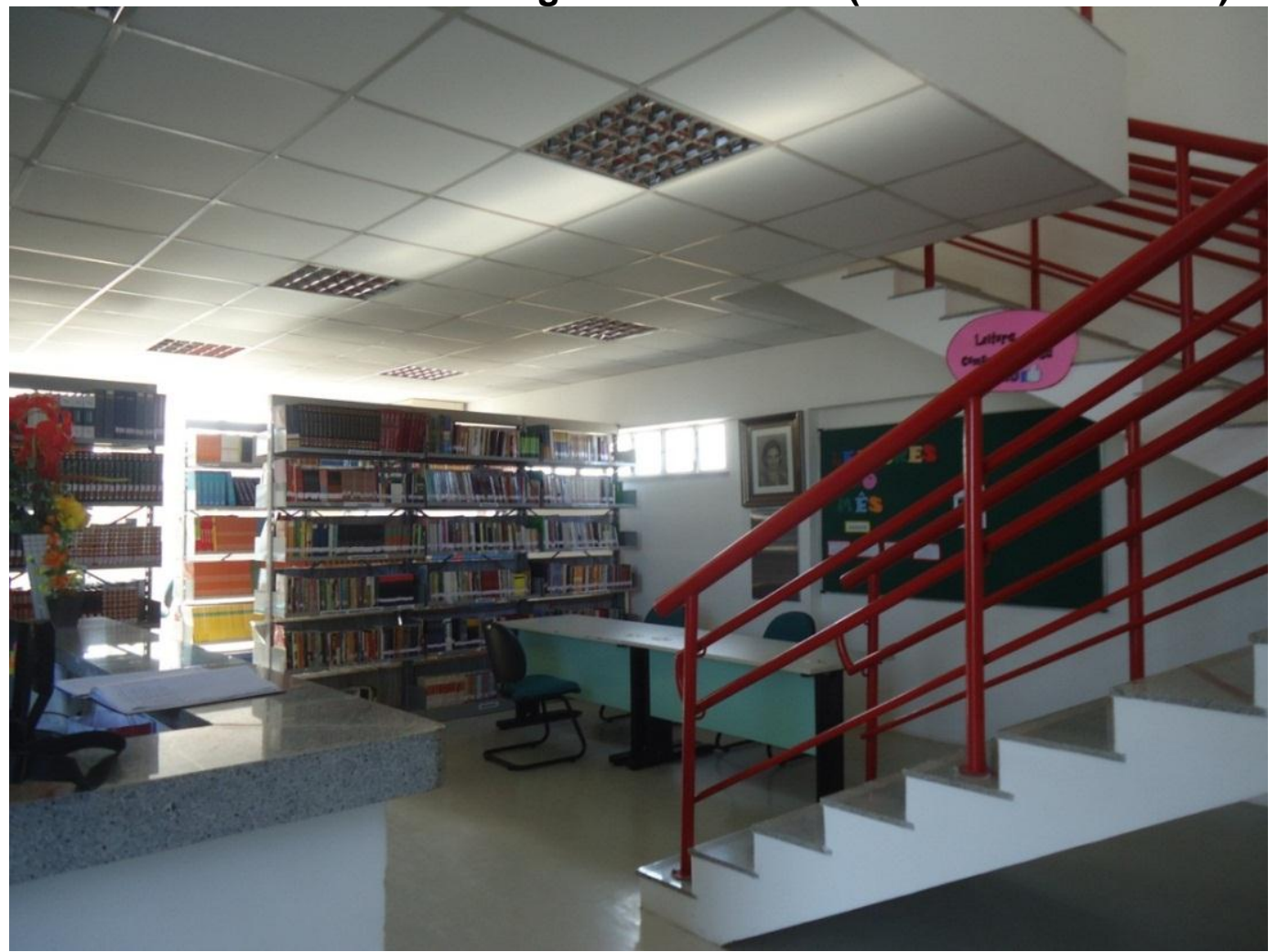

Fonte: Moraes, Jacqueline, 2016.

Foto 10: EEEP Guiomar Belchior Aguiar - Auditório (Escola Padrão MEC)

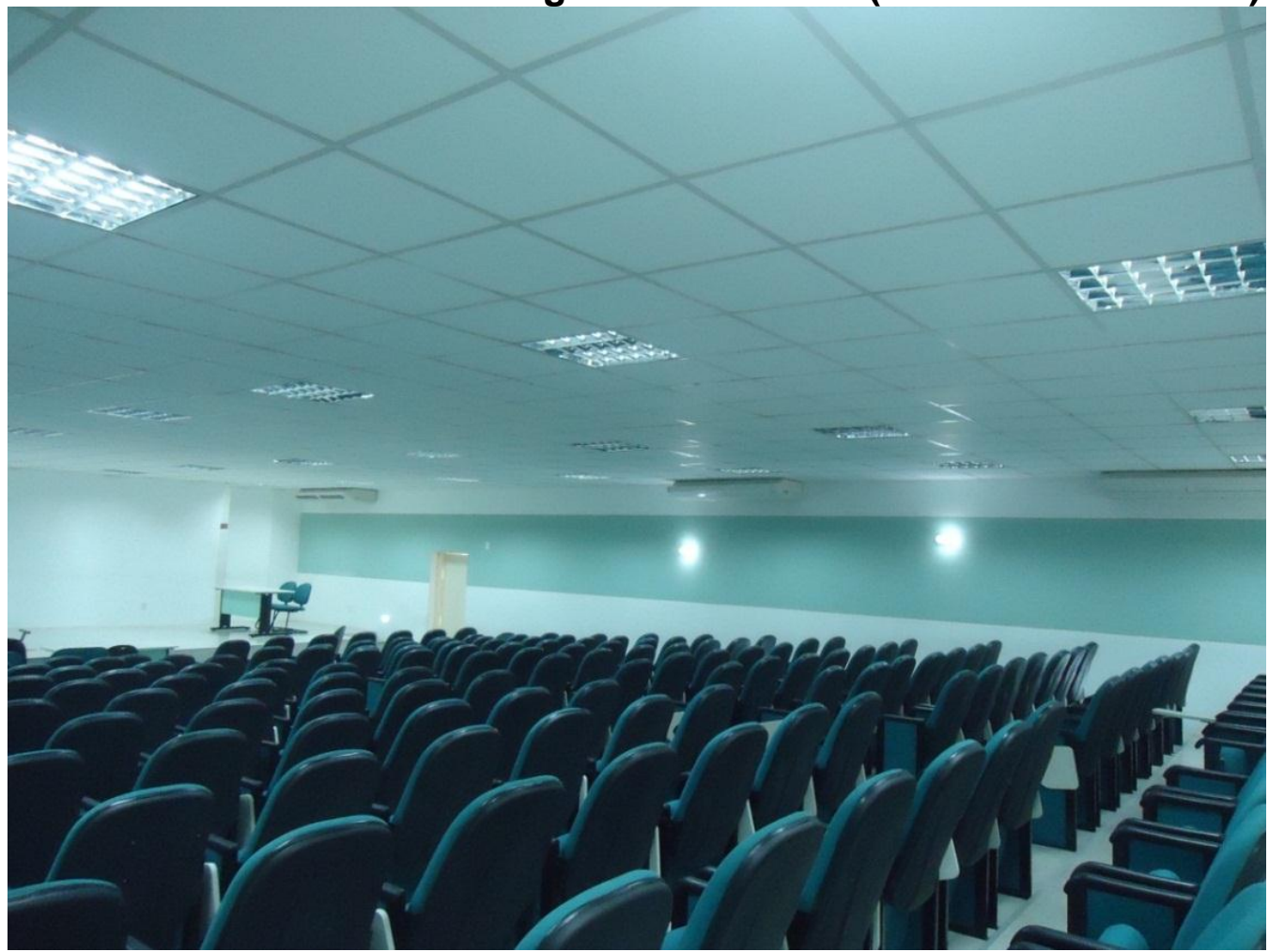

Fonte: Moraes, Jacqueline, 2016. 
11: EEEP Guiomar Belchior Aguiar - Sala de aula (Escola Padrão MEC)

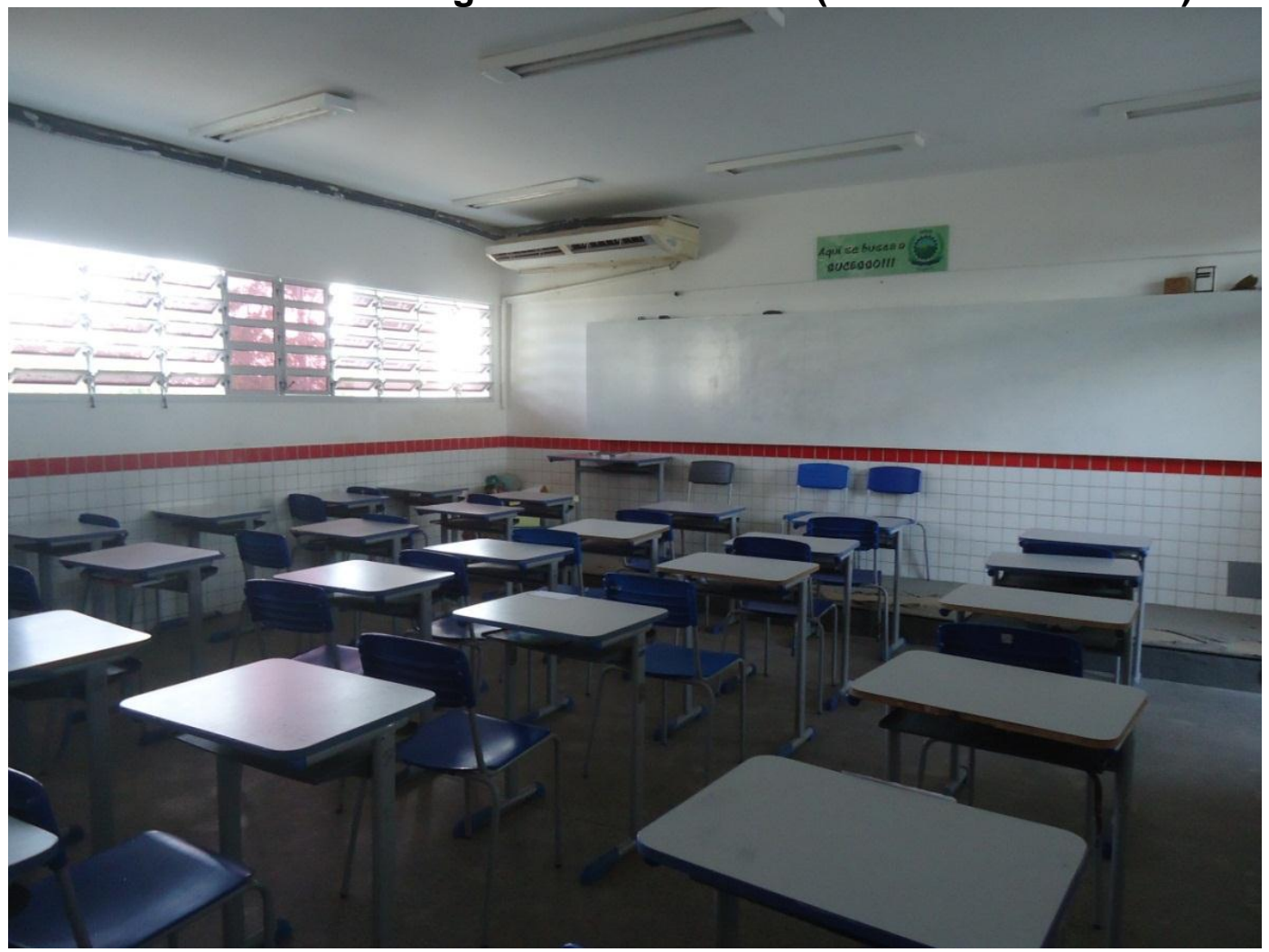

Fonte: Moraes, Jacqueline, 2016.

Foto12: Fachada da EEEP Dom Walfrido Teixeira Vieira - Antigo Liceu Sobral/CE (refuncionalizada para ofertar EP)

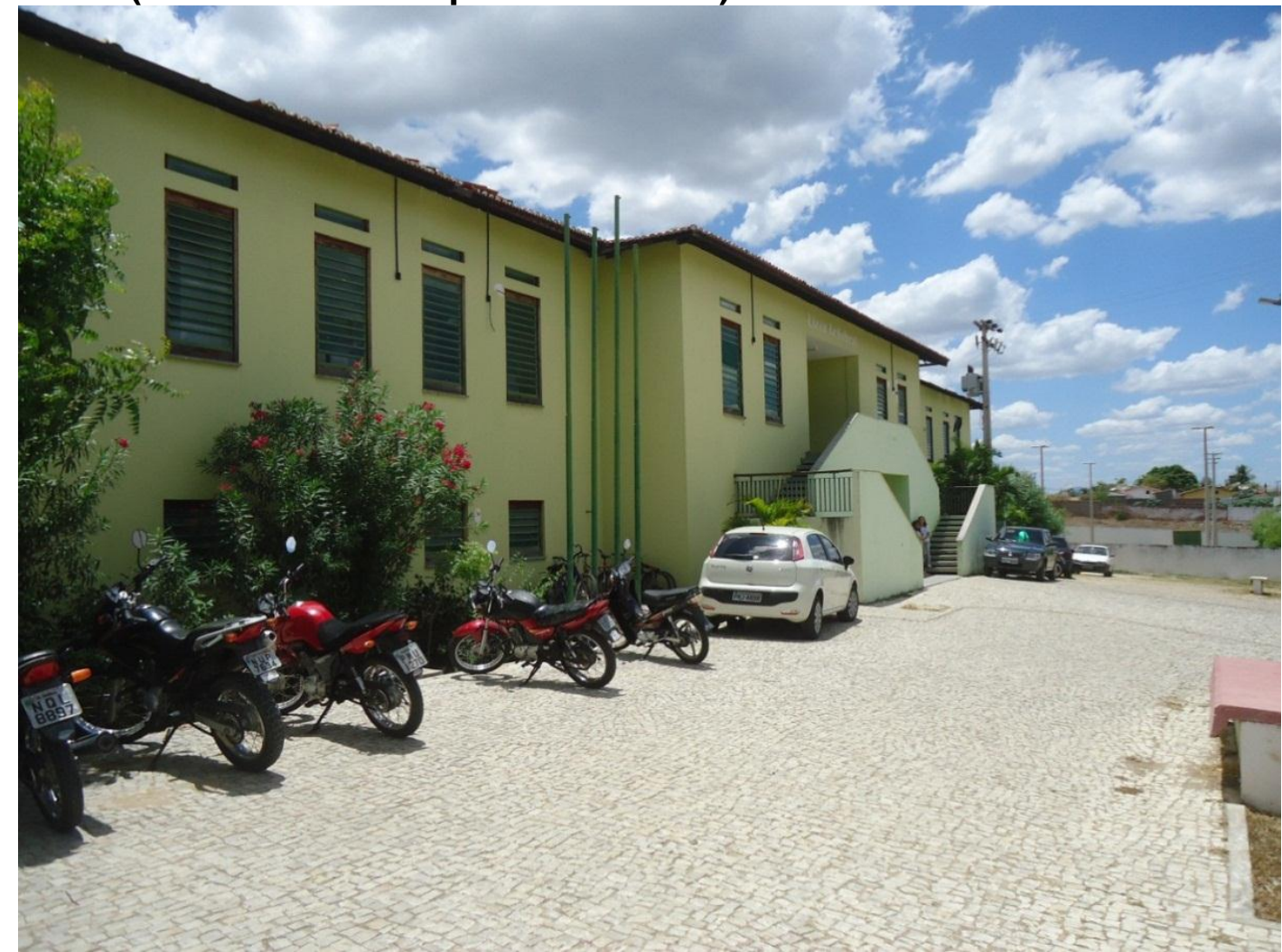

Foto: Moraes, Jacqueline, 2016. 
Foto13: Pátio da EEEP Dom Walfrido Teixeira Vieira - Antigo Liceu Antigo Liceu - Sobral/CE (refuncionalizada para ofertar EP)

Foto: Moraes, Jacqueline, 2016.

Foto 14: Fachada da EEEP Francisca Castro de Mesquita (readaptada para EEEP)

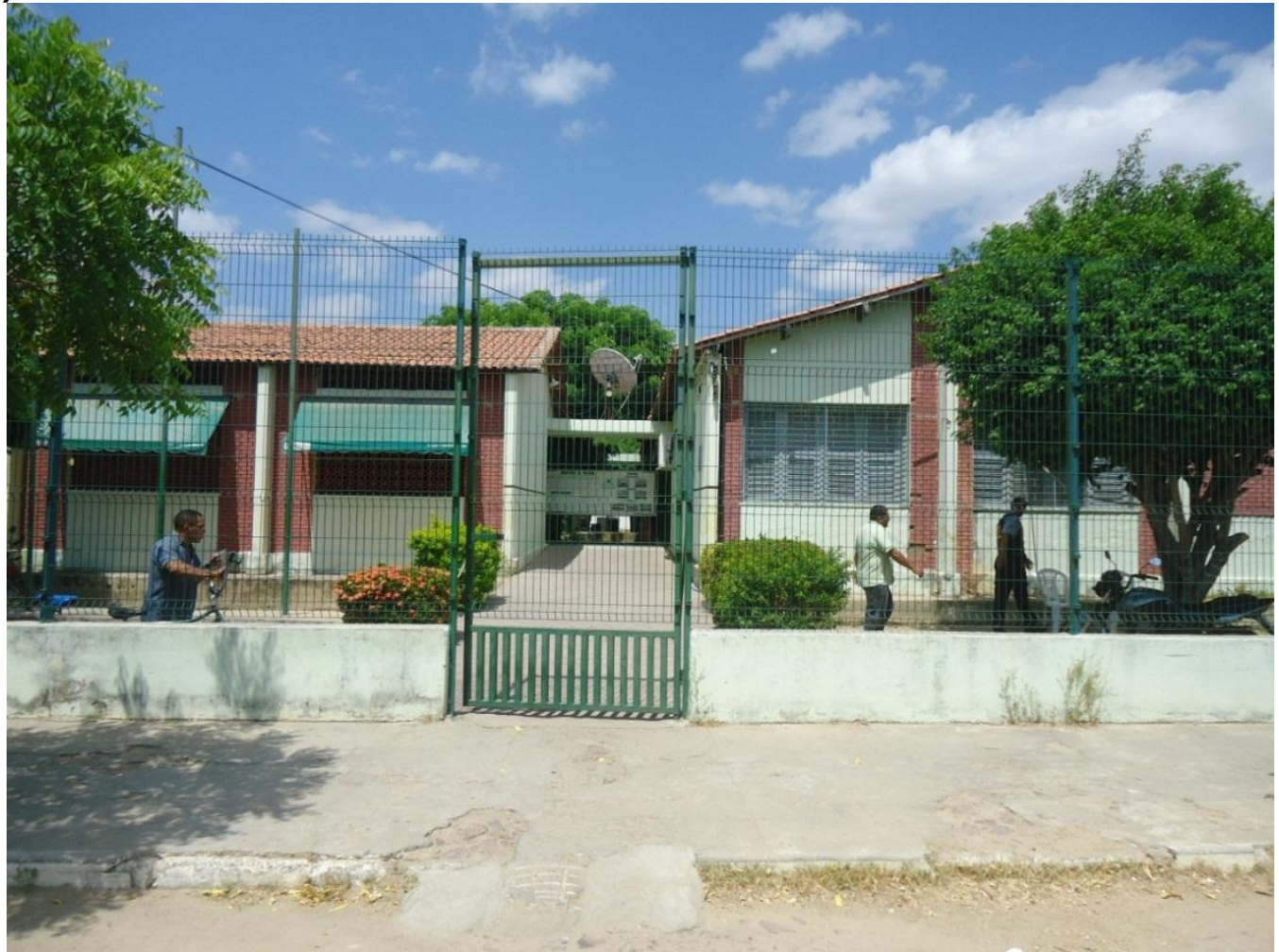

Foto: MORAES, Jacqueline, 2016. 
Foto 15: EEEP Francisca Castro de Mesquita - Refeitório (readaptada para EEEP)

Foto: MORAES, Jacqueline, 2016.

Foto 16: EEEP Francisca Castro de Mesquita - Sala de aula (readaptada para EEEP)

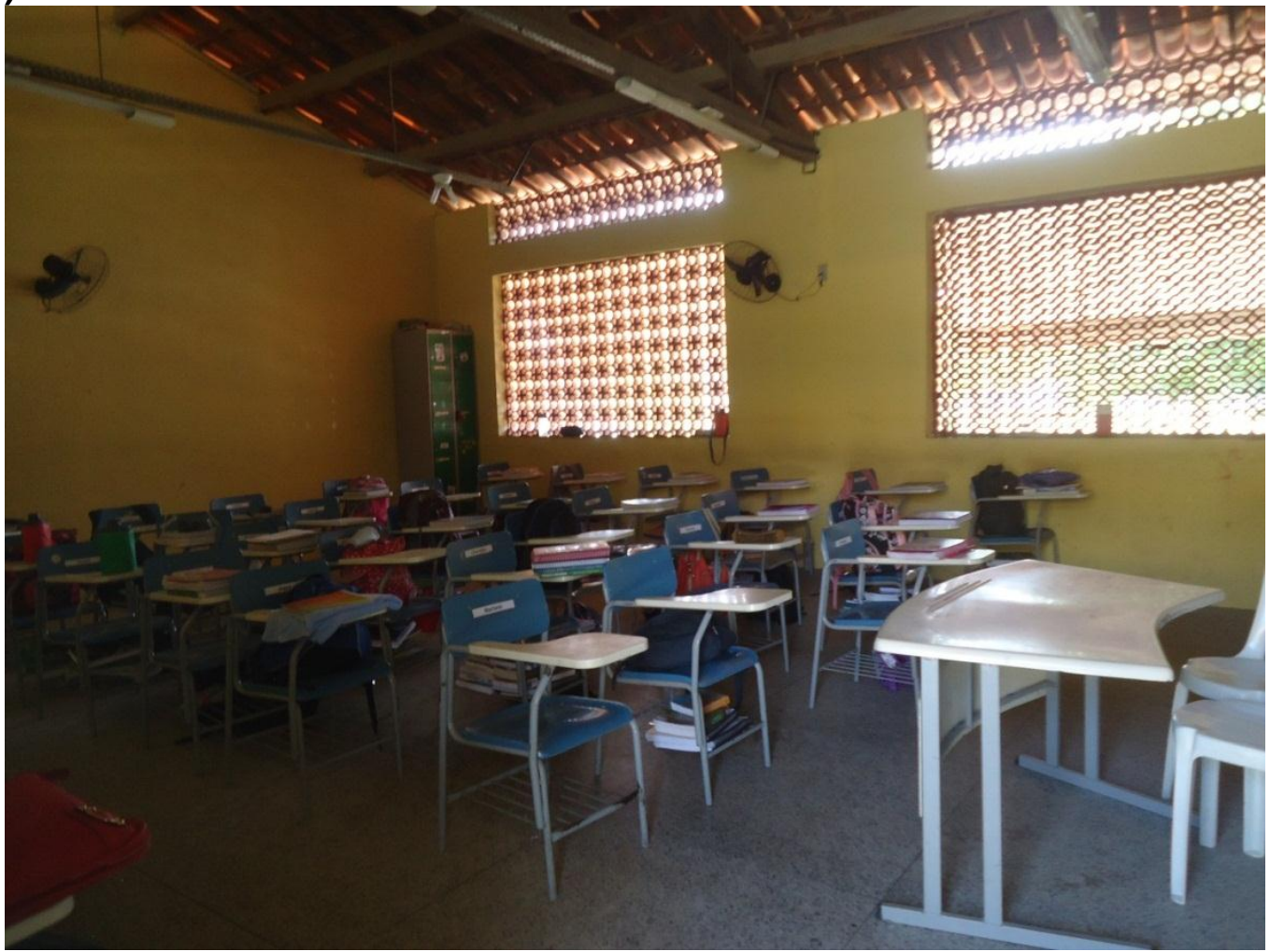

Foto: MORAES, Jacqueline, 2016. 
Segundo informações da Coordenadoria de Educação Profissional, a escolha dos cursos técnicos ofertados se deu em função das características socioeconômicas dos municípios inicialmente contemplados; em diálogo com os projetos estratégicos do governo estadual, no que se refere aos arranjos econômicos e produtivos, como o setor agrícola, industrial, assim como na área do turismo do Ceará. A mesma ainda afirma que esse critério continua a ser considerado na criação de novos cursos (CEARÁ, 2015).

Atualmente são 117 EEEPs distribuídas em vários municípios do Ceará com a oferta de 53 cursos agrupados em 12 eixos tecnológicos (tabela 1) (CEARA, SEDUC, 2015).

De acordo com a Secretaria de Educação do Estado do Ceará (SEDUC), a iniciativa do ensino médio integrado ao profissional busca: formar para o mercado de trabalho e proporcionar conhecimentos para o ingresso dos alunos em universidades (CEARÁ, SEDUC, 2015a).

Em conjunto com esses objetivos, a inciativa também estava vinculada à tentativa de melhoria dos índices educacionais do Ceará, sobretudo no ensino médio, hoje, tal justificativa não consta mais no site da Secretaria de Educação, porém, em entrevista, a coordenadora da Educação Profissional do estado, Professora Jussara de Luna Batista afirma que há uma preocupação com a melhoria dos índices educacionais, bem como com a permanência dos alunos até a conclusão do ensino médio.

De acordo com a coordenadora, a opção pela ampliação da rede também se justificou pelos bons índices e resultados que foram além das expectativas. "A partir desses resultados, foi que a rede foi crescendo e se fortalecendo".

Nesse contexto, vale ressaltar que a boa qualidade no aprendizado, que é um forte diferencial dessas escolas, pode se justificar também pelo critério para ingresso, pois os alunos são selecionados a partir do currículo escolar, ou seja, as mesmas recebem os considerados "melhores" alunos da rede pública.

Os cursos ofertados estão no contexto da política de sistematização e organização da oferta dos cursos técnicos no país, iniciado em 2008, pela publicação do primeiro Catálogo Nacional de Cursos Técnicos (CNCT).

Essa organização ocorreu quando o MEC, por intermédio da Secretaria de Educação Profissional e Tecnológica (SETEC), acolheu, no período de 2009 a 2011, às solicitações de atualização do CNCT, que foram provenientes de diversos setores 
envolvidos com a oferta de cursos técnicos de nível médio em todos os sistemas de ensino.

Foram encaminhadas ao MEC, demandas propostas por Estudantes, professores, gestores escolares, entidades de classe, sindicatos e associações, entre outros. Todas as solicitações recebidas foram organizadas e analisadas pelo MEC, com subsídios da Comissão Executiva Nacional de Avaliação do Catálogo Nacional de Cursos Técnicos (CONAC), composta por representantes do próprio MEC, do Conselho Nacional de Educação (CNE), de entidades diretamente ligadas à autorização e oferta de cursos técnicos, além de especialistas da área de educação profissional e tecnológica (BRASIL, 2010).

Segundo o MEC, o CNCT é resultado de um processo participativo, realizado a partir da análise de proposições apresentadas por agentes sociais e teve início em 2012. "A proposta de catálogo foi construída, em regime de colaboração com os sistemas de ensino, instituições de educação profissional e tecnológica, ministérios e órgãos relacionados ao exercício profissional e foi submetida à apreciação do Comitê Nacional de Políticas de Educação Profissional e Tecnológica (CoNPEP)" (BRASIL, MINISTERIO DA EDUCAÇÃO, 2016, p. 8).

As consultas a especialistas resultaram em recomendações sobre os cursos e foram avaliadas pela SETEC (Secretaria de Educação Profissional e Tecnológica), que as remeteu ao CNE (Conselho Nacional de Educação). Esse, por sua vez, se manifestou por meio do Parecer no 03 de 26 de janeiro de 2012, homologado pelo Ministro da Educação, o que possibilitou, enfim, a publicação da Resolução CNE/CEB no 04 de 06 de junho de 2012, que trata da atualização do Catálogo Nacional de Cursos Técnicos.

Como resultado do trabalho realizado, foram incorporados 35 novos cursos, considerados relevantes para a formação profissional dos alunos e que respondessem às demandas existentes.

Outros cursos que já figuravam no CNCT sofreram alterações, seja para adequação às normas vigentes, seja para melhor apresentar seu perfil de formação ou ainda para figurar em outro eixo, mais adequado às tecnologias utilizadas. (BRASIL. CATÁLAGO NACIONAL DOS CURSOS TÉCNICOS. Ministério da Educação. Secretaria de Educação Profissional e Tecnológica. Diretoria de Políticas de Educação Profissional e Tecnológica, 2012, p. 4). 
Nesse aspecto, pode-se dizer que a participação de diversos agentes incentivaram a oferta de cursos de interesse social, proporcionando uma adequação maior à realidade de algumas localidades. As horizontalidades aparecem, mas, com pouca evidência, pois as demandas não deixam de estar vinculadas à totalidade.

O que quer dizer que a educação técnica profissional integrada ao ensino médio teve suas bases alicerçadas na própria evolução das dinâmicas territoriais, que demandaram diferentes especializações frutos da divisão internacional do trabalho e do processo de constituição da sociedade, como resultado das políticas sociais.

À medida que o território se constitui a partir dos sistemas técnicos ${ }^{71}$ - que agregam técnicas representativas de diferentes épocas históricas -, há uma forma e distribuição do trabalho.

Há o que Milton Santos define como inércia dinâmica, ou seja,

Se o espaço organizado é também uma forma, um resultado objetivo da interação de múltiplas variáveis através da história, sua inércia é, pode-se dizer, dinâmica. Por inércia dinâmica queremos significar que as formas são tanto um resultado como uma condição para os processos. A estrutura espacial não é passiva, mas ativa, embora sua autonomia seja relativa, como acontece as demais estruturas sociais (SANTOS, por uma geografia nova, 1996, p. 148).

Neste aspecto, a sociedade se organiza para assimilar e usar os novos objetos dispostos no espaço geográfico; os quais impõem transformações e mudanças nos modos de vida sociais, apontando comportamentos e meios de gerir o espaço por intermédio de normas e leis.

No âmbito constitucional, as leis são as normas produzidas pelo Estado, porém, as mesmas, por sua vez, são criadas para garantir e propiciar a subordinação dos domínios da ação instrumental. Em tais condições, no atual período histórico, cria-se cada vez mais a necessidade de adoção, de um lado, de objetos suscetíveis de participar dessa ordem e, de outro, regras de ação e de comportamento que se subordine à 'organização' das 'coisas', a partir dessa ordem (SANTOS, 2012, p.228).

Nesse contexto, as políticas para a educação básica, na modalidade técnica profissional de nível médio integrada, no Ceará, não estão desvinculadas dessa

\footnotetext{
${ }^{71}$ Sistemas técnicos incluem de um lado, a materialidade e, de outro seus modos de organização e regulação.
} 
ordem. Sua inércia, atrelada à totalidade, se define através da normatização da educação profissional de nível médio no estado. Esta se deu pela LEI № 14.273, de 19 de dezembro de 2008, que dispõe sobre a criação das EEEPs, no âmbito da secretaria da educação, Art. 1ํㅡ, "sendo-lhes asseguradas as condições pedagógicas, administrativas e financeiras para a oferta de ensino médio técnico e outras modalidades de preparação para o trabalho". (CEARÁ, 2008).

Essa proposta foi alicerçada pela adesão ao Programa Brasil Profissionalizado, iniciativa do Programa Nacional de Acesso ao Ensino Técnico e Emprego (Pronatec), que tem por objetivo o fortalecimento do ensino médio integrado à educação profissional nas redes estaduais de educação profissional. Instituído no ano de 2007, foi criado por meio do Decreto no 6.302, de 12 de dezembro daquele ano.

O Programa Brasil Profissionalizado é voltado para subsidiar ações que visam à expansão, ampliação e modernização das escolas das redes estaduais de Educação Profissional e Tecnológica, com a finalidade de expandir e ampliar a oferta de cursos técnicos de nível médio, principalmente do ensino médio integrado à educação profissional e tecnológica.

As ações são geridas pela Secretaria de Educação Profissional e Tecnológica (Setec) do Ministério da Educação e pelo Fundo Nacional de Desenvolvimento da Educação (FNDE), e os recursos são repassados aos estados por intermédio de Termos de Compromissos, que visa a colaboração com Municípios, Distrito Federal e Estados, e a participação das famílias e da comunidade, mediante programas e ações de assistência técnica e financeira, visando a mobilização social pela melhoria da qualidade da educação básica (Decreto no 6.094, de 24 de Abril de 2007).

Para garantir a articulação entre a escola e o trabalho, o ensino médio, integrado à educação profissional, passa a ser ofertado nas Escolas Estaduais de Educação Profissional - EEEP; a jornada proposta é de tempo integral.

As aulas são distribuídas em dois turnos, e o currículo é composto pela Base Comum Nacional, que compõe as disciplinas do ensino médio regular, e pela base profissionalizante de nível médio, comportando as disciplinas profissionalizantes, bem como a parte diversificada que envolve Projeto de vida; Mundo do Trabalho, Temáticas, Práticas e Vivências; Empreendedorismo; Formação para a cidadania, entre outras (SEDUC-CE, 2013). 
Cabe ressaltar uma particularidade sobre a gestão dessas escolas, pois a mesma tem por base um modelo de gerência empresarial denominado TESE (Tecnologia Empresarial Socioeducacional). Esse modelo de gestão se baseia na Tecnologia Empresarial Odebrecht (TEO), que foi adaptada para essa modalidade de ensino, bem como agrega os 'quatro pilares do conhecimento' contidos no Relatório de Jacques Delors, quais sejam: aprender a conhecer - adquirir os instrumentos da compreensão; aprender a fazer - poder agir sobre o meio envolvente; aprender a viver juntos (conviver) - participar e cooperar com os outros em todas as atividades humanas; e aprender a ser - realizar-se como pessoa em sua plenitude. Foi sistematizada uma variante a ser utilizada no ambiente escolar (TESE/TEO, 2008, p. 7).

Justificada como um bom fundamento para gerir escolas, a TESE norteia a condução educação escolar dessas escolas, para uma formação que atenda ao tipo de trabalhador exigido para mercado de trabalho, ou seja, o empreendedor, inovador, inventivo, flexível, com senso de oportunidade, com capacidade de liderar e provocar mudanças, etc.

A educação técnica de nível médio, nesse âmbito, adequa suas finalidades às orientações neoliberais de formação dos trabalhadores. É a força da incidência das verticalidades, ditando comportamentos que possam fortalecer os ideais neoliberais de monitoramento e ajustamento a uma forma de solidariedade capaz de organizar, modificar, induzir a um modelo de educação para atender as demandas do mercado.

Sobre o mercado no período atual, Santos fala que o mesmo,

atravessa tudo, inclusive a consciência das pessoas. Mercado das coisas, inclusive a natureza; mercado das ideias, inclusive a ciência e a informação; mercado político. Justamente, a versão política dessa globalização perversa é a democracia de mercado. O neoliberalismo é o outro braço dessa globalização perversa, e ambos esses braços - democracia de mercado e neoliberalismo - são necessários para reduzir as possibilidades de afirmação das formas de viver cuja solidariedade é baseada na contiguidade, na vizinhança solidária, isto é, no território compartido. Se essa convivência conhece uma regulação exterior, esta se combina com formas nacionais e locais de regulação. O conflito entre essas normas deve, hoje, ser um dado fundamental na análise geográfica." Milton Santos, "O retorno do território", em Milton Santos, Maria Adélia de Souza e María Laura Silveira, Território, globalização e fragmentação, São Paulo: Hucitec/Anpur, 1994, p. 18/19. 
Eis uma base para a reflexão da condução da educação técnica profissional. Todo esse processo tem exigido a criação de normas, seja para dar coerência interna às organizações transnacionais, no sentido de atender as suas exigências, seja para regular as ações conflitantes entre os anseios das grandes corporações e a realidade do espaço de todos.

Com efeito, esse conjunto de relações, adequadas à lógica global, acaba por potencializar a dependência e subordinação aos interesses hegemônicos, que se fazem por meio de normas, leis e da política, e que fazem prevalecer a tão antiga subordinação da classe menos favorecida de nossa sociedade, aos interesses da manutenção da lógica capitalista da atualidade. 
CAPÍTULO 6

A CONDUÇÃO DA EDUCAÇÃO NO CEARÁ: ELEMENTOS PARA PENSAR UMA FORMAÇÃO HUMANISTA

Neste capítulo, serão discutidas algumas das implicações que a modalidade ensino técnico profissional pode conferir ao território.

A análise do uso do território vem buscar debater e ampliar as formas de perceber os conflitos entre $o$ ato de produzir para um mercado e de viver; visto que esta é pensada para atender a determinados setores sociais, e sua oferta muitas vezes não está atrelada à economia das localidades.

Sendo assim, esse capítulo se propõe a contribuir para este diálogo, por meio da produção do conhecimento geográfico, abrindo alternativas para discutir as ações advindas das políticas pensadas para uma demanda alheia à realidade local, enquanto se busca analisar outras alternativas para a educação técnica de nível médio integrada, com vistas a uma possível constituição teórica e prática para a efetivação de outras possibilidades de se pensar a educação, além da técnica, mas, especialmente, como outras formas de desenvolvimento, a que considera os moldes mais humanísticos. 


\section{Capítulo 6. A condução da Educação no Ceará: elementos para pensar uma formação humanista}

"A imoralidade e a desordem estão na manutenção de uma 'ordem' injusta"

Paulo Freire

O Ceará apresenta uma forte contradição no uso do território. Verticalidades e horizontalidades se encontram e constituem sua organização, "essa dialética se afirma mediante um controle local da parcela técnica da produção e um controle remoto da parcela política da produção" (SANTOS, 2008, p. 141), assim, cidades locais ou regionais tem certa autonomia sobre uma porção do território por meio de sua configuração técnica, onde os agentes locais vivem e usam o território. Por outro lado, há também um controle distante, feito pelas cidades mundiais, que interessam aos agentes hegemônicos e se realiza localmente sobre a parcela política da produção.

No que concerne a verticalidades, essas se superpõem, reunindo áreas e pontos distantes a serviço dos atores hegemônicos. Como mostra os mapas 8 e mapa 9 alguns serviços e infraestruturas se concentram nessas áreas e pontos, onde a densidade técnica é maior, essas por sua vez, induzem o aparecimento de demandas voltadas para seu atendimento. São "os vetores da integração hierárquica regulada" (SANTOS, 1996, p.54), que se realizam através de ordens técnicas, políticas e financeiras a partir de um comando à custa de normas rígidas (SANTOS, 2012, p. 287).

Nessas áreas os cursos técnicos tem uma maior viabilidade do ponto de vista do atendimento das demandas, visto que a uma maior concentração de fixos e fluxos, bem como de objetos técnicos voltados a ampliação e permanência desse modelo de uso do território. Esses dão a configuração territorial e define o próprio território, são cada vez mais carregados de informação e voltados ao estabelecimento de atividades hegemônicas fazendo com que outros fixos surjam e se multiplique. 
Mapa 8: ESTADO DO CEARÁ: Número de Empresas ou Organizações de Educação por Município. 2010.

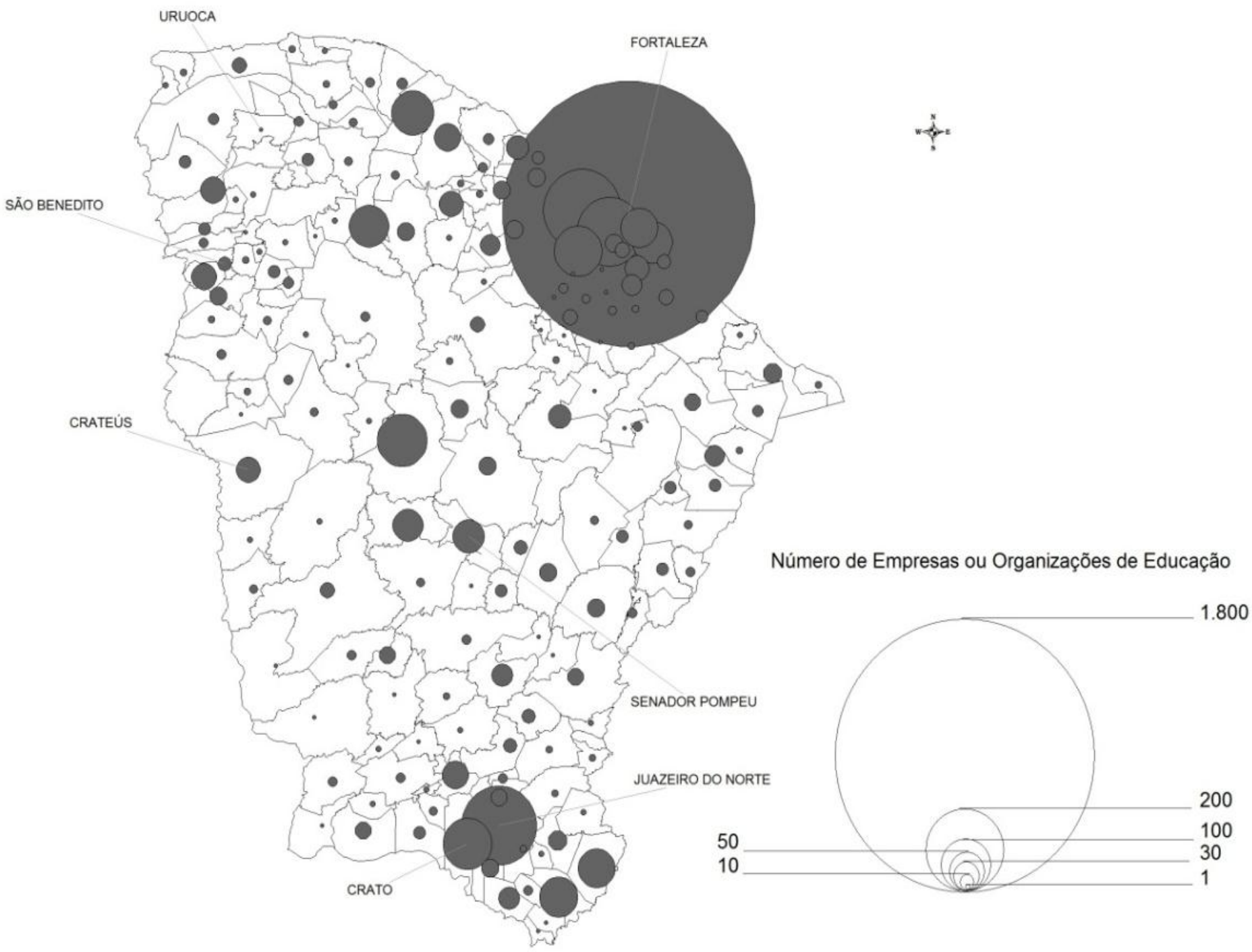

Fonte: Instituto Brasileiro de Geografia e Estatistica - IBGE. Cadastro Central de Empresas. 2010 Elaboração Cartográfica: Markelly Fonseca de Araújo. Software Mapinfo Professional. 
MAPA 9: ESTADO DO CEARÁ: Municípios selecionados pela pesquisa de tese por total de empresas industriais. 2012.

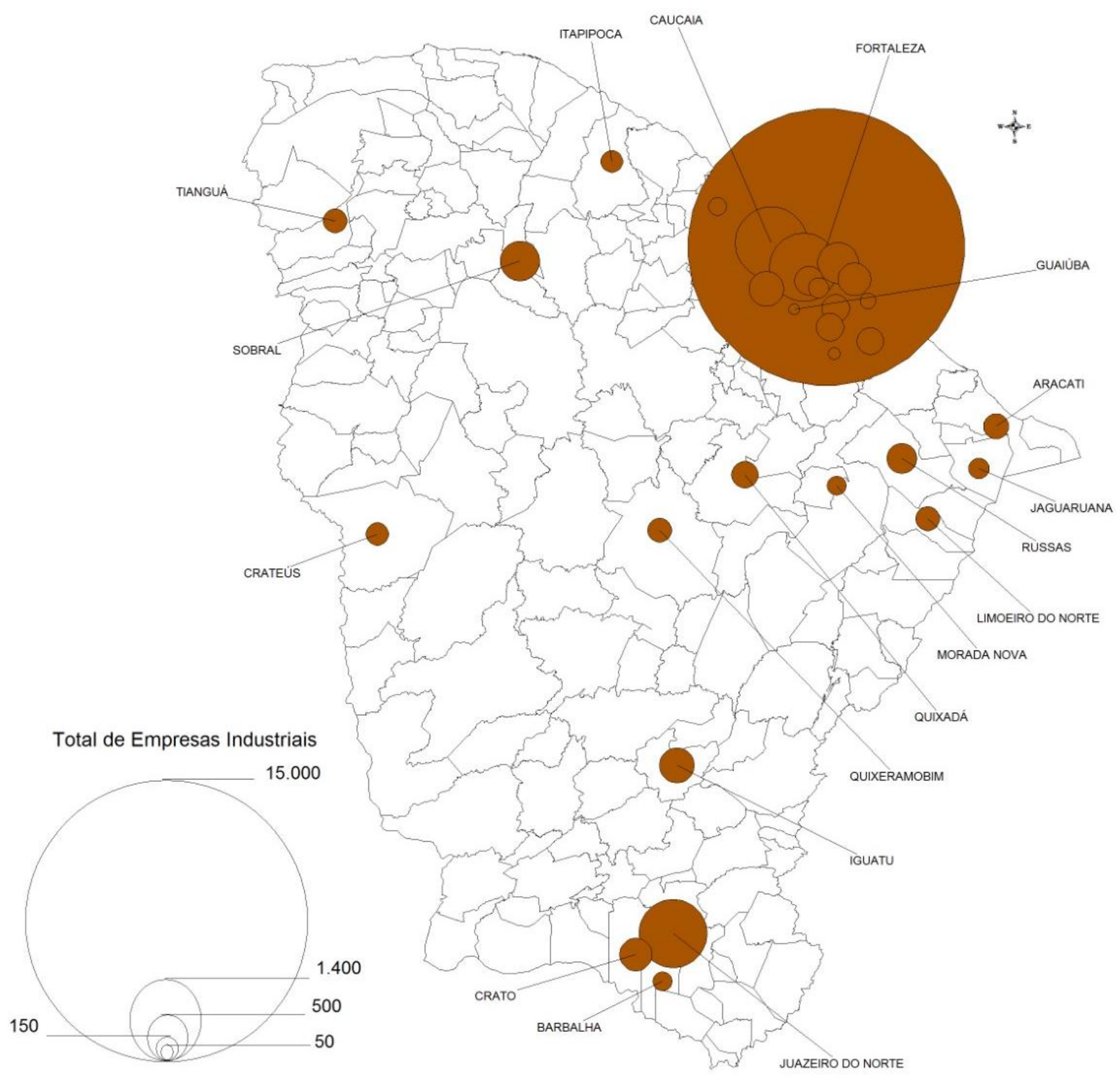

Fonte: Secretaria da Fazenda - SEFAZ. In: Instituto de Pesquisa e Estatística Econômica do Ceará/lPECE, 2012. "Municipios selecionados pela pesquisa de tese. Exclui-se aqueles que năo estavam nas regiōes investigadas. Elaboração Cartográfica: Markelly Fonseca de Araujo. Software Maplnfo Professional. 
Esses territórios usados são atualmente, um sistema de objetos e ações cada vez mais artificiais e estranhos ao lugar, porém, não alheios, pois são interligados por redes diversas que, de certo modo se espalham por todo o planeta, ainda que com densidade desigual, segundo os territórios, continentes e países. (SANTOS, 2012).

Assim, têm-se as áreas adaptadas às exigências das ações características da globalização (espaços luminosos); e as áreas pouco dotadas das virtualidades necessárias ao presente momento (espaços opacos) (MAPA 9). Ambos são condição de realização da economia e da sociedade globais (ou seja, a condição da globalização e do atual meio geográfico). Portanto induzem o aparecimento das demandas para que produzam os resultados esperados. 


\section{MAPA 10. ESTADO DO CEARÁ: Densidades técnicas e populacionais segundo a pesquisa de tese.}

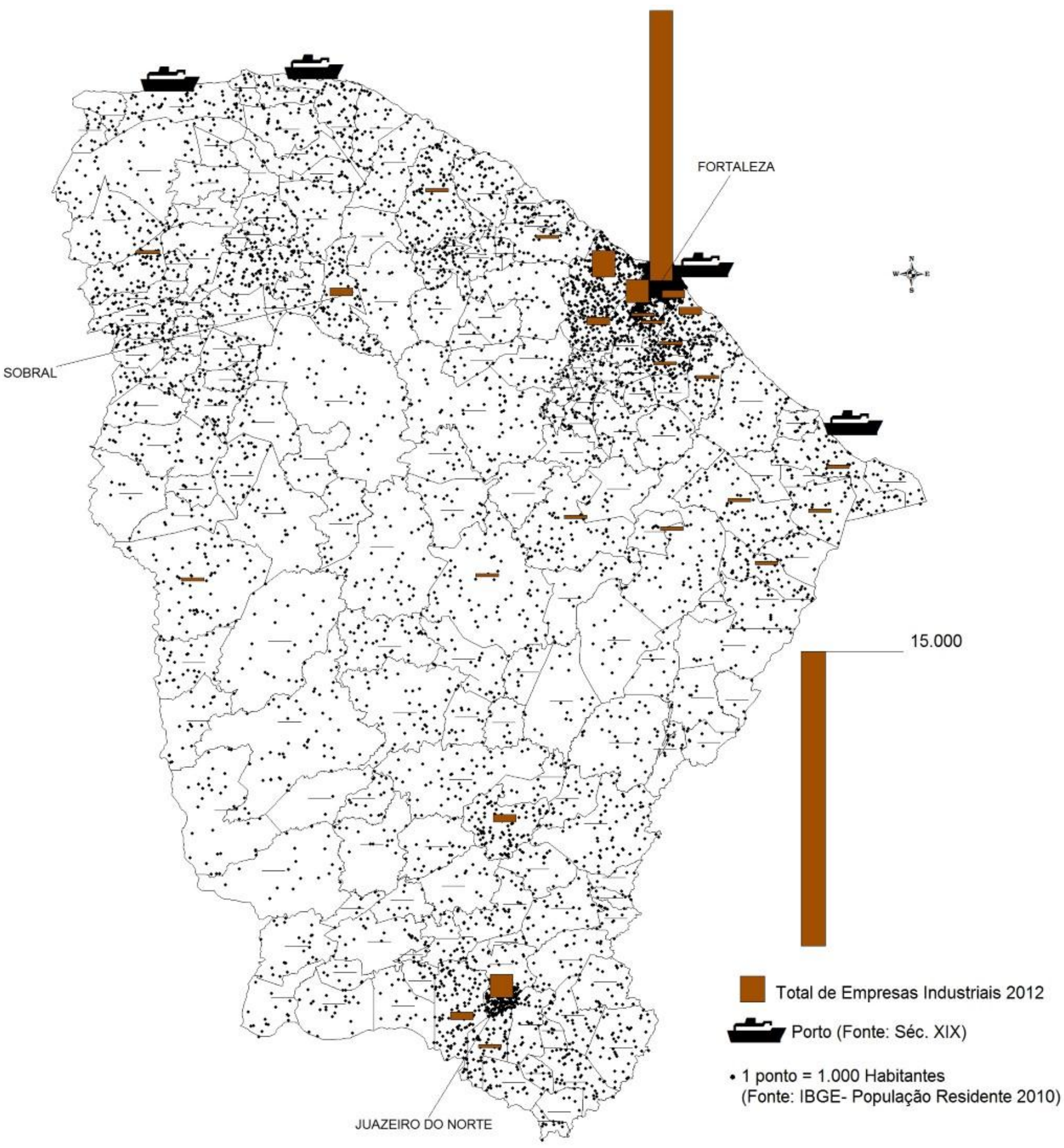

Fonte Portos: Superintendência de Desenvolvimento do estado do Ceará (Adaptação tabela) In: LIMA, 2008, p. 158 Fonte População: IBGE-2010. Fonte Empresas industriais: SEFAZ In: IPECE - 2012.

Elaboração Cartográfica: Markelly Fonseca de Araujo. Software MapInfo Professional. 
Nessa perspectiva se dá a opção de cursos técnicos, principalmente aqueles que subsidiam o atendimento dos usos verticais. Distanciando-se cada vez mais do ideal de sociedade orgânica e proporcionando a manutenção das ordens técnicas, políticas e financeiras a serviço dos vetores que se instalam nos lugares e que pouco se importam com o que está em seu entorno. É o que corresponde, sobretudo, às ações das empresas globais.

Assim, os vetores dessa ordem chegam a todas as áreas, porém sua ação não se realiza do mesmo modo. Por exemplo: nas áreas densas a manutenção e a constituição de mão-de-obra, encontra campo para garantir a sua permanência e ampliação. Já nas áreas opacas, isso não ocorre, ao contrário, esse modelo traz desorganização, pois não há campo para inserir os novos trabalhadores que chegam ao mercado de trabalho, visto que, suas formações muitas vezes, não atendem as demandas locais.

Segundo Santos "os vetores de modernização são entrópicos. Eles trazem desordem aos subespaços em que se instalam e a ordem que criam é em seu próprio benefício. E a união vertical (...) está sempre sendo posta em jogo e não sobrevive senão à custa de normas rígidas" (SANTOS, 2012, p. 287).

A horizontalidade é o resultado da vizinhança, da coabitação, da coexistência do diverso, que é objeto do geógrafo. Só que as verticalidades perturbam as horizontalidades, embora as horizontalidades também perturbem as verticalidades, porque as primeiras visam a eficácia e agem com este sentido sobre as segundas" (SANTOS, 2000, p.53).

Ambos intervêm na configuração do território e, é dessa relação lugar/mundo que surgem as demandas das localidades e concomitantemente as ações para efetivá-las. Acontece que essas demandas, muitas vezes, não atendem às demandas internas da sociedade cearense; ou seja, "os nexos distantes primam sobre os nexos próximos e o interesse econômico sobre o interesse social" (SANTOS, 2008, p. 136),

As demandas por equipamentos e serviços de interesse coletivo como a Educação (de qualidade e para todos), investimentos em moradia, saúde, dentre outros, perdem espaço ou se adequam para atender aos grandes investimentos de interesse econômicos. Visto que os investimentos destinados para alguns setores são vultosos, estes poderiam suprir carências para proporcionar uma melhor qualidade de vida para a população, bem como melhor atender a educação como 
um todo, ou seja, melhorar escolas já existentes, investindo em qualidade, formação de profissionais e melhores estruturas.

Dados revelam que, no período de 2007 a 2012, a secretaria de Infraestrutura respondeu pelo maior investimento acumulado $(28,7 \%)$, seguida da secretaria de Recursos Hídricos (12,57\%) e Turismo (10,16\%). De certo modo, dada a magnitude dos investimentos realizados nesse período, relativamente ao observado no quinquênio imediatamente anterior, observa-se uma priorização da Gestão pública estadual desse período, no sentido de direcionar boa parte dos recursos orçamentários para projetos estruturantes que viriam a contribuir para dinamizar a economia cearense.

No que se refere aos investimentos na Saúde, esse apresentou uma participação de $8 \%$ entre 2007 a 2012 registrou uma participação de $8 \%$ no total dos investimentos públicos. No tocante à educação, os investimentos totais do Estado no período de 2007 a 2012, obteve uma participação de $9,13 \%$ nos investimentos totais.

Ressaltam-se os esforços empreendidos ao desenvolvimento econômico do estado, por meio da construção de escolas estaduais de educação profissional, escolas estaduais de ensino médio e o programa alfabetização na idade certa (PAIC) mostraram o esforço despendido para o desenvolvimento educacional do Estado, nos anos de 2007 a 2012 (IPECE, 2014, p. 125);

Sobre o ensino técnico, considera-se que esse tem sua importância, haja vista que a técnica tem um papel importante na realização da sociedade. Contudo, alguns pontos devem ser revistos e repensados, pois muitos dos cursos ofertados não estão de acordo com a proposta da secretaria de educação do estado, que justifica o modelo de educação adotado segundo as características socioeconômicas dos municípios (CEARÁ, 2015), baseando-se numa solidariedade organizacional, obedientes à lei da acumulação global viabilizada pela informação (Ricardo CASTILLO, Rubens de TOLEDO Jr. \& Julia ANDRADE, 2012). Pode-se exemplificar a partir da quantidade de cursos técnicos em enfermagem, informática e redes, administração, comércio, finanças, etc.

Considerando-se as demandas das localidades, tem-se uma oferta que pouco se enquadra nas necessidades e na realidade de algumas cidades, pois criase uma oferta de técnicos que excederá e muito as demandas por esse tipo de serviço. 
Além do mais, capacita-se para atender a uma demanda do mercado que, muitas vezes, tem seu grau de concentração nas zonas luminosas ou de maiores densidades técnicas, o que faz com que esses novos técnicos migrem para essas localidades em busca de trabalho.

Por outro lado, as potencialidades que poderiam ser fortalecidas ou repensadas, a partir do ensino técnico integral, são deixadas de lado; o que pode ser explicado pela força de uma ideologia dominante ${ }^{72}$, que dificulta uma percepção mais clara da realidade.

Paro (2002) discorre nessa vertente quando fala das instituições de educação em termos superestruturais, as quais são condicionadas, no decorrer do tempo, de acordo com as determinações reprodutivas em mutação do sistema capitalista, que buscam intencionalmente conduzi-las para estender sobremaneira a hegemonia do mercado. No entanto, a contradição da escola consiste em fornecer também os elementos intelectuais que possam permitir a classe trabalhadora compreender a realidade social e, assim, dá-lhe subsídios para modificar essa realidade (PARO, 2002).

Em outras palavras, no âmbito da mesma, há um encontro dos anseios do espaço banal, da necessidade de viver e usar o território que contribui para a constituição de resistências e uma maior autonomia dos lugares, assim como, para a produção de conhecimentos, para responder a tudo isso, e, ao mesmo tempo, a força de uma hegemonia dominante que utiliza os sistemas de objetos para agir no fortalecimento e manutenção da lógica do mercado.

$\mathrm{Na}$ atualidade, a escola vem sendo cada vez mais utilizada para atender aos anseios do mercado passando a exercer um papel preponderante para a manutenção desse sistema, uma vez que se insere nele e o impulsiona. "Trata-se da expansão dos mecanismos econômicos do capitalismo para o conjunto das instituições sociais, colocando em evidência a dimensão política do capital" (BRUNO, 2011, p. 546).

\footnotetext{
${ }^{72}$ Os cursos e o próprio currículo são conduzidos pela ação eficaz de um conjunto de pensamentos que seguem em sua maioria às demandas do mercado, estas por sua vez são impostas verticalmente e suprimem outras formas de pensar o espaço geográfico. Ressalta-se que a educação técnica de nível médio integral poderia e deveria ser uma forma de resistência na busca de alternativas para prover outras possibilidades de viver, onde se levasse em conta os seres humanos e não o mercado, visto que esta abrange tanto o currículo regular como o técnico.
} 
A escola tem diminuído cada vez mais as práticas sociais, que busca uma consciência coletiva para propiciar uma coesão social mais humana. Em seu lugar se fortalece o apelo do mercado, com seus conceitos de concorrência, flexibilidade, velocidade.

A consciência coletiva é reduzida, e a solidariedade mecânica ${ }^{73}$ é cada vez mais substituída pela solidariedade orgânica $^{74}$, em que há a valorização do individual. Essa forma de organização atinge a educação, tornando-a também 'orgânica'75, pois sua orientação, que se dá pelo uso do território, agrega uma maneira autônoma e especializada (espaço banal), mas obediente à força do mercado, que tem o seu modo de uso mais eficaz.

Essa eficácia, por sua vez, é também propiciada pelo Estado, quando investe em infraestruturas de interesse dos agentes hegemônicos. As consequências disso é a subordinação cada vez maior às empresas e aos seus mandos.

Com efeito, essa lógica acaba por potencializar a dependência ao modo de produção capitalista que hoje impera, e a inserção subalterna na divisão internacional do trabalho.

É por esses e outros motivos que as EEEPs apresentam em sua organização uma orientação que muito se adequa ao sistema de produção para o mercado. Na medida em que é engendrada no modo de produção capitalista, serve principalmente aos interesses da classe detentora dos meios de produção, fortalecendo a dependência ao capital.

Basta uma análise mais aprofundada do EEEPs nas localidades que dispõem desses objetos, para perceber que, em sua constituição, há uma orientação capaz de agregar as verticalidades escolhidas pelo capital, e adaptá-los a seus fins e a um sistema de valores sociais, políticos e culturais.

\footnotetext{
73 "Baseia-se nas semelhanças entre os indivíduos, liga o indivíduo ao grupo, reduz as diferenças para ressaltar a consciência coletiva" (DURKHEIM, 1999, p.71). Na solidariedade mecânica o indivíduo se conecta diretamente à sociedade, prevalecendo as necessidades coletivas em detrimento das individualidades.

${ }^{74}$ Não há uma maior valorização daquilo que é coletivo, há uma organicidade porque há uma interdependência mediada pela divisão do trabalho (destaque para a consciência individual).

${ }^{75}$ O termo "orgânica" é utilizado pelo autor em referência à morfologia e fisiologia dos animais superiores, em que diferentes órgãos atuam de maneira autônoma e especializada, ao mesmo tempo em que obedecem ao sistema nervoso central, numa relação de complementaridade e mútua dependência.
} 
A partir do momento que essas escolas se instalam, trazem com elas, componentes que fazem assegurar a adoção de um pensamento pouco significativo para o fortalecimento das potencialidades locais, e para o surgimento de demandas alternativas àquelas propostas por uma hegemonia corporativa.

Também nessa linha de pensamento, ousa-se falar da educação regular pública e sua condução atual, que não está isenta das verticalidades, da acumulação e reprodução capitalista que as atingem, desagregando seus propósitos e impondo formas de pensar que pouco contribui para a construção de um modo de vida mais igualitário.

As propostas educacionais, pouco tem levado em conta os problemas da atualidade, como a questão das drogas, da indisciplina, das variadas formas de violência, dentre outros. A escola pública regular continua exercendo ainda seu papel de acolhedora de problemas sociais. Porém, sem os devidos suportes (estruturais e humanos) para combatê-los.

$E$ isso ocorre não por falta de condições, sejam elas financeiras ou estruturais ou por falta de profissionais, mas pelas políticas públicas que teimam em não levar a educação regular, laica e obrigatória a sério.

Isso pode ser comprovado pelos investimentos em outros setores da economia para assegurar a fluidez, como os grandes empreendimentos para atrair capital estrangeiro e para promover privilégios para uma pequena parcela da sociedade.

Esse modo de conduzir a educação faz perpetuar a tão antiga subordinação da classe menos favorecida de nossa sociedade aos interesses da classe dominante, ou seja, dar continuidade à manutenção da exploração da massa proletária e do trabalho produtivo - que cresce exponencialmente, e cada dia aumenta sua lista de profissões e especializações, contribuintes da lógica hegemônica atual; ao invés de investir em formação intelectual, humanista e proativa, a única capaz de levar atualmente o homem a elaboração de um projeto de mundo mais igualitário.

As EEEPs estão no contexto dessa ordem perversa. Por trás dessas, estão às demandas criadas pela modernização e concentração de capitais fixos, decorrentes de uma pressão concorrencial global, que exige uma maior exigência de qualificação, sobretudo nas áreas técnicas. 
O Estado acaba cedendo e promovendo as condições necessárias para garantir a inserção do capital. Desse modo, oferece uma contrapartida, uma mão-deobra barata e mais qualificada no contexto da flexibilidade.

Assim, a opção pelo modelo das EEEPs adotado no Ceará, atende aos novos objetos que conclamam a adoção de uma adaptação a seus usos (ver gráfico 1).

\section{Gráfico 2: Número de cursos ofertados nas EEEPs}

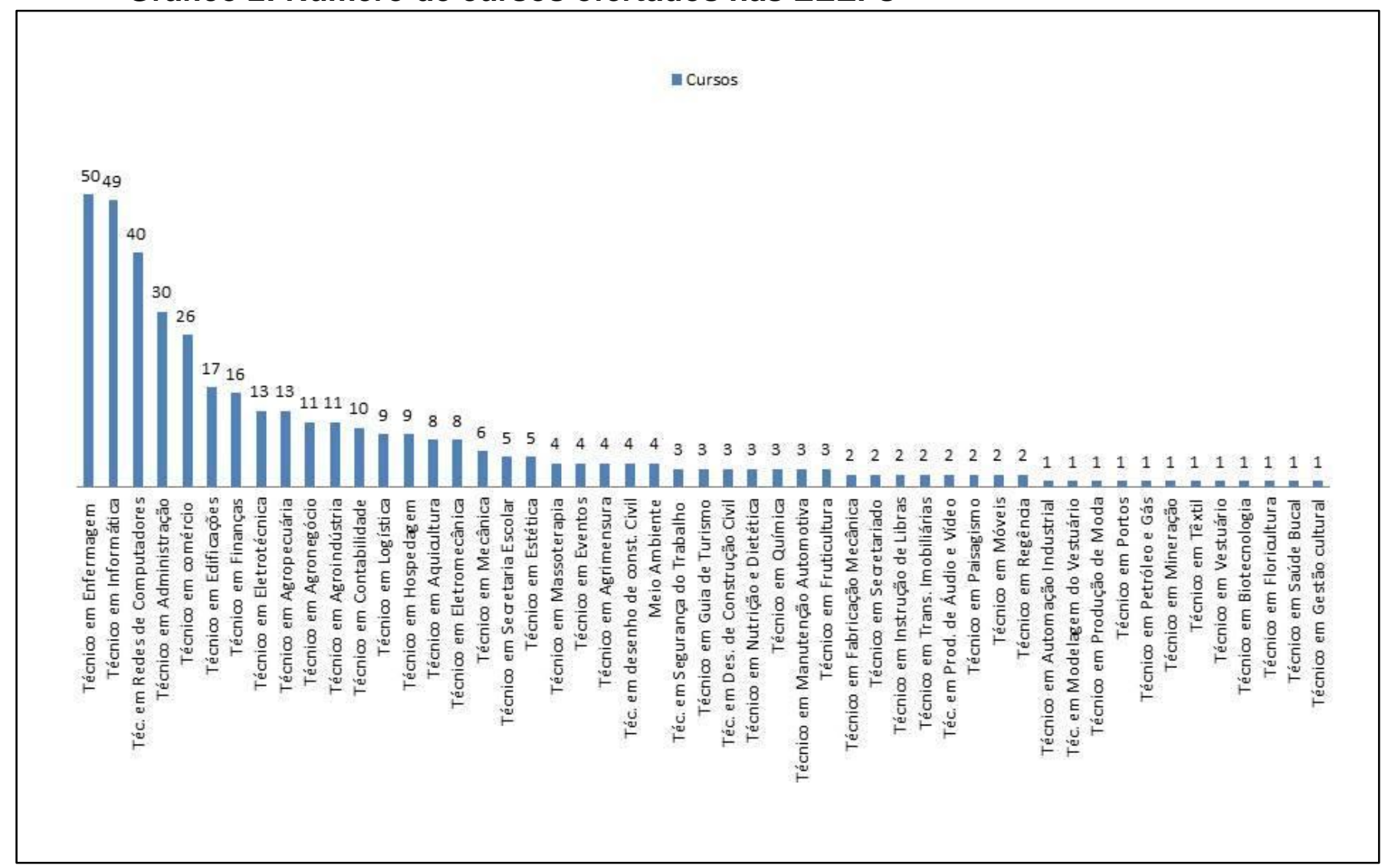

Fonte: Moraes, Jacqueline, 2017.

A análise do gráfico 2 suscita alguns questionamentos que surgiram no âmbito da pesquisa, os quais foram indagados nas entrevistas concedidas pelo exgovernador e pela atual secretária de educação profissional.

Perguntou-se para a secretária de onde havia decorrido a "necessidade" de proporcionar a EPMI (Decreto 30.865 de 03 de abril de 2012). "São as demandas locais, de mercado de educação profissional que fez com que a se oferte os cursos que hoje as escolas têm". 
Também se questionou os estudos e levantamentos sobre as características dos municípios. No caso, ouviu-se as solicitações da comunidade de cada cidade que acolheu essas escolas?

"Não sei bem afirmar como foram feitos, mas foram feitos esses estudos. $\mathrm{O}$ IPECE contribuiu pra isso".

Sobre as solicitações das comunidades dos locais que abrigam as escolas a secretária de educação profissional diz:

a escola hoje [...] já tá firmada nessa comunidade e a gente escuta muito as reinvindicações. Elas fazem hoje essas mudanças de acordo com a demanda do mercado local, né que eles estão mais próximos e na medida do possível, que a gente vai procurando entender o porquê da solicitação e vamos atender.

Acontece que essas solicitações realmente são vistas e pensadas num contexto econômico em que, a partir do já existente nas localidades, ofertam-se os cursos. E aquilo que poderia ser criado, a partir da escola para a localidade, não se leva em consideração, ou seja, não se pensa em como a escola poderia potencializar outras atividades, a partir de alternativas criativas e criadoras.

Ainda durante a entrevista, questionou-se sobre os projetos do governo estadual no que se refere ao desenvolvimento econômico e produtivo do Ceará, e sua relação com as escolas.

A secretária citou o PIFORAR (Projeto de Apoio ao Crescimento Econômico com Redução das Desigualdades e Sustentabilidade Ambiental do Estado do Ceará - Programa para Resultados (PforR) - Missões do Banco Mundial ao Ceará). "Esse projeto vem dando esse apoio pensando no desenvolvimento econômico, local, regional, num planejamento macro.

Mas, há um investimento alto, e se pretende que tenha um retorno, que esses meninos estejam inseridos no mercado de trabalho e isso é até uma inquietação nossa que a gente não consegue também mensurar, porque os meninos eles saem da escola e no primeiro ano a gente ainda consegue identificar aqueles que ainda ficam desempregados, os que trabalham e entram na Universidade, mas ao longo do tempo a gente vai perdendo esse contato porque os meninos vão embora né, dão encaminhamento aos seus projetos de vida e a gente não consegue ter mais esse contato [...]. É interesse do governo que esse investimento repercuta no mercado né, que aumentem a empregabilidade desses meninos, que tirem eles, daqueles estereótipos dos meninos que nem estudam e quem nem 
trabalham. Assim e claro que a nossa intenção é que isso repercuta no mundo do trabalho.

Além desse projeto, as EEPs têm assistência do Instituto Aliança que desenvolveu o currículo da base diversificada. Esse instituto presta assessoria do projeto de vida, do trabalho, e estrutura o currículo para que se trabalhe a formação do professor e do aluno. No contexto da formação, o SEBRAE realiza a formação continuada dos professores que ministram empreendedorismo na escola. Há uma parceria recentemente feita com o Instituto Airton Sena, além do Instituto Natura, que presta assessoria na educação de tempo integral.

Vê-se que há uma influência do modo de pensar das empresas que se transfere para o ensino, isso se dá no plano de uma psicoesfera ${ }^{76}$, que impede uma reflexão mais aprofundada das consequências desses usos do território. "Pois apoia, acompanha e por vezes antecede a expansão do meio técnico-cientifico, visto que a mesma consolida a base técnica e a adequação comportamental a interação moderna entre tecnologia e valores sociais" (RIBEIRO, apud SANTOS, 2012, p.256).

Por outro lado, não se pode deixar de destacar a importância dessas escolas no âmbito socioespacial, como os bons índices de aprovação, a permanência dos alunos, a assiduidade, as aprovações no ENEM e nos vestibulares, dentre outros.

Destaca-se que há um esforço em conduzir essa modalidade para uma formação humana, através da grade diversificada que a integralidade oferece. Esse é o grande diferencial da Educação Profissional.

Segunda a secretária de educação, o grande diferencial dessas escolas

é proporcionar ao aluno optar por uma formação técnica e dá prosseguimento aos estudos e fazer essa concomitância de trabalhar e estudar, e ser um cidadão que participa das transformações sociais do seu lugar que é esse o grande diferencial da Educação Profissional nossa, do Estado do Ceará. Eles têm várias vertentes de trabalhar nosso projeto dentro da nossa matriz curricular. Eles têm aula de formação cidadã, de projeto de vida, tem espaço no tempo pedagógico deles para desenvolver espaços interdisciplinares.

O Ceará, nesse sentido, tem demonstrado que há outros caminhos para a educação, e que é possível haver uma escola pública de qualidade. Esse é um fator

\footnotetext{
${ }^{76}$ Milton Santos define a psicoesfera como 'o reino das ideias, crenças paixões e lugar da produção de um sentido. Faz parte desse meio atual e fornece regras a racionalidade ou estimulando o imaginário.
} 
positivo, um bom começo para se pensar em políticas que possam (re)significar o ensino, e fazer com que esse possa contribuir para despertar outras formas de uso do território, onde se leve em conta as pessoas.

Em entrevista, a coordenadora demonstra uma preocupação com as questões sociais, e ressalta que a escola precisa ser espaço dessas discussões.

Não é a formação técnica de base comum. Não é a formação acadêmica, isso aí todo mundo já precisa ter. Isso é que o mundo tá precisando [...]. Quando tiver bons cidadãos, bons profissionais que tenha compaixão. Se ele não tiver caridade, humanidade em primeiro lugar para fazer bem aquilo que ele se pretender fazer, o mundo nunca vai ser diferente (Entrevista concedida no dia 22 de Junho de 2107).

Há por parte de sua gestão uma preocupação com as questões sociais principalmente quando ressalta que a escola precisa ser espaço dessas discussões.

Höfling, (2001, P 40), concorda com esse pensamento, quando se refere à responsabilidade das ações públicas articuladas com as demandas da sociedade, em que essa deveria, mais do que oferecer "serviços" sociais - entre eles a educação - se voltar para a construção de direitos sociais (HÖFLING, 2001, P 40), para um modo de vida que fortaleça as horizontalidades e possa proporcionar um empoderamento social e econômico, a partir das localidades. Mas como isso é possível?

Visto que, embora existam as demandas do espaço banal, pelas próprias necessidades de usar o território, o que prevalece são as funções subordinadas ao jogo político, comandado pelos agentes hegemônicos, que "ora concorrem com o poder do Estado, ora o têm como aliado para a realização dos seus interesses"? (ALMEIDA, 2008, p. 392).

No contexto atual, esse modelo é produto de uma extrema alienação - provocada pelas forças hegemônicas - dos sujeitos em relação ao trabalho e ao produto do trabalho. Em uma transcrição geográfica, pode-se dizer que isso significa a produção de um território alienado [...] (ZOMIGHANI JÚNIOR, 2013, p. 338-339). 
Portanto, outras possibilidades de gerir o território usado são suprimidas em função de uma força centrífuga ${ }^{77}$, fortalecida por um discurso hegemônico que faz com que isso pareça inevitável.

Acontece que, como Santos diz, o mundo é visto como possibilidades. A partir desse concepção, é possível implementar uma política diferente da que hoje impera. Ou seja, utilizar-se do conhecimento, da técnica e da informação para propor formas de viver que congreguem a todos, de modo que as desigualdades possam cada vez mais diminuir ou até mesmo desaparecer.

Sobre esse aspecto, Santos (1999) discute a noção de lugar, onde este está ligado à resistência, à força que se materializa localmente, ocorrendo embates entre o local e o global, assim a construção dos lugares sofre forças externas, existindo ainda a manifestação de elementos novos e velhos, a cada momento observados.

Diante dessa afirmação, é pertinente discorrer que, nos últimos anos, devido ao processo de globalização, o estudo do lugar parece tomar mais força. $\mathrm{Na}$ concepção de Souza (2004, p.2), em palestra no Seminário sobre Política Municipal realizado na Universidade Estadual Vale do Acaraú, no dia 30 de agosto de 2004, a partir dos lugares, se pode conceber estratégias e ações de toda ordem. Isso significa que, no mundo do presente, com os recursos tecnológicos disponíveis, é possível, sem sair do lugar, realizar uma série de tarefas e serviços, estes afetados pelo chamado processo da globalização, que Milton Santos chamou de meio técnico-científico-informacional, que une o Lugar ao mundo, atribuindo assim, para Sobral, uma dimensão importante. Na afirmação de Souza (2004), na mesma

\footnotetext{
${ }^{77}$ Milton Santos em seu texto "O retorno do Território" aborda a influência de um comando imposto de fora, hierárquico, que se utiliza de informações privilegiadas e se traduz num poder sobre os usos do território. Assim, discorre sobre o acontecer solidário e o subdivide em três: acontecer homólogo, complementar e hierárquico. "O acontecer homólogo é aquele das áreas de produção agrícola ou urbana, que se modernizam mediante uma informação especializada e levam os comportamentos a uma racionalidade presidida por essa mesma informação que cria uma similitude de atividades, gerando contiguidades funcionais que dão os contornos da área assim definido. $O$ acontecer complementar é aquele das relações entre cidade e campo e das relações entre cidades, consequência igualmente de necessidades modernas da produção e do intercâmbio geograficamente próximo. Finalmente, o acontecer hierárquico é um dos resultados da tendência à racionalização das atividades e se faz sob um comando, uma organização, que tendem a ser concentrados e nos obrigam a pensar na produção desse comando, dessa direção, que também contribuem à produção de um sentido, impresso na vida dos homens e na vida do espaço" (SANTOS, 2005, p.257).
} 
palestra: é o lugar que sofre todos os impactos da globalização. (Informação verbal) ${ }^{78}$

Portanto, há várias outras maneiras de conduzir a educação, para que esta possa vislumbrar usos do território pensados a partir do espaço banal, do espaço de todos; o que irá ser discutido a seguir, a partir dos usos do território em algumas cidades das 7 mesorregiões cearenses (Mapa 9).

${ }^{78}$ Notícia fornecida por Jornal Expresso do Norte, Sobral, 4 setembro 2004. 


\section{Mapa 11: Mesorregiões do Ceará}

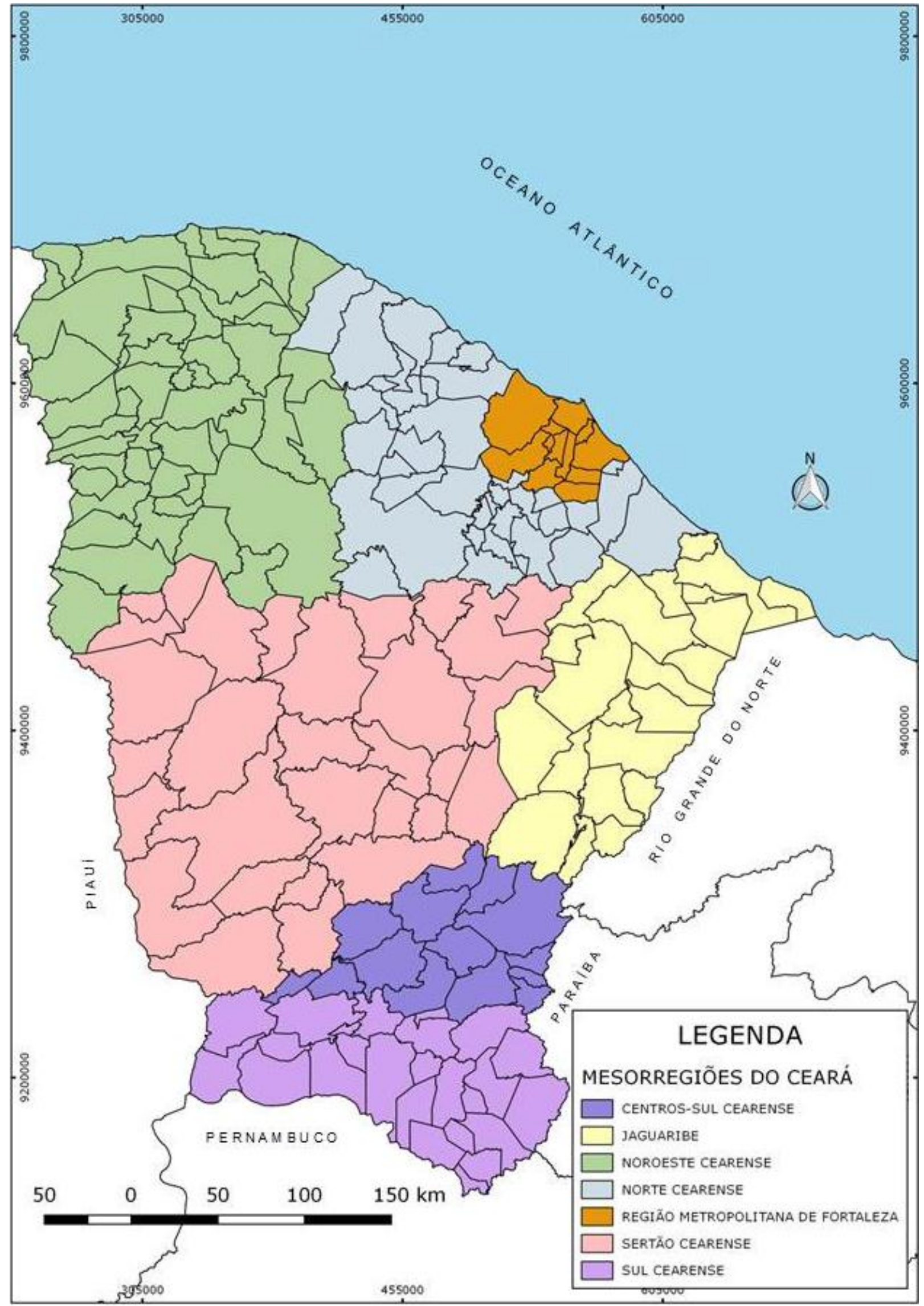




\section{A perspectiva geográfica sobre educação}

É deveras difícil pensar, propor ou definir um modelo de educação ideal para a sociedade do meio-técnico-científico-informacional, até porque os conhecimentos repassados no âmbito das instituições educacionais, muitas vezes, são utilizados para manter no poder uma classe social em detrimento de outra (FOUCAULT, 1971).

Mas aqui se ousou propor, a partir da geografia, outras possibilidades para se pensar na condução do Ensino Profissional Técnico Integrado de Nível Médio. Além de se defender uma base que privilegie a formação humanística.

No caso do Ceará, uma outra perspectiva educacional exigirá um maior conhecimento dos territórios dos pequenos municípios, para desenvolver, no contexto das políticas educacionais, ações voltadas para uma educação com resultados concretos, no sentido de levar em conta a realidade dessas localidades.

O Ceará, no contexto das políticas Educacionais, tem feito um esforço na busca de alternativas para melhorar a sua educação. No âmbito da Educação Técnica, é um dos estados que se destaca nesta modalidade de ensino. Para o exgovernador Cid Ferreira Gomes (governador que vislumbrou e implantou as EEEPs no Ceará), em entrevista, relata que a opção dessa modalidade de ensino visava, sobretudo, a melhoria da qualidade da educação de nível médio, já que essa etapa apresentava muitos problemas, como evasão, reprovação, baixos índices e baixa qualidade no ensino/aprendizagem.

Em sua fala ressalta:

Escola de Educação Profissional é parte de uma estratégia que a gente procurou implantar no Estado para melhorar a qualidade da educação pública. Então, eu parto do seguinte princípio. As pessoas são diferentes, o que pode assegurar o mínimo de oportunidade para as pessoas é o Estado, eu digo o Estado, eu estou falando o ente público, federal, estadual e municipal se esforçar para dar oportunidades iguais para as pessoas. As pessoas continuarão sendo diferentes, cada um com o seu talento, cada um com sua vocação, mas creio que é obrigação do poder público dar as pessoas dois direitos básicos que eu traduziria em saúde que é o direito a vida e educação que é o direito a oportunidades iguais, essas duas tarefas são intransferíveis [...]. ai já entra um componente ideológico, de estado mínimo, principalmente em um País de desigualdade como o nosso, não acredito que o mercado vai resolver os problemas, não irá nunca resolver os problemas, então em acredito em um Estado forte com poupança, com capacidade de 
investimento, investir principalmente nessas duas áreas, que assegura 0 direito a vida e assegura o direito as oportunidades iguais.

Ainda destaca a formação técnica no estado do Ceará.

na nossa formação, nós não chegamos a 3\% de uma população de nível superior, e em relação de nível superior para nível técnico, pasmem! É de 1 para $1 / 2 \%$. Nós temos menos profissionais de nível técnico de formação técnica do que profissionais de nível superior que já temos poucos, então tá errado essa coisa.

Esse dado é percebido na constituição do uso do território, como já discutido na primeira parte da tese. Outro fator importante é a própria configuração territorial ${ }^{79}$ a partir desses usos, a qual impõe uma refuncionalização espacial, visto que os novos objetos irão demandar novas especializações. Por exemplo, um objeto geográfico, como um porto, induz a criação de novos objetos e cria novas profissões e especializações, estas, por sua vez, recriam outras, e assim sucessivamente.

Pode-se verificar essa informação a partir da fala do técnico que nos concedeu entrevista, onde afirma que, no porto, houve um acréscimo por demandas de mão de obra especializada, e que esta veio de outras regiões como sul e sudeste, o que muitas vezes torna oneroso e dispendioso. Portanto, a expectativa é fomentar cada vez mais esses mercados e formar esses profissionais para atender essas demandas.

Vê-se que a incidência e a força do mercado se sobrepõem, inclusive ideologicamente; o que se percebe quando os próprios agentes que usam esse serviço tem preferência por determinados cursos.

Assim, os investimentos são focados nesses setores empresariais de grande alcance mercadológico, e são implementados por meio de políticas voltadas para investir no fortalecimento dessa política, seja por meio de concessões dadas pelo Estado, seja por propagandas ou iniciativas de agências, como as feitas pela

\footnotetext{
${ }^{79}$ São os meios de ação cristalizados (Durkheim) que podem ser considerados como equivalentes ao "trabalho morto" (Marx) representado em nossos dias, pelo conjunto de objetos culturais que, ao lado ou no lugar dos objetos "naturais", cuja significação modificam, formam o que podemos chamar de configuração espacial, configuração territorial ou configuração geográfica, da qual a paisagem é um aspecto, uma fração (SANTOS, 1996, p.61).
} 
$A D E C E^{80}$, em que a mesma busca parcerias e investimentos financeiros e Parcerias Público-Privadas (PPPs) por empresas nacionais e internacionais no Ceará, seja pela oferta de uma mão de obra especializada, flexível e enérgica, que cresce exponencialmente.

É o processo da globalização que acaba, direta e indiretamente influenciando aspectos da existência: da vida econômica, cultural, das relações interpessoais e da própria subjetividade (SANTOS, 2008).

Nesse contexto as EEEPs também servem como meio para atrair grandes investimentos, pois há imposições no âmbito social que obedecem a uma gama de regulamentações e se fazem presente no território usado conforme aumenta a densidade da técnica no espaço geográfico.

Por vezes essas regulamentações limitam a capacidade de outros modos de conduzir a educação, visando um caminho alternativo de projeto social.

A comunicação e as trocas, tão significativas, são de certo modo substituídas por políticas cada vez mais vinculadas ao modelo desenvolvimentista e arcaico, que insiste em se fazer presente, mesmo quando esse é tão criticado.

Neste aspecto, Friedman, em seu livro "7 estudos sobre o homem e a tecnica", fala da percepção no novo meio, que

parece marchar cada vez mais na direção dos elementos que representam diretamente as coisas do mundo inanimado e animado, as manifestações naturais da vida, para significar uma rede crescente de seres fabricados, e por isso, de reações mecânicas e enérgicas (FRIEDMAN, 1968, p. 48).

Em muitas circunstâncias, as técnicas multiplicadas no meio-tecnicocientífico-informacional tendem a tornar mais rara a percepção dos modos de uso do território, dada a velocidade e o modo que as mesmas se propagam. No entanto,, esta também não estará anulada.

\footnotetext{
${ }^{80}$ A Agência de Desenvolvimento do Estado do Ceará (Adece) foi criada pelo Governo do Estado do Ceará com a finalidade de executar as políticas e diretrizes oriundas da Secretaria do Desenvolvimento Econômico (SDE). Tem por finalidade, dentre outras, executar políticas de desenvolvimento econômico, industrial, comercial, de serviços, agropecuário e de base tecnológica, articulando-se com os setores produtivos e atraindo e incentivando investimentos, além de criar condições para a competitividade dos setores econômicos do Estado do Ceará (CEARÁ, 2015). Disponível em: http://www.adece.ce.gov.br/index.php/sobre-a-adece.
} 
Sem dúvida, o mercado vai impondo, com maior ou menor força, aqui e ali, elementos mais ou menos maciços da cultura de massa, indispensável, como ela é, ao reino do mercado, e a expansão paralela das formas de globalização econômica, financeira, técnica e cultural. Essa conquista, mais ou menos eficaz segundo os lugares e as sociedades, jamais é completa, pois encontra a resistência da cultura preexistente. (SANTOS, 2008, p. 143-144).

Portanto, retoma-se o detour, ou seja, um possível desvio para pensar o projeto dessas escolas a partir da criação de demandas que possam vir a potencializar outros usos do território.

Milton Santos, em seu livro "Por uma outra globalização", apresenta subsídios para se pensar alternativas para uma nova sociedade, tomando como ponto partida a prática da vida e a existência de todos (SANTOS, 2008, p. 148).

Assim diz Santos (2008, p. 148):

A nova paisagem social resultaria do abandono e da superação do modelo atual e sua substituição por um outro, capaz de garantir para o maior número a satisfação das necessidades essenciais a uma vida humana e digna, relegando a uma posição secundária necessidades fabricadas, impostas por meio da publicidade e do consumo conspícuo. Assim o interesse social suplantaria a atual precedência do interesse econômico e tanto levaria a uma nova agenda de investimentos como uma nova hierarquia de gastos públicos, empresariais e privados. Tal esquema conduziria, paralelamente, ao estabelecimento de novas relações internacionais.

Essa forma de prover a existência de modo digno, propiciando a satisfação das necessidades essenciais da vida, requer uma transformação nos modos de pensar e agir, ou seja, a elaboração de políticas para a efetivação das mesmas. Isso acarretaria paulatinamente em novas formas de pensar, pois os fundamentos da vida mental acabam por serem atingidos por mudanças de meio (FRIEDMAN, 1968, p. 52).

A educação é a maneira mais adequada de tornar isso efetivo, pois esta "produz, ativa e intencionalmente, em cada indivíduo singular, a humanidade que é produzida histórica e coletivamente pelo conjunto dos homens". Portanto ela é um dos meios mais eficazes para a transmissão e o aprendizado das técnicas culturais, de uso, produção e comportamentos. (DEMERVAL SAVIANI, 2000, p. 17). 
Neste sentido, Milton Santos já afirmara que um sistema pode mudar quando seus elementos, parcialmente ou em conjunto, lentamente ou de uma só vez, são transformados. Se, nas condições atuais, as inovações são inevitáveis (muitas vezes bem vindas), é preciso constituir uma nova política de uso dos sistemas técnicos (ZOMIGHANNI JÚNIOR, 2013, 341).

\section{Outras possibilidades e outros usos possíveis e necessários, do território cearense?}

Tomando-se como ponto de partida o projeto para essas escolas, e tendo em vista as potencialidades que as mesmas têm apresentado, a crítica é pertinente no sentido de uma análise mais aprofundada sobre o que poderia e deveria também ser levado em conta.

Quer dizer, que outras características e/ou potencialidades poderiam ser exploradas? Que alternativas há para repensar a EEEPs, para que estas possam vir a contribuir e potencializar outras formas de usar o território de modo que as horizontalidades sejam fortalecidas? E ainda, qual o modelo de ensino técnico que o Ceará precisa ou quer para viabilizar seu projeto de futuro?

Ousa-se aqui arriscar algumas proposições na busca de uma possível aplicabilidade de alternativas para as EEEPs.

"A proposta inicial é de participar deste debate a partir da produção do conhecimento geográfico, possibilitando discutir a prática política" (ZOMIGHANNI, 2013, p. 336-337), a partir da compreensão do uso do território, da leitura espacial e daquilo que se identificou de potencial, e que pode ser desenvolvido nas localidades que abrigam as EEEPs.

Tais proposições foram pensadas e formuladas a partir de análises feitas durante a pesquisa de campo em várias cidades do estado.

Parte-se também da reflexão sobre o lugar, como espaço da existência e da coexistência (SARTRE apud SOUZA, 2005, p. 253). Do lugar/mundo como um par indissociável, que recebe as mudanças que se processam no mundo pelo uso da técnica, da ciência e da informação. O lugar no qual incide certo controle dos agentes hegemônicos, mas também, onde "reside a única possibilidade de 
resistência aos seus processos perversos, dada a possibilidade real e efetiva da comunicação, logo da troca de informação, logo da construção política" (SOUZA, 2005, p. 253).

"A mesma materialidade, atualmente utilizada para construir um mundo confuso e perverso, pode vir a ser uma condição da construção de um mundo mais humano" (SANTOS, 2008, p. 174).

Portanto, ressalta-se que, no âmbito socioeconômico, várias localidades apresentam características e valor cultural muito forte, porém pouco exploradas ou aproveitadas para fortalecer as horizontalidades e gerar qualidade de vida para as pessoas.

Nesse sentido, apresenta-se essa reflexão a partir da percepção dos usos do território em alguns municípios das 7 mesorregiões cearenses. A começar por algumas cidades da mesorregião denominada Noroeste Cearense (Mapa 10: Cidades da Mesorregião Noroeste Cearense: usos pelas EEEPs e potencialidades), como Viçosa do Ceará ${ }^{81}$ e Sobral ${ }^{82}$; tombadas pelo IPHAN como patrimônio histórico nacional, por apresentarem um conjunto urbano arquitetônico de grande valor cultural.

\footnotetext{
${ }^{81}$ Viçosa do Ceará localizada na microrregião da lbiapaba, noroeste cearense, distante $344 \mathrm{~km}$ da capital Fortaleza é considerada pelo IPHAN uma das mais importantes vilas de índios do Brasil dos séculos XVII e XVIII, e em agosto de 2003, passou a ser considerada "patrimônio nacional" (ALVES, 2016).

${ }^{82}$ Sobral está localizada no Norte do Estado do Ceará, distante $230 \mathrm{~km}$ da capital, tem origens que remontam o primeiro quartel do século XVIII. Em agosto de 1999, teve seu centro histórico tombado como Patrimônio Nacional pelo IPHAN, através da iniciativa do Instituto do Patrimônio Histórico e Artístico Nacional - IPHAN, elaborado por sua 4a Superintendência Regional. O conjunto arquitetônico e urbanístico de Sobral, tombado pelo Iphan em 2000, abrange uma área que se estende da margem do rio Acaraú à Rua Coronel Monte Alverne, onde estão inúmeros imóveis e espaços públicos. Dentre suas valiosas edificações remanescentes do século XVIII, estão o Teatro e a Praça São João, um conjunto de casas em estilo art noveau, sobrados decorados com motivos greco-romanos e várias construções religiosas, como as igrejas da Sé e dos Pretinhos de Nossa Sra. do Rosário (construída por escravos). Com uma forte capacidade de autogestão, se destaca pelos índices no ensino fundamental, e tem uma economia forte que se interliga ao ensino superior,
} 
Mapa 12: Cidades da Mesorregião Noroeste Cearense: usos pelas EEEPs e potencialidades

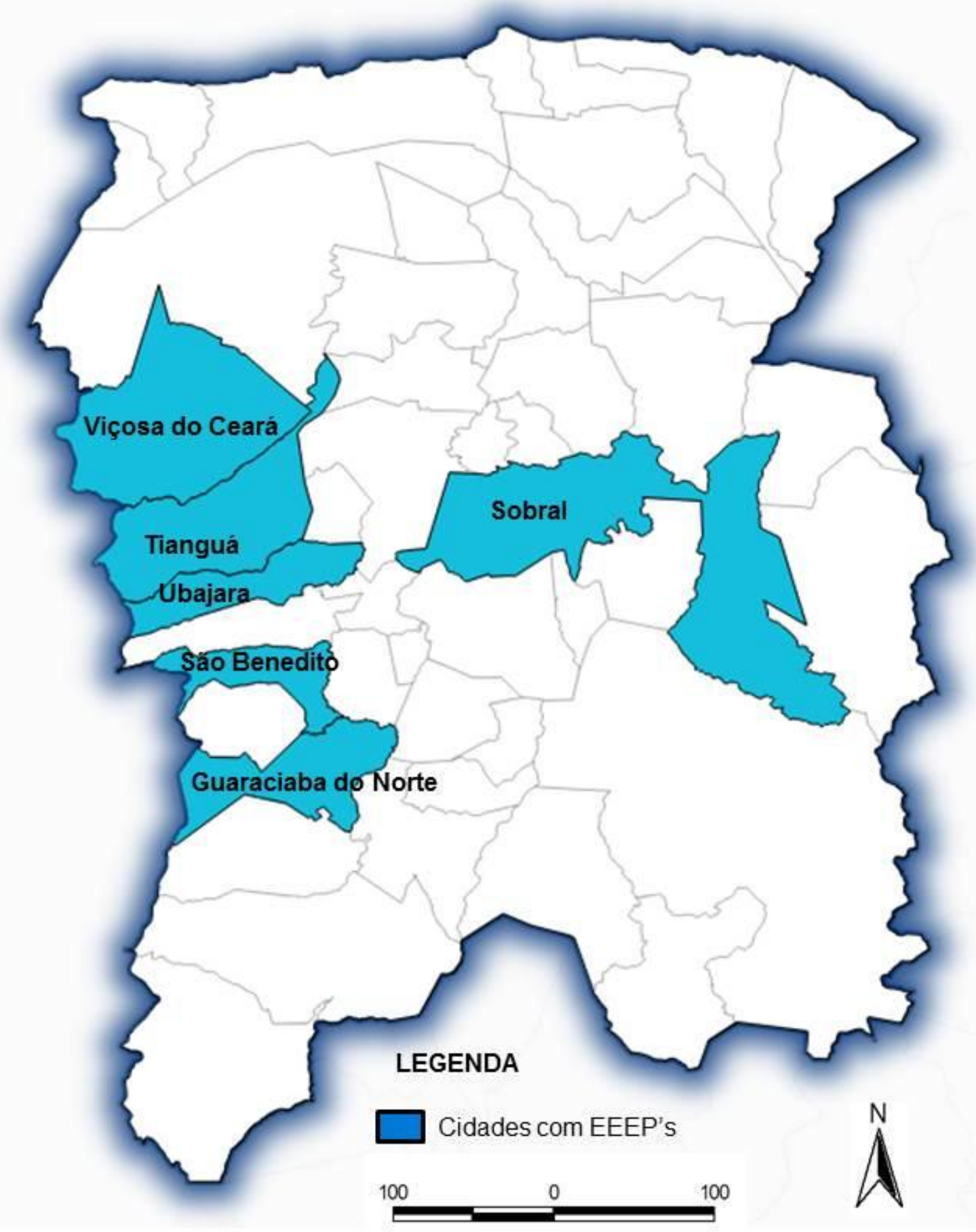

Elaboração: Maria do Carmo Alves/Manoel Guedes 
Essas cidades "por meio dos seus sítios tombados, exibem concretamente na paisagem testemunhos do período colonial" (ALVES, 2016, 144);0 que atribui às mesmas uma importância histórica que se traduz ainda hoje nas suas constituições (Fotos 17 e 18).

\section{Foto 17: Igreja do Céu - Viçosa do Ceará}

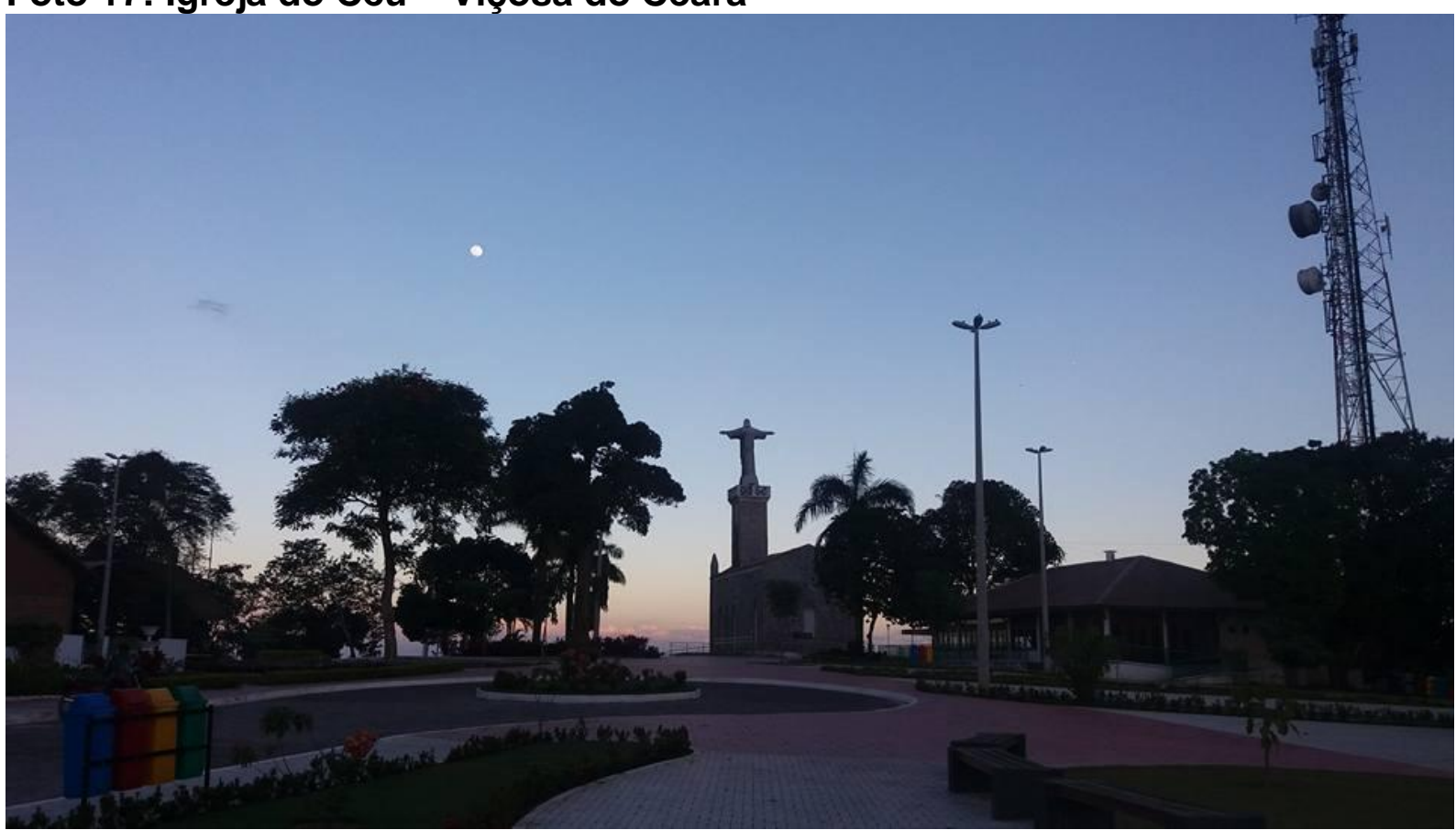

Fonte: Moraes, 2017. 
Foto 18: Sobral/Ceará

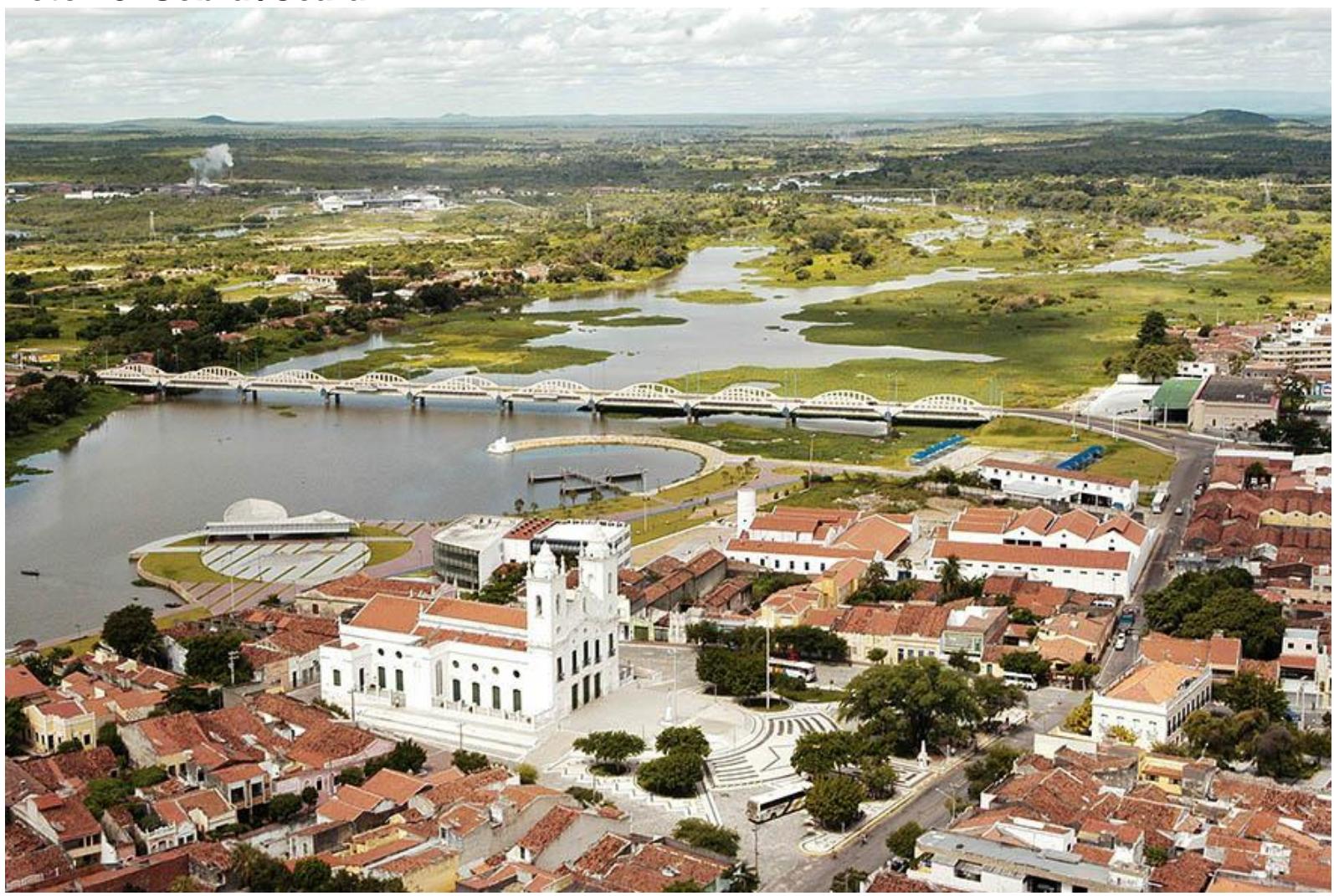

Fonte: https://www.flickr.com/photos/42308524@N03/6418603279/lightbox/

Em sua tese, intitulada USOS DO TERRITÓRIO E RUGOSIDADES: Fundamentos Socioespaciais do Patrimônio Histórico do Estado do Ceará, Alves (2016) discute, a partir do tombamento dessas cidades, as contradições entre preservação e mercantilização ${ }^{83}$. Sobre isso, ele diz: "Essas cidades são pouco conhecidas em nível nacional, e não apresentam no seu sítio uma dinâmica econômica ou mesmo um investimento capaz de mover o turismo, se comparadas a outras cidades como as mineiras ou as baianas" (ALVES, 2016, p. 147).

Nesse contexto, acredita-se que a oferta ou mesmo a elaboração de cursos técnicos que pudessem abranger, em seus componentes curriculares, a história, 0 patrimônio e a geografia das cidades, poderiam ser aproveitados para aumentar as solidariedades numa perspectiva mais horizontal, que favorecesse a dinâmica pelo

\footnotetext{
${ }^{83}$ Nesse contexto, a autora apresenta a rugosidade, - conceito entendido por Santos (2008), como "o que fica do passado como forma, espaço construído, paisagem, o que resta do processo de supressão, acumulação, superposição, com que as coisas se substituem e acumulam em todos os lugares" - como um ponto de partida para entender a dinâmica do patrimônio cearense tombado e alcançar a compreensão do uso do território (ALVES, 2016, p. 61).
} 
comércio e pelos serviços, pois angariaria novas demandas a nível local, e poderiam ampliar ou mesmo construir novos usos.

Outro ponto a ser discutido, no contexto do potencial do Ceará, é a agricultura como horizontalidade, uma vez que existem técnicas e solos favoráveis a essa prática.

$\mathrm{Na}$ mesma mesorregião, mais especificamente nas cidades de Tianguá, Ubajara, São Benedito, Guaraciaba do Norte e Viçosa do Ceará, por exemplo, a agricultura, nos ramos de hortaliças e flores ${ }^{84}$, tem um uso relevante. Mas estes potencializam mais o circuito superior, embora o circuito inferior ${ }^{85}$ se utilize deles, pois há poucas políticas locais para melhor e maior aproveitamento, até mesmo no contexto da formação para essas demandas, no que diz respeito a uma autonomia dos lugares.

\footnotetext{
${ }^{84}$ A região da lbiapaba é a principal no abastecimento de flores para a capital se comparado com as outras regiões produtoras do estado (Cariri, Maciço de Baturité, Região Metropolitana, Vales do Curu e Aracatiaçu), pois possui a maior produção e as principais empresas produtoras de flores, sendo estas: Grupo Reijers, Cearosa, Grupo Swart e Flora. Os municípios produtores de flores e plantas ornamentais no Planalto da Ibiapaba são: Carnaubal, Guaraciaba do Norte, Ibiapina, São Benedito, Tianguá, Ubajara, e Viçosa do Ceará. As principais espécies produzidas são: rosas, folhagens e plantas ornamentais (AGROPOLOS, 2013).

${ }^{85} \mathrm{O}$ circuito superior originou-se diretamente da modernização tecnológica e seus elementos mais representativos hoje são os monopólios e as suas relações ocorre fora da cidade e região que os abrigam e tem por cenário o país ou o exterior. O circuito inferior, formado de atividades de pequena dimensão e interessando principalmente às populações pobres, é, ao contrário, bem enraizado e mantém relações privilegiadas com sua região. (SANTOS, 2008, p. 22).
} 
Foto 19: Fazenda de flores - Reijers: São Benedito/CE.

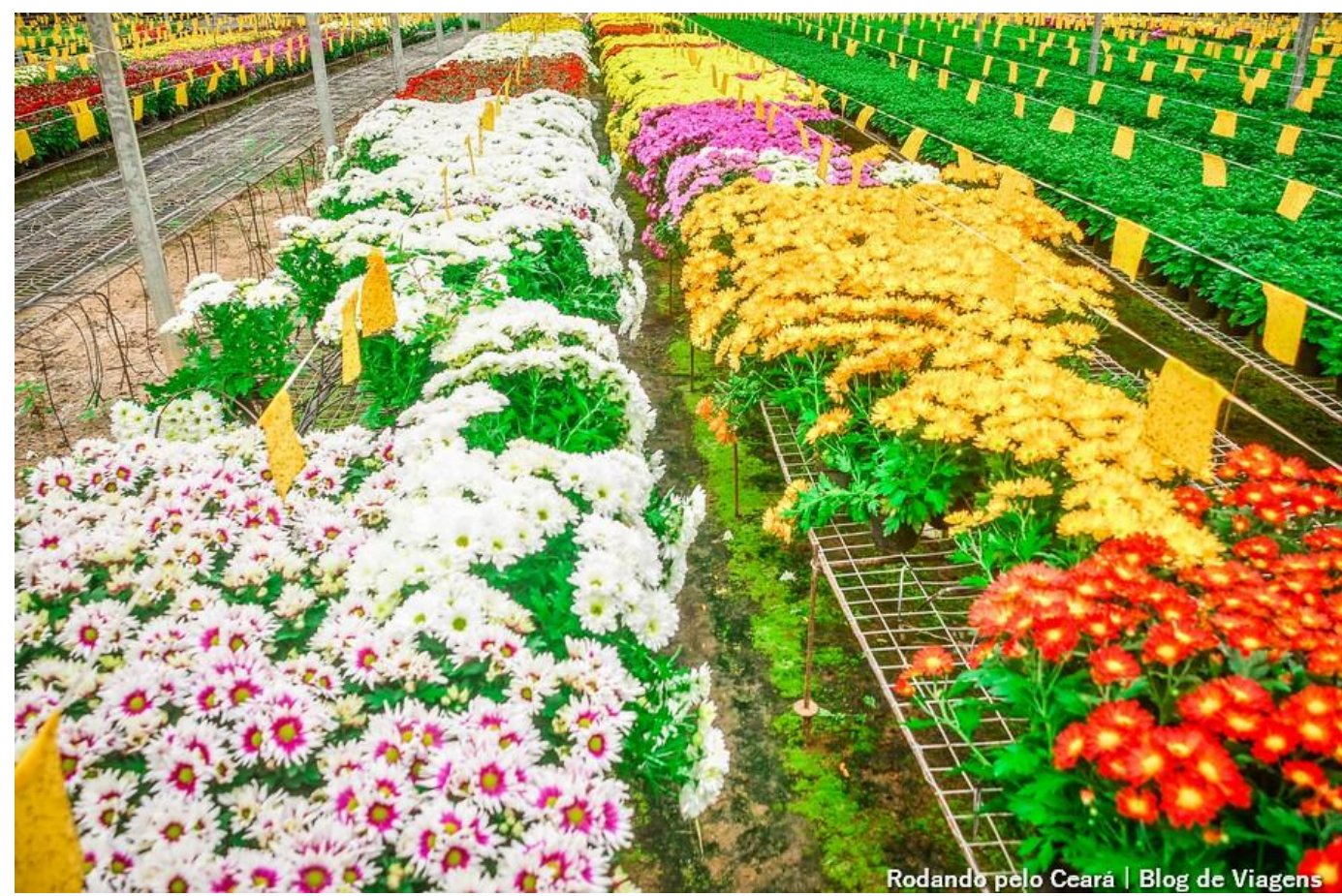

Fonte: http://www.rodandopeloceara.com.br/2016/02/caminho-das-flores-uma-visitareijers.html, 2016.

Foto 20: Fruticultura - Ibiapaba

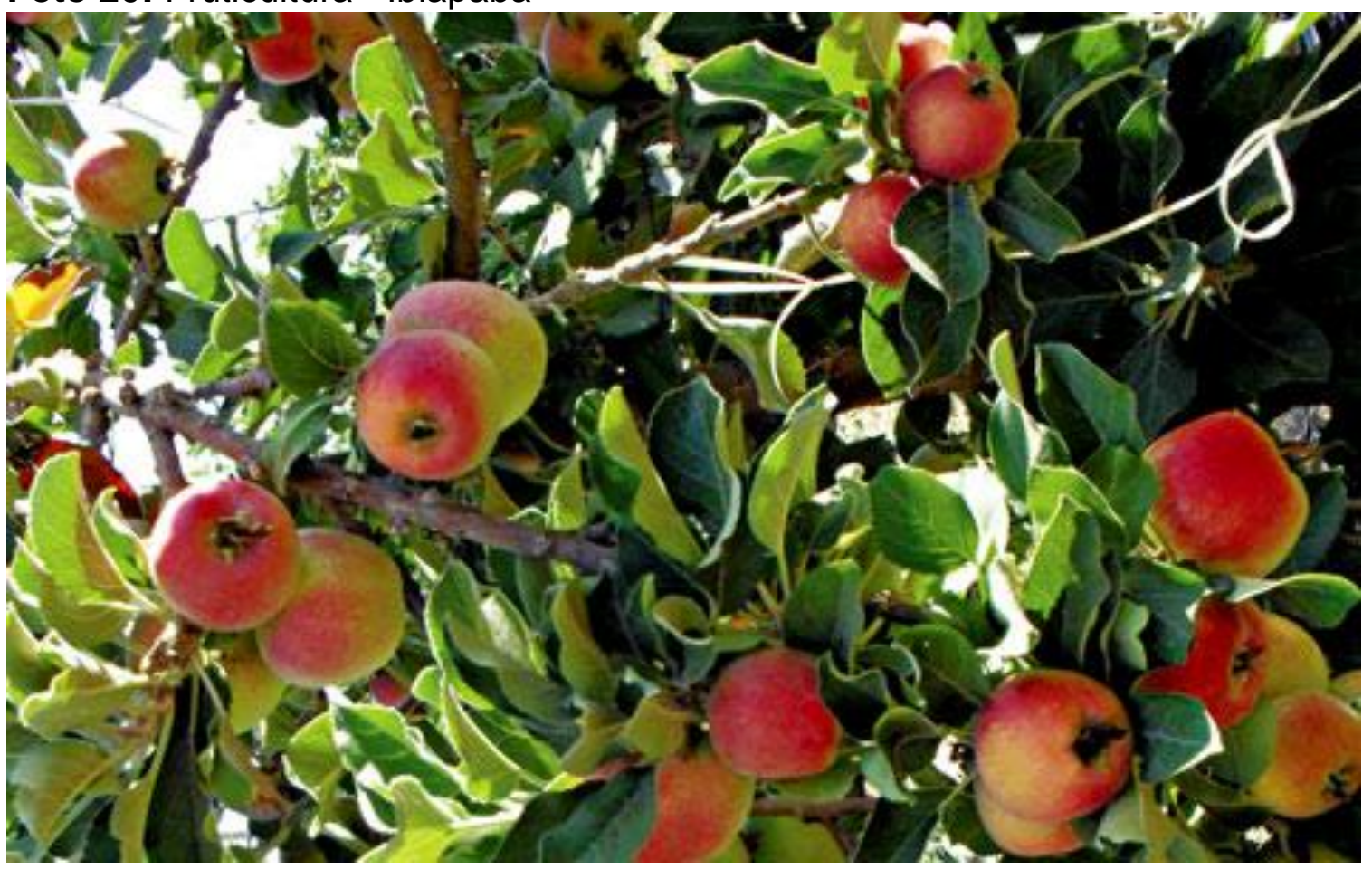

http://blogs.diariodonordeste.com.br/zonanorte/agricultura/cultivo-na-serra-daibiapaba-tem-exito/, 2013. 
Foto 21 e 22: Fruticultura - Ibiapaba
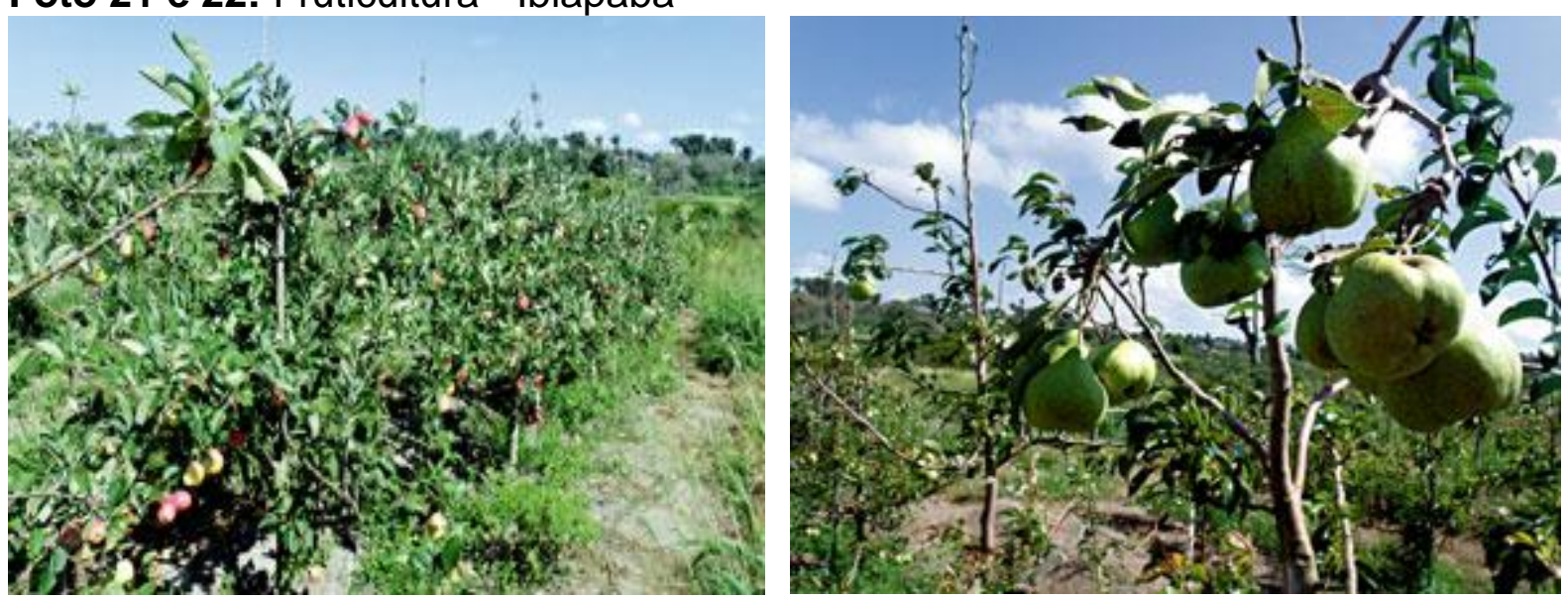

http://blogs.diariodonordeste.com.br/zonanorte/agricultura/cultivo-na-serra-daibiapaba-tem-exito/, 2013.

Embora uma análise dos cursos ofertados apresente um vínculo com essas demandas, - Viçosa do Ceará: Cursos: Técnico em Eletromecânica, Transações imobiliárias, fruticultura, comércio e contabilidade; Sobral: Técnico em Informática, Redes de computadores, Enfermagem, Saúde Bucal, Regência, Manutenção Automotiva, Fabricação Mecânica, Logística; Guaraciaba do Norte: Agricultura (floricultura), finanças, comércio, edificações; São Benedito: Informática, Agronegócio; Tianguá: Agropecuária, contabilidade, comércio e estética; Ubajara: Redes, Informática, Fruticultura, Comércio; - os cursos são mais voltados para uma concepção mercadológica e econômica, e abrem pouco espaço para se pensar projetos para uma maior autogestão local.

Nesse aspecto, sugere-se uma maior autonomia escolar, com inserção de recursos para a elaboração e criação de projetos, no intuito de fortalecer esses setores, em que a própria escola, juntamente com o poder público local e estadual, iria fornecer subsídios, tanto técnicos quanto intelectuais, para gerir tais projetos. 0 empreendedorismo trabalhado se voltaria para dar autonomia aos estudantes, para pensar na criação ou no fortalecimento de demandas, partindo inicialmente do conhecimento geográfico sobre o Ceará e o lugar.

$\mathrm{Na}$ Mesorregião Norte Cearense, pode-se citar, como exemplos, as cidades de Guaramiranga ${ }^{86}$, Redenção ${ }^{87}$, Trairi ${ }^{88}$ (Mapa: Cidades da Mesorregião Norte

\footnotetext{
${ }^{86}$ Localizada no Norte do Estado do Ceará, na região serrana do Maciço de Baturité, a $104 \mathrm{Km}$ de Fortaleza numa altitude de 865 metros (IBGE), Guaramiranga embora não tenha uma EEEp em seu município é uma cidade que apresenta um forte potencial turístico e cultural as quais poderiam atrair outras demandas técnicas.
} 
Cearense: usos e potencialidades). Todas essas cidades, de algum modo, apresentam características que podem induzir a uma gestão mais localizada, e que podem firmar usos no âmbito da sua própria dinâmica.

\section{Mapa 13: Cidades da Mesorregião Norte Cearense: usos do território pelas EEEPs}

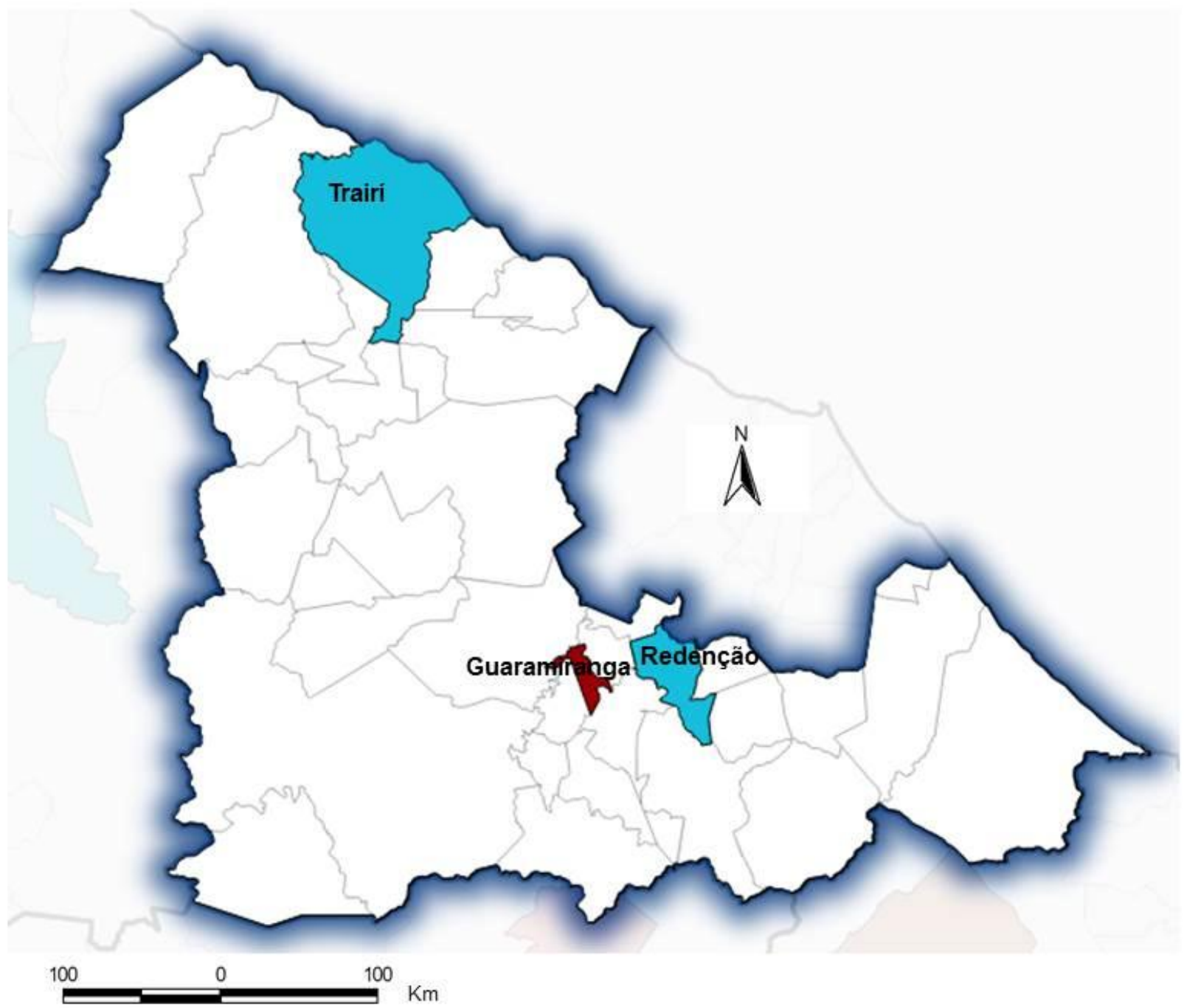

Elaboração cartográfica: Maria do Carmo Alves/Manoel Guedes

${ }^{87}$ Redenção localiza-se a uma altitude de 88 metros acima do nível do mar e a $55 \mathrm{~km}$ de distância de Fortaleza.

${ }^{88}$ Trairi esta localizada a $124 \mathrm{Km}$ de Fortaleza no litoral oeste do estado. Compõem a paisagem litorânea as praias de Guajiru, Flecheiras, Emboaca e Mundaú 
No caso de Guaramiranga, ainda que seja a menor cidade do Ceará em termos de população, sedia um dos maiores festivais do Ceará, o "Festival Jazz e Blues", que se constitui como o evento de maior destaque no calendário festivo da cidade e do estado, seguido pelo Festival Nordestino de Teatro que celebrou, em 2016, sua 23a edição, e que impulsiona o turismo em conjunto com o comércio com seus restaurantes e artesanato local.

\section{Foto 23: Guaramiranga/CE}

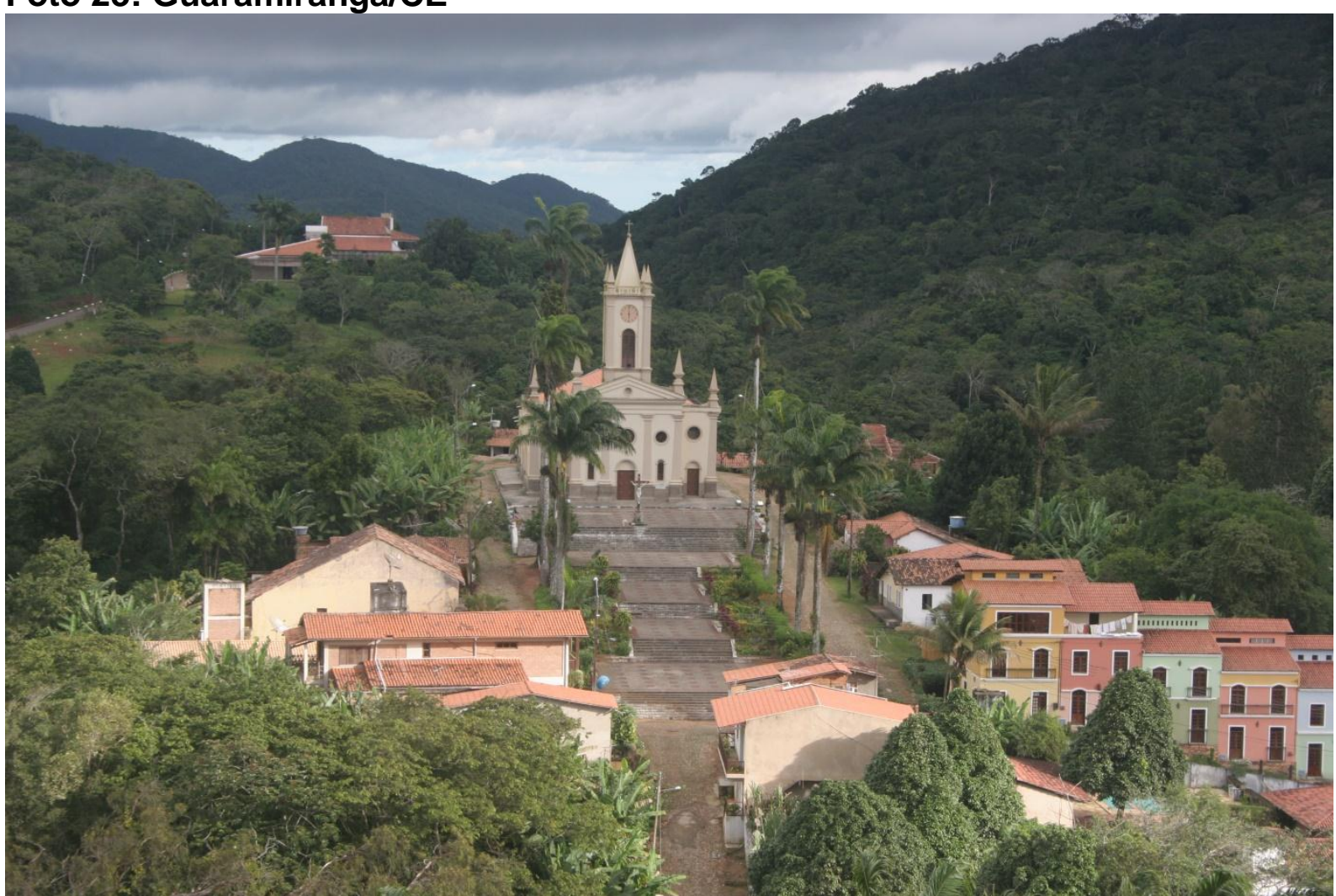

Fonte: http://www.unilab.edu.br/guaramiranga-2/, 2012.

Redenção tem uma importância histórica e geográfica, que é pouco conhecida ou explorada do ponto visto cultural. Essa cidade foi a primeira do Brasil a libertar todos os seus escravos em $1^{\circ}$ de janeiro de 1883. Por esse fato, foi escolhida para abrigar a Universidade da Integração Internacional da Lusofonia AfroBrasileira (UNILAB), a qual visa à integração internacional (UNILAB, 2017).

Essa universidade é voltada aos países da África, sobretudo aos Países Africanos de Língua Oficial Portuguesa (PALOP) Angola, Cabo Verde, GuinéBissau, Moçambique e São Tomé e Príncipe, além da Guiné Equatorial, que adotou o idioma recentemente, mas inclui também Timor-Leste e Macau. 
Compõe também, em sua paisagem, rugosidades caras, no que se refere à constituição histórica do estado, como o Museu Histórico e Memorial da Liberdade ${ }^{89}$, bem como a estrutura conservada de uma Senzala do período da escravidão.

\section{Foto 24: Museu Senzala Negro Liberto - Redenção}

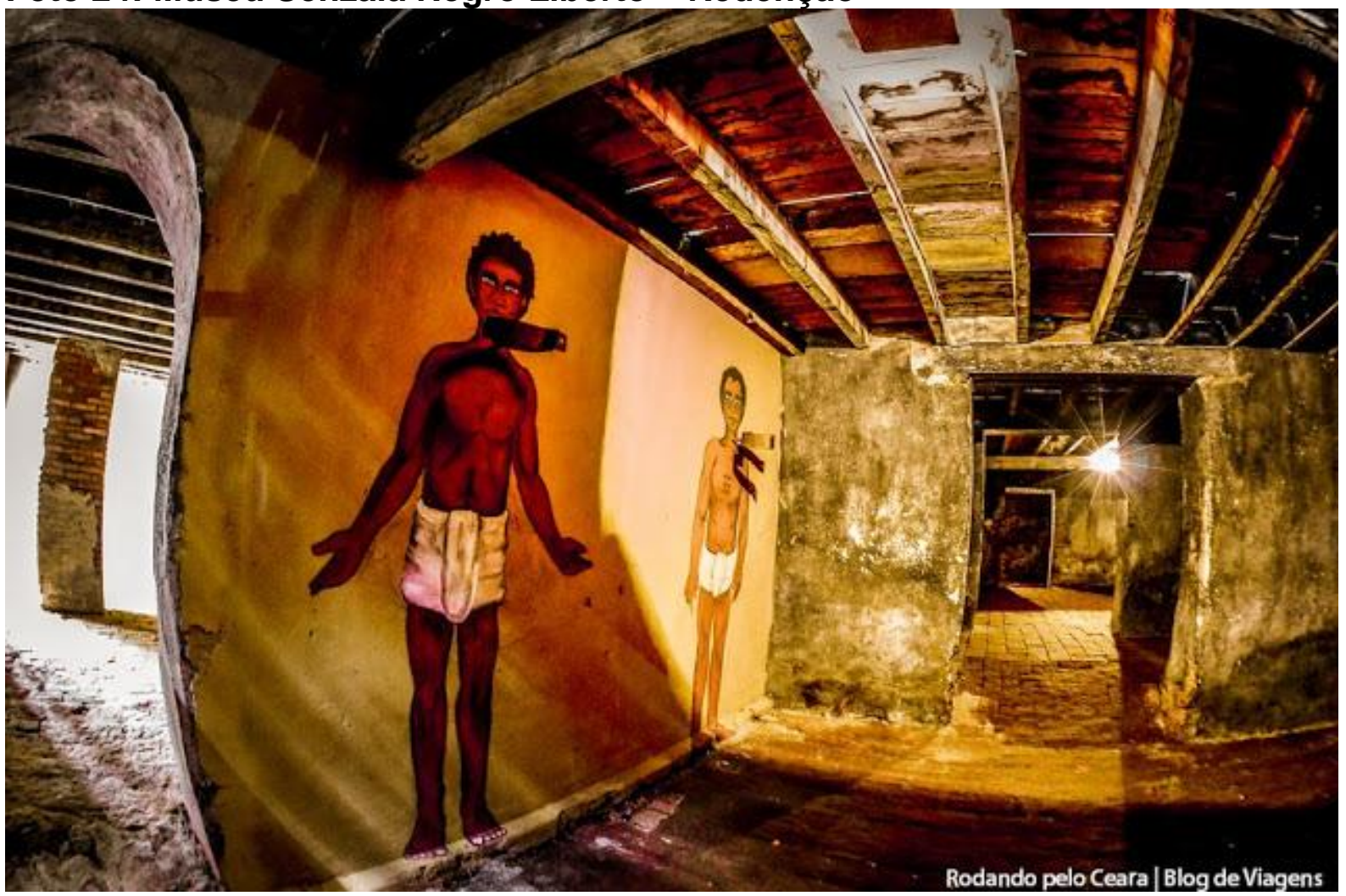

Fonte:

http://www.rodandopeloceara.com.br/2015/11/museu-senzala-negro-libertoredencao.html, 2015.

O município de Trairi apresenta em sua paisagem belas praias com fortes atividades ligadas ao turismo e à pesca. Portanto, atrai diversos usos nesses segmentos, tais como hotelaria, restaurantes, passeios e comércio de artesanatos, bem como a pesca e o cultivo de algas.

No contexto das atividades citadas nessas cidades, por exemplo, Redenção, ressalta-se que investimentos e projetos pensados em conjunto com o ensino profissional técnico, poderiam fortalecer demandas ligadas à educação e à história

${ }^{89}$ Esse museu, que faz parte do centro cultural que também abriga biblioteca pública e ilha digital, tem, em seu acervo, documentos históricos e raros, como livros de compra e venda de escravos, objetos ligados aos escravos - inclusive instrumentos de tortura - peças de antigos engenhos, mobília, objetos sacros, entre outros. 
das localidades. Em cidades com potencialidades similares às de Guaramiranga, a arte e a música poderiam ser horizontalidades a serem exploradas.

Os cursos ofertados na EEEP de Redenção são: Técnico em comércio, computadores, enfermagem e hospedagem. Cursos que, apesar de sua importância, criará uma oferta maior do que as demandas nesses segmentos, podendo ocasionar migração para cidades maiores. Em Trairi, as ofertas são para Técnico em hospedagem, eletrotécnica, edificações e enfermagem. Haja vista que essa cidade tem uma forte potencialidade a ser desenvolvida a partir da pesca, turismo e culinária.

Outra área de propagação que apresenta forte potencial agrícola é a Mesorregião Jaguaribe, que atualmente tem sido usada com maior proporção para o agronegócio da cultura da soja e de frutas tropicais. Porém, com áreas contíguas, cria uma similitude de atividades ${ }^{90}$.

\footnotetext{
${ }^{90}$ As áreas contiguas são áreas de produção agrícola ou urbana, que se modernizam mediante uma informação especializada e levam os comportamentos a uma racionalidade presidida por essa mesma informação que cria uma similitude de atividades (SANTOS, 2005, 257).
} 
Mapa 14: Mesorregião Jaguaribe: usos do território pelas EEEPs

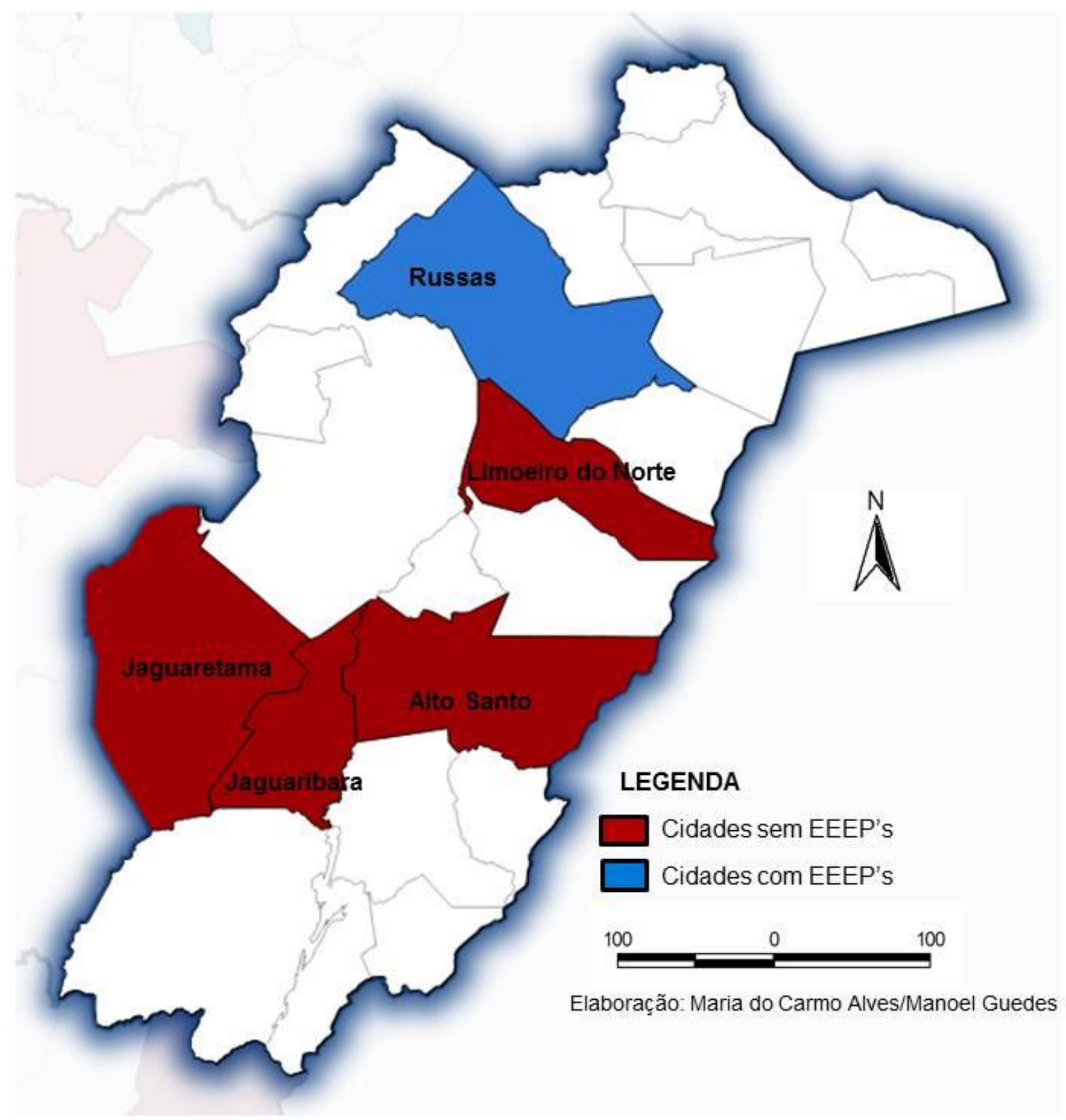


Essa parte do território usado cearense mostrou um forte potencial na agricultura com os perímetros irrigados, mas, similar à microrregião da lbiapaba, é mais aproveitada pelo circuito superior da economia.

Neste contexto, chama-se atenção ao fato de ter localidades que podem se tornar mais autônomas, como Russas ${ }^{91}$ e Limoeiro do Norte ${ }^{92}$, pois possuem, além de um potencial agrícola promissor, dado as boas terras, os investimentos e a concretização do canal da integração, uma população de grande energia e disposição para traçar estratégias que visem um fortalecimento dessas atividades. Isso pôde ser confirmado com visitas feitas em perímetros irrigados, como por exemplo, o Perímetro Irrigado Tabuleiros de Russas ${ }^{93}$, onde se encontrou, em meio a quatro anos de seca, um abandono dos grandes produtores, que teve como consequências o desemprego de mais de mil trabalhadores e a resistência de pequenos produtores de terra que cultivam goiabas, mangas e melancias para sobreviverem. Ambas também destacam-se pela grande produção de mel de abelhas.

Nessa mesma mesorregião, localiza-se Jaguaribara, Alto Santo e Jaguaretama, cidades que tiveram mudanças relevantes nas suas dinâmicas de usos do território, ocasionadas pela construção do Açude Castanhão (Açude Padre Cícero, nome oficial), maior reservatório de água doce do estado, com obras iniciadas em 1995, no governo de Tasso Gereissati, e finalizadas em 2003, no governo de Lúcio Alcântara. Tem capacidade de armazenamento de 6.700.000.000 $\mathrm{m}^{3}$, o que o coloca como o maior açude para múltiplos usos ${ }^{94}$ do Brasil (DNOCS, 2015).

\footnotetext{
91 Russas está situada a $165 \mathrm{~km}$ da capital, conta com o maior projeto irrigado do nordeste juntamente com perímetro irrigado do vale do São Francisco. O projeto tabuleiro de Russas possui 20 mil hectares de área irrigável.

${ }^{92}$ Limoeiro do Norte localiza-se na mesorregião Jaguaribe e microrregião do Baixo Jaguaribe, está a 198 km da capital.

${ }^{93}$ O Perímetro Irrigado Tabuleiros de Russas está localizado nos municípios de Russas, Limoeiro do Norte e Morada Nova, mais precisamente no baixo vale do Jaguaribe, na chamada zona de Transição Norte dos Tabuleiros de Russas.

${ }^{94}$ O Açude Castanhão é utilizado, além do abastecimento de várias cidades do estado, para a agricultura irrigada, piscicultura, pesca (esportiva e de subsistência) e lazer náutico.
} 
Foto 25: Açude Castanhão

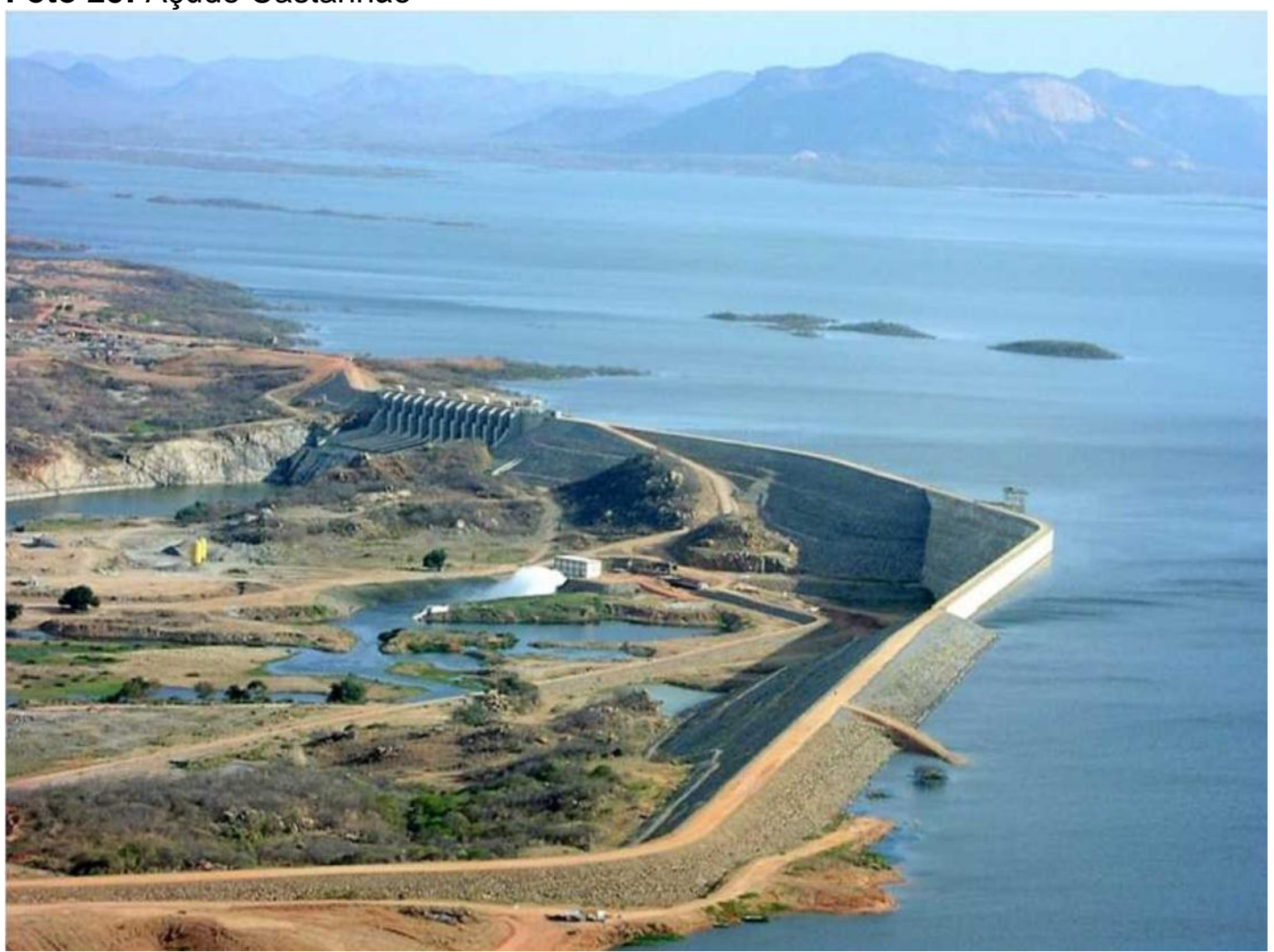

Fonte: http://www.dnocs.gov.br/barragens/castanhao/castanhao.html.

Nessa mesorregião, as cidades que dispõem de EEPs são Aracati, com os cursos de Técnico em informática, enfermagem, comércio, hospedagem; Jaguaribe: Redes de computadores, enfermagem e administração; Pereiro: Moveis, Redes de computadores, Secretaria escolar, administração; Jaguaruana: Agronegócio, redes de computadores, administração e Técnico em meio ambiente; Russas: Informática, massoterapia, comércio e administração, Tabuleiro do Norte Informatica, enfermagem e administração; Morada Nova: Finanças, mecânica, informática, agroindústria.

Chama-se atenção aos cursos ofertados no sentido de que os mesmos poderiam ser pensados para o fortalecimento das demandas locais, que poderiam propiciar um melhor aproveitamento de conhecimentos técnicos para gerir ou mesmo criar usos voltados para melhor atendê-los.

Em conjunto com o ensino regular, poderia propiciar excelentes resultados na promoção de propostas no contexto da agricultura, aquicultura, agropecuária (voltada à criação de pequenos animais), dentre outras. 
Na Mesorregião Sertões Cearenses (mapa), localiza-se Quixadá, distando cerca de $160 \mathrm{~km}$ de Fortaleza, sua geomorfologia é composta por monólitos (formações rochosas isoladas na paisagem), que predominam em grande parte do município, dos quais o mais famoso é a "Pedra da Galinha Choca". No município está também a barragem do Açude Cedro Barra (Foto), datando a sua construção do início da década de 1880 - 1890 (DNOCS, IPECE).

\section{Mapa 15: Mesorregião Sertões Cearenses}

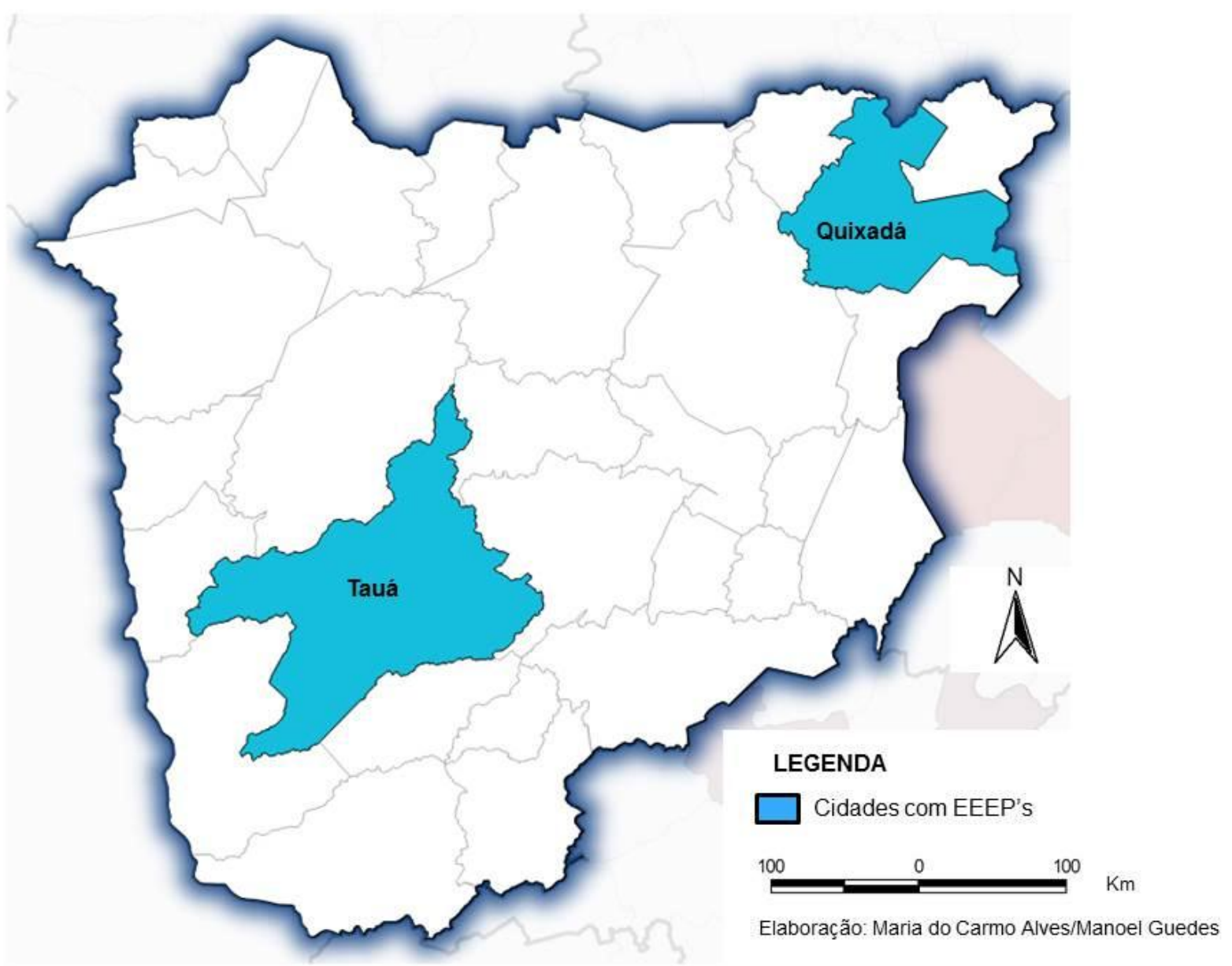

Em Quixadá, existem seis instituições de ensino superior, entre públicas e privadas. Destacam-se o campus da Universidade Federal do Ceará e a Universidade Estadual do Ceará. Por isso, também é considerada cidade universitária, além do destaque no contexto educacional, ela tem um bom potencial para as artes, pois há espaços para o teatro, fotografia, pintura e arquitetura. 
Porém, a EEEP oferta os cursos de Técnico em informática, enfermagem, comercio, agroindústria.

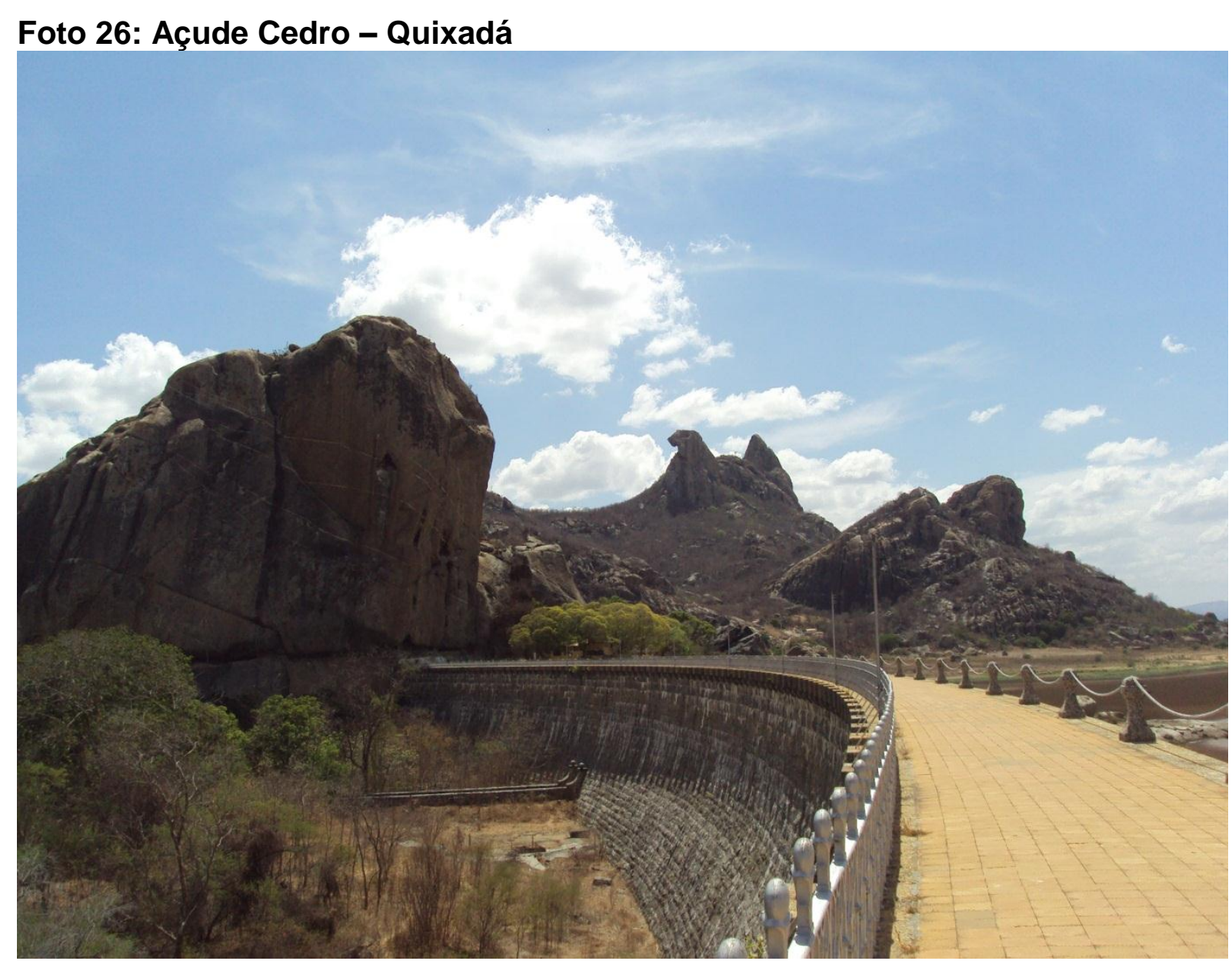

Fonte: MORAES, Jacqueline, 2016.

Tauá conta com um campus do IFCE - Instituto Federal de Educação, Ciência e Tecnologia do Ceará, que oferta os cursos técnicos em Agronegócio e Redes de Computadores, e o curso superior de Tecnologia em Telemática.

A cidade também abriga um campus da UECE - Universidade Estadual do Ceará o CECITEC, que oferece os cursos de Ciências Biológicas, Química e Pedagogia. Conta também com polo da Unopar - Universidade Norte do Paraná (particular) e com um polo da UVA - Universidade Vale do Acaraú. As Universidades de Tauá são bastante procuradas por alunos de várias cidades próximas à Tauá (IPECE, 2015.

Disponível

em:

http://www.ipece.ce.gov.br/perfil_basico_municipal/2015/Taua.pdf). Também conta com uma EEEP, que oferta os cursos: Técnico em informática, enfermagem, Comércio e agroindústria. 
No município de Quixadá, o que se destaca são os setores da administração pública e de serviços (IPECE, 2015). Portanto, algo deveria ser pensado a nível local, como por exemplo, a criação de projetos que pudessem fortalecer iniciativas de convivência no semiárido, a partir de pesquisas desenvolvidas no IFCE, na UECE e nas EEEPs.

$\mathrm{Na}$ Mesorregião Centro-Sul Cearense, localiza-se o município de Icó, distante $375 \mathrm{~km}$ da capital Fortaleza, pela rodovia BR 116. Semelhante à Sobral e Viçosa do Ceará, essa cidade foi tombada pelo IPHAN como patrimônio histórico nacional, em dezembro de 1997, e sua paisagem mostra o aspecto arquitetônico das antigas urbanizações do passado (ALVES, 2016).

Segundo Alves (2017, p.219) "o centro urbano de Icó pode ser considerado o conjunto arquitetônico mais representativo do Ceará, com referência ao número de exemplares ainda íntegros".

A cidade tem 65.500 habitantes, dos quais $53,5 \%$ estão nas zonas rurais e $46,5 \%$ nas zonas urbanas, o que caracteriza Icó como um município ainda basicamente rural. O município no passado se destacava no ramo da agropecuária ${ }^{95}$, porém, atualmente carece de projetos para retomar essa atividade (ARAÚJJO, 2016); pois, partes das terras estão ociosas, dos 4.263,00 ha de área irrigável estão sendo cultivadas, 2.541,00 por pequenos produtores (DNOCS, 2017). Segundo informações do DNOCS, não há técnicos agrícolas no perímetro.

Sobre emprego e renda, Icó conta com vários serviços públicos e privados (IPECE, 2016 http://www.ipece.ce.gov.br/perfil_basico_municipal/2016/lco.pdf), que são usados por pessoas dos distritos icoenses, além dos municípios de Baixio, Orós e Umari, que utilizam os serviços financeiros e comerciais, motivados pela facilidade de meios de transporte diversos e diários à cidade de Icó. Dentre esses serviços, destacam-se o Departamento Nacional de Obras contra as Secas (Dnocs); uma unidade de atendimento da Receita Federal; o Hospital Regional; a Coordenadoria Regional de Desenvolvimento da Educação da Educação (Crede 17), da Secretaria de Educação do Ceará (Seduc); faculdades privadas, como a Vale do Rio Salgado

\footnotetext{
${ }^{95}$ No ramo da agropecuária, o Perímetro Irrigado Icó-Lima Campos foi implantado em 1969, e os serviços de administração, operação e manutenção da infraestrutura de uso comum tiveram início no ano de 1973. É abastecido por água do Açude Público Federal Lima Campos com capacidade de $66.382 .000 \mathrm{~m}^{3}$ e pelo Açude Público Federal Orós, com capacidade de $2.100 .000 .000 \mathrm{~m}^{3}$. Produz atualmente arroz, feijão, milho, banana, coco, graviola, manga e capim de corte (DNOCS, 2016).
} 
(FVS); a Escola Profissional (EEEP); bancos públicos e privados (Brasil, Caixa Econômica Federal e Bradesco) e um comércio bem variado (ARAÚJO, 2016).

Os cursos técnicos ofertados na EEEP do município de Icó são: Técnico em Mecânica, agronegócio, aquicultura e agrimensura. Entende-se que os mesmos poderiam ser modificados no sentido de buscar atender e/ou fortalecer as demandas já citadas.

Na mesma Mesorregião Centro-Sul Cearense, se destaca Iguatu, município que se configura como o principal pólo econômico dessa mesorregião, pois exerce o papel de centro regional de comércio e serviços, recebendo pessoas de vários munícipios circunvizinhos para seus usos. Não é à toa que Iguatu apresentou um PIB de $R \$ 480.185$, sendo $77,85 \%$ oriundos do comércio e serviços (CAVALCANTE; BAIMA, 2011).

\section{Mapa 16: Mesorregião centro-sul cearense: usos do território pelas EEEPs}

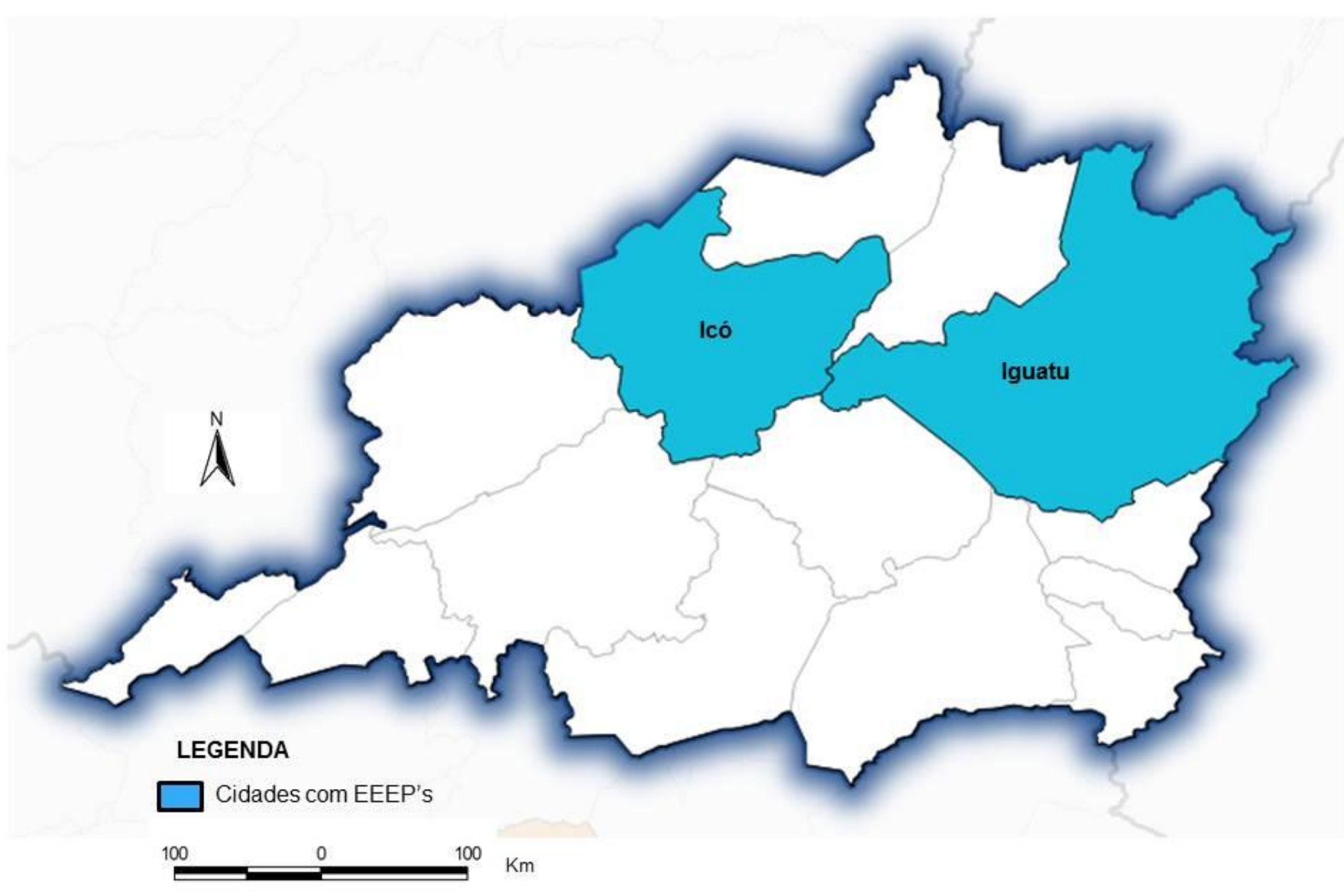

Elaboração cartográfica: Maria do Carmo Alves/Manoel Guedes 
No município, encontram-se equipamentos como Universidades (Universidade Estadual do Ceará - UECE); Universidade Regional do Cariri - URCA), Institutos (Instituto Federal do Ceará- IFCE, Instituto Dom José - IDJ), Faculdades (Faculdade de Ciências e Letras de Iguatu - FECLI, Faculdade de Tecnologia Centec - FATEC, Faculdade São Francisco do Ceará (FASC), Escolas públicas e privadas, Hospitais, Museus, dentre outros; o que lhe concede uma dinâmica espacial de destaque na mesorregião. Outras atividades que se configuram são: a agropecuária, indústria de transformação e administração pública (IPECE, 2014).

Conta com duas EEEPs que ofertam os cursos de técnico em Informática, enfermagem, administração, edificações, eletrotécnica, móveis e finanças. Como já citado, enfatiza-se que os cursos ofertados poderiam ser repensados no sentido de potencializar outros usos, principalmente no setor de serviços.

$\mathrm{Na}$ Mesorregião Sul Cearense, Juazeiro do Norte destaca-se como o mais dinâmico centro religioso do Nordeste. Agregada a essa atividade, o município desenvolveu um importante comércio que atende vários municípios, alguns dos quais, fora do estado do Ceará. É uma cidade que se conturbou com as do entorno, no caso Crato e Barbalha. 


\section{Mapa 17: Mesorregião sul cearense: usos do território pelas EEEPs}

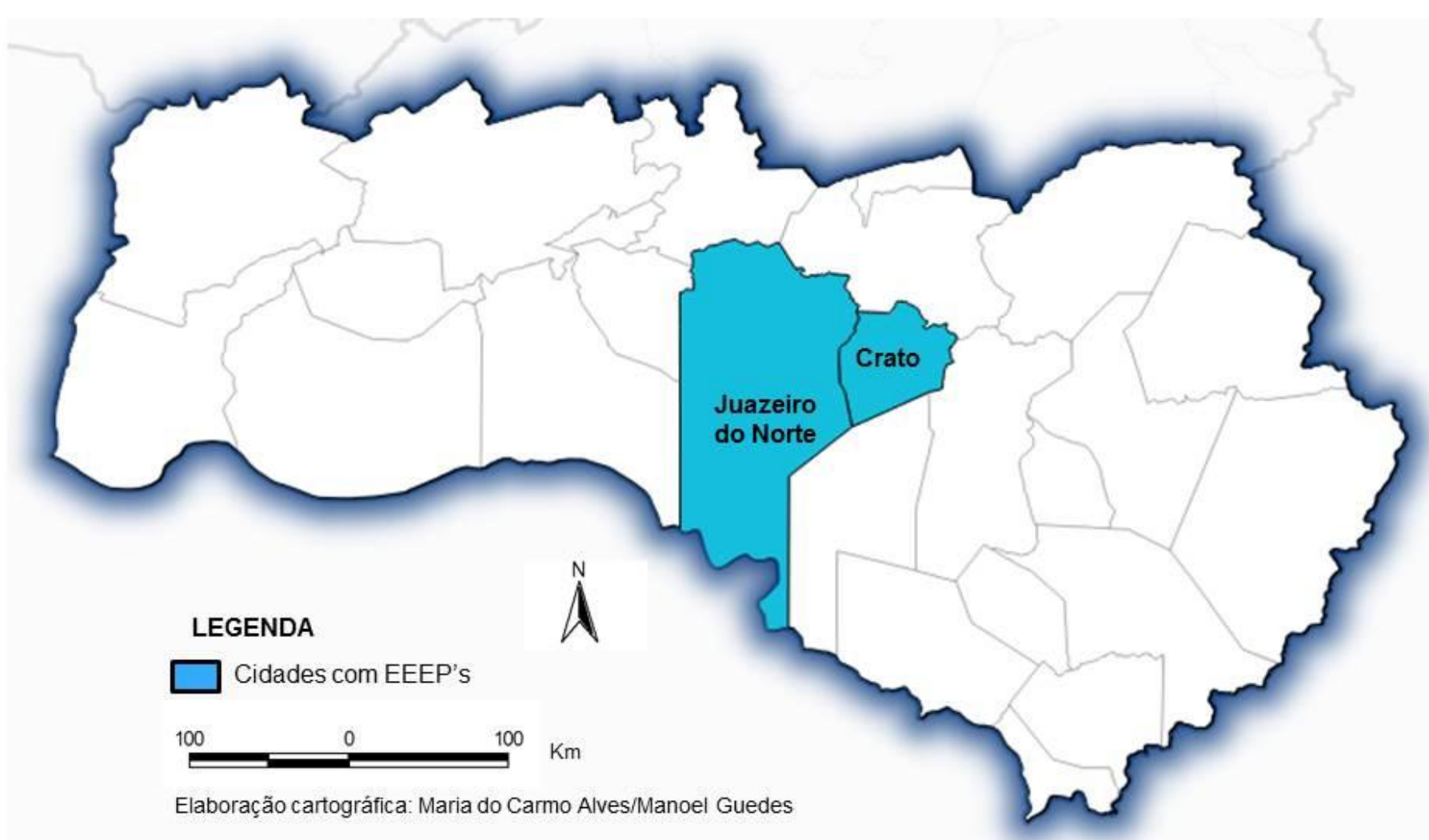

Crato é a sede da Universidade Regional do Cariri (URCA), dividindo, atualmente, com a cidade vizinha de Juazeiro do Norte, a função educacional, contando com várias instituições de ensino superior, inclusive, com uma faculdade de medicina. Crato teve no ano de 2014 um PIB de $R \$ 1.478 .136$, sendo que 716.940 foram gerados no setor de serviços. (IBGE, 2014).

A indústria de transformação também é representativa em Juazeiro do Norte, com $28,45 \%$ dos empregos formais e, na cidade do Crato, com 25,81\% (IBGE, 2014).

Juazeiro do Norte apresentou o maior crescimento nas últimas quatro décadas, com aumento populacional da ordem de 160\%, sendo que na derradeira década registrou um acréscimo de 17,80\%. Crato também apresenta taxas de crescimento demográfico expressivas para o mesmo intervalo considerado, ou seja, de 1970 a 2010 (HOLANDA, BAIMA, 201, p.11). 
No que diz respeito às demandas territoriais, essas estão atreladas à diversificação tanto de bens comerciais quanto de serviços, aliados às modernas formas de consumo (HOLANDA, BAIMA, 2011, p. 6).

Os investimentos direcionados a esses setores já citados, impulsionam os usos do território a conexões verticalizadas, visto que passam a demandar atividades vinculadas ao meio-técnico-cientifico-informacional.

\begin{abstract}
Esse modelo de gestão, de certa forma sustentada pelas gestões municipais, ao aderirem ao modelo de gestão estadual, auto nomeada de moderna, com uma politica fiscal mais austera e constante preparação do território, para atração de novos empreendimentos que se instalam no espaço intraurbano (HOLANDA, BAIMA, 2011, p. 6)
\end{abstract}

No Crato, os cursos ofertados pela EEEP são: Técnico em redes de computadores, regência, enfermagem, informática, automotiva, estética, Técnico em Gestão da Produção Cultural, Técnico em Produção de Áudio e Vídeo.

Juazeiro do Norte possui três EEEPs, onde são ofertados os cursos de Técnico em informática, hospedagem, segurança do trabalho, massoterapia, enfermagem, administração, desenho de construção civil, agrimensura, transações imobiliárias e edificações. Ressalta-se que, nessas cidades, os cursos têm contribuído para efetivar o modelo de gestão adotado, subsidiando a ideologia condizente com a ideia do mercado.

Acredita-se que esses municípios, como um todo, têm fortes potenciais no que diz respeito ao turismo religioso, agregado ao comercio de produtos artesanais locais, com possibilidades de impulsionar pequenas indústrias. Crato, assim como Juazeiro do Norte, possui hotéis, e um comércio forte e dinâmico, que poderia impulsionar outras atividades ligadas à cultura, agricultura e pecuária.

A Região Metropolitana de Fortaleza, considerada nesse trabalho, como uma zona luminosa, ou seja, onde há uma maior incidência técnica, abriga um número considerável de EEEPs. Enfatiza-se que os cursos ofertados tem um maior aproveitamento no sentido das demandas, pois trata-se de um território que apresenta uma maior oferta ligada ao ensino técnico. 


\section{Mapa 18: Região Metropolitana de Fortaleza}

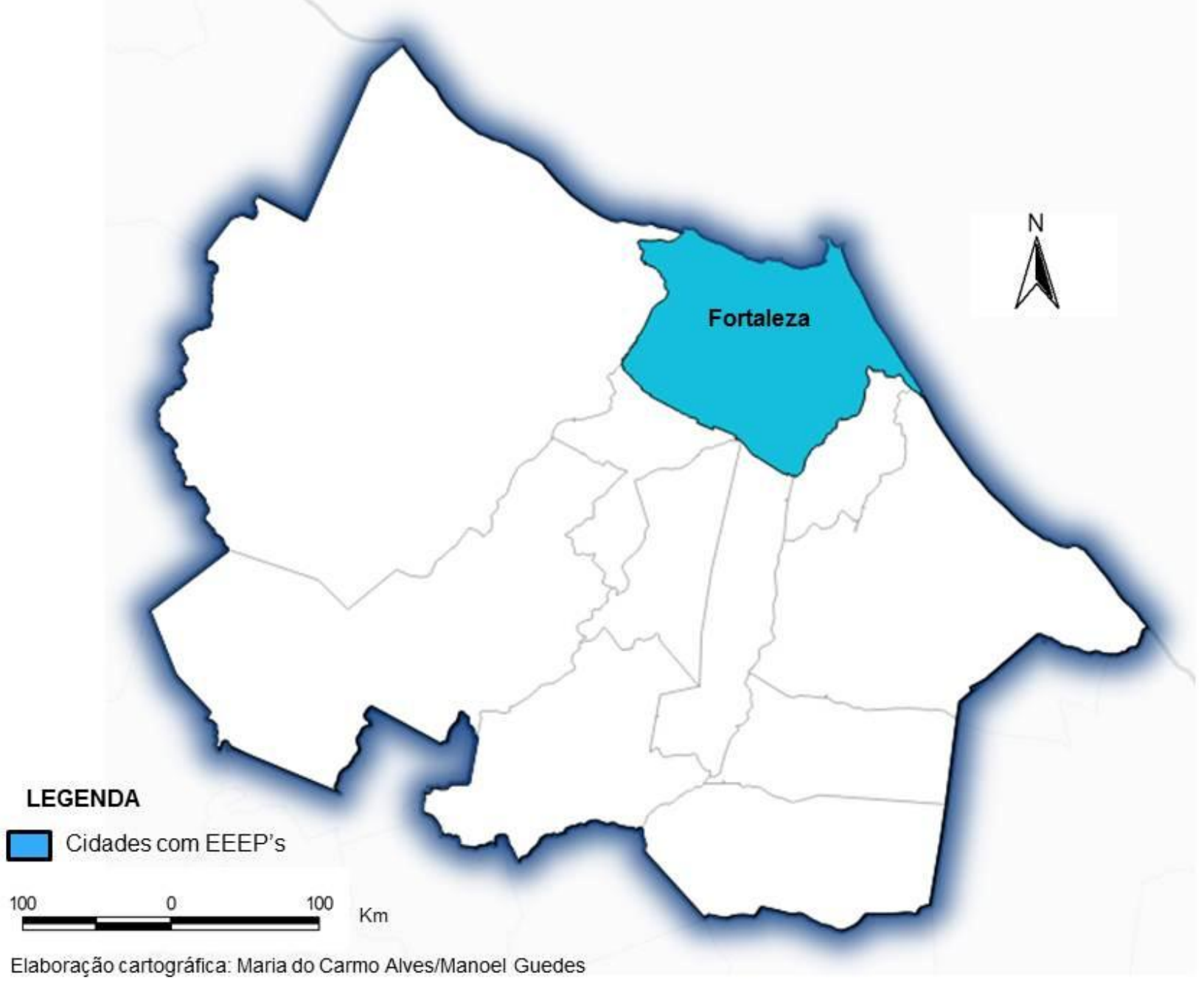

Por se tratar de uma cidade que se constitui no contexto das metrópoles mundiais, dispõe de equipamentos diversos dos grandes centros urbanos, apresenta uma variedade de usos que tem estreitas ligações com o meio-técnico-científicoinformacional.

Fortaleza, como outras metrópoles, agrega os atributos exigidos pelas corporações, ou seja, espaços racionais, "complexos, de manifestações particulares do fenômeno urbano, que favorecem a floração de uma multiplicidade de atividades localmente complementares" (SANTOS, apud SANTOS; SILVEIRA, 2008, p. 434435).

A multiplicidade de funções eficientes que a metrópole desempenha leva à concentração financeira, econômica, cultural, informacional, que se traduz em alterações da função urbana, em modificações brutais da lógica interna da cidade, mas também em uma 
surpreendente operação de estranhamento, que é condição para a superação do hábito. Em que pese as inúmeras diferenças entre processos de metropolização por que passaram as cidades mundiais, existe uma raiz comum entre elas, que é o fato de que, em um determinado momento de sua história, elas extravasam seus limites locais para se tornarem pontos de interesse e de convergência de atividades econômicas, de comando financeiro, de concentração da produção científica e cultural e do desenvolvimento de todas as formas de comunicação, o que lhes confere capacidade crescente de gerar fluxos indispensáveis ao trabalho produtivo (SILVEIRA, 2008, p. 434-435).

Nesse aspecto, as metrópoles se adequam às demandas das grandes corporações e, ao mesmo tempo, reagem a isso. Consequência disso é a exclusão daqueles que não foram considerados para se encaixarem nessa lógica, promovendo-se a desigualdade socioterritorial, tendo a violência como resultado dessa, pois "as metrópoles são também essencialmente, os lugares da pobreza" (SANTOS; SILVEIRA, 2008, p. 435).

Por outro lado, Fortaleza também possui um número expressivo de pessoas que se projetam a reinventar os usos do território, e se utilizam dos muitos potenciais que a cidade oferece para gerar solidariedades horizontais, como as feirinhas, os shows e vendas de produtos diversos, no calçadão da Avenida Beira Mar, as festas de rua, a criação de espaços alternativos de formação e cuidados com as pessoas, dentre outras. Destaca-se que essas são algumas das tantas possibilidades de uso do território que poderiam ser mais bem exploradas no sentido de potencializar usos mais horizontais.

Com relação às EEEPs, tanto as instaladas na capital, como as demais espalhadas pelo estado, se encaixam nesses dois aspectos. Elas são consideradas consequências das atividades econômicas, mas também são respostas a outras questões sociais como a desigualdade e a violência. Foram pensadas para atender ao modelo corporativo, mas permite outras possibilidades de se fazer educação. Os cursos são vinculados ao modelo racional de uso do território, mas responde a isso com a adoção de valores, tais como, o respeito, a crença numa sociedade melhor, e com a formação de alunos que optam pela universidade e outras concepções de mundo.

Em síntese, pode-se dizer que há atualmente um enorme volume de técnicas e informações sobre os territórios e suas possibilidades de usos. Cada vez mais, isso coloca-se disponível por meio de redes de informações, que podem ser 
acessadas por um conjunto maior de pessoas ou instituições, possibilitando maior conhecimento da realidade.

Esse uso social, não hegemônico, poderia mobilizar cada vez mais pessoas para o conhecimento acerca da riqueza socialmente produzida, suficiente para diminuir a miséria e seus males; e assim propiciar uma melhor qualidade de vida para um maior número de pessoas nos lugares.

Destaca-se, sobretudo, investimentos em áreas sociais, abarcando a arte (musica, artesanato, dança, fotografia, pintura), a história (patrimônio histórico, rugosidades, história local, história do Ceará e do Brasil), dentre outras, que poderia - dentro de pouco tempo - gerar respostas favoráveis para a melhoria da qualidade de vida das pessoas.

Infelizmente, concorda-se com Santos quando o mesmo fala que "as motivações de uso dos sistemas técnicos são crescentemente estranhas às lógicas locais e, mesmo, nacionais, e a importância da troca na sobrevivência do grupo também cresce." (SANTOS, 2012, p. 237).

Acredita-se que se invertendo a aplicação de recursos consumidos, em volumes cada vez maiores para outros setores, - que muitas vezes contribui para um desajuste estrutural - e destinando esses recursos para outros setores, que mais se assemelhe às características do povo cearense, poderia surtir um efeito positivo.

Necessário se faz o debate no intuito de buscar essas alternativas para uma coesão social, onde o avanço técnico-cientifico-informacional seja utilizado para prover uma evolução com vistas aos seres humanos.

Nesse aspecto, também o Ensino técnico deverá ser valorizado, pois propiciará novos usos que incidirá positivamente no território usado. Concorda-se com a visão do ex-governador quando esse fala sobre a visão que se tem do ensino técnico.

o ideal é que fizesse o técnico, não ficasse no ensino superior, ficasse no técnico né. Tem uma cultura ainda de pouca valorização, aí é uma cultura da nossa economia, do nosso empresário, até porque não tinha, eu lhe disse a gente era meio profissional de nível técnico para um profissional de nível superior. Então o empresário tem essa cultura de querer ainda o nível superior, mas essa cultura essa coisa vai mudando com o tempo, na medida em que você forma bons profissionais de nível técnico. 
Acredita-se que existam possibilidades de tornar isso efetivo, pois, a história está sempre em processo de construção e mudanças, numa relação dialética constante entre sujeito e objeto, entre pensamento e ação; o que pode ocasionar transformações no espaço geográfico, para que o mesmo possa vir a tornar-se bom para se viver.

Portanto, terá que se insistir numa perspectiva humanista de usos do território, de modo que possa congregar o maior número de pessoas possível, sem exclusão, como um sistema que precisa ser equilibrado, como uma cadeia que não se rompa, pois o mundo pertence a todos que nele nasce.

Se, somos nós, produtos e agentes da história, se a constituímos, então, habita em nós, somente em nós, a possibilidade de modificá-la, de convertê-la num presente transformador para um futuro melhor. 


\section{CONSIDERAÇÔES FINAIS}

Feita a revolução nas escolas, o povo a fará nas ruas.

Florestan Fernandes

\section{O uso do território pela educação técnica profissional cearense se constitui num uso corporativo do território pouco expressando o uso do} espaço banal indispensável ainda para a sociedade cearense, visto que a maior parte dos investimentos são destinados para atender a setores da economia global, gerando conflitos entre 0 ato de produzir e de viver.

A partir das análises do uso do território cearense considera-se que 0 território usado pela educação técnica, constitui em grande parte, um projeto de transmissão de fundamentos alicerçados em demandas provenientes de uma organização espacial baseada numa lógica econômica global, vista quase sempre, como princípio de organização espacial da sociedade.

Ressalta-se que o atendimento as demandas, citado no decreto que normatiza a EPMI, não se sustenta, pois no que se refere as localidades, as mesmas não agregam o quantitativo de alunos formados nos cursos ofertados. Por outro lado, o uso do território responde a isso de outras maneiras, quando a educação profissional integrada ganha força e se torna referência em todo o Estado, pois as referidas escolas se destaquem no IDEB, nas avaliações externas (Sistema Permanente de Avaliação da Educação Básica do Ceará - SPAECE, Sistema de Avaliação da Educação Básica - SAEB, Exame Nacional do Ensino Médio - ENEM), nos índices de aprovação em vestibulares, nos rendimentos e conclusão do ensino médio, se mostrando um meio de conduzir a outras possibilidades de usos do território.

Destaca-se também, que o fato de ofertarem um ensino integral, bem como, disporem de bons equipamentos, bons professores e gestão escolar organizada faz com que a educação publica ganhe força e credibilidade, fazendo cair por terra o discurso da má gestão e aplicação do dinheiro público na educação. 
A saber, que os alunos se encaminham para a universidade, ou mesmo assumem outras atividades que pouco ou não tem relação com os cursos técnicos profissionais que fizeram.

Como sugestão, defende-se que alguns desses cursos poderiam ser ofertados em localidades onde as demandas realmente existem, ou seja, em zonas luminosas, onde as densidades técnicas são mais presentes. Porém ressalta-se que a educação não deve se desvincular do que se propõe, ou seja, uma formação humana compromissada com a sociedade como um todo. Para outras localidades sugere-se alternativas para o uso de técnicas e formação de cursos técnicos que agreguem resultados positivos e eficazes, como alguns exemplos demonstrados no último capitulo.

Acrescenta-se que o debate em torno da educação como forma de sustentar arranjos, para o crescimento econômico no contexto de uma economia global, não torna a educação capaz de edificar outro tipo de economia produtiva, - que vise à propensão de políticas para potencializar outras formas de uso do território, de modo que possa agregar um maior número de pessoas - ao contrário, essa ideologia vista, aceita e aplicada, forma pessoas para se inserir no modelo de sociedade que a mesma educação busca modificar.

Pois a medida que a sociedade tem uma orientação de fundo hegemônica, os ideais de uma educação libertadora, emancipadora, voltada para a cidadania e a equidade, perde espaço para um projeto de educação que comunga com uma visão de mundo dividido e excludente.

Ressalta-se que o modelo de educação básica tal como se apresenta no Brasil, ainda não tem uma definição clara sobre que tipo de ser humano se quer formar. Pois não há um projeto de educação consistente.

Embora tenha havido esforços por meio de trabalhos e pesquisas, bem como movimentos sociais, culturais, políticos, a educação brasileira ainda tem no seu contexto, a oposição entre a ideia de uma educação clássica, humanista e a de uma educação prática, voltada essencialmente à inserção das pessoas no mundo do trabalho.

Também, a educação brasileira e Cearense ainda apresenta sérios problemas no que se refere à qualidade. $\mathrm{O}$ analfabetismo funcional é uma realidade e a "educação para todos" não agrega os requisitos necessários para a promoção do acesso a uma educação de qualidade que agregue realmente a todos. Como parte 
desse processo, o ideal de uma educação unitária, voltada para formar cidadãos tem sua eficácia comprometida.

Além disso, há uma exaltação ao privado em detrimento do público, quando setores da sociedade consideram que a função da educação é garantir, aos seus filhos, status e acesso a uma renda diferencial.

Como consequência disso, as escolas consideradas ideais passaram a ser vistas como empresas especializadas em prestar um serviço à capacitação para um mercado de trabalho excludente e competitivo.

Nesse aspecto, a educação pública fica renegada e desacreditada, pois já não articula as práticas sociais dominantes, hegemonizadas pela ideologia difundida pelo mercado, com seu apelo concorrencial e sua velocidade. O que tem como resultado a subestimação da importância da cidadania e o não reconhecimento da importância dos conhecimentos consolidados, para a compreensão do contexto social como um todo.

A tirania de uma hegemonia do mercado pressupõe o domínio ideológico do pensar alicerçados nos modos de vida baseados no consumo, na indiferença, na desigualdade, na exploração da força do trabalho de uns para suprir a ganância de outros. A educação é muitas vezes usada como ferramenta para manter tal sistema, e por ele ter mais força, acaba predominando. Contudo, ela também anda na contramão e produz resistências e outras formas de pensamento que podem nos libertar.

Dito isso, ressalta-se que necessário se faz repensar a função da educação escolar, sobretudo, quando esta pretende formar cidadãos e trabalhadores. Pois, Educar é também agir no espaço geográfico, é sentir-se parte integrante desse espaço, co-responsável por ele. O mundo nesse sentido, só se tornará abrigo, se abarcar e considerar todos. A luta não é fácil, mas não se pode desanimar.

Atualmente o país enfrenta um retrocesso em vários aspectos, assistiu-se a um golpe de Estado e setores conservadores tem alcançado adeptos em suas empreitadas na supressão de direitos conquistados.

Os meios de comunicação estão cada vez mais sendo utilizados para promover ideologias que acirram discussões sociais desvinculadas da Política Nacional e mundial, o que resulta numa incapacidade de comunicação e partilhamento daquilo que é fundamental para a vida em sociedade. Nesse quesito, reforça-se que a escola ainda é o lugar de resistência e criação de possibilidades 
para reverter e gerar outras formas de ver e viver no mundo, pois, as interações humanas podem coexistir além das ideologias dominantes.

No sistema escolar essas interações tem o poder de alcançar maiores proporções por concentrar agentes de varias classes sociais e, os professores são os principais condutores desse processo e devem ter clareza dos objetivos a serem alcançados. Saber que seu papel é, sobretudo, formar pessoas, e que as mesmas precisam aprender o cuidado recíproco, pois se uma parte do todo se quebra, é desencadeado uma série de rupturas nas demais estruturas que o compõe.

O que se deve é lutar para garantir que essa outra possibilidade de ver o mundo seja efetivamente adotada e consiga enfim, imperar sobre qualquer tipo de educação que escravize o humano ou o faça desumano.

A educação deve considerar que sua função é atender a sociedade como um todo, não privilegiando os interesses dos grupos detentores do poder econômico. Deve ter como fim a formação de uma sociedade mais igual, não deve tomar como ponto de partida o mercado, porque supõe incorporar nesta, um modelo de desenvolvimento social profundamente injusto, que gera miséria e exclusão na maior parte dos casos, salvo raríssimas exceções.

Deve estabelecer como prioritários programas de ação universalizantes, que possibilitem a incorporação de conquistas sociais pelos agentes desfavorecidos, visando à reversão do desequilíbrio social.

Deve propiciar uma tomada de consciência sobre o tipo de sociedade que somos e a que almejamos (FREIRE, 1996), fornecendo subsídios para se pensar a condução de políticas que visem o bem estar do povo em geral, que faça refletir sobre os princípios baseados na democracia, na estabilidade, no respeito, na solidariedade e na igualdade (BRASIL, 1988).

É dever da escola formar o sujeito livre, fornecendo o conhecimento necessário para o entendimento daquilo que deu bases para a formação da humanidade, no intuito de saber como a história se processou e como a partir dos eventos, das ações, chegou-se ao que se tornou a humanidade hoje. Também deve propiciar o acesso à arte, a técnica e ensinar valores de boa convivência social, de consciência da responsabilidade de todos, para com todos.

Acredita-se que há como efetivar essas mudanças, e o Ceará está no caminho quando propõe, e investe no ensino de tempo integral, público. Pois se 
trata de um projeto inovador que apresenta bons resultados de aprendizagem. Além disso, permite aos alunos optarem pelo ensino superior caso queiram.

Porém enfatiza-se que esses esforços empreendidos poderiam resultar em algo maior, no que diz respeito ao currículo técnico, no sentido dos usos dos conhecimentos para a promoção de uma efetiva cidadania.

Também na inserção de saberes que pudesse proporcionar não só a capacidade de aprender a adaptar-se, mas, sobretudo, desse suporte para transformar a realidade, para nela intervir, recriando-a (FREIRE, 1996, p. 69) e suplantando conhecimentos, com vistas a fazer com que a sociedade possa superar suas limitações, buscando melhorar a condição humana, de modo que as injustiças sejam amenizadas e/ou superadas e o ser humano possa humanizar-se, no sentido mais amplo da palavra. 


\section{REFERÊNCIAS}

ABBAGNANO, Nicola. Dicionário de filosofia. Trad. da 1aㅡ Ed brasileira coordenada e revista por Alfredo Bossi; revisão da tradução e tradução de novos textos Ivone Castilho Benedetti. - 5aㅡ Ed. - São Paulo: Martins Fontes, 2007.

ALMEIDA, M. C. Em diversos pontos da rede: divisão territorial das operações de contact center no Brasil. GEOUSP - Espaço e Tempo, São Paulo, v. 18, n. 3, p. 512-530, 2014. Disponível em: http://www.revistas.usp.br/geousp/article/view/83537. Acesso em: 12 de Junho de 2017.

ALMEIDA, Elisa. Refuncionalização da metrópole no período técnico-científicoinformacional e os novos serviços In: Santos, Milton; SILVEIRA, Maria Laura. O

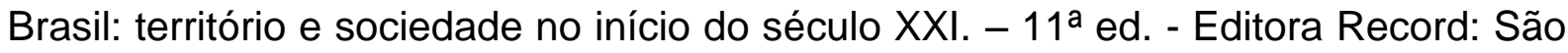
Paulo, 2008.

ALMEIDA, Humberto Marinho. Políticas Públicas, Governo e Desenvolvimento Práticas espaciais, gestão seletiva e o desenvolvimento territorial no Ceará. XV Encontro de ciências sociais do norte e nordeste pré-alas Brasil 04 a 07 de setembro de 2012, UFPI, Teresina-PI. Disponível em: https://mafiadoc.com/desenvolvimento-economico-do-ceara-sinteseeventos_59d8cb581723dd3b32a62be1.html Acesso em: 27 de março de 2016.

ALVES, Joaquim. O ensino primário na primeira metade do século $X X$. In GIRÃO, Raimundo; MARTINS FILHO, Antônio. O Ceará - 3 ed. Fortaleza: Editora Instituto do do Ceará, 1966.

ALVES, Maria do Carmo. Usos do território e rugosidades: Fundamentos Socioespaciais do Patrimônio Histórico do Estado do Ceará. Tese apresentada ao Programa de Pós-Graduação em Geografia Humana da Faculdade de Filosofia, Letras Ciências Humanas da Universidade de São Paulo. Sob a orientação do professor doutor Francisco Capuano Scarlato.

BAIMA, Zenilde. Aspectos Históricos da Industrialização do Ceará. IN: SOUZA, Simone (Coord). História do Ceará. Fortaleza: Demócrito Rocha, 1989.

AMORIM, Cassiano Caon. O uso do território brasileiro e as instituições de ensino superior. Tese apresentada ao Programa de Pós-Graduação em Geografia Humana da Faculdade de Filosofia, Letras Ciências Humanas da Universidade de São Paulo. Sob a orientação da professora doutora Maria Adélia Aparecida de Souza.

ANDRADE, Manuel Correia de. Élisée Reclus. Geografia. São Paulo: Ática, 1985. A questão do território no Brasil. São Paulo: Hucitec, 2004. 
ARARIPE, Tristão de Alencar. História da província do Ceará: dos tempos primitivos até 1850. Fortaleza: Edições Demócrito Rocha, 2002.

ARAÚJO, Tânia Bacelar. Herança de diferenciação e futuro de fragmentação. Revista Estudos Avançados, Dossiê Nordeste, São Paulo, v. 11, n. 29, abr. 1997. Disponível em: http://www.revistas.usp.br/eav/article/view/8971/10523. Acesso em: 13 de Setembro de 2016.

\begin{tabular}{cccccc} 
& Nordeste: & desenvolvimento recente & e & perspectivas & (2011). \\
\hline Biblioteca & Digital & - & BNDS. & Disponível & em:
\end{tabular} http://www.afbnb.com.br/arquivos/File/apoio2\%2047\%20rcr.pdf. Acesso 16 de março de 2017.

ARAÚJO, Feitosa Enos. Entre o distante e o presente: algumas considerações urbanas sobre a cidade de Icó- Ceará. revista de geografia (Recife) Revista de Geografia (Recife) V. 33, No. 1, 2016. Disponível em: http://www.revista.ufpe.br/revistageografia. Acesso em: 24 de Julho de 2017.

ARENDT, H. Entre o passado e o futuro. $3^{\text {a }}$ ed. São Paulo: Perspectiva, 1992.

AMORIM, Cassiano. O uso do território brasileiro e as instituições de ensino superior. Tese apresentada ao Programa de Pós-Graduação em Geografia Humana da Faculdade de Filosofia, Letras Ciências Humanas da Universidade de São Paulo. Sob orientação da professora doutora Maria Adelia Aparecida de Souza, São Paulo, 2010.

BAIMA, Zenilde. Aspectos históricos da industrialização do Ceará. In SOUZA, Simone de. História do Ceará. Fortaleza: Universidade do Ceará/Fundação Demócrito Rocha / Stylus Comunicações, 1989.

BRASIL. Coleções de Leis do Império do Brasil - 1827. Disponível em: http://www2.camara.leg.br/legin/fed/lei_sn/1824-1899/lei-38398-15-outubro-1827566692-publicacaooriginal-90222-pl.html. Acesso 24 de Agosto de 2016.

BRASIL, Constituição da República dos Estados Unidos do Brasil de 1934. http://www2.camara.leg.br/legin/fed/consti/1930-1939/constituicao-1934-16-julho1934-365196-publicacaooriginal-1-pl.htmlconstituições de 1934.

BRASIL. Tribunal de Contas da União. Relatório de auditoria coordenada no Ensino Médio. Disponível em: http://portal2.tcu.gov.br/portal/pls/portal/docs/1/2627713.PDF. Acesso em: 16 de Junho de 2015.

BRASIL. Educação brasileira: indicadores e desafios: documentos de consulta / Organizado pelo Fórum Nacional de Educação. - Brasília: Ministério da Educação, Secretaria Executiva, Secretaria Executiva Adjunta, 2013. 95p.

BRASIL. Constituição dos Estados Unidos do Brasil (De 10 de novembro de 1937). 
http://www.planalto.gov.br/ccivil_03/constituicao/constituicao37.htm. Acesso em: 10 de março de 2015.

BRASIL. Constituição Federal. A Lei n o 11.741, de 16 de julho de 2008. (Altera dispositivos da Lei n o 9.394, de 20 de dezembro de 1996 no que tange a Educação Profissional e Tecnológica) altera o Capítulo III e introduz as Seção IV-A e os artigos 36-A, B, C e D que tratam especificamente da educação profissional técnica de nível médio. Disponível em: http://www.planalto.gov.br/ccivil_03/_Ato20072010/2008/Lei/L11741.htm. Acesso em: 22 de Junho de 2015.

BRASIL. DECRETO № 7.566, DE 23 DE SETEMBRO DE 1909. Cria nas capitanias dos Estados da Escolas de Aprendizes Artífices, para o ensino profissional primário e gratuito.

BRASIL. Constituição Federal. DECRETO № 2.208, DE 17 DE ABRIL DE 1997. Disponível em: http://www.planalto.gov.br/ccivil_03/decreto/D2208.htm

BRASIL. DECRETO № 5.154 DE 23 DE JULHO DE 2004 . http://www.planalto.gov.br/ccivil_03/_ato2004-2006/2004/decreto/d5154.htm

BRASIL. DECRETO № 2.208 DE 17 DE ABRIL DE 1997. Disponível em: http://portal.mec.gov.br/seesp/arquivos/pdf/dec2208.pdf.

BRAUDEL, Fernand. Civilização material, economia e capitalismo, séculos XV-XVIII: I. As estruturas do cotidiano. II. Os jogos da troca. III. O tempo do mundo. São Paulo: Martins Fontes, 1995. 3v.

BRÍGIDO, João. Ceará: homens e fatos. Fortaleza: Edições Demócrito Rocha, 2001.

BRUINI, Eliane. Educação no Brasil. Disponível em: http://www.brasilescola.com/educacao/educacao-no-brasil.htm. Acesso em: 23 de Janeiro de 2015.

BRUM, Argemiro J. O Brasil no contexto mundial. 3. ed. ljuí: Ed. Unijuí, 2006. (Coleção trabalhos acadê- mico-científicos. Série textos didáticos).

CARVALHO, Otamar de. A economia política do Nordeste: secas, irrigação e desenvolvimento. Rio de Janeiro: Campos, 1988.

CASTELLS, Manuel. A sociedade em rede. São Paulo: Paz e Terra, 1999;

O Nosso Mundo, a Nossa Vida; Paraísos Comunais; Identidades Territorias: Comunidades Locais In: CASTELS, M. O beijo da Identidade. Lisboa: Fundação Calouste Gulbenkian, 2003.

CASTRO, Lara de. A seca de 1877 e a formação da multidão (2008). http://www.ce.anpuh.org/download/anais_2008_pdf/Lara\%20de\%20Castro.pdf 
CASTELO, Plácido Aderaldo. História do Ensino no Ceará. Fortaleza: Departamento de Imprensa Oficial, 1970. Coleção Instituto do Ceará. Monografia 22.

CASTILHO, Ricardo. Três dimensões da Solidariedade em Geografia. Revista Experimental, São Paulo, 1997, ano II, n. 3.

CEARÁ. Documentos. Revista do arquivo público do Ceará: história e educação n 2. Fortaleza: Arquivo público do Estado do Ceará, 2006.

CEARÁ. Instituto Federal de Educação, Ciência e Tecnologia do Ceará/IFCE. Histórico. Disponível em: http://ifce.edu.br/acesso-a-informacao/lnstitucional/historico. Acesso em: 21/09/2016.

CEPAL. Educación y conocimiento: eje de la transformación productiva con equidade. Disponível em: http://www.cepal.org/es/publicaciones/2130-educacion-yconocimiento-eje-de-la-transformacion-productiva-con-equidad. Acesso em: 23 de Julho de 2015.

CHAVES, Maria Lucenir Jerônimo, SANTOS, Camila Dutra dos Santos. Agronegócio da fruticultura e da soja: a territorialização de empresas agrícolas nos cerrados e vales úmidos do nordeste brasileiro. Revista GeoUECE, v.2, n.3, Julho/Dezembro 2013. ISSN: 2317-028X.

CHAUNU, Pierre. Conquista e exploração dos Novos mundos (século XVI). Tradução de Jordino Assis dos Santos Marques e Maurílio José de Oliveira Camello. São Paulo: Editora da universidade de São Paulo, 1984.

CORRÊA, Roberto Lobato. Trajetórias geográficas. Rio de Janeiro. Bertrand Brasil, 1997.

. Organização do Espaço: dimensões, processo, forma e significados. GEOGRAFIA, Rio Claro, v. 36, Número Especial, p. 7-16, jan. 2011. Disponível em: https://gen2011urc.files.wordpress.com/2012/03/organizac3a7c3a3odo-espac3a7o-dimensc3b5es-processo-forma-e-significados-e28093-roberto-lobatocorrc3aaa.pdf Acesso em: 14 de março de 2015.

CUNHA, Luiz Antonio. $O$ ensino de ofícios artesanais e manufatureiros no Brasil escravocrata. São Paulo: Editora UNESP, Brasília, DF: Flacso, 2000.

O ensino de ofícios nos primórdios da industrialização. São Paulo: Editora UNESP, Brasília, DF: Flacso, 2000.

DURKHEIM, Emile. Da divisão do trabalho social. Tradução de Eduardo Brandão. - 2ª Edição. - São Paulo: Martins Fontes, 1999.

FAZENDA, Ivani Catarina Arantes. Educação no Brasil Anos 60: Pacto do Silêncio. São Paulo; Edições Loyola, 1985.

FERRETTI. Celso João. O pensamento educacional em Marx e Gramsci e a concepção de politecnia. Trab. Educ. Saúde, Rio de Janeiro, v. 7,suplemento, p. 105-128, 2009 Disponível em: http://www.scielo.br/pdf/tes/v7s1/06.pdf 
FERREIRA. Lavínia Maria de M. Evolução e perfil da oferta de educação profissional: Brasil, grandes regiões e unidades da federação In: OLIVEIRA, Marina Pereira Pires de [et al]. Rede de pesquisa: formação e mercado de trabalho : coletânea de artigos : volume III, educação profissional e tecnológica - Brasília : IPEA : ABDI, 2014. v. 3 (214 p.): il.

FERNANDES, Florestan. O dilema educacional brasileiro In: PEREIRA. Luiz; FORACCHI, Marialice M. Educação e sociedade. - 6 ed. 1 reimp. - São Paulo: Companhia Editora Nacional, 1971.

FIGUEIREDO, Ireni M. Zago. Os projetos financiados pelo Banco Mundial para - Ensino Fundamental no BRASIL. Disponível em: http://www.scielo.br/pdf/es/v30n109/v30n109a10.pdf. Acesso em: 2 de Julho de 2015.

FILLOUX, Jean-Claude. Émile Durkheim. Disponível em: http://www.dominiopublico.gov.br/download/texto/me4657.pdf

FORUM NACIONAL DA EDUCAÇÃO (FNE). Educação brasileira: indicadores e desafios documento de consulta. Disponível em: http://conae2014.mec.gov.br/images/pdf/educacao_brasileira_indicadores_e_desafio s.pdf. Acesso em: 4 de Julho de 2015.

FOUCAULT, Michel. A Ordem do Discurso. (L'Ordre du discours, Leçon inaugurale ao Collège de France prononcée le 2 décembre 1970, Éditions Gallimard, Paris, 1971.). Trad. Edmundo Cordeiro e António Bento. Disponível em: http://www2.eca.usp.br/Ciencias.Linguagem/Foucault_ordemdodiscurso.pdf. Acesso em 15 de Janeiro de 2017.

FRANCHINI NETO, HÉLIO. A Política Externa Independente em ação: a Conferência de Punta del Este de 1962. Rev. Bras. Polít. Int. 48 (2): 129-151 [2005]. Disponivel em: http://www.scielo.br/pdf/rbpi/v48n2/a07v48n2.pdf. Acesso em: 20 de janeiro de 2017.

FREIRE. Paulo. Pedagogia da autonomia: Saberes necessários à prática educativa. São Paulo: Paz e Terra, 1996.

FRIEDMANN, Georges. 7 estudos sobre o homem e a técnica. Tradução de Antônio Eduardo Vieira de Almeida e Eduardo de Oliveira e Oliveira. São Paulo: Difusão Européia do Livro, 1968.

FRIGOTTO, Gaudêncio. A relação da educação profissional e tecnológica com a universalização da educação básica. Disponível em: http://www.scielo.br/pdf/es/v28n100/a2328100.pdf. Acesso em: 10 de Julho de 2014.

GENTILI, Pablo Gentili. La OCDE imbeciliza el concepto de conocimiento. Entrevista Disponível em: http://eldiariodelaeducacion.com/2016/10/03/pablo-gentili-la-ocdeimbeciliza-concepto-conocimiento/. Acesso em: 26 de Março de 2017. 
GIRÃO, Raimundo. Pequena História do Ceará. 2 ed. Fortaleza: Editora Instituto do Ceará, 1962.

Fontenele, 1953.

Pequena História do Ceará. Fortaleza: Editora A. Batista História do Ceará. Editora Instituto do Ceará, 1947.

Evolução Histórica Cearense. Fortaleza: BNT. ETENE, 1985.

História do Ceara Girão:

http://www.raimundogirao.com.br/obra/obras-de-raimundo-girao-empdf/apresentacao-obras-de-raimundo-girao-em-pdf.

GIRÃO, Raimundo; MARTINS FILHO, Antonio. O Ceará - 3aㅗ ed. Ceará, Editora do Instituto do Ceará, 1966.

GIRÃO, Valdelice Carneiro. As charqueadas. Revista do Instituto do Ceará. Disponível em: www.institutodoceara.org.br. Acesso em 25 de maio de 2017.

GRAMSCI, Antonio. Os Intelectuais e a Organização da Cultura. Trad. Carlos Nelson Coutinho. - 4를 ed. Rio de Janeiro: Editora Civilização Brasileira S.A., 1984.

HARVEY, David. Condição Pós-Moderna: uma pesquisa sobre as origens da mudança cultural . 6 ed. São Paulo: Loyola, 1996.

HELD, D.; MCGREW, A. 2001. Prós e contras da globalização. Rio de Janeiro: Jorge Zahar Editor.

HERZ, M. 1999. A internacionalização da política: a perspectiva cosmopolita em face do debate sobre a democratização da ONU. Contexto internacional. Rio de Janeiro: IRI-PUC, vol. 21, n. 2, p. 259-289

HENKES, Silvana L. A política, o direito e o desenvolvimento: um estudo sobre a transposição do rio São Francisco. Disponível em: http://www.scielo.br/scielo.php?script=sci_arttext\&pid=S1808-24322014000200497. Acesso: 16 de outubro de 2016.

HÖFLING, ELOISA DE MATTOS. Estado e políticas (públicas) sociais. Cadernos Cedes, ano XXI, no 55, novembro/2001. Disponivel em: http://scielo.br/pdf/ccedes/v21n55/5539.

HOLANDA, Virginia Célia Cavalcante de; BAIMA, Zenilde. Cidades médias do Ceará, estado do nordeste do Brasil, e suas dinâmicas contemporâneas. Revista Geográfica de América Central, Número Especial EGAL, Año 2011, ISSN2115-2563. http://www.revistas.una.ac.cr/index.php/geografica/article/view/2279. Acesso em: 23 de julho de 2017. 
IBGE. Instituto Brasileiro de Geografia e Estatística. Síntese dos indicadores sociais: uma análise das condições de vida da população brasileira, Rio de Janeiro $2010 . \quad$ Disponível em: http://www.emdialogo.uff.br/sites/default/files/sitese_de_indicadores_sociais_ibge.pdf Acesso em: 4 de Julho de 2015.

JUCÁ NETO, Clovis Ramiro. Os primórdios da organização do espaço territorial e da vila cearense - algumas notas. Departamento e Aqrquitetura e Urbanismo. Universidade Federal do Ceará. Anais do Museu Paulista. São Paulo. N. Sér. V.20 n.1. p. 133-163. Jan. - jun. 2012.

KOSIK. Karel. Dialética do concreto. Traduzido por Célia Neves e Alderico Toríbio. $2^{\mathrm{a}}$ ed. - Rio de Janeiro: Paz e Terra, 1976.

KUENZER, Acacia Zeneida. Da dualidade assumida à dualidade negada: o discurso da flexibilização justifica a inclusão excludente. Educ. Soc. vol.28 no.100 Campinas Oct. 2007. Disponível em: http://www.scielo.br/scielo.php?script=sci_arttext\&pid=S0101-73302007000300024 Acesso e: 22 de Maio de 2016.

LEMOS, Amalia Inés Geraiges. La globalización y su impacto en las áreas urbanas de América Latina. Anales de Geografia, 2004 n. 24 107-121. Disponível em: http://revistas.ucm.es/index.php/AGUC/article/view/AGUC0404110107A/31042. Acesso em: 2 de Setembro de 2015.

A metropolização nos países do terceiro mundo. Revista do departamento da Geografia, n. 13, 1999. Disponível em: http://www.revistas.usp.br/rdg/article/view/53806/57769. Acesso em: 3 de Julho de 2015.

Metropolização e modernidade. As metrópoles da América Latina In: SCARLATO, Francisco C. (org.); SANTOS, Milton; SOUZA, Maria Adélia Aparecida de; ARROYO, Mônica. Globalização e Espaço Latino-americano. 3aㅡ ed. SAO PAULO: HUCITEC-ANPUR, 1997.

LOMBARDI, José Claudinei. Modo de produção, transformações do trabalho e educação em Marx e Engels In: LOMBARDI, José Claudinei; LUCENA, Carlos; PREVITALI, Fabiane Santana [orgs.]. Mundialização do trabalho transição histórica e reformismo educacional. Campinas- SP: Librum Editora, 2014.

LIMA, Luiz Cruz. Reestruturação socioespacial: do espaço banal ao espaço da racionalidade técnica. São Paulo: Annablume, 2006.

LIMA, Luiz Cruz; SANTOS, Elisete de O. Reestruturação socioespacial do território cearense: serviços modernos em evidência nos subespaços dinâmicos (2012). Disponível: http://www.agroambiente.ufrr.br/index.php/actageo/article/viewFile/667/909. Acesso em: 3 de Março de 2015. 
LIMA, Luiz Cruz; VASCONCELOS, Tereza Loiola; FREITAS, Bernadete Maria Coêlho. Os novos espaços seletivos no campo. Fortaleza: EdUECE, 2011.

LIMA, Luiz Cruz; QUINTILIANO, Aridenio Bezerra; FREITAS, Bernadete Maria Coelho; SANTOS, Elizete de Oliveira; SILVA, Francisco Antônio Carneiro; VASCONCELOS, Tereza Sandra Loiola. Reestruturação socioespacial do Ceará. In: ENCONTRO NACIONAL DE GEÓGRAFOS, 15, 2008, São Paulo. Anais do XV Encontro Nacional de Geógrafos: O Espaço Não Pára por uma AGB em Movimento. São Paulo: USP, 2008. 1 CD-ROM.

MARIANO, Karina Pasquariello. Globalização, integração e o Estado. Lua Nova, São Paulo, 71: 123-168, 2007.

MARX, Karl. O Capital, Livro I, Cap. IV (Inédito) - 1르 Ed. São Paulo: Livraria editora ciências humanas, 1978.

MANSO, Carlos [et al]. A quem se destina o plano "brasil sem miséria?: perfil dos extremamente pobres no país. Laboratório de Estudos da Pobreza (LEP) Universidade Federal do Ceará - UFC. Disponível em: http://www.caen.ufc.br/attachments/article/114/rp10.pdf . Acesso: 12 de Julho de 2014.

MENEZES. Djacir A Educação no Ceará. In GIRÃO, Raimundo; MARTINS FILHO, Antonio. O Ceará - 3ª ed. Ceará, Editora do Instituto do Ceará, 1966.

MÉSZÁROS, István. O poder da ideologia. Trad. Paulo Cézar Castanheira. - São Paulo: Boitempo Editorial, 2004.

A educação para além do capital. Disponível em: http://revista-theomai.unq.edu.ar/NUMERO15/ArtMeszaros_15.pdf. Acesso em: 12 de Janeiro de 2015.

MORAES, Carmen Sylvía V. A reforma do ensino médio e a educação profissional. Trabalho e Educação, Belo Horizonte, n", 3, jan.ljul.1998.

NEVES, Frederico de Castro. A miséria na literatura: José do Patrocínio e a seca de 1878 no Ceará. Disponível em: http://www.scielo.br/scielo.php?script=sci_arttext\&pid=S1413-77042007000100005. Acesso em: 4 de Março de 2015.

A seca na história do Ceará. In SOUZA, Simone de et al. Uma nova história do Ceará. Fortaleza: Edições Demócrito Rocha, 2000.

OFFE, Claus. Problemas estruturais do Estado capitalista. Rio de Janeiro: Tempo Brasileiro, 1984.

OLIVEIRA, Francisco de. Elegia para uma re(li)gião: SUDENE, Nordeste. Planejamento e conflito de classes. $3^{\underline{a}}$ ed. Rio de Janeiro: Paz e Terra, 1981. 
OLIVEIRA, Marina Pereira Pires de [et al]. Rede de pesquisa: formação e mercado de trabalho : coletânea de artigos : volume III, educação profissional e tecnológica - Brasília : IPEA : ABDI, 2014. v. 3 (214 p.): il.

OLIVEIRA, Ramon. O legado da CEPAL à educação nos anos 90. Disponível em: http://www.rieoei.org/deloslectores/Oliveira.PDF. Acesso em: 4 de Abril de 2015.

ORTEGA Y GASSET. José. Meditação da técnica. Rio de Janeiro: Livro IberoAmericano, 1963.

PARO, Vitor Henrique. Administração escolar: introdução crítica. 11. Ed. São Paulo: Cortez, 2002.

(org). A teoria do valor em Marx. - 2. ed. - São Paulo: Cortez,

2013.

PEREIRA. Luiz; FORACCHI, Marialice M. Educação e sociedade. -6 ed. 1 reimp.

- São Paulo: Companhia Editora Nacional, 1971.

PINHEIRO, Francisco José. Notas sobre a formação social do Ceará (1680-1820). Fortaleza, Fundação Ana Lima, 2008.

POMPERMAYER, Fabiano M.; CAMPOS NETO, Carlos A. da Silva. Ressurgimento da indústria naval no Brasil: (2000-2013). Brasília: Ipea, 2014. 480 p.: il., gráfs. color. Disponível em: http://www.ipea.gov.br/agencia/images/stories/PDFs/livros/livros/livro_ressurg_da_in d_naval.pdf. Acesso em: 4 de Março de 2015.

PONTES, Davi Oliveira; ARRAES, Ronaldo; MARIANO, Francisca Zilania Mariano; PENA, Cristiano Pena (2002). Crescimento econômico e desigualdade de renda no Ceará. Disponível em: http://www.ipece.ce.gov.br/economia-do-ceara-emdebate/v-

encontro/artigos/CRESCIMENTO\%20ECONOMICO\%20E\%20DESIGUALDADE\%20 DE\%20RENDA\%20NO\%20CEARA.pdf. Acesso em: 4 de Março de 2015.

PONTES. Lana M. Veloso de. Formação do território e evolução políticaadministrativa do Ceará: A questão dos limites municipais. Publicado por Instituto de Pesquisa Estratégia Econômica do Ceará - IPECE, 2009.

PRADO JÚNIOR, Caio. A política brasileira. Revista Brasiliense, n. 8, São Paulo, nov./dez. 1956.

São Paulo: Brasiliense, 1972.

Formação do Brasil Contemporâneo: colônia. 12. ed. . Evolução Política do Brasil Colônia e Império. 18 ed. São Paulo: Brasiliense, 1989.

QUINTILIANO, Aridenio B. Reestruturação socioespacial do Ceará: Estado, Política e Sociedade. Dissertação apresentada ao Mestrado Acadêmico em 
Geografia, do Centro de Ciências e Tecnologia da Universidade Estadual do Ceará para obtenção do título de Mestre. Área de concentração: Análise Geoambiental Integrada e Ordenação do Território nas Regiões Semi-áridas e Litorâneas. Linha de Pesquisa: Sociedade, Espaço e Cultura sob a Orientação do Prof. Dr. Luiz Cruz Lima, Ceará, 2008.

RECLUS, Elisée. A evolução, a revolução e o ideal anarquista. Tradução de Plínio Augusto Coelho. - São Paulo: Imaginário, 2002.

RIBEIRO, Ana C. Torres. Pequena reflexão sobre categoria da teoria crítica do espaço: território usado, território praticado In: SOUZA, Maria Adélia Aparecida de [et al.]. Território Brasileiro: usos e abusos. Campinas: Edições TERRITORIAL, 2003.

RIBEIRO, Darcy. Educação para o desenvolvimento in NETO, Maria Inácia D'ávila (org.). Desenvolvimento social: desafios e estratégias. Vol. II. Rio de Janeiro: Cátedra da UNESCO de Desenvolvimento Durável -UFRJ/EICOS, 1995.

SARTRE, Jean Paul. O Existencialismo é um Humanismo. In: Os Pensadores. São Paulo: Abril Cultural, 1978.

1996.

Questão de método. São Paulo: Difusão Européia do Livro,

Crítica da razão dialética. Tradução de Guilherme João de Freitas Teixeira; apresentação da edição brasileira, Gerd Bornheim. - Rio de janeiro: DP\&A, 2002.

SILVA, Alex Sander da. Fetichismo, alienação e educação como mercadoria. Revista Reflexão e Ação, Santa Cruz do Sul, v.19, n1, p.123-139, jan./jun. 2011. Disponível em: http://online.unisc.br/seer/index.php/reflex/article/view/1900.

SILVEIRA, Maria Laura. Território usado: dinâmicas de Especialização, dinâmicas de diversidade. Disponível em: http://www.agbbauru.org.br/publicacoes/revista/anoXV_1/AGB_dez2011_artigos_ver sao_internet/AGB_dez2011_01.pdf. Acesso em 5 de Julho de 2014.

0 território em pedaços. Disponível em:http://comciencia.scielo.br/scielo.php?script=sci_arttext\&pid=S151976542011000900007\&lng=pt\&nrm=iso. Acesso em: 7 de Julho de 2014.

SANTOS, Milton. A Natureza do Espaço. Técnica - Tempo, Razão e Emoção. 4를. 7 reimpr. - São Paulo: EDUSP, 2012. (1를. 1996).

Brasília: ABMES, 2000.

Ensino Superior público e particular e o território brasileiro.

SANTOS. MILTON. Da totalidade ao lugar. São Paulo: Editora da Universidade de São Paulo, 2005. 
Da totalidade ao lugar. - $1^{\underline{a}}$ Ed., 1. Reimpr.- São Paulo: Editora da Universidade de São Paulo, 2008.

Universidade de São Paulo, 2007.

O espaço do cidadão. - $7^{\underline{a}}$ Ed. São Paulo: Editora da

Técnica, espaço e Tempo. Globalização e Meio TécnicoCientífico-Informacional. São Paulo: Editora da Universidade de São Paulo, 2012.

SANTOS, M. \& SILVEIRA, M. L. O Brasil. Território e Sociedade no Início do século XXI. 11 ${ }^{\text {a }}$ ed. Rio de Janeiro: RECORD, 2008.

Brasília: ABMES, 2000.

Ensino Superior público e particular e o território brasileiro.

SANTAGADA, Salvatore. A educação profissional técnica de nível médio no Brasil e no Rio Grande do Sul. Carta de Conjuntura FEE, Porto Alegre, v.18, n. 7, p. 2, jul. 2009.

WINCKLER, Carlos Roberto; SANTAGADA, Salvatore. O Fundeb: novos horizontes para a Educação Básica? Indicadores Econômicos FEE, Porto Alegre, v. 35, n. 2, p. 39-46, 2007.

WINCKLER, Carlos Roberto; SANTAGADA, Salvatore. Ensino médio e desenvolvimento: um elo frágil. Indicadores Econômicos FEE, Porto Alegre, v. 36, n. 4, p. 65-78, 2009.

WINCKLER, Carlos Roberto; SANTAGADA, Salvatore. A educação profissional técnica de nível médio no Brasil: transição para um novo modelo?.( 2012). Disponível em: http://www.poa.ifrs.edu.br/wp-content/uploads/2012/03/263115865-1-PB.pdf. Acesso em 8 de Julho de 2015.

SANTAGADA, Salvatore. A educação profissional técnica de nível médio no Brasil e no Rio Grande do Sul. Carta de Conjuntura FEE, Porto Alegre, v.18, n. 7, p. 2, jul. 2009.

WINCKLER, Carlos Roberto; SANTAGADA, Salvatore. 0 Fundeb: novos horizontes para a Educação Básica? Indicadores Econômicos FEE, Porto Alegre, v. 35, n. 2, p. 39-46, 2007.

WINCKLER, Carlos Roberto; SANTAGADA, Salvatore. Ensino médio e desenvolvimento: um elo frágil. Indicadores Econômicos FEE, Porto Alegre, v. 36 ,

n. 4, p. 65-78, 2009.

WERMELINGER, Mônica; MACHADO, Maria Helena; AMÂNCIO FILHO, Antenor. Políticas de educação profissional: referências e perspectivas. Ensaio: avaliação e políticas públicas em educação, Rio de Janeiro, v. 15, n. 55, p. 207222, abr./jun. 2007. 
WERMELINGER, Mônica; MACHADO, Maria Helena; AMÂNCIO FILHO, Antenor. Políticas de educação profissional: referências e perspectivas. Ensaio: avaliação e políticas públicas em educação, Rio de Janeiro, v. 15, n. 55, p. 207222, abr./jun. 2007.

SAVIANI, Demerval. Pedagogia Histórico-Crítica: primeiras aproximações. 7 ed. Campinas, SP: Autores Associados, 2000.

O plano de Desenvolvimento da Educação: Análise do projeto do MEC. Educ. Soc., Campinas, vol. 28, n. 100 - Especial, p. 1231-1255, out. 2007. Disponível em http://www.cedes.unicamp.br. Acesso em 24 de Julho de 2016.

2011.

Educação em diálogo. Campinas, SP: Autores Associados,

O Plano de Desenvolvimento da Educação: análise do projeto do MEC. Educ. Soc., Campinas, vol. 28, n. 100 - Especial, p. 1231-1255, out. 2007. Disponível em http://www.cedes.unicamp.br Acesso: 30 de maio de 2015.

SEVERINO, Antonio J. Educação, trabalho e cidadania: a educação brasileira e o desafio da formação humana no atual cenário histórico. Disponível em: http://www.scielo.br/scielo.php?pid=S0102-88392000000200010\&script=sci arttext. Acesso: 7 de Julho de 2015.

SANTOS, Milton. A Natureza do Espaço. Técnica - Tempo, Razão e Emoção. 4를. 7 reimpr. - São Paulo: EDUSP, 2012. (1ª ed. 1996).

SANTOS. MILTON. Da totalidade ao lugar. São Paulo: Editora da Universidade de São Paulo, 2005.

Da totalidade ao lugar. - 1aㅡ Ed., 1. Reimpr.- São Paulo: Editora da Universidade de São Paulo, 2008.

Universidade de São Paulo, 2007.

O espaço do cidadão. - $7^{a}$ Ed. São Paulo: Editora da

Técnica, espaço e Tempo. Globalização e Meio TécnicoCientífico-Informacional. São Paulo: Editora da Universidade de São Paulo, 2012.

SANTOS, M. \& SILVEIRA, M. L. O Brasil. Território e Sociedade no Início do

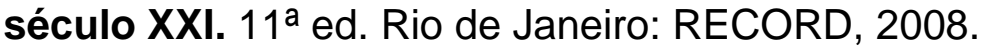

Brasília: ABMES, 2000.

Ensino Superior público e particular e o território brasileiro.

..Geografia e planejamento: o uso do território - geopolítica. Revista Eletrônica: Tempo - Técnica - Território, V.2, N.2 (2011), 1:49 ISSN: 21774366. 
SOUZA, Maria Adélia Aparecida de [et al.]. Território Brasileiro: usos e abusos. Campinas: Edições TERRITORIAL, 2003.

Aparecida de Souza In:

Apresentação: Milton Santos, um revolucionário por Maria Adélia

A metrópole e o futuro. A dinâmica dos lugares e o período popular da história In: SOUZA, Maria Adélia Aparecida. A metrópole e o futuro: Refletindo sobre Campinas. Campinas: Edições Territorial, 2008.

O lugar de todo o mundo: a Geografia da Solidariedade. Comunicação apresentada no Seminário organizado pelo Programa de PósGraduação e pelo Departamento de Geografia da UFBA, Bahia, Brasil, 1997.

O impacto da globalização e do ajuste econômico sobre o nível de emprego. Comunicação apresentada no Seminário: Plano Real e desemprego, organizado pela Fundação Pedroso Horta - Nacional, na Câmara Municipal de São Paulo, 1996.

Política e Território: a Geografia das Desigualdades. Texto elaborado para o FORUM Brasil em Questão, organizado pela Universidade de Brasília e apresentado na Mesa Redonda A DIVERSIDADE REGIONAL BRASILEIRA, no dia 05 de junho de 2002.

Apresentação Milton Santos, um revolucionário (2005) In: SANTOS, Milton. O retorno do Território. Disponível em: http://bibliotecavirtual.clacso.org.ar/ar/libros/osal/osal16/D16Santos.pdf. Acesso em: 20 de Junho de 2017.

SOUZA, Simone de (et al). Uma nova história do Ceará. - 2 ed. rev e atual. Fortaleza: Edições Demócrito Rocha, 2002.

SANTOS, M. \& SILVEIRA, M. L. O Brasil. Território e Sociedade no Início do

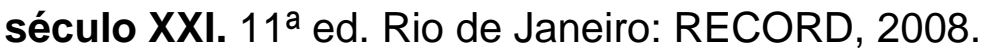

SANTOS, M. et al. O papel ativo da geografia um manifesto. Estudos Territoriais Brasileiros. São Paulo: Laboplan. FFLCH, USP, 2000.

SOARES NETO, Joaquim José; JESUS, Girlene R. de; KARINO, Camila A.; ANDRADE, Dalton $F$. de. Uma escala para medir a infraestrutura escolar. Disponível em: http://www.fcc.org.br/pesquisa/publicacoes/eae/arquivos/1786/1786.pdf. Acesso em: 4 de Julho de 2015.

SOUSA, Antonia de Abreu; OLIVEIRA, Elenilce G. de (orgs.). Educação Profissional: Análise contextualizada. Fortaleza: Edições UFC, 2014.

SILVA, José Borzacchiello. 0 algodão na organização do espaço In SOUZA, Simone de. História do Ceará. Fortaleza: Universidade do Ceará/Fundação Demócrito Rocha / Stylus Comunicações, 1989. 
SILVA, Alex Sander da. Fetichismo, alienação e educação como mercadoria. Revista Reflexão e Ação, Santa Cruz do Sul, v.19, n1, p.123-139, jan./jun. 2011. Disponível em: http://online.unisc.br/seer/index.php/reflex/article/view/1900.

SILVA, Cátia. A. da: Espaço, técnica e saber: labirintos da qualificação do trabalho. In Castro, Iná et al. (orgs.), Redescobrindo o Brasil: 500 anos depois, Rio de Janeiro, Bertrand Brasil, 1999.

TEODORO, Antônio [et al.] Tempos e Andamentos nas políticas de educação: estudos iberoamericanos. Brasília: Líber Livro Editora, CYTED, 2008.

TRANSPETRO. Relatório Anual, 2008. Disponível em: file://CC:/Users/JAQUELINE/Downloads/relat_rio_demonstra_es_2008_port_e_ing.p df

NOBRE, Leila. TRIBUNA DO CEARÁ. Escola Técnica Federal do Ceará (2011). Disponível em: http://www.fortalezanobre.com.br/search/label/Escola\%20T\%C3\%A9cnica\%20Feder al\%20do\%20Cear\%C3\%A1. Acesso em 21/09/2016.

UNESCO, Organização das Nações Unidas para a Educação, a Ciência e a Cultura. Declaração Mundial sobre Educação para Todos: satisfação das necessidades básicas de aprendizagem. Jomtien, 1990. Disponível em: http://unesdoc.unesco.org/images/0008/000862/086291por.pdf. Acesso em: 12 de Junho de 2015.

VASCONCELOS, Tereza S. Loiola. Reestruturação socioespacial do Ceará: os desdobramentos da modernização da agricultura no território do Perímetro Irrigado Baixo Acaraú. Dissertação apresentada ao Mestrado Acadêmico em Geografia, do Centro de Ciências e Tecnologia da Universidade Estadual do Ceará para obtenção do título de Mestre. Área de concentração: Análise Geoambiental Integrada e Ordenação do Território nas Regiões Semi-áridas e Litorâneas. Linha de Pesquisa: Sociedade, Espaço e Cultura sob a orientação do Prof. Dr. Luiz Cruz Lima, Ceará, 2010.

VIEIRA, Sofia Lerche; FARIAS, História da educação no Ceará: sobre promessas, feitos e fatos. Fortaleza: Edições Demócrito Rocha, 2002.

WINCKLER, Carlos Roberto; SANTAGADA, Salvatore. A educação profissional técnica de nível médio no Brasil: transição para um novo modelo?. Disponível em: $\quad$ http://www.poa.ifrs.edu.br/wp-content/uploads/2012/03/2631-15865-1-PB.pdf. Acesso em 8 de Julho de 2015.

ZANLORENSE, Maria Joselia. O contexto histórico de criação e instalação das escolas técnicas no paraná (1900-1950). Disponível em: http://www.histedbr.fe.unicamp.br/acer_histedbr/jornada/jornada11/artigos/10/artigo simposio_10_595_mjzanlorense@hotmail.com.pdf. Acesso em: 14 de setembro de 2016. 
ZIBAS, Dagmar, M. L.; FERRETTI, Celso, J.; TARTUCI, Gisela; LOBO, B. P. (2005). 0 protagonismo de alunos e pais no Ensino Médio brasileiro. Disponível em: http://redalyc.uaemex.mx/pdf/374/37418203.pdf. Acesso em 10 de Julho de 2015.

ZOMIGHANI JÚNIOR. James Humberto. Desigualdades espaciais e prisões na era da globalização neoliberal: fundamentos da insegurança no atual período. Tese apresentada ao Programa de Pós-Graduação em Geografia Humana da Faculdade de Filosofia, Letras Ciências Humanas da Universidade de São Paulo. Sob orientação da professora doutora Maria Adélia Aparecida de Souza. São Paulo, 2013.

\section{SITE VISITADOS}

Fundo Nacional do Desenvolvimento da Educação - FNDE, 2012. Histórico http://www.fnde.gov.br/financiamento/fundeb/fundeb-historico

Secretaria de educação do estado do Ceará SEDUC - 2015 http://www.educacaoprofissional.seduc.ce.gov.br/index.php?option=com_content\&vi ew $=$ article\&id $=3 \& \mid$ temid $=103$

http://www.educacaoprofissional.seduc.ce.gov.br/index.php?option=com_content\&vi ew $=$ article\&id $=40 \&$ Itemid $=150$ ).

Universidade da Integração da Lusofonia Afro-brasileira. Disponível em: http://www.unilab.edu.br/historia-de-redencao-liberdade/

DNOCS

Castanhão

http://www.dnocs.gov.br/php/comunicacao/noticias.php?f_registro=3474\&f_opcao=i mprimir\&p_view=short\&f_header $=1 \&$

http://www.dnocs.gov.br/ dnocs/doc/canais/perimetros_irrigados/ce/ico_lima_campo s.html

\section{IPEA}

http://www.ecodesenvolvimento.org/noticias/ipea-analisa-dados-sobre-educacao-nobrasil

http://www.clicrbs.com.br/especial/sc/portal-social/19,0,3117189,Ipea-analisasituacao-da-educacao-brasileira.html

atlas do desenvolvimento humano do brasil. Disponível em: http://www.atlasbrasil.org.br/2013/pt/perfil_uf/ceara\#educacao

http://www.clicrbs.com.br/pdf/9766016.pdf 


\section{IBGE}

http://seriesestatisticas.ibge.gov.br/series.aspx?vcodigo=PD384\&t=taxa-deanalfabetismo-funcional

http://www.emdialogo.uff.br/sites/default/files/sitese_de_indicadores_sociais_ibge.pdf

\section{NOTÍCIAS TERRA}

http://noticias.terra.com.br/educacao/unesco-aponta-ma-qualidade-como-principalproblema-da-educacao-no-

brasil,6a8520cd9b3d3410VgnCLD2000000dc6eb0aRCRD.html

http://noticias.terra.com.br/educacao/ibge-analfabetismo-cresce-pela-primeira-vezdesde-1998,e5e1e55448c51410VgnVCM3000009acceb0aRCRD.html.

\section{OECD/PISA}

http://www.oecd.org/pisa/keyfindings/PISA-2012-results-brazil.pdf

\section{SECRETARIA DE EDUCAÇÂO DO ESTADO DO CEARÁ - SEDUC/CE}

http://www.seduc.ce.gov.br

http://www.educacaoprofissional.seduc.ce.gov.br/index.php?option=com_content\&vi ew $=$ article\&id $=3 \&$ Itemid $=103$

\section{UNESCO}

http://www.unesco.org/new/pt/brasilia/about-this-office/single-

view/news/equity_and_quality_education_are_the_themes_of_the_education_for_all global_monitoring_report_20132014/\#.UwY1hGJdUge

\section{NOTÍCIAS TERRA}

http://noticias.terra.com.br/educacao/unesco-aponta-ma-qualidade-como-principalproblema-da-educacao-no-

brasil,6a8520cd9b3d3410VgnCLD2000000dc6eb0aRCRD.html

http://noticias.terra.com.br/educacao/ibge-analfabetismo-cresce-pela-primeira-vezdesde-1998,e5e1e55448c51410VgnVCM3000009acceb0aRCRD.html.

\section{MINISTÉRIO DA EDUCAÇÃO - MEC}

http://portal.mec.gov.br/seb/arquivos/pdf/blegais.pdf

http://portal.inep.gov.br/educacao-profissional 


\section{GOVERNO DO ESTADO DO CEARÁ}

http://www.ceara.gov.br/sala-de-imprensa/noticias/10353-porto-do-pecem-obras-deexpansao-do-tmut-estao-16-executadas

Orçamento

METROFOR http://www.camara.leg.br/internet/comissao/index/mista/orca/orcamento/OR2005/TC U/IGC/15453129553190004_0408.pdf

\section{MINISTÉRIO DA EDUCAÇÃO}

http://portal.mec.gov.br/pronatec/o-que-e

http://portal.mec.gov.br/index.php?option=com_content\&view=article\&id=12814\&ltem id $=872$ 
ANEXOS 
Anexo 1

\section{Constituições Brasileiras e a Educação}

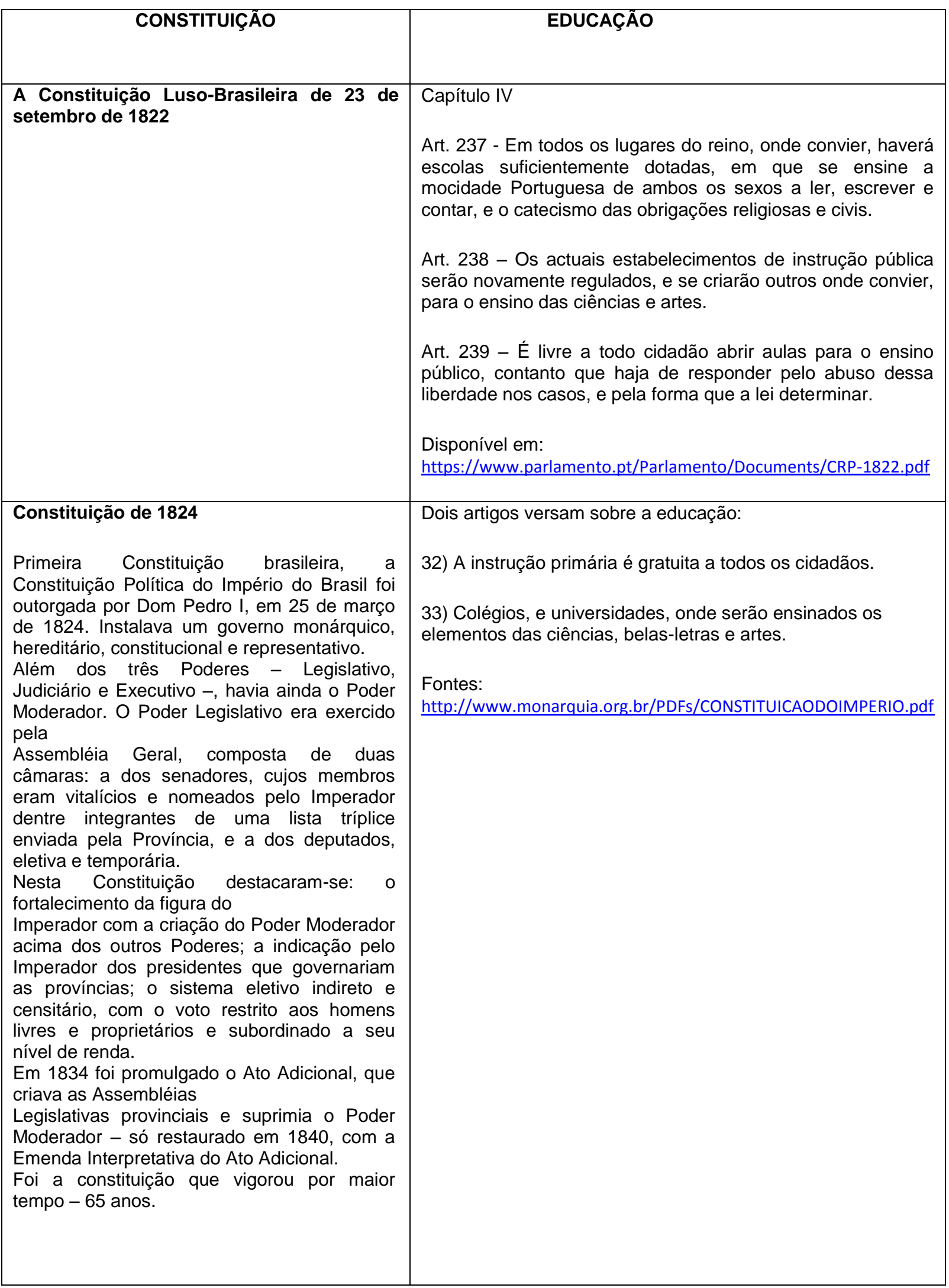




\begin{abstract}
Constituição de 1891
Foi promulgada pelo Congresso Constitucional, o mesmo que elegeu Deodoro da Fonseca Presidente. Tinha caráter liberal e federalista, inspirado na tradição republicana dos Estados Unidos. Instituiu o presidencialismo, concedeu grande autonomia aos estados da federação e garantiu a liberdade partidária. Estabeleceu eleições diretas para a Câmara, o Senado e a Presidência da República, com mandato de quatro anos. Estabeleceu o voto universal e não-secreto para homens acima de 21 anos e vetava o mesmo a mulheres, analfabetos, soldados e religiosos; determinou a separação oficial entre o Estado e a Igreja Católica; instituiu o casamento civil e o habeas corpus; aboliu a pena de morte e extinguiu o Poder Moderador. Também nesta Constituição ficou estabelecida, em seu artigo terceiro, uma zona de $14.400 \mathrm{Km} 2$ no Planalto Central, para a futura Capital Federal.

A Constituição de 1891 vigorou por 39 anos
\end{abstract}

\section{Constituição de 1934}

Foi promulgada pela Assembléia Constituinte no primeiro governo do Presidente Getúlio Vargas e preservou a essência do modelo liberal da Constituição anterior. Garantiu maior poder ao governo federal; instituiu o voto obrigatório e secreto a partir dos 18 anos e 0 voto feminino, já instituídos pelo Código Eleitoral de 1932; fixou um salário mínimo; introduziu a organização sindical mantida pelo Estado. Criou o mandado de segurança. Sob a rubrica "Da Ordem Econômica e Social", explicitava que deveria possibilitar "a todos existência digna" e sob a rubrica "Da família, da Educação e da Cultura" proclamava a educação "direito de todos". Mudou também o enfoque da democracia individualista para a democracia social. Estabeleceu os critérios acerca da criação da Justiça do Trabalho e da Justiça Eleitoral. O Poder Legislativo seria exercido pela Câmara dos Deputados com colaboração do Senado, sendo aquela constituída por representantes eleitos pela população e por organizações de caráter profissional e trabalhista.

A Constituição de 1934 vigorou por 3 anos.
Carta de 1891, no capítulo sobre a "Declaração dos Direitos". $\S$ 6으 Será leigo o ensino ministrado nos estabelecimentos publicos.

Art. 35. Incumbe, outrosim, ao Congresso, mas não privativamente:

10 Velar na guarda da Constituição e das leis, e providenciar sobre as necessidades de caracter federal;

$2^{\circ}$ Animar, no paiz, o desenvolvimento das lettras, artes e sciencias, bem como a immigração, a agricultura, a industria e o commercio, sem privilegios que tolham a acção dos governos locaes:

$3^{\circ}$ Crear instituições de ensino superior e secundario nos Estados;

4ํ- Prover á instrucção secundaria no Districto Federal.

http://www2.camara.leg.br/legin/fed/consti/1824-

1899/constituicao-35081-24-fevereiro-1891-532699publicacaooriginal-15017-pl.html

Art 137. A lei federal regulará a fiscalização e a revisão das tarifas dos serviços explorados por concessão, ou delegação, para que, no interesse coletivo, os lucros dos concessionarios, ou delegados, não excedam a justa retribuição do capital, que lhes permita atender normalmente ás necessidades publicas de expansão e melhoramento desses serviços.

Art 138. Incumbe á União, aos Estados e aos Municipios, nos termos das leis respectivas:

a) assegurar amparo aos desvalidos, criando serviços especializados e animando os serviços sociaes, cuja orientação procurarão coordenar;

b) estimular a educação eugenica;

Art. 148. Cabe à União, aos Estados e aos Municipios favorecer e animar o desenvolvimento das sciencias, das artes, das letras e da cultura em geral, proteger os objectos de interesse historico e o patrimonio artistico do paiz, bem como prestar assistencia ao trabalhador intellectual.

Art 149. A educação é direito de todos e deve ser ministrada, pela familia e pelos poderes publicos, cumprindo a estes proporcional-a a brasileiros e a estrangeiros domiciliados no paiz, de modo que possibilite efficientes factores da vida moral e economica da Nação, e desenvolva num espirito brasileiro a consciencia da solidariedade humana.

Art 150. Compete á União:

a) fixar o plano nacional de educação, comprehensivo do ensino de todos os graus e ramos, communs e especializados; e coordenar e fiscalizar a sua execução, em todo o território do paiz;

b) determinar as condições de reconhecimento official dos estabelecimentos de ensino secundario e complementar deste e dos institutos de ensino superior, exercendo sobre 
elles a necessaria fiscalização;

c) organizar e manter, nos Territorios, systemas educativos apropriados aos mesmos;

d) manter no Districto Federal ensino secundario e complementar deste, superior e universitario;

e) exercer acção supletiva, onde se faça necessaria, por deficiencia de iniciativa ou de recursos e estimular a obra educativa em todo o paiz, por meio de estudos, inqueritos, demonstrações e subvenções.

Paragrapho unico. O plano nacional de educação constante de lei federal, nos termos dos arts. 5, n. XIV, e 39, n. 8, letras a e $e$, só se poderá renovar em prazos determinados, e obedecerá ás seguintes normas:

a) ensino primario integral gratuito e de freqüencia obrigatoria extensivo aos adultos:

b) tendencia á gratuidade do ensino educativo ulterior ao primario, a fim de o tornar mais accessivel;

c) liberdade de ensino em todos os graus e ramos, observadas as prescripções da legislação federal e da estadual;

d) ensino, nos estabelecimentos particulares, ministrado no idioma patrio, salvo o de linguas estrangeiras;

e) limitação da matricula á capacidade didactica do estabelecimento e selecção por meio de provas de intelligencia e aproveitamento, ou por processos objectivos apropriados á finalidade do curso;

f) reconhecimento dos estabelecimentos particulares de ensino sómente quando assegurarem. a seus professores a estabilidade, enquanto bem servirem, e uma remuneração condigna.

Art 151. Compete aos Estados e ao Districto Federal organizar e manter systemas educativos nos territorios respectivos, respeitadas as directrizes estabelecidas pela União.

Art 152. Compete precipuamente ao Conselho Nacional de Educação, organizado na fórma da lei, elaborar o plano nacional de educação para ser approvado pelo Poder Legislativo e suggerir ao Governo as medidas que julgar necessarias para a melhor solução dos problemas educativos bem como a distribuição adequada dos fundos especiaes.

Paragrapho unico. Os Estados e o Disctrito Federal, na fórma das leis respectivas e para o exercicio da sua competencia na materia, estabelecerão Conselhos de Educação com funcções similares ás do Conselho Nacional de Educação e departamentos autonomos de administração do ensino.

Art 153. O ensino religioso será de freqüencia facultativa e ministrado de acôrdo com os principios da confissão religiosa do alumno, manifestada pelos paes ou responsaveis e constituirá materia dos horarios nas escolas publicas primarias, secundarias, profissionaes e normaes.

Art 154. Os estabelecimentos particulares de educação, gratuita primaria ou profissional, officialmente considerados idoneos, serão isentos de qualquer tributo. 
Art 155. É garantida a liberdade de cathedra.

Art 156. A União e os Municipios applicarão nunca menos de dez por cento, e os Estados e o Districto Federal nunca menos de vinte por cento, da renda resultante dos impostos na manutenção e no desenvolvimento dos systemas educativos.

Paragrapho unico. Para a realização do ensino nas zonas ruraes, a União reservará no minimo, vinte por cento das quotas destinadas á educação no respectivo orçamento annual.

Art 157. A União, os Estados e o Districto Federal reservarão uma parte dos seus patrimonios territoriaes para a formação dos respectivos fundos de educação.

$\S 1^{\circ}$ As sobras das dotações orçamentarias accrescidas das doações, percentagens sobre o producto de vendas de terras publicas, taxas especiaes e outros recursos financeiros, constituirão, na União, nos Estados e nos Municipios, esses fundos especiaes, que serão applicados exclusivamente em obras educativas, determinadas em lei.

§ 2ำ Parte dos mesmos fundos se applicará em auxilios a alumnos necessitados, mediante fornecimento gratuito de material escolar, bolsas de estudo, assistencia alimentar, dentaria e medica, e para villegiaturas.

Art 158. É vedada a dispensa do concurso de titulos e provas no provimento dos cargos do magisterio official, bem como, em qualquer curso, a de provas escolares de habilitação, determinadas em lei ou regulamento.

$\S 1^{\circ}$ Podem, todavia, ser contractados, por tempo certo, professores de nomeada, nacionaes ou estrangeiros.

$\S 2^{\circ}$ Aos professores nomeados por concurso para os institutos officiaes cabem as garantias de vitaliciedade e de inamovibilidade nos cargos, sem prejuízo do disposto no Título VII. Em casos de extincção da cadeira, será o professor aproveitado na regencia de outra, em que se mostre habilitado. 


\begin{tabular}{|c|c|}
\hline Constituição de 1937 & DA EDUCAÇAO E DA CULTURA \\
\hline $\begin{array}{l}\text { No início de novembro de } 1937 \text {, tropas da } \\
\text { polícia militar do Distrito Federal cercaram o } \\
\text { Congresso e impediram a entrada dos } \\
\text { parlamentares. No mesmo dia, Vargas } \\
\text { apresentou uma nova fase política e a entrada } \\
\text { em vigor de nova Carta Constitucional. } \\
\text { Começava oficialmente o "Estado Novo". Deu- } \\
\text { se a supressão dos partidos políticos e a } \\
\text { concentração de poder nas mãos do chefe } \\
\text { supremo. A Carta de } 1937 \text { possuía clara } \\
\text { inspiração nos modelos fascistas europeus, } \\
\text { institucionalizando o regime ditatorial do } \\
\text { Estado Novo. Ficaria conhecida como } \\
\text { "Polaca", devido a certas semelhanças com a } \\
\text { Constituição Polonesa de } 1935 \text {. } \\
\text { Extinguiu o cargo de vice-presidente, suprimiu } \\
\text { a liberdade político-partidária e anulou a } \\
\text { independência dos Poderes e a autonomia } \\
\text { federativa. } \\
\text { Essa Constituição permitiu a cassação da } \\
\text { imunidade parlamentar, a prisão e o exílio de } \\
\text { opositores. Instituiu a eleição indireta para } \\
\text { presidente da República, com mandato de seis } \\
\text { anos; a pena de morte e a censura prévia nos } \\
\text { meios de comunicação. Manteve os direitos } \\
\text { trabalhistas. } \\
\text { A Constituição de } 1937 \text { vigorou por oito anos. }\end{array}$ & 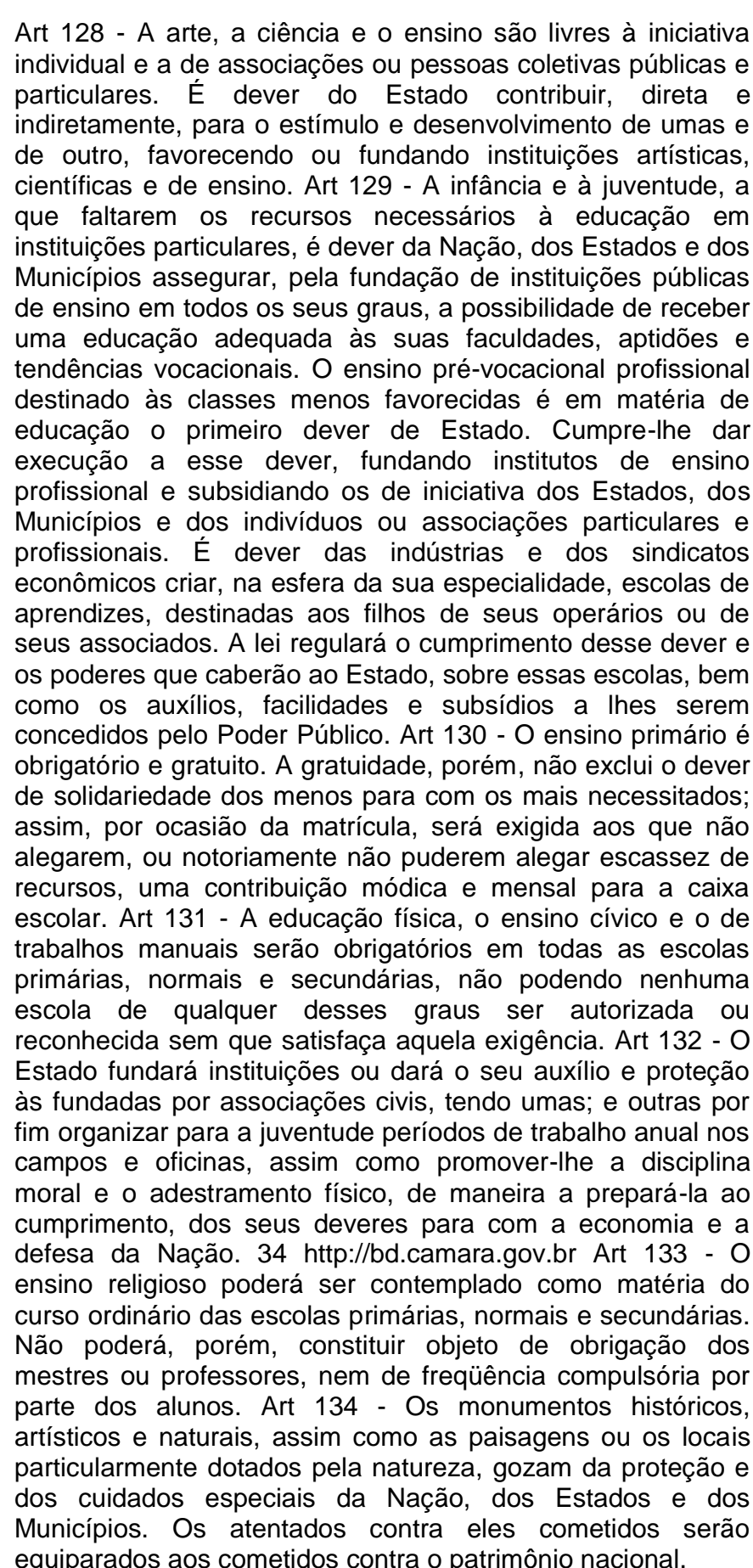 \\
\hline
\end{tabular}




\section{Constituição dos Estados Unidos do Brasil de 18 de setembro de 1946}

Promulgada durante o governo do presidente Eurico Gaspar Dutra, foi elaborada sob os auspícios da derrota dos regimes totalitários na Europa ao término da Segunda Guerra Mundial, refletia a redemocratização do Estado brasileiro.

Restabeleceu os direitos individuais, extinguindo a censura e a pena de morte. Devolveu a independência dos três poderes, a autonomia dos estados e municípios e a eleição direta para presidente da República, com mandato de cinco anos.

Em 1961 sofreu importante reforma com

a adoção do parlamentarismo. Foi posteriormente anulada pelo plebiscito de 1963, que restaurava o regime presidencialista.

A Constituição de 1946 vigorou por 21 anos.

\section{CAPÍTULO II}

Da Educação e da Cultura Art. 166 - A educação é direito de todos e será dada no lar e na escola. Deve inspirar-se nos princípios de liberdade e nos ideais de solidariedade humana. Art. 167 - O ensino dos diferentes ramos será ministrado pelos Poderes Públicos e é livre à iniciativa particular, respeitadas as leis que o regulem. Art. 168 - A legislação do ensino adotará os seguintes princípios: I - o ensino primário é obrigatório e só será dado na língua nacional; II - o ensino primário oficial é gratuito para todos; o ensino oficial ulterior ao primário sê- lo-á para quantos provarem falta ou insuficiência de recursos; III - as empresas industriais, comerciais e agrícolas, em que trabalhem mais de cem pessoas, são obrigadas a manter ensino primário gratuito para os seus servidores e os filhos destes; IV - as empresas industrias e comerciais são obrigadas a ministrar, em cooperação, aprendizagem aos seus trabalhadores menores, pela forma que a lei estabelecer, respeitados os direitos dos professores; V - o ensino religioso constitui disciplina dos horários das escolas oficiais, é de matrícula facultativa e será ministrado de acordo com a confissão religiosa do aluno, manifestada por ele, se for capaz, ou pelo seu representante legal ou responsável; VI - para o provimento das cátedras, no ensino secundário oficial e no superior oficial ou livre, exigirse-á concurso de títulos e provas. Aos professores, admitidos por concurso de títulos e provas, será assegurada a vitaliciedade; VII - é garantida a liberdade de cátedra. Art. 169 - Anualmente, a União aplicará nunca menos de dez por cento, e os Estados, o Distrito Federal e os Municípios nunca menos de vinte por cento da renda resultante dos impostos na manutenção e desenvolvimento do ensino. Art. 170 - A União organizará o sistema federal de ensino e o dos Territórios. Parágrafo único - O sistema federal de ensino terá caráter supletivo, estendendo-se a todo o País nos estritos limites das deficiências locais. Art. 171 - Os Estados e o Distrito Federal organizarão os seus sistemas de ensino. Parágrafo único Para o desenvolvimento desses sistemas a União cooperará com auxílio pecuniário, o qual, em relação ao ensino primário, provirá do respectivo Fundo Nacional. Art. 172 - Cada sistema de ensino terá obrigatoriamente serviços de assistência educacional que assegurem aos alunos necessitados condições de eficiência escolar. Art. 173 - As ciências, as letras e as artes são livres. 31 Art. 174 - O amparo à cultura é dever do Estado. Parágrafo único - A lei promoverá a criação de institutos de pesquisas, de preferência junto aos estabelecimentos de ensino superior. Art. 175 - As obras, monumentos e documentos de valor histórico e artístico, bem como os monumentos naturais, as paisagens e os locais dotados de particular beleza ficam sob a proteção do Poder Público. 
Constituição da república federativa do Brasil 24/01/1967

Foi promulgada pelo Congresso Nacional durante o governo Castelo Branco.

Oficializava e institucionalizava a ditadura do Regime Militar de 1964.

Foi por muitos denominada de "Super Polaca". Conservou o bipartidarismo criado pelo Ato Adicional $\mathrm{n}^{\circ} 2$.

Estabeleceu eleições indiretas, por meio do Colégio Eleitoral, para a presidência da República, com quatro anos de mandato.

Foram incorporadas nas suas Disposições Transitórias os dispositivos do Ato Institucional n 5 (Al-5), de 1968, dando permissão ao presidente para, dentre outros, fechar o Congresso, cassar mandatos e suspender direitos políticos. Permitiu aos governos militares total liberdade de legislar em matéria política, eleitoral, econômica e tributária. Desta forma, o Executivo acabou por substituir, na prática, o Legislativo e o Judiciário.

Sofreu algumas reformas como a emenda Constitucional no 1, de 1969, outorgada pela Junta Militar. Tal emenda se apresenta como um "complemento" às leis e regulamentações da Constituição de 1967. Embora seja denominada por alguns como Constituição, já que promulgou um texto reformulado a partir da Constituição de 1967, muitos são os que não a vêem como tal. A verdade é que, a partir desta emenda, ficam mais claras as características políticas da ditadura militar. Continuava em vigor o Ato Institucional no 5 e os demais atos institucionais anteriormente baixados.

A Constituição de 1967 autorizava a expedição de decretos-lei, a nomeação de senadores pelas Assembleias Legislativas, a prorrogação do mandato presidencial para seis anos e a alteração da proporcionalidade de deputados no Congresso.

A Constituição de 1967 vigorou por 21 anos.
Art 168 - A educação é direito de todos e será dada no lar e na escola; assegurada a igualdade de oportunidade, deve inspirar-se no princípio da unidade nacional e nos ideais de liberdade e de solidariedade humana.

$\S 1^{\circ}$ - O ensino será ministrado nos diferentes graus pelos Poderes Públicos.

$\S 2^{\circ}$ - Respeitadas as disposições legais, o ensino é livre à Iniciativa particular, a qual merecerá o amparo técnico e financeiro dos Poderes Públicos, inclusive bolsas de estudo.

$\S 3^{\circ}$ - A legislação do ensino adotará os seguintes princípios e normas:

I - o ensino primário somente será ministrado na língua nacional;

II - o ensino dos sete aos quatorze anos è obrigatório para todos e gratuito nos estabelecimentos primários oficiais;

III - o ensino oficial ulterior ao primário será, igualmente, gratuito para quantos, demonstrando efetivo aproveitamento, provarem falta ou insuficiência de recursos. Sempre que possível, o Poder Público substituirá o regime de gratuidade pelo de concessão de bolsas de estudo, exigido o posterior reembolso no caso de ensino de grau superior;

IV - o ensino religioso, de matrícula facultativa, constituirá disciplina dos horários normais das escolas oficiais de grau primário e médio.

V - o provimento dos cargos iniciais e finais das carreiras do magistério de grau médio e superior será feito, sempre, mediante prova de habilitação, consistindo em concurso público de provas e títulos quando se tratar de ensino oficial;

VI - é garantida a liberdade de cátedra.

Art 169 - Os Estados e o Distrito Federal organizarão os seus sistemas de ensino, e, a União, os dos Territórios, assim como o sistema federal, o qual terá caráter supletivo e se estenderá a todo o País, nos estritos limites das deficiências locais.

§ 1ํ - A União prestará assistência técnica e financeira para o desenvolvimento dos sistemas estaduais e do Distrito Federal.

§ $2^{\circ}$ - Cada sistema de ensino terá, obrigatoriamente, serviços de assistência educacional que assegurem aos alunos necessitados condições de eficiência escolar.

Art. 170 - As empresas comerciais, industriais e agrícolas são obrigadas a manter, pela forma que a lei estabelecer, o ensino primário gratuito de seus empregados e dos filhos destes. 


\begin{tabular}{|c|c|}
\hline & $\begin{array}{l}\text { ainda obrigadas a ministrar, em cooperação, aprendizagem } \\
\text { aos seus trabalhadores menores. } \\
\text { Art } 171 \text { - As ciências, as letras e as artes são livres. } \\
\text { Parágrafo único - O Poder Público incentivará a pesquisa } \\
\text { científica e tecnológica. } \\
\text { Art } 172 \text { - O amparo à cultura é dever do Estado. } \\
\text { Parágrafo único - Ficam sob a proteção especial do Poder } \\
\text { Público os documentos, as obras e os locais de valor histórico } \\
\text { ou artístico, os monumentos e as paisagens naturais notáveis, } \\
\text { bem como as jazidas arqueológicas. }\end{array}$ \\
\hline 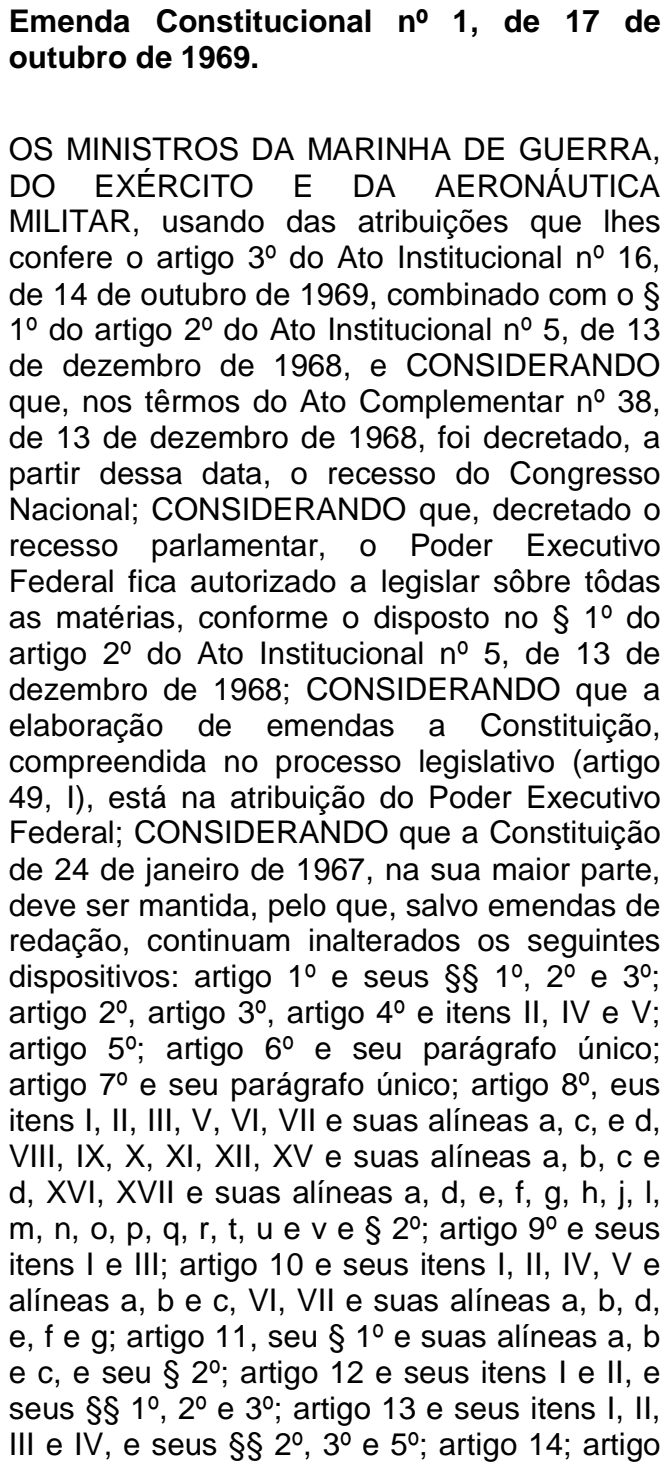 & 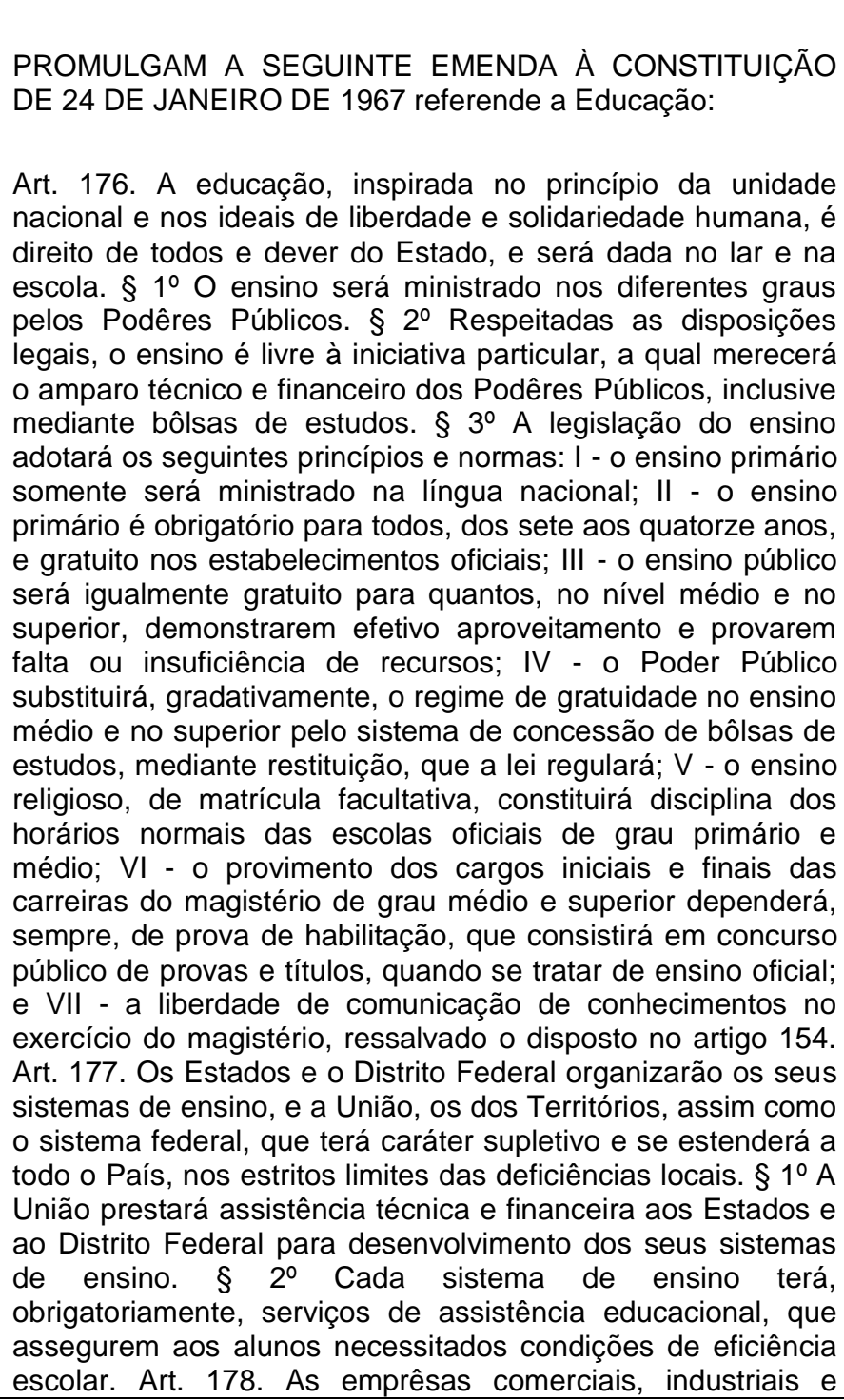 \\
\hline
\end{tabular}


15; artigo 16, seu item II e suas alíneas a e b, e seus $\S \S 10$ e suas alíneas a e b, $3^{\circ}$ e suas alíneas a e b, e $5^{\circ}$; artigo 17 e seus $\S \S 1^{\circ}$ e $3^{\circ}$; artigo 19 e seus itens I e II, e seus $\S \S 1^{\circ}, 2^{\circ}$, $4^{\circ}, 5^{\circ}$ e 6우 ; artigo 20 e seus itens I e III e seus alíneas a, b, c e d; artigo 21 e seus itens I, II e III; artigo 22 e seus itens III, VI e VII, e seus $\S \S$ $1^{\circ}$ e $4^{\circ}$; artigo 23; artigo 24 e seu $\S 7^{\circ}$; artigo 25 e seus itens I e II, e seus $\S \S 1^{\circ}$, alínea a, e 2; § $3^{\circ}$ do artigo 26; artigo 28 e seus itens I, II e III, e seu parágrafo único e alíneas a e b; artigo 30; § 3ำ do artigo 31; artigo 33; § 5응 do artigo 34; artigo 36 e seus itens I, alíneas a e b, e II, alíneas a, b, c e d; artigo 37 e seu item I; $\S 2$ do artigo 38; artigo 39; $\S 1^{\circ}$ e 20 do artigo 40; $\S 1^{\circ}$ do artigo 41; artigo 42 e seus itens I e II; $\S \S 1^{\circ}$ e $2^{\circ}$ do artigo 43; artigo 44, seus itens I e II, e seu parágrafo único; itens III, IV e V do artigo 45; artigo 46 e seus itens I, II, V, VII e VIII; artigo 47 e seus itens I, II, III, IV, V, VI e VIII; artigo 48; artigo 49 e seus itens I a VII; artigo 50 e seus itens I e II, e seus $\S \S$ 1ㅇ e 20; artigo 52; artigo 53; artigo 54 e seus $\S \S 2^{\circ}, 3^{\circ}$ e $5^{\circ}$; artigo 55 e seu parágrafo único e item I; artigo 56; artigo 57 e seu parágrafo único; artigo 58 e seu item I, e seu parágrafo único; artigo 59 e seu parágrafo único; artigo 60 e seus itens I, II e III, e seu parágrafo único e alíneas a e b; artigo 61 e seus $\S \S 1^{\circ}$ e $2^{ }$; ; $\S$ $4^{\circ}$ e $5^{\circ}$ do artigo 62; artigo 63 e seu item I e seu parágrafo único; artigo 64 e alíneas b e c de seu $\S 1^{\circ}$, e seu $\S 2^{\circ}$; $\S \S 1^{\circ}$ e $5^{\circ}$ artigo 65 ; artigo 67 e seu $\S 11^{\circ} ; \S 4^{\circ}$ do artigo 68; artigo 69 e seu $\S 2^{\circ}$ e alíneas a, b e c; artigo 71 e seus parágrafos; artigo 72 e seus itens I, II e III; artigo 73 e seus $\S \S 1^{\circ}, 2^{\circ}$, $3^{\circ}$ e $4^{\circ}$, alíneas a, b, e c do $\S 5^{\circ}$, e $\S \S 6^{\circ}, 7^{\circ}$ e $8^{\circ}$; artigo $74 ; \S$ $3^{\circ}$ do artigo 76; artigo 77 e seus $\S \S 1^{\circ}$ e $2^{\circ}$; artigo 78 e seus $\S \S 1^{\circ}$ e $2^{\circ}$; artigo 79 caput; artigo 80; artigo 81; artigo 82; artigo 83 e seus itens I, II, III, IV, V, VII, VIII, IX, X, XI, XII, XIII, XIV, XV, XVI, XVII, XVIII e XIX; artigo 84 seus itens I a VII, e seu parágrafo único; artigo 85 e seus parágrafos; artigo 87 e seus itens I, II e III; artigo 89; artigo 90 e seu $\S 2^{\circ}$; artigo 91 e alíneas $a, b$ e $c$ do item II e III, e parágrafo único; artigo 92 e seus $\S \S 1^{\circ}$ e $2^{\circ}$; artigo 93 e seu parágrafo único; artigo 94 e seus $\S \S 1^{\circ} \mathrm{e}$ $3^{\circ}$; artigo 95 e seu $\S 2^{\circ}$; artigo 96; artigo 97 e seus itens I a IV, e seus $\S \S 1^{\circ}$ a $3^{\circ}$; artigo 99, caput;artigo 100 e seus itens I, II e III e seu $\S$ 1; artigo 101 e seus itens I, alíneas a e b, II, e seus $\S \S 1^{\circ}$, 2ำ e $3^{\circ} ; \S 2^{\circ}$ do artigo 102; artigo 103 e seus itens I e II, e seu parágrafo único; artigo 105 e seu parágrafo único; artigo 107 e seus itens I a V; artigo 108 e seus itens I e II e 2 seus $\S \S 1^{\circ}$ e $2^{\circ}$; artigo 109 e seus itens I, II e III; artigo 110 e seus itens I, II e III; artigo 111; artigo 112 e seus $\S \S 1^{\circ}$ e $2^{\circ}$; artigo 114 e seu item I, alíneas f, g, j, I, m e n, item II, alínea c, alíneas a, b e c do item III; artigo 115 e seu parágrafo único e alíneas $a, b, c$ e d; artigo 116 e seu $\S 2^{\circ}$; artigo117 e seu item I, alíneas a e c, item II e parágrafo único; artigo 119 e seus itens III, IV, V, VI, VII, IX e X, e seus $\S \S$ $1^{\circ}$ e 20; artigo 120; artigo 121, alíneas a e b de seu $\S 1^{\circ}$, e seu $\S 2^{\circ}$; artigo 122 e seus $\S \S 1^{\circ}$, agrícolas são obrigadas a manter o ensino primário gratuito de seus empregados e o ensino dos filhos dêstes, entre os sete e os quatorze anos, ou a concorrer para aquêle fim, mediante a contribuição do salário-educação, na forma que a lei estabelecer. 49 Parágrafo único. As emprêsas comerciais e indústriais são ainda obrigadas a assegurar, em cooperação, condições de aprendizagem aos seus trabalhadores menores e a promover o preparo de seu pessoal qualificado. Art. 179. As ciências, as letras e as artes são livres, ressalvado o disposto no parágrafo $8^{\circ}$ do artigo 153. Parágrafo único. O Poder Público incentivará a pesquisa e o ensino científico e tecnológico. Art. 180. O amparo à cultura é dever do Estado. Parágrafo único. Ficam sob a proteção especial do Poder Público os documentos, as obras e os locais de valor histórico ou artístico, os monumentos e as paisagens naturais notáveis, bem como as jazidas arqueológicas. 
$2^{\circ}$ e $3^{\circ}$; artigo 123 e seus itens I a IV, e seu parágrafo único; item II do artigo 124 e alínea b do seu item I; artigo 125; artigo 126 e seus itens I, alíneas a e b, II, III, e seus $\S \S 1^{\circ}$ e e 2웅 artigo 127; artigo 129; artigo 130 e seus itens I a VIII; artigo 131 e seus itens I a IV; artigo 133 e seus itens, seu $\S 1^{\circ}$, alíneas a e b, e seus $\S \S$

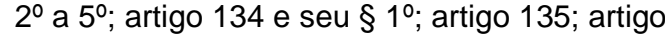
136 e seus itens I, II, alínea b, III, IV, seu $\S 1^{\circ}$ e alíneas a, b e c, e seus $\S \S 2^{\circ}$ e 6ㅇ; artigo 137; § 1ํ do artigo 138; artigo 139; artigo 140 e seus itens I, alíneas a, b e c, e II, alíneas a e b e números 1, 2 e 3; artigo 141 e seus itens I, II e III; artigo 142 e seus $\S \S 1^{\circ}, 2^{\circ}$ e $3^{\circ}$, alíneas a, b e c do item II do artigo 144; artigo 145 e seu parágrafo único e alíneas $a, b$ e c; artigo 149 e seus itens I, II, III, IV, V, VI e VIII; artigo 150 e seus $\S \S 1^{\circ}$ a $7^{\circ}$, 9ㅇ e 10,12 a 17,19 e 20, 23 a 27, 30 a 32, 34 e 35; artigo 152 e seus itens I e II, e seus $\S \S 1^{\circ}, 2^{\circ}$, alíneas a a f e 3; artigo 153 e seu $\S 1$ ㅇ; artigo 154; artigo 155; artigo 156; itens I, II, III, IV e VI do artigo 157 e seus $\S \S 2^{\circ}$, $3^{\circ}, 5^{\circ}, 7^{\circ}$, $8^{\circ}$, $9^{\circ}$ e e 10; artigo 158 e seus itens I a XV e XVIII a XXI, e seu $\S$ 1ㅇ; artigo 159 e seus $\S \S 1^{\circ}$ e $2^{\circ}$; artigo 160 e seus itens I, II e III; artigo 161 e seus $\S \S$ I a IV; artigo 162; artigo 163 e seus $\S \S 1$ e $3^{\circ}$; artigo 164 e seu parágrafo único; artigo 165 e seu parágrafo único; artigo 166 e seus itens I, II e III, e seus $\S \S 1^{\circ}$ e $2^{\circ}$; artigo 167 e seus $\S \S 1^{\circ}$, $2^{\circ}$ e $3^{\circ}$; $\S \S 1^{\circ}$, $2^{\circ}$ e $3^{\circ}$, seus itens I a V, do artigo 168; artigo 169 e seus $\S \S 1$ e e 2 ; parágrafo único do artigo 170; artigo 171 e seu parágrafo único; e artigo 172 e seu parágrafo único; CONSIDERANDO as emendas modificativas e supressivas que, por esta forma, são ora adotadas quanto aos demais dispositivos da Constituição, bem como as emendas aditivas que nela são introduzidas; CONSIDERANDO que, feitas as modificações mencionadas, tôdas em caráter de Emenda, a Constituição poderá ser editada de acôrdo com o texto que adiante se publica. 


Constituição de $\mathbf{1 9 8 8}$
Promulgada no governo de José Sarney. Foi
elaborada por uma Assembléia Constituinte,
legalmente convocada e eleita e a primeira a
permitir a incorporação de emendas
populares.

O Presidente da Assembléia Nacional Constituinte, Ulysses Guimarães, ao entregála à nação, chamou-a de "Constituição Cidadã".

Seus pontos principais são a República representativa, federativa e presidencialista. Os direitos individuais e as liberdades públicas são ampliados e fortalecidos. É garantida a inviolabilidade do direito à vida, à liberdade, à igualdade, à segurança e à propriedade. O Poder Executivo mantém sua forte influência, permitindo a edição de medidas provisórias com força de lei (vigorantes por um mês, passíveis de serem reeditadas enquanto não forem aprovadas ou rejeitadas pelo Congresso). O voto se torna permitido e facultativo a analfabetos e maiores de 16 anos. A educação fundamental é apresentada como obrigatória, universal e gratuita.

Também são abordados temas como o dever da defesa do meio ambiente e de preservação de documentos, obras e outros bens de valor histórico, artístico e cultural, bem como os sítios arqueológicos.

Reformas constitucionais começaram a ser votadas pelo Congresso Nacional a partir de 1992. Algumas das principais medidas abrem para a iniciativa privada atividades antes restritas à esfera de ação do Estado, esvaziando, de certa forma, o poder e a influência estatais em determinados setores. A iniciativa privada, nacional ou internacional, recebe autorização para explorar a pesquisa, a lavra e a distribuição dos derivados de petróleo, as telecomunicações e o gás encanado. As empresas estrangeiras adquirem o direito de exploração dos recursos minerais e hídricos.

$\mathrm{Na}$ esfera política ocorrem mudanças na organização e regras referentes ao sistema eleitoral; o mandato do presidente da República é reduzido de cinco para quatro anos e, em 1997, é aprovada a emenda que permite a reeleição do presidente da República, de governadores e prefeitos. Os candidatos processados por crime comum não podem ser eleitos, e os parlamentares submetidos a processo que possa levar à perda de mandato e à inelegibilidade não podem renunciar para impedir a punição.

Até o momento a Constituição de 1988 já sofreu alterações 45 vezes, com emendas constitucionais versando sobre os mais variados temas.

\section{SEÇÃO I \\ Da Educação}

Art. 205. A educação, direito de todos e dever do Estado e da família, será promovida e incentivada com a colaboração da sociedade, visando ao pleno desenvolvimento da pessoa, seu preparo para o exercício da cidadania e sua qualificação para o trabalho.

Art. 206. O ensino será ministrado com base nos seguintes princípios: I - igualdade de condições para o acesso e permanência na escola; II - liberdade de aprender, ensinar, pesquisar e divulgar o pensamento, a arte e o saber; III pluralismo de idéias e de concepções pedagógicas, e coexistência de instituições públicas e privadas de ensino; IV gratuidade do ensino público em estabelecimentos oficiais; V valorização dos profissionais do ensino, garantido, na forma da lei, plano de carreira para o magistério público, com piso salarial profissional e ingresso exclusivamente por concurso público de provas e títulos, assegurado regime jurídico único para todas as instituições mantidas pela União; VI - gestão democrática do ensino público, na forma da lei; VII - garantia de padrão de qualidade.

Art. 207. As universidades gozam de autonomia didáticocientífica, administrativa e de gestão financeira e patrimonial, e obedecerão ao princípio de indissociabilidade entre ensino, pesquisa e extensão.

Art. 208. O dever do Estado com a educação será efetivado mediante a garantia de: I - ensino fundamental, obrigatório e gratuito, inclusive para os que a ele não tiveram acesso na idade própria; II - progressiva extensão da obrigatoriedade e gratuidade ao ensino médio; III - atendimento educacional especializado aos portadores de deficiência, preferencialmente na rede regular de ensino; IV - atendimento em creche e pré-escola às crianças de zero a seis anos de idade; $\mathrm{V}$ - acesso aos níveis mais elevados do ensino, da pesquisa e da criação artística, segundo a capacidade de cada um; VI - oferta de ensino noturno regular, adequado às condições do educando; VII - atendimento ao educando, no ensino fundamental, através de programas suplementares de material didático-escolar, transporte, alimentação e assistência à saúde.

$\S 1^{\circ} \mathrm{O}$ acesso ao ensino obrigatório e gratuito é direito público subjetivo.

$\S 2$ 응 não-oferecimento do ensino obrigatório pelo poder público, ou sua oferta irregular, importa responsabilidade da autoridade competente.

$\S$ 3ํㅡㄹ Compete ao poder público recensear os educandos no ensino fundamental, fazer-Ihes a chamada e zelar, junto aos pais ou responsáveis, pela frequência à escola.

Art. 209. O ensino é livre à iniciativa privada, atendidas as seguintes condições: I - cumprimento das normas gerais da educação nacional; II - autorização e avaliação de qualidade pelo poder público.

Art. 210. Serão fixados conteúdos mínimos para o ensino fundamental, de maneira a assegurar formação básica comum e respeito aos valores culturais e artísticos, nacionais e regionais.

$\S 1^{\circ} \mathrm{O}$ ensino religioso, de matrícula facultativa, constituirá disciplina dos horários normais das escolas públicas de ensino fundamental.

$\S 2^{\circ} \mathrm{O}$ ensino fundamental regular será ministrado em língua 
portuguesa, assegurada às comunidades indígenas também a utilização de suas línguas maternas e processos próprios de aprendizagem.

Art. 211. A União, os Estados, o Distrito Federal e os Municípios organizarão em regime de colaboração seus sistemas de ensino.

§ 1ำ A União organizará e financiará o sistema federal de ensino e o dos Territórios, e prestará assistência técnica e financeira aos Estados, ao Distrito Federal e aos Municípios para o desenvolvimento de seus sistemas de ensino e o atendimento prioritário à escolaridade obrigatória.

$\S 2^{\circ}$ Os Municípios atuarão prioritariamente no ensino fundamental e pré-escolar.

Art. 212. A União aplicará, anualmente, nunca menos de dezoito, e os Estados, o Distrito Federal e os Municípios vinte e cinco por cento, no mínimo, da receita resultante de impostos, compreendida a proveniente de transferências, na manutenção e desenvolvimento do ensino.

$\S 1^{\circ}$ A parcela da arrecadação de impostos transferida pela União aos Estados, ao Distrito Federal e aos Municípios, ou pelos Estados aos respectivos Municípios, não é considerada, para efeito do cálculo previsto neste artigo, receita do governo que a transferir.

$\S 2$ - Para efeito do cumprimento do disposto no caput deste artigo, serão considerados os sistemas de ensino federal, estadual e municipal e os recursos aplicados na forma do art. 213.

§ $3^{0}$ A distribuição dos recursos públicos assegurará prioridade ao atendimento das necessidades do ensino obrigatório, nos termos do plano nacional de educação.

$\S 4^{\circ}$ Os programas suplementares de alimentação e assistência à saúde previstos no art. 208, VII, serão financiados com recursos provenientes de contribuições sociais e outros recursos orçamentários.

§ 5ㅇ - ensino fundamental público terá como fonte adicional de financiamento a contribuição social do salário-educação, recolhida, na forma da lei, pelas empresas, que dela poderão deduzir a aplicação realizada no ensino fundamental de seus empregados e dependentes.

Art. 213. Os recursos públicos serão destinados às escolas públicas, podendo ser dirigidos a escolas comunitárias, confessionais ou filantrópicas, definidas em lei, que: I comprovem finalidade não lucrativa e apliquem seus excedentes financeiros em educação; II - assegurem a destinação de seu patrimônio a outra escola comunitária, filantrópica ou confessional, ou ao poder público, no caso de encerramento de suas atividades.

$\S 1^{\circ}$ Os recursos de que trata este artigo poderão ser destinados a bolsas de estudo para o ensino fundamental e médio, na forma da lei, para os que demonstrarem insuficiência de recursos, quando houver falta de vagas e cursos regulares da rede pública na localidade da residência do educando, ficando o poder público obrigado a investir prioritariamente na expansão de sua rede na localidade.

$\S 2^{\circ}$ As atividades universitárias de pesquisa e extensão poderão receber apoio financeiro do poder público.

Art. 214. A lei estabelecerá o plano nacional de educação, de duração plurianual, visando à articulação e ao desenvolvimento do ensino em seus diversos níveis e à integração das ações do poder público que conduzam à: I erradicação do analfabetismo; II - universalização do atendimento escolar; III - melhoria da qualidade do ensino; IV - formação para o trabalho; V - promoção humanística, 


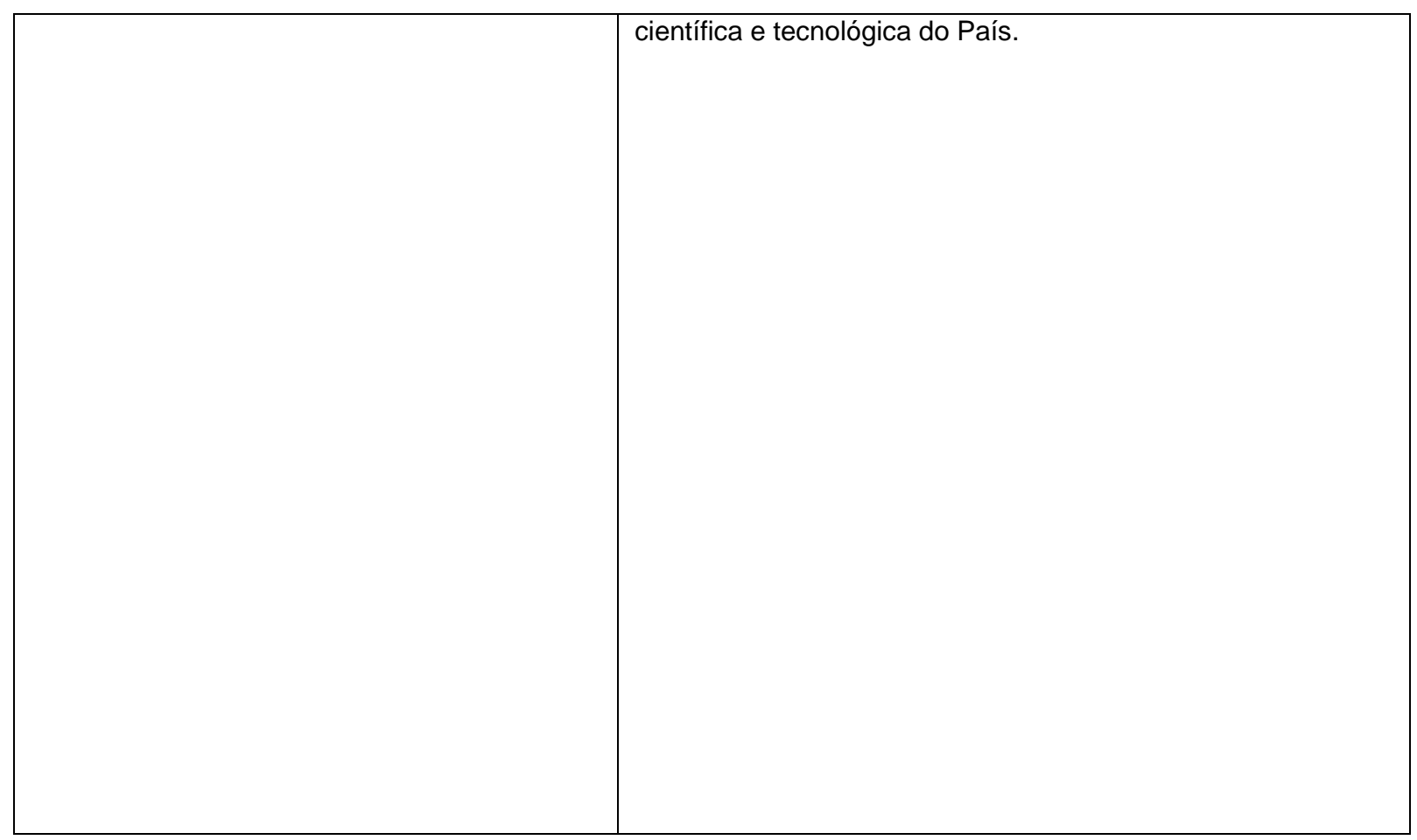

\section{Referências}

Constituições brasileiras: - Brasília: Câmara dos Deputados, Coordenação de Publicações, 2005.16 p. : il. - (Série cadernos do Museu ; n. 4) Exposição organizada pelo Museu da Câmara dos Deputados, mostrando as constituições brasileiras, suas principais deliberações e curiosidades.ISBN1.Constituição, exposição, Brasil. I. Brasil. Congresso. Câmara dos Deputados. Seção de Museu. II. Série.

\section{Sites Visitados}

http://www2.camara.leg.br/legin/fed/consti/1930-1939/constituicao-1934-16-

julho-1934-365196-publicacaooriginal-1-pl.html

http://www.politize.com.br/constituicao-de-1967/

http://www.planalto.gov.br/ccivil_03/constituicao/constituicao.htm

file://C:/Users/JAQUELINE/Downloads/constituicao_1937_texto.pdf 


\title{
Anexo 2
}

\section{Cursos técnicos por eixos}

\author{
AMBIENTE E SAÚDE \\ Técnico em Agente Comunitário de Saúde \\ Técnico em Análises Clínicas \\ Técnico em Citopatologia \\ Técnico em Controle Ambiental \\ Técnico em Cuidados de Idosos \\ Técnico em Enfermagem \\ Técnico em Equipamentos Biomédicos \\ Técnico em Estética \\ Técnico em Farmácia \\ Técnico em Gerência de Saúde \\ Técnico em Hemoterapia \\ Técnico em Imagem Pessoal \\ Técnico em Imobilizações ortopédicas \\ Técnico em Massoterapia \\ Técnico em Meio Ambiente \\ Técnico em Meteorologia \\ Técnico em Necropsia \\ Técnico em Nutrição e Dietética \\ Técnico em Óptica \\ Técnico em Órteses e Próteses \\ Técnico em Podologia \\ Técnico em Prótese Dentária \\ Técnico em Radiologia \\ Técnico em Reabilitação de Dependentes Químicos \\ Técnico em Reciclagem \\ Técnico em Registros e Informações em Saúde \\ Técnico em Saúde Bucal \\ Técnico em Vigilância em Saúde \\ CONTROLE E PROCESSOS INDUSTRIAIS
}

Técnico em Automação Industrial

Técnico em Eletroeletrônica

Técnico em Eletromecânica

Técnico em Eletrônica

Técnico em Eletrotécnica

Técnico em Manutenção Automotiva

Técnico em Manutenção de Aeronaves em Aviônicos

Técnico em Manutenção de Aeronaves em Célula

Técnico em Manutenção de Aeronaves em Grupo Motopropulsor

Técnico em Manutenção de Máquinas Industriais

Técnico em Manutenção de Máquinas Navais

Técnico em Manutenção de Máquinas Pesadas 
Técnico em Manutenção de Sistemas Metroferroviários

Técnico em Mecânica

Técnico em Mecânica de Precisão

Técnico em Mecatrônica

Técnico em Metalurgia

Técnico em Metrologia

Técnico em Processamento da Madeira

Técnico em Refrigeração e Climatização

Técnico em Sistemas a Gás

Técnico em Sistemas de Energia Renovável

Técnico em Soldagem

DESENVOLVIMENTO EDUCACIONAL E SOCIAL

Técnico em Alimentação Escolar

Técnico em Biblioteconomia

Técnico em Infraestrutura Escolar

Técnico em Laboratório de Ciências da Natureza

Técnico em Ludoteca

Técnico em Multimeios Didáticos

Técnico em orientação Comunitária

Técnico em Produção de Materiais Didáticos Bilíngues em Libras/Língua

Portuguesa

Técnico em Secretaria Escolar

Técnico em Tradução e Interpretação de Libras

Técnico em Treinamento e Instrução de Cães-Guias

\section{GESTÃO E NEGÓCIOS}

Técnico em Administração

Técnico em Comércio

Técnico em Comércio Exterior

Técnico em Condomínio

Técnico em Contabilidade

Técnico em Cooperativismo

Técnico em Finanças

Técnico em Logística

Técnico em Marketing

Técnico em Qualidade

Técnico em Recursos Humanos

Técnico em Secretariado

Técnico em Seguros

Técnico em Serviços Jurídicos

Técnico em Serviços Públicos

Técnico em Transações Imobiliárias

Técnico em Vendas

INFORMAÇÃO E COMUNICAÇÃO

Técnico em Computação Gráfica 
Técnico em Desenvolvimento de Sistemas

Técnico em Informática

Técnico em Informática para Internet

Técnico em Manutenção e Suporte em Informática

Técnico em Programação de Jogos Digitais

Técnico em Redes de Computadores

Técnico em Sistemas de Comutação

Técnico em Sistemas de Transmissão

Técnico em Telecomunicações

INFRAESTRUTURA

Técnico Aeroportuário

Técnico em Agrimensura

Técnico em Carpintaria

Técnico em Desenho de Construção Civil

Técnico em Edificações

Técnico em Estradas

Técnico em Geodésia e Cartografia

Técnico em Geoprocessamento

Técnico em Hidrologia

Técnico em Portos

Técnico em Saneamento

Técnico em Trânsito

Técnico em Transporte Aquaviário

Técnico em Transporte de Cargas

Técnico em Transporte Dutoviário

Técnico em Transporte Metroferroviário

Técnico em Transporte Rodoviário

MILITAR

Técnico em Ações de Comandos

Técnico em Armamento de Aeronaves

Técnico em Artilharia Antiaérea

Técnico em Artilharia

Técnico em Bombeiro Aeronáutico

Técnico em Cavalaria

Técnico em Combate a Incêndio, Resgate e Prevenção de Acidentes de

Aviação

Técnico em Comunicações Aeronáuticas

Técnico em Comunicações Navais

Técnico em Controle de Tráfego Aéreo

Técnico em Desenho Militar

Técnico em Eletricidade e Instrumentos Aeronáuticos

Técnico em Equipamento de Engenharia

Técnico em Equipamentos de Voo

Técnico em Estrutura e Pintura de Aeronaves

Técnico em Forças Especiais

Técnico em Fotointeligência 
Técnico em Guarda e Segurança

Técnico em Hidrografia

Técnico em Infantaria

Técnico em Informações Aeronáuticas

Técnico em Manobras e Equipamentos de Convés

Técnico em Material Bélico

Técnico em Mecânica de Aeronaves

Técnico em Mergulho

Técnico em Montanhismo

Técnico em Navegação Fluvial

Técnico em operação de Radar

Técnico em operação de Sonar

Técnico em operações de Engenharia Militar

Técnico em Preparação Física e Desportiva Militar

Técnico em Sensores de Aviação

Técnico em Sinais Navais

Técnico em Sinalização Náutica

Técnico em Suprimento

\section{PRODUÇÃO ALIMENTÍCIA}

Técnico em Agroindústria

Técnico em Alimentos

Técnico em Apicultura

Técnico em Cervejaria

Técnico em Confeitaria

Técnico em Panificação

Técnico em Processamento de Pescado

Técnico em Viticultura e Enologia

\section{PRODUÇÃO CULTURAL E DESIGN}

Técnico em Artes Circenses

Técnico em Artes Visuais

Técnico em Artesanato

Técnico em Canto

Técnico em Cenografia

Técnico em Composição e Arranjo

Técnico em Comunicação Visual

Técnico em Conservação e Restauro

Técnico em Dança

Técnico em Design de Calçados

Técnico em Design de Embalagens

Técnico em Design de Interiores

Técnico em Design de Joias

Técnico em Design de Móveis

Técnico em Documentação Musical

Técnico em Fabricação de Instrumentos Musicais

Técnico em Figurino Cênico

Técnico em Instrumento Musical* 
Técnico em Modelagem do Vestuário

Técnico em Multimídia

Técnico em Museologia

Técnico em Paisagismo

Técnico em Processos Fonográficos

Técnico em Processos Fotográficos

Técnico em Produção de Áudio e Vídeo

Técnico em Produção de Moda

Técnico em Publicidade

Técnico em Rádio e Televisão

Técnico em Regência

Técnico em Teatro

PRODUÇÃO INDUSTRIAL

Técnico em Açúcar e Álcool

Técnico em Análises Químicas

Técnico em Biocombustíveis

Técnico em Biotecnologia

Técnico em Calçados

Técnico em Celulose e Papel

Técnico em Cerâmica

Técnico em Construção Naval

Técnico em Curtimento

Técnico em Fabricação Mecânica*

Técnico em Impressão offset

Técnico em Impressão Rotográfica e Flexográfica

Técnico em Joalheria

Técnico em Móveis

Técnico em Petróleo e Gás

Técnico em Petroquímica

Técnico em Plásticos

Técnico em Pré-Impressão Gráfica

Técnico em Processos Gráficos

Técnico em Química

Técnico em Têxtil

Técnico em Vestuário

\section{RECURSOS NATURAIS}

Técnico em Agricultura

Técnico em Agroecologia

Técnico em Agronegócio

Técnico em Agropecuária

Técnico em Aquicultura

Técnico em Cafeicultura

Técnico em Equipamentos Pesqueiros

Técnico em Florestas

Técnico em Fruticultura

Técnico em Geologia 
Técnico em Grãos

Técnico em Mineração

Técnico em Pesca

Técnico em Pós-Colheita

Técnico em Recursos Minerais

Técnico em Recursos Pesqueiros

Técnico em Zootecnia

\section{SEGURANÇA}

Técnico em Defesa Civil

Técnico em Segurança do Trabalho

TURISMO, HOSPITALIDADE E LAZER

Técnico em Agenciamento de Viagem

Técnico em Cozinha*

Técnico em Eventos*

Técnico em Guia de Turismo

Técnico em Hospedagem

Técnico em Lazer

Técnico em Restaurante e Bar 